João Renato Carvalho Muniz

\title{
Estrutura Tridimensional da Bothropasina, uma Metaloprotease/Desintegrina do Veneno de Bothrops jararaca.
}




\section{Estrutura Tridimensional da Bothropasina, uma Metaloprotease/Desintegrina do Veneno de Bothrops jararaca.}

Tese apresentada ao programa de pós-graduação do Instituto de Física de São Carlos, da Universidade de São Paulo, para obtenção do título de Doutor em Física Aplicada - área de concentração: Física Biomolecular.

Orientadora: Profa. Dra. Dulce Helena Ferreira de Souza.

DOUTORADO EM CIÊNCIA - FÍSICA APLICADA

INSTITUTO DE FÍSICA DE SÃO CARLOS

UNIVERSIDADE DE SÃO PAULO

São Carlos - SP

Agosto / 2007 


\begin{abstract}
AUTORIZO A REPRODUÇÃO E DIVULGAÇÃO TOTAL OU PARCIAL DESTE TRABALHO, POR QUALQUER MEIO CONVENCIONAL OU ELETRÔNICO, PARA FINS DE ESTUDO E PESQUISA, DESDE QUE CITADA A FONTE.
\end{abstract}

Muniz, João Renato Carvalho

Estrutura tridimensional da Bothropasina, uma metaloprotease/desintegrina do veneno de Bothrops jararaca./João Renato Carvalho Muniz; orientadora Dulce Helena Ferreira de Souza.São Carlos, 2007. $153 \mathrm{f}$.

Tese (Doutorado - Área de concentração: Física Aplicada Opção: Física Biomolecular) - Instituto de Física de São Carlos da Universidade de São Paulo.

1. Metaloprotease. 2. Desintegrina. 3. Cristalografia de proteínas. 4.Bothropasina. 5. Veneno de serpentes. I. Título. 


\section{FOLHA LE APROVAÇẢO}

\section{João Renato Carvalho Muniz}

Tese apresentada ao Instituto de Fisica de São Carlos da Universidade de São Paulo para obtenção do título de Doutor em Ciências.

Area de Comcentraçäo: Fisice AplicadaOpçẫo: Física siomoiecular

Aprovado em: $2 i / 09 / 2007$

Comissão Juigadora

Profá. Dra. Dulce Helena Ferreira de Souza

Instituição: UFSCar

Assinatura

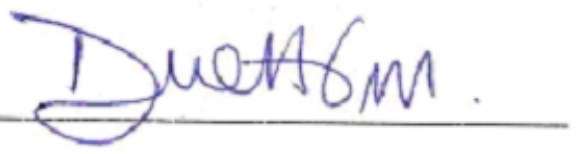

Prof. Dr. Richard Charles Garratt

Instituiçãc: Ir SC/USF:

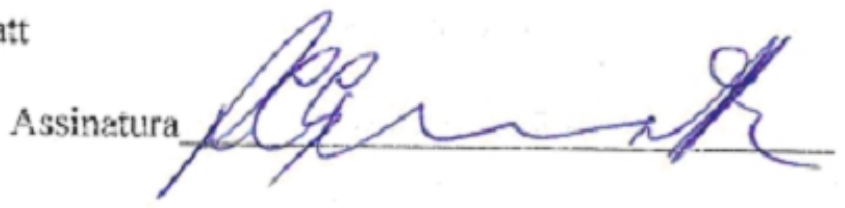

Prof. Dr. Otávio Henrique Thiemann

Instituição: IFSC/USP

Assinatura

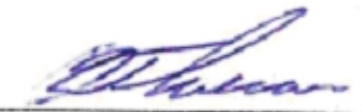

Prof. Dr. Marcos Roberto de Mattos Fontes

Instituição: UNESP

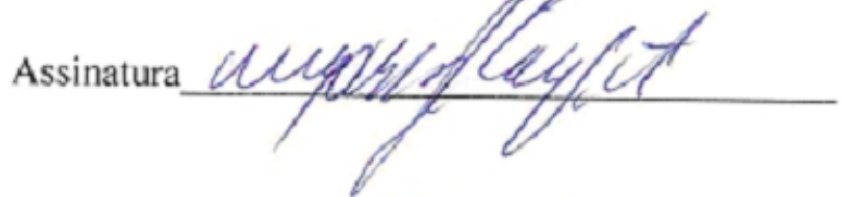

Dra. Beatriz Gomes Guimarães

Instituiç̧̃o: LNLS

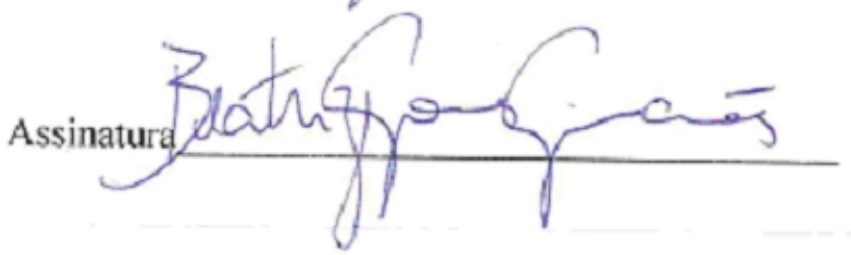




\section{DEDICATÓRIA}

Ao meu pai, Wilson Renato Muniz. À minha mãe, Maria Lúcia P. C. Muniz. À minha tia, Maria Eugênia P. Carvalho. Às minhas irmãs, Marília e Luciana. 


\section{AGRADECIMENTOS}

À Profa. Dra Dulce Helena Ferreira de Souza, pela orientação, compreensão, amizade, ricos ensinamentos, apoio, ajuda, paciência, liberdade de trabalho, respeito... Obrigado pela oportunidade que me foi dada e também por confiar esse projeto a mim.

Aos professores Richard C. Garratt, Glaucius Oliva, Otavio H. Thiemann, Adriano A., Eduardo Castellano, Igor Polikarpov e Heloísa Araújo (UFSCar) pelas discussões, dicas, apoio e incentivos imprescindíveis para grande parte das minhas realizações. Além da excelente convivência.

A TODOS os colegas e amigos (todos mesmo!) do grupo de cristalografia e de biofísica do IFSC, pelo companheirismo, atenção e sempre prestativos para boas conversas e ensinamentos, garantindo assim, um convívio alegre e hospitaleiro em todos os congressos, workshops, viagens, cursos, festas e churrascos. Grandes amigos e colegas que levarei para sempre...

Aos sempre companheiros "das antigas": Wânius, Caqui, Castilho, Ney, Alécio, Diet, PH, Fredi, Artur, Sandrinha, Sandra K., Stefano, Bianca, Fábio, Portuga, Márcio Silva, Hamilton, Humberto, Susana, Celina, Marião, Marcão, Peninha, Zé Ricardo, Alexandre BB, Ricardo A., Adriana, Sauli, Elisandra, Augustão, Gê, ...

Aos companheiros nem tão "antigos": Amanda, Nico, Nádia, Napo, Alexandre C, Carols (F, C e H), Alessandro, Lucas B, Dani T., Dani C., Ana Letícia, Lívias (S. e M.), Renata, Maria, Tavinho, Sonoda, Tiagão, Mário, Leo, Alexander, Fernando B., Mamé, Jaque, Aline, Nathalia, Aderson, ...

Ao sempre prestativo amigo Andre Ambrósio, por toda ajuda, dicas, amizade e mão na massa!!!

A TODOS os meus colegas e amigos "EXTRA" cristalografia. 
Aos funcionários do Instituto de Física de São Carlos. Em especial, gostaria de agradecer à Cristiane Gomes Lazarini Estella e Wladerez Aparecida Gounella Caiado do Serviço de Pós-Graduação do Instituto de Física de São Carlos, por toda a atenção, coleguismo, apoio e incentivo. Gostaria de agradecer também à Samira Napolitano e Beth. Todas sempre prestativas e MUITO pacientes comigo!

Ao funcionário do CBME Fernando Falvo pelo coleguismo, por toda ajuda na compra de materiais de consumo, auxílios financeiros para viagens, posteres, boa vontade em ajudar e toda a paciência que demonstra ter.

Gostaria muito de agradecer ao Prof. Sir Tom Blundell, por ter me acolhido em seu Departamento na Universidade de Cambridge durante inesquecíveis 7 meses. Ao Dr. Rinaldo Wander Montalvão e sua esposa Elisângela por todo apoio, ajuda, coleguismo, companheirismo e dicas de sobrevivência tanto em Cambridge, como na Inglaterra em geral ;). Aos colegas Vassily Bavro, Tammy, Tammy C, Dr. Dima Chirgadze, Dr. Nicholas Furnham, Dra. Eva Maria Priego, Dave, Wataro, Swannand, Vitor (e sua esposa) e Cris pelo companheirismo na hora de tomar mais um pint! (nunca half pint!).

Ao Prof. Randy Read e Dra. Airle McCoy (ambos do $M R C$ - Cambridge), pelos ensinamentos e dicas imprescindíveis para o faseamento e construção do modelo cristalográfico da bothropasina.

À CAPES por todo o suporte que me foi dado para a realização do meu doutorado e também no Programa de Desenvolvimento de Estágio no Exterior (PDEE).

A todas as pessoas que de maneira direta ou indireta contribuíram para o andamento desse trabalho.

E à você que está lendo essa tese (ou pelo menos os agradecimentos!). Meu mais sincero MUITO OBRIGADO!!!

Me desculpe se esqueci seu nome... juro que não foi intencional! 


\section{ÍNDICE}

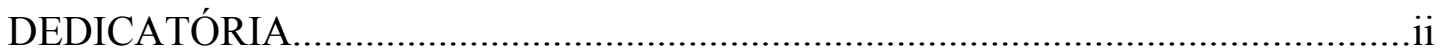

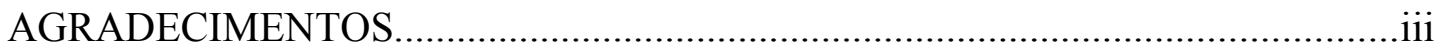

LISTA DE FIGURAS......................................................................................

LISTA DE TABELAS........................................................................................

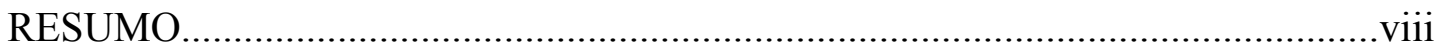

ABSTRACT

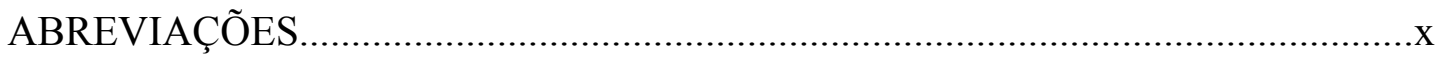

CAPÍTULO 1 - Introdução.............................................................................................1

1.1 - A serpente Bothrops jararaca...................................................................

1.2 - Envenenamento e quadro clínico.....................................................................

1.3 - Integrinas e desintegrinas.............................................................................

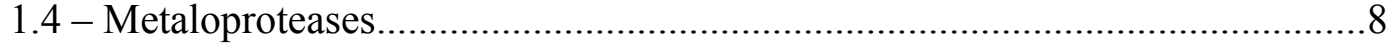

1.5 - Proteínas humanas homólogas as P-III SVMPs.............................................11

1.6 - Jararagina e Bothropasina..........................................................................13

1.6.1 - Os domínios estruturais das moléculas de jararagina e bothropasina...15

1.6.2 - Atividades biológicas da jararagina.....................................................16

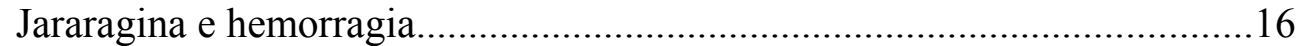

Efeitos da jararagina nos fatores de coagulação...............................................17

Efeito da jararagina nas plaquetas..............................................................18

Interação com outros tipos de células...........................................................19

Atividade pró-inflamatória induzida pela jararagina......................................20

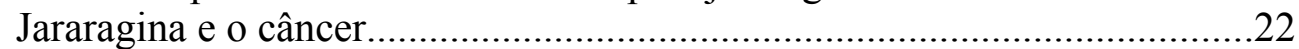

Anticorpos e inibidores da jararagina.......................................................22

1.7 - Contextualização do projeto desenvolvido.....................................................24

CAPÍTULO 2 - Objetivos.......................................................................................26

CAPÍTULO 3 - Purificação, Cristalização e Refinamento da bothropasina.......27

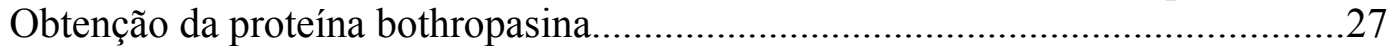

Obtenção da bothropasina sob forma cristalina...................................................30

Coleta de dados de difração...................................................................................

Faseamento e construção do modelo cristalográfico...................................................33

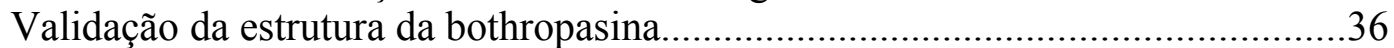

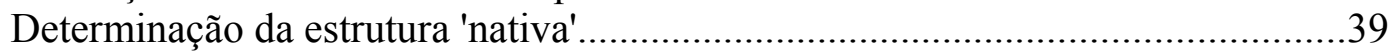

CAPÍTULO 4 - Análise Estrutural da Bothropasina e Discussões..........................41

Descrição do modelo cristalográfico.....................................................................41

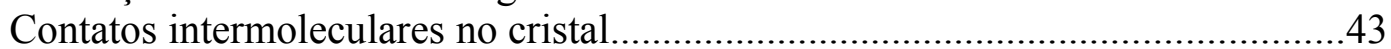

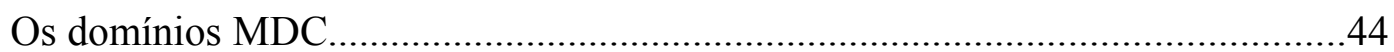

O domínio M: sítio ativo, sítio de ligação do inibidor, cálcio e açúcar...................46

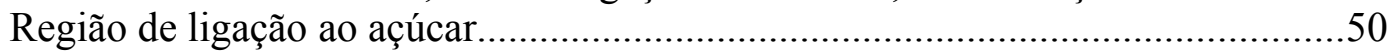

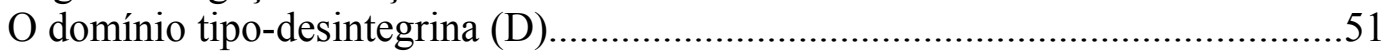

O domínio rico em cisteína (C) ........................................................................5

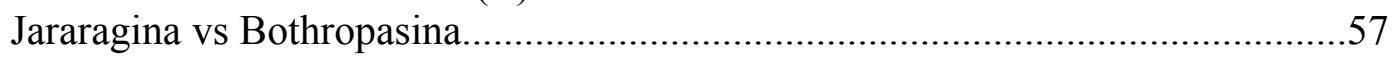


Comparação estrutural com outras P-III SVMPs.

Análise seqüencial comparativa entre bothropasina e outras P-III SVMPs.

CAPÍTULO 5 - Conclusões e Perspectivas................................................................71

CAPÍTULO 6 - Considerações Finais.................................................................76

REFERÊNCIAS BIBLIOGRÁFICAS........................................................79

APÊNDICE I - Relatório Final - PDEE.........................................................88

APÊNDICE II - Artigos Publicados em Revistas Indexadas................................101 


\section{LISTA DE FIGURAS}

Figura 1.1: Principais áreas de incidência de serpentes da espécie Bothrops jararaca na América do Sul.

Figura 1.2: Classificação de metaloproteases de venenos de serpentes (SVMPs)....10

Figura 1.3: Alinhamento entre as seqüências da jararagina e bothropasina..............15

Figura 3.1: Purificação da bothropasina.............................................................29

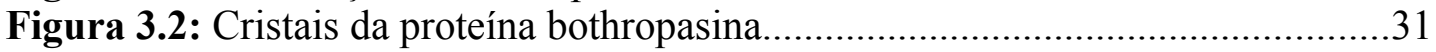

Figura 3.3: Padrão de difração do cristal de bothropasina......................................32

Figura 3.4: Valores de Rfree para estruturas depositadas no PDB em função da

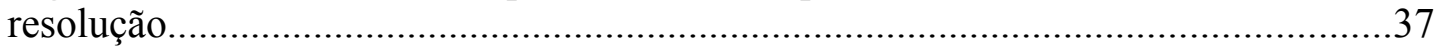

Figura 3.5: Diagrama de Ramachandran do modelo cristalográfico final..................37

Figura 3.6: Estatísticas geradas pelo programa PROCHECK.................................38

Figura 4.1: Composição da unidade assimétrica da célula unitária...........................42

Figura 4.2: Contatos intermoleculares do cristal......................................................44

Figura 4.3: Estrutura da bothropasina complexada com o inibidor POL647...........45

Figura 4.4: Domínio catalítico e seu subdomínio...............................................47

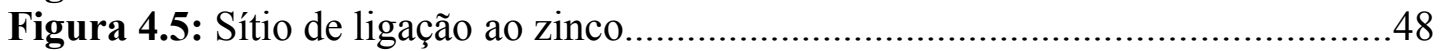

Figura 4.6: Sítio I de ligação ao cálcio do domínio M............................................49

Figura 4.7: Domínio catalítico evidenciando a cisteína livre $189 \ldots \ldots \ldots \ldots \ldots \ldots \ldots \ldots \ldots . . . .50$

Figura 4.8: Molécula de NAG presente na estrutura cristalográfica.......................51

Figura 4.9: A estrutura do domínio tipo-desintegrina (D)...................................53

Figura 4.10: Pontes dissulfeto no domínio rico em cisteína....................................55

Figura 4.11: Distribuição das pontes dissulfeto por toda a estrutura da bothropasina.

Figura 4.12: Seqüência de aminoácidos da bothropasina mostrando os padrões de pontes dissulfeto para os domínios M, D e C respectivamente..................................57

Figura 4.13: A densidade eletrônica e os verdadeiros resíduos.................................58

Figura 4.14: Mobilidade dos domínios D e C em diferentes P-III SVMPs...............60

Figura 4.15: Val215 e Leu220 como moduladores da movimentação estrutural......61

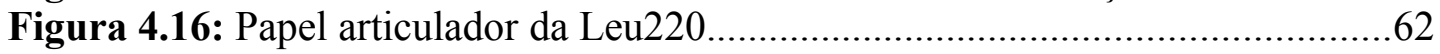

Figura 4.17: Alinhamento seqüencial de P-III SVMPs..........................................66

Figura 4.18: Árvore filogenética de P-III SVMPs.................................................67

Figura 4.19: Alinhamentos de SVMPs em grupos I e II.......................................68

\section{LISTA DE TABELAS}

Tabela 3.1: Parâmetros e estatísticas da coleta e processamento dos dados de difração de raios X para a proteína na presença de $\mathrm{NaI}$ (cristais crescidos a 4oC)....33 Tabela 3.2: Parâmetros e estatísticas da coleta e processamento dos dados de difração de raios X para a proteína 'nativa' (cristais crescidos a 4oC). 


\section{RESUMO}

A bothropasina é uma proteína hemorrágica de $48 \mathrm{kDa}$, pertencente à classe P-III das metaloproteases, isolada a partir do veneno bruto da serpente brasileira Bothrops jararaca, e que possui os domínios adesivos desintegrina (D) e rico em cisteína (C). Neste trabalho, nós apresentamos a estrutura cristalográfica da bothropasina complexada ao inibidor POL647. O domínio catalítico , metaloprotease (M), pode ser dividido em dois subdomínios, dispostos de maneira muito similar aos descritos para essa família de metaloproteases de venenos de serpentes (em inglês "SVMPs"), que inclui os sítios de ligação ao zinco e ao cálcio. A cisteína livre, resíduo Cys189, está localizado em um núcleo hidrofóbico e, sendo assim, impossibilitado de fazer pontes dissulfeto ou qualquer outra interação. O domínio D não apresenta estruturas secundárias bem definidas, sendo constituído, majoritariamente, por estruturas desordenadas como "loops", porém estabilizados por 7 pontes dissulfeto e por dois íons cálcio. A região do motivo ECD está localizada em um "loop" e é estruturalmente relacionado à região RGD das desintegrinas-RGD, derivadas de SVMPs da classe P-II. O motivo ECD é estabilizado pela ponte dissulfeto Cys277Cys310 (entre os domínios D e C), além de um íon cálcio. A cadeia lateral do Glu276 do motivo ECD está exposta ao solvente. Na bothropasina, a região hiper variada (em inglês HVR), descrita para outras P-III de SVMPs, presente no domínio $\mathrm{C}$, de fato, é bastante conservada quando comparada a outros membros da classe PIII de diversas espécies. Nós propomos que esse subgrupo deva ser referido como PIII-HCR (região altamente conservada) SVMPs. Ainda é proposto que as diferenças estruturais dos domínios D, C ou DC possam estar envolvidas em uma melhor adaptação da estrutura na interação com diferentes alvos, além do reconhecimento e especificidade a um substrato para o domínio $\mathrm{M}$. 


\begin{abstract}
Bothropasin is a $48 \mathrm{kDa}$ hemorrhagic P-III metalloprotease isolated from the venom of the Brazilian snake Bothrops jararaca, which has the disintegrin (D) and cysteinerich (C) adhesive domains. We present the crystal structure of the bothropasin complexed with the inhibitor POL647. The catalytic domain, metalloprotease (M), consists of two subdomains in a very similar scaffold to the ones described for other snake venom metalloproteases (SVMPs) including the zinc and calcium binding sites. The free cysteine, residue Cys189, is in a hydrophobic core and it is not available for disulfide bonding or other interactions. The $\mathrm{D}$ domain does not have a defined secondary structure, but instead is composed by mostly loops stabilized by seven disulfide bonds and by two calcium ions. The ECD region is in a loop and it is structurally related to the RGD region of RGD-disintegrins, which are derived from P-II SVMPs. The ECD motif is stabilized by the Cys277-Cys310 disulfide bond (between D and C domains) and by one calcium ion. The side chain of the Glu276 of the ECD motif is solvent exposed. In bothropasi, the HVR (hyper-variable region) described for other P-III SVMPs in the C domain in fact presents a well conserved sequence with respect to several other P-III members from different species. We propose that this subset be referred to as PIII-HCR (highly-conserved region) SVMPs. We further propose that the structural differences in the $\mathrm{D}, \mathrm{C}$ or $\mathrm{DC}$ domains may be involved in selecting target binding which in turn could generate substrate diversity or specificity for the $\mathrm{M}$ domain.
\end{abstract}




\section{ABREVIAÇÕES}

$\alpha 2-\mathrm{PI}-\alpha 2-$ Plasmin Inhibitor

ADAMs - A Disintegrin And Metalloprotease

ADP - Adenosina difosfato

ALT-C - Alternagina-C

CCP4 - Collaborative Computational Project Number 4

cDNA - Complementary DNA

DC - Desintegrina e rico em cisteína

DNA - Deoxyribonucleic acid

DMH - Dose Mínima Hemorrágica

ECD - Aminoácidos: glutamato, cisteína e aspartato

ECM - Extracelular Matrix

HCR - Highly-conserved region

HVR - Hyper-variated region

ICAM - Intercellular Adhesion Molecule

IL-1 $\beta$ - InterLeukin-1 $\beta$

IL-6 - InterLeukin-6

MADAM - Mammalian A Disintegrin And Metalloprotease

MD - Metaloprotease e desintegrina

MDC - Metaloprotease, desintegrina e rico em cisteína

MIDAS - Metal Ion Dependent Adhesion Site

MMP(s) - Mammal Metalloproteinase(s)

MPACs - Murin Peritoneal Adherent Cells

$\mathrm{MR}$ - Molecular replacement

mRNA - Messenger ribonucleic acid

NA - Número de acesso

NCBI - National center for biotechnology information

$\mathrm{NO}$ - Óxido nítrico

PA1-I - Type 1 Plasminogen Activator Inhibitor

PDB - Protein Data Bank

PEG - Poli-Etileno Glicol

pI - Ponto isoelétrico 
RGD - Aminoácidos: argininina, glicina e aspartato

RHC - Região hiper conservada

RHV - Região hiper variada

SAD - Single-wavelength Anomalous Dispersion

SDS-PAGE - Sodium Duodecyl Sulfate - Polyacrylamide Gel Electrophoresis

SM - Substituição Molecular

SVMP(s) - Snake Venom Metalloproteinase(s)

TACE - Tumor necrosis factor Alfa Converting Enzyme

TLS - Translation liberation screw

TNF- $\alpha$ - Tumor necrosis factor $\alpha$

tPA - Tissue-type Plasminogen Activator

uPA - Urokinase-type Plasminogen Activator

VCAM - Vascular Cell Adhesion Molecule

vWF - von Willebrand Factor 


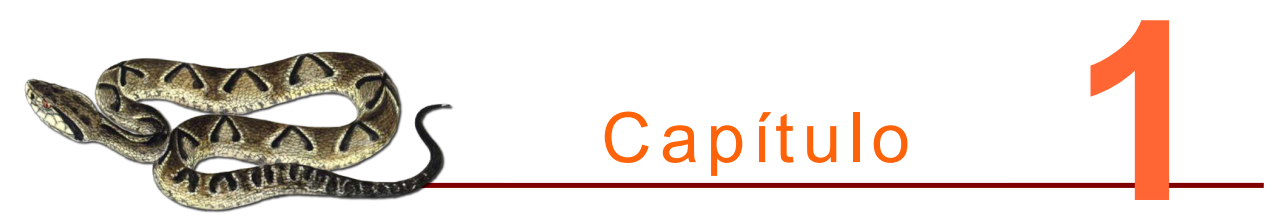

\section{INTRODUÇÃO}

\section{1 - A serpente Bothrops jararaca}

O gênero Bothrops é compreendido por 19 espécies de serpentes distribuídas por todo o território nacional. A espécie Bothrops jararaca é predominante no Brasil, sendo encontrada no sul da Bahia, Espírito Santo, Rio de Janeiro, Minas Gerais, São Paulo, Paraná, Santa Catarina e Rio Grande do Sul. Estende-se a oeste em direção ao extremo leste de Mato Grosso. No Paraguai ocorre no nordeste e na Argentina, ao norte (Hoge e Romano-Hoge 1981; Campbell e Lamar, 1989), onde é responsável por, aproximadamente, 90\% dos casos de incidentes com serpentes venenosas (Figura 1.1).

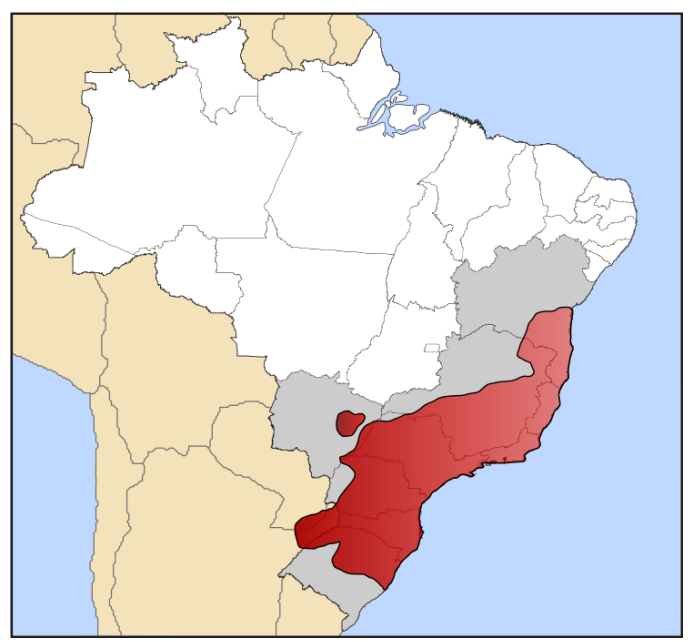

Figura 1.1: Principais áreas de incidência de serpentes da espécie Bothrops jararaca na América do Sul. Os Estados que apresentam maior índice de $B$. jararaca estão destacados na cor cinza e as regiões de maior concentração estão destacadas em vermelho. Figura adaptada de Campbell e Lamar, 1989. 


\section{2 - Envenenamento e quadro clínico}

O quadro clínico observado no envenenamento botrópico pode ser dividido em sistêmico e local (Manual de Diagnóstico e Tratamento de Acidentes por Animais Peçonhentos, 2003). As manifestações sistêmicas são caracterizadas principalmente por distúrbios na hemostasia, caracterizados por severa destruição da capacidade de coagulação sanguínea, alteração na agregação plaquetária e depleção de fibrinogênio (Hati et al.,1999). A seqüência destes eventos culmina em sangramentos de ferimentos cutâneos pré-existentes e hemorragias à como, por exemplo, a gengivorragia.

Ainda, em nível sistêmico, são observados sintomas como sudorese, hipotensão arterial e hipotermia (Cardoso, 1997). As manifestações locais são caracterizadas por dor e edema, persistentes no local da picada, de intensidade variável e, em geral, de instalação precoce e caráter progressivo.

Equimoses e hemorragias, no ponto da picada, são freqüentes e bolhas podem aparecer na evolução do quadro clínico, acompanhadas ou não de necrose (Cardoso, 1997). Nos casos mais graves, o dano tecidual pode resultar em sérias seqüelas, tais como a perda funcional ou permanente do tecido ou do membro afetado, necrose, cicatrizes permanentes e deformidades (Rosenfeld, 1971; Cardoso et al., 1993). A magnitude dos efeitos locais em envenenamentos botrópicos depende, basicamente, da quantidade de veneno inoculada, do tempo entre a picada e o início da soroterapia, do peso e idade do paciente e da região anatômica onde ocorreu a picada (França, 1997).

O tratamento utilizado, atualmente, no caso dos acidentes por $B$. jararaca é a soroterapia com antiveneno botrópico poliespecífico (Manual de Diagnóstico e Tratamento de Acidentes por Animais Peçonhentos, 2003). A 
quantidade de antiveneno administrada ao paciente varia conforme a gravidade do caso, que é classificado em leve, moderado e grave, de acordo coma as manifestações clínicas (Cardoso et al. 1993). Este tratamento mostra-se eficiente em neutralizar os efeitos sistêmicos observados, porém pouca neutralização é observada sobre os efeitos locais (Gutíerrez et al., 1981). Dado o rápido desenvolvimento da lesão local, é extremamente difícil a sua completa neutralização por antivenenos, pois, freqüentemente, ocorre uma demora no início da aplicação da soroterapia. Como na maioria dos acidentes ofídicos no Brasil o início do tratamento ocorre em um tempo médio de quatro horas após a picada, o quadro inflamatório local já se instalou e a soroterapia pouco contribui para revertê-lo. Em modelos experimentais, observa-se que a administração do antiveneno botrópico, 15 a 30 minutos após a inoculação do veneno de Bothrops asper em camundongos também não se mostra eficiente na neutralização dos efeitos locais (hemorragia, edema e mionecrose), sendo parcialmente eficiente apenas quando o antiveneno é administrado imediatamente após a inoculação do veneno (Gutíerrez et al., 1981). Entretanto, não se observa uma completa neutralização dos efeitos locais, mesmo quando o veneno botrópico é inoculado em animais experimentais, logo após a administração do antiveneno homólogo, ainda que este apresente alto título de anticorpos capazes de neutralizar as principais atividades do veneno botrópico in vitro (Otero et al., 1997).

\section{3 - Integrinas e desintegrinas}

Integrinas são receptores extracelulares da matriz extracelular em animais e são glicoproteínas estruturadas como heterodímeros de duas cadeias ( $\alpha$ e $\beta$ ) associados de forma não covalente. Baseando-se na similaridade seqüencial, o sistema de nomenclatura proposto para a designação das integrinas categoriza as subunidades individuais de cada heterodímero como $\alpha$ (120 a $180 \mathrm{kDa})$ e $\beta$ (90 a 110 
$\mathrm{kDa}$ ), ambas do tipo transmembrânicas, cujas combinações definem as propriedades adesiva e de sinalização.

A maior parte da molécula de integrinas se encontra exposta ao meio extracelular, enquanto que o citoesqueleto de actina e o maquinário de sinalização estão associados a um pequeno domínio citoplasmático (Dzamba et al., 2001). Em mamíferos é constatada a existência de, ao menos, 18 subunidades $\alpha$ e $\beta$, que, combinando-se entre si, garantem a grande diversidade de integrinas e suas diferenças de ligantes, afinidades e atividades biológicas (Marcinkiewicz et al., 1999; Parise et al., 2000; Cairns et al., 2003). Os domínios extracelulares das subunidades $\beta$ apresentam 56 resíduos de cisteínas, a maioria dos quais se localiza dentro de um agrupamento de 260 aminoácidos, separados da membrana plasmática por, aproximadamente, 50 resíduos. As subunidades $\alpha$ contêm 7 seqüências repetitivas de, aproximadamente, 60 resíduos constituintes de motivos "EF Hand", com seqüência consenso "DxDxDGxxD", capazes de atrair cátions divalentes como $\mathrm{Ca}^{2+}$, $\mathrm{Mg}^{2+}$ e $\mathrm{Mn}^{2+}$. Estes motivos são importantes para manter a capacidade de adesão da integrina $\mathrm{e}$ as mudanças conformacionais que afetam o receptor pelo ligante (Dzamba et al., 2001).

O termo integrina foi, inicialmente, utilizado, referindo-se ao papel de intermediador na comunicação entre o citoesqueleto celular e proteínas plasmáticas ou da matriz extra celular (ECM), por exemplo, laminina, fibrinogênio, fibronectina, colágeno, vitronectina, osteopontina, trombospondina e iC3b do sistema complemento. No entanto, essas proteínas de superfície celular também mediam a adesão célula-célula através de interações com outras proteínas de membrana como ICAM-1, 2 e 3, VCAM-1 e caderina E (Darribere et al., 2000; Clegg et al., 2003; Jin e Varner, 2004). 
O principal determinante da especificidade da interação entre os ligantes é a composição das subunidades $\alpha$ e $\beta$ de cada tipo de molécula. Muitas das integrinas possuem capacidade de reconhecimento da seqüência RGD em seus ligantes. Entretanto, essa característica não garante que proteínas, com essa seqüência, possam ser reconhecidas por um mesmo receptor, o que leva a considerar a probabilidade de que sejam seqüências vizinhas ao RGD e as diferentes conformações tanto dos sítios adesivos, como dos rearranjos conformacionais que definem tal especificidade (Dzamba et al., 2001).

Ao se associarem a ligantes endógenos ou não, as integrinas dão início a um processo com diferentes estados de ativação, sendo definido como a troca na afinidade por seu ligante por um receptor individual. O processo regulatório, capaz de modificar a afinidade, se define como Modulação da Afinidade, que é disparado através de um sistema de sinais do tipo "inside out", sendo então uma forma rápida para regular as funções adesivas em resposta a vários estímulos fisiológicos (Dzamba et al., 2001). Entre os mecanismos envolvidos na regulação da interação com o ligante encontram-se íons metálicos, como sugerido pela presença dos motivos “ $E F$ hand" e MIDAS (Metal Ion Dependent Adhesion Site), os quais podem modular positiva ou negativamente. Por exemplo, o $\mathrm{Mn}^{2+}$ induz ao aumento da afinidade do receptor por seu ligante, enquanto que o $\mathrm{Ca}^{2+}$ estabiliza conformações de baixa afinidade. Além do mais, são considerados os fenômenos "clustering" ou agrupamento de receptores como outra forma de aumentar a afinidade por seu ligante, o qual é independente do estado de ativação do receptor mediado por mudanças conformacionais. Neste modelo, a presença de ligantes multivalentes ou a associação de receptores ao citoesqueleto podem limitar a difusão das moléculas pela membrana, aumentando, desta maneira, a força adesiva da interação (Kim et al., 
2003).

As funções das integrinas como mediadoras de adesão e fusão celular (célula-célula e célula-matriz), pela ativação e inibição de sinais, se resumem em dois tipos de sistemas de sinalização: (1) a origem é a própria célula portadora da integrina em sua parte exterior e (2) proveniente do meio externo para a célula, modulando assim sua função. O primeiro sistema é conhecido como sinalização "inside-out", enquanto que o segundo é conhecido como sinalização "outside-in". Na sinalização "inside-out", o aumento de afinidade dos receptores, por mudanças conformacionais, é mediado pela ativação prévia de sistemas de sinalizações intracelulares próprios. Desta maneira, constitui-se uma sinalização bidirecional entre o ambiente extra e intracelular (Coppolino e Dedhar, 2000). Os eventos decorrentes da transdução de sinais a partir de integrinas são complexos e, até o momento, não foram completamente elucidados.

As cascatas de sinalizações, possíveis de serem disparadas por integrinas, podem ser moduladas, também, por proteínas de membrana como receptores de fatores de crescimento (Eliceiri, 2001; Ross, 2004), receptores de sobrevivência (Hanahan e Weinberg, 2000), receptores que se ligam à região constante de imunoglobulinas (Ortiz-Stern e Rosales, 2003), proteínas transmembrânicas (TM4SF, Woods e Couchman, 2000), receptor de ativador de plasminogênio tipo uroquinase (uPA, CD87; Xue et al., 1997) e pela proteína associada a integrina (IAP, CD47; Lindberg et al., 1996).

Como pode ser visto, as integrinas estão presentes em numerosos processos fisiológicos onde se faz vital o contato direto entre as células participantes, servindo não apenas como molécula ponte em interações intercelulares, mas também como molécula ponte entre a matriz extracelular e o citoesqueleto da célula, através 
da troca de sinais celulares. Em decorrência dessas atividades, as integrinas não estão associadas somente a processos fisiológicos, mas também a processos patológicos como a neoplasia, a metástase, a disfunção imune, as infecções virais, a osteoporose e a coagulopatia (Arnaout, 1990; Hynes, 1992).

A ligação reversível célula-matriz extracelular, mediada por integrina, pode ser interrompida por pequenos peptídeos chamados desintegrinas. O termo desintegrina foi utilizado, pela primeira vez, em 1989, para descrever um grupo de moléculas de baixa massa molecular $(5-9 \mathrm{kDa})$, ricas em cisteínas, derivadas de venenos de serpentes, os quais interagiam com receptores da superfície das células (integrinas) (Dennis et al., 1989; Gould et al., 1990; Niewiarowisk et al., 1994; Maclane et al., 1998; Huang, 1998). Desintegrinas são potentes inibidores da agregação plaquetária por se ligarem especificamente ao receptor de fibrinogênio, à glicoproteína IIb/IIIa $\left(\alpha_{\mathrm{II}} \beta_{3}\right)$ de membrana de plaquetas, através da sua seqüência adesiva RGD. O domínio desintegrina apresenta uma grande diversidade estrutural e funcional. As desintegrinas, derivadas das metaloproteases de venenos de serpentes (SVMPs - Snake Venom Metalloproteinases) da classe P-II, são normalmente pequenas e geralmente contêm a seqüência adesiva RGD (Huang e Niewiarowski, 1994). Estudos demonstraram que desintegrinas, contendo a seqüência RGD, são capazes de inibir a adesão de células tumorais à matriz extracelular por competição específica pelos receptores de integrinas (Trikha et al., 1994; Chiang et al., 1994; Sheu et al., 1997).

Proteínas que não apresentam o motivo RGD, mas que apresentam atividade de inibição de ligação de ligantes a integrinas, são encontradas em venenos de serpentes. São as metaloproteinases/desintegrinas ou tipo-desintegrinas, descritas no próximo item. 


\section{4 - Metaloproteases}

As serpentes são as mais prodigiosas fontes de toxinas que podem chegar a ser úteis à humanidade. Seus venenos são compostos por complexas mesclas de polipeptídeos e proteínas que induzem a uma variedade de efeitos farmacológicos, os quais provêem uma útil ferramenta para a compreensão de muitos eventos moleculares dentro dos processos fisiológicos normais. Os principais componentes encontrados em venenos de serpentes são lectinas, metaloproteinases, serinoproteinases, desintegrinas, fosfolipases e peptídeos que agem sobre a bradicinina e o sistema angiotensina. Além de proteínas, o veneno de serpentes também é caracterizado por uma rica mistura de compostos orgânicos e inorgânicos que variam de acordo com a espécie de serpente. Os mais abundantes compostos inorgânicos são o cálcio, cobre, ferro, potássio, magnésio, manganês, sódio, fósforo, cobalto e zinco. A função desses compostos está relacionada a mecanismos catalíticos de certos componentes enzimáticos presentes no veneno (Bjarnason e Fox, 1994). Em estudos proteômicos recentes, mais de 200 peptídeos foram revelados por eletroforese bi-dimensional do veneno de $B$. jararaca, confirmando, assim, a complexa natureza do veneno (Fox et al., 2002).

Um grupo importante de enzimas proteolíticas, encontradas nos venenos, é formado pelas metaloproteases (SVMPs).

As metaloproteases compreendem uma série de enzimas geralmente dependentes de zinco, também chamadas de zinco-metaloproteases, com variada massa molecular e responsáveis pelo efeito hemorrágico característico destes envenenamentos (Bjarnason e Fox, 1994). As metaloproteases são divididas de acordo com a estrutura primária de seus sítios catalíticos e incluem os grupos das zincinas (subdivididas em gluzincinas ou metzincinas, dependendo do quarto resíduo 
responsável pela coordenação do íon $\mathrm{Zn}$, que pode ser um glutamato ou histidina, respectivamente), inverzincinas, carboxipeptidades e DD carboxipeptidases. Este último grupo ainda é subdividido em astacinas (encontradas em crustáceos), serralisinas (bactérias), matrixinas (metaloproteases presentes na matriz extracelular de mamíferos) e reprolisinas (venenos de serpentes) (Bode et al., 1993; Hooper, 1994).

As metaloproteases hemorrágicas de venenos são classificadas, de acordo com sua massa molecular, em pequenas (22-27 kDa), médias (33-48 kDa) e grandes (50-65 kDa), segundo Bjarnason e Fox (1994).

As SVMPs são produzidas na glândula de veneno como pré-pró-domínio, na forma de precursores inativos ou zimogênios, nos quais o mecanismo de “cysteine-switch" inibe sua atividade enzimática (Grams et al., 1993; Gutiérrez et al., 2000). O peptídeo sinal das SVMPs possui, aproximadamente, 18 aminoácidos altamente conservados, os quais servem como seqüência-sinal para determinar sua localização sub celular ou secreção (Sha et al., 1997). Os zimogênios são processados proteoliticamente para serem ativados. Seu domínio de ligação ao $\mathrm{Zn}^{2+}$ é tetraédrico, com seqüência de aminoácidos HExGHNLGxxHD com 3 His coordenando o $\mathrm{Zn}^{2+}$ e uma molécula de água (Jia et al., 1996). Entretanto, na presença de ligantes inibidores, o zinco também pode apresentar uma coordenação pentaédrica, através dos oxigênios do grupo carbonil desse ligante. A cadeia lateral da metionina do motivo "Met-turn" fornece uma base hidrofóbica abaixo das cadeias laterais das histidinas que coordenam o zinco (Bode et al., 1993). O domínio catalítico ainda conta com um íon de cálcio localizado sobre a superfície da molécula, do lado oposto ao catalítico, importante na conformação estrutural.

Desde o ponto de vista genético, verifica-se que as SVMPs se encontram 
codificadas por quatro classes de DNA: classe nucleotídica I ou N-I, que codifica para domínios pró e metaloprotease, classe N-II que codifica para domínios pró, metaloprotease e desintegrina e classe N-III, que codifica para domínios pró, metaloprotease, tipo-desintegrina e rico em cisteína localizado na extremidade carbóxi-terminal do domínio desintegrina e a última classe, a N-IV, que codifica para um domínio tipo lectina, na extremidade carbóxi-terminal da proteína (Wolfsberg et al., 1995; McLane et al., 1998; Yamamoto et al., 1999).

Com base em seus domínios estruturais, as metaloproteinases, quando isoladas do veneno bruto, podem ser classificadas em 4 classes distintas: P-I, P-II, PIII ou P-IV, de acordo com a presença de domínios adicionais na região carbóxiterminal do domínio metaloprotease (Bjarnason e Fox, 1994; Hite et al., 1994) (figura 1.2). Assim, após o processamento, proteínas da classe P-I encontram-se somente com o domínio catalítico, as da classe P-II com domínios catalítico e desintegrina (contendo o motivo RGD), as da classe P-III com domínios catalítico, tipo-desintegrina e rico em cisteína, e proteínas da classe P-IV com a adição do domínio lectina na porção C-terminal do domínio rico em cisteína.

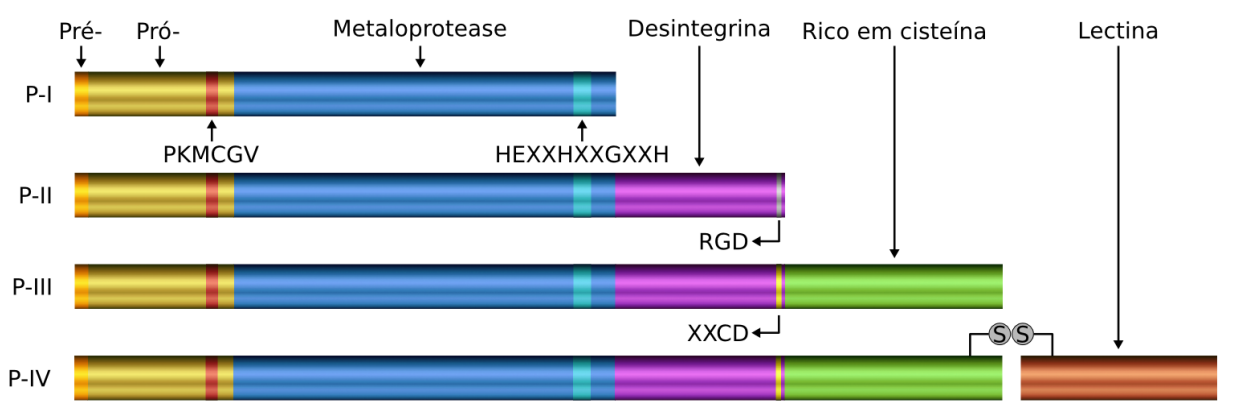

Figura 1.2: Classificação de metaloproteases de venenos de serpentes (SVMPs). A região altamente conservada "PKMCGV" no Pró-domínio, assim como o sítio de coordenação do zinco "HEXXHXXGXXH" estão em destaque. A ponte dissulfeto, que liga o domínio lectina ao rico em cisteína em metaloproteases da classe P-IV, está representada por dois "S" circunscritos. Diagrama adaptado de Bjarnason e Fox, 1994. 
As metaloproteinases de venenos de serpentes (SVMPs), pertencentes à classe P-III, são denominadas tipo-desintegrina (não-RGD) por apresentarem o motivo E/DCD, substituindo o motivo RGD. Estudos têm mostrado que o motivo D/ECD está envolvido na ligação de integrinas (Myles et al., 1994) e que domínio rico em cisteína também pode estar envolvido nesta interação (Bjarnason e Fox, 1994). As metaloproteinases tipo-desintegrinas (MDC) podem sofrer processamento proteolítico, liberando o domínio catalítico (metaloprotease) e os domínios tipodesintegrina e rico em cisteína (DC). Proteínas contendo somente os domínios DC processados mostram atividades de inibição de adesão celular e de agregação plaquetária. A ALT-C, uma DC isolada do veneno de B. alternatus, é capaz de inibir a adesão de células K562 transfectadas com a integrina $\alpha 2 \beta 1$ mediada pelo colágeno tipo I (Souza et al., 2000), além de inibir a adesão de fibroblastos humanos (Cominetti et al., 2004). A Jararagina-C, uma proteína DC de $28 \mathrm{kDa}$ originada do processamento da jararagina, possui a capacidade de inibir a agregação plaquetária induzida pelo colágeno e por adenosina difosfato (ADP) (Usami et al., 1994; Jia et al., 1997; Shimokawa et al., 1997). A Jaracetina, um dímero de $60 \mathrm{kDa}$, que representa uma diferente forma processada da jararagina, interage com o domínio A do vWF e também bloqueia a adesão das plaquetas ao colágeno dependente de $\alpha 2 \beta 1$ (De Luca et al., 1995).

\section{5 - Proteínas humanas homólogas as P-III SVMPs}

Os fenômenos de adesão célula-célula, célula-matriz e a proteólise da matriz extracelular são vitais para o desenvolvimento normal de processos, como a morfogênese dos tecidos, a cicatrização de feridas, e em processos patológicos como a invasão de células tumorais e metástase (Gould et al., 1990; Wolfsberg et al., 1995). Estes fenômenos se encontram mediados por proteínas de adesão de 
superfície celular, tais com as caderinas, a superfamília das imunoglobulinas, as selectinas, integrinas e sindecanas (Gould et al., 1990). Outro grupo de proteínas envolvidas é o das moléculas ancoradas à superfície da membrana, as quais se encontram representadas pelas metaloproteases de matriz da membrana. Entre as proteases acopladas à matriz da membrana, são encontradas aquelas que contêm um domínio metaloprotease e um domínio tipo-desintegrina, codificadas pela família de genes conhecidos como ADAMs (A Disintegrin And Metalloprotease) (Wolfsberg et al., 1995). As ADAMs são, portanto, proteínas homólogas às SVMPs da classe P-III encontradas em mamíferos e outros animais e estão relacionadas a diversos processos fisiológicos como fertilização e diferenciação celular.

A estrutura básica das ADAMs está filogeneticamente bem conservada e as mudanças estruturais são produtos da adaptação necessária à sua respectiva função (Yamamoto et al., 1999). Assim, por exemplo, as ADAMs designadas desde 1 a 7 se expressam, de maneira principal, em órgãos reprodutores, enquanto que seu papel, durante a espermatogênese, é a fusão esperma-óvulo (Wolfsberg et al., 1995; Yamamoto et al., 1999; Blobel 2005), e cada uma é expressa em distintas etapas do processo espermatogênico. A ADAM 9, por sua vez, também chamada MDC9 (Metalloprotease-like, Disintegrin-like and Cysteine rich), tem sido encontrada em vários tipos de órgãos, entre os quais os pulmões e as glândulas mamárias, podendo ter relação com o desencadeamento de sinais de transdução. A ADAM 11 é encontrada em células de órgãos reprodutores e não reprodutores, enquanto que as ADAMs 12 e 19, também conhecidas como Meltrinas $\alpha$ e $\beta$ respectivamente, estão localizadas na musculatura embrionária (estágio neonatal) e tecido ósseo de embriões e adultos (Yamamoto et al., 1999). Por outro lado, Yamamoto (1999) relaciona a ADAM 17, também chamada de TACE (Tumor necrosis factor Alfa Converting 
Enzyme), e ADAM 10, também conhecida por MADAM (bovine Mammalian A Disintegrin And Metalloprotease), que cumprem funções importantes no processamento da forma acoplada à superfície celular do precursor do fator de necrose tumoral $\alpha$ (TNF- $\alpha)$, na liberação da forma madura da citocina.

Todas as proteínas pertencentes à família das ADAMs contêm um domínio do tipo metaloprotease, o qual é similar ao encontrado nas SVMPs dependentes de $\mathrm{Zn}^{2+}$. O domínio, tipo metaloprotease das ADAMs 1, 8, 9 e 10, apresenta resíduos conservados no sítio ativo, similares aos da SVMPs mantendo também sua propriedade catalítica, enquanto que, no das ADAMs 2-7 e 11, o mesmo contém seqüências diferentes em seu sítio ativo. Assim, essas proteínas, apesar da presença do domínio metaloprotease, são cataliticamente inativas (Wolfsberg et al., 1995).

\section{6 - Jararagina e Bothropasina}

Jararagina e bothropasina são duas SVMPs da classe P-III isoladas do veneno de B. jararaca, e, portanto, pertencentes à família metalopeptidase, e à subfamília reprolisina, com atividade catalítica hidrolase do tipo endopeptidase, dependentes do zinco (Bjarnason e Fox, 1994). As duas proteínas apresentam elevado grau de identidade, aproximadamente $97 \%$, o que as caracteriza como isoformas. Uma vez que o aminoácido N-terminal encontra-se bloqueado, não é possível caracterizar essas proteínas através de seqüenciamento da região N-terminal por degradação de Edman. Assim, segundo a literatura, as proteínas jararagina e bothropasina são distinguidas com base no protocolo de purificação, isto é, dependendo das colunas cromatográficas utilizadas, é isolada jararagina ou bothropasina.

A jararagina foi isolada pela primeira vez em 1992 (Paine et al., 1992) e 
caracterizada como uma metaloproteinase/desintegrina de alta massa molecular (52 kDa) da classe P-III, com 421 aminoácidos na proteína madura, após a modificação pós-traducional. Possui ação hemorrágica (Paine et al., 1992) e também a capacidade de inibir a agregação plaquetária, ao bloquear a ligação do colágeno à integrina $\alpha 2 \beta 1$ presente na membrana das plaquetas. A jararagina se liga ao domínio I da cadeia $\alpha 2$ e/ou cliva a cadeia $\beta 1$ dessa integrina (Kamiguti et al., 1996). A jararagina interfere na função plaquetária de duas maneiras distintas: (1) por degradação dos diferentes receptores plaquetários e proteínas adesivas na hemostasia; e (2) interferência não enzimática (mediada pelo domínio desintegrina) com a função de receptores da adesão plaquetária (Kamiguti et al., 1996b). Estudos recentes têm sugerido a existência de formas alternativas de jararagina secretadas pela glândula venenífera. Uma das formas é proteoliticamente estável (que se apresenta no veneno na forma da jararagina) e outra proteoliticamente instável (processada rapidamente no veneno produzindo a jararagina-C) (Moura-da-Silva et al., 2003).

A bothropasina foi isolada do veneno de $B$. jararaca pela primeira vez em 1982 (Mandelbaum et al., 1982) e caracterizada como uma proteína da classe PIII das SVMPs. Assim como a jararagina, bothropasina também é constituída por 421 resíduos de aminoácidos e apresenta atividade hemorrágica (Mandelbaum et al., 1982). Estudos recentes mostram a expressão dos domínios DC da bothropasina (Assakura et al., 2003). Devido ao fato de não ser possível o seqüenciamento do Nterminal, as seqüências conhecidas de ambas as proteínas são as deduzidas do cDNA (mostradas na figura 1.3). 


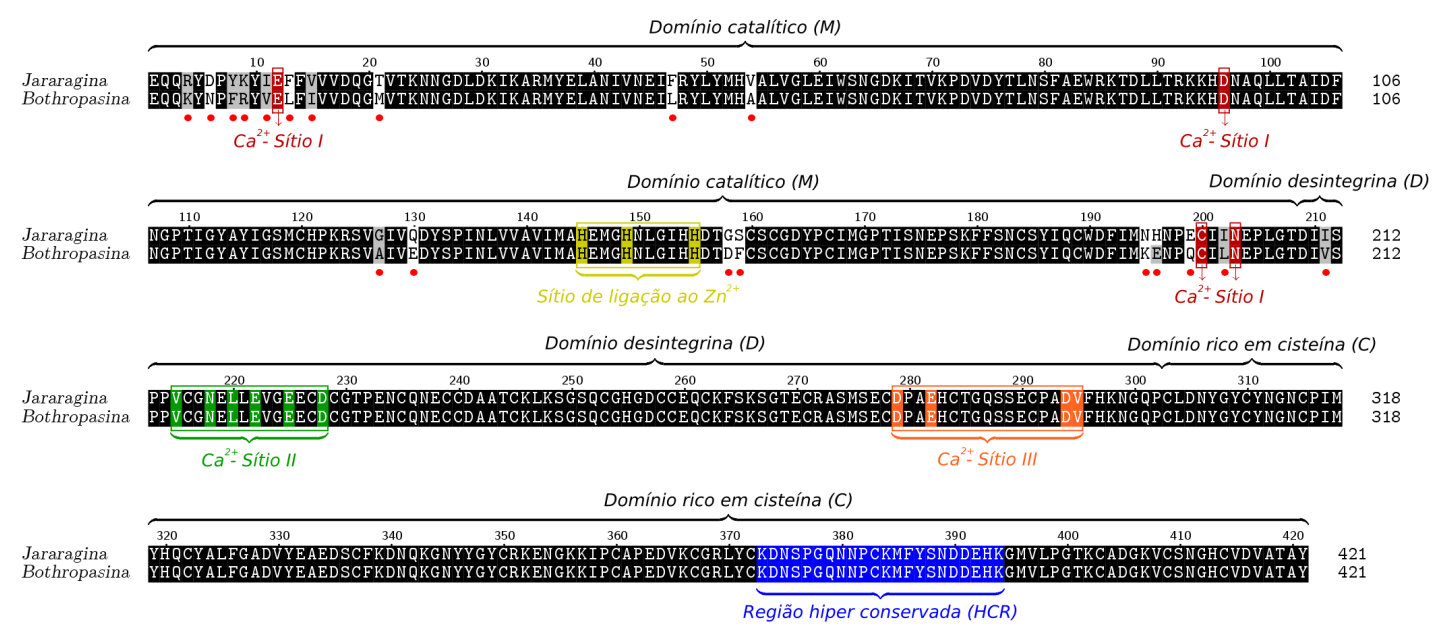

Figura 1.3: Alinhamento entre as seqüências da jararagina e bothropasina. Quando comparadas em um alinhamento seqüencial, 19 resíduos não idênticos são encontrados, todavia, 10 são similares. Seqüências deduzidas do cDNA (Número de acesso no NCBI: P30431 e AAC61986.2, respectivamente).

\subsection{1 - Os domínios estruturais das moléculas de jararagina e bothropasina}

A jararagina e a bothropasina, duas proteínas da classe P-III das metaloproteases, como visto anteriormente, são compostas por uma estrutura de multidomínios, representada esquematicamente nas figuras 1.2 e 1.3. Estes domínios são:

- Peptídeo sinal: tem como função garantir a correta localização subcelular ou secreção da proteína (Shah et al., 2000).

- Pró-domínio: região com resíduos de aminoácidos altamente conservados, que regula a atividade enzimática, através da interação entre a sulfidrila do resíduo Cys, do motivo PKMCGVTQ das SVMPs, com o íon $\mathrm{Zn}^{2+}$ presente no sítio ativo. Esta interação resulta na inativação do domínio catalítico, um mecanismo chamado de “cysteine-switch", similar ao proposto para as MMPs encontrado no precursor protéico não processado. Esta região permite que as metaloproteases sejam armazenadas na forma de zimogênios inativos, evitando, assim, sua 
autodigestão (Grams et al., 1993).

- Domínio catalítico - Metaloprotease (M): é o domínio de ligação de íons metálicos. No caso da jararagina, o íon $\mathrm{Zn}^{2+}$. Apresenta a seqüência de aminoácidos HExxHxxGxxHD, altamente conservada nessa família de enzimas e responsável pela coordenação do metal próximo à região CIMxP da volta de metionina ou "met-turn", característica das metazincinas. Nesse domínio são encontrados 7 resíduos de cisteínas.

- Domínio tipo-desintegrina (D): este domínio apresenta a seqüência ECD que está associada com a especificidade das SVMPs pelas integrinas (Zhou et al., 1995; Jia et al., 2000). Nesse domínio são encontradas 15 cisteínas.

- Domínio rico em cisteína (C): Apesar desse nome, o domínio C possui um número de Cys menor que o domínio D (13 cisteínas).

\subsection{2 - Atividades biológicas da jararagina}

\section{Jararagina e hemorragia}

Metaloproteinases de venenos de serpentes são freqüentemente responsáveis pela degradação de proteínas da matriz celular, resultando no rompimento da integridade das células endoteliais nas paredes dos vasos sanguíneos e subseqüente hemorragia potencializada pelos distúrbios das funções plaquetárias (Bjarnason e Fox, 1994; Kamiguti et al., 2003). As SVMPs afetam principalmente vasos capilares e pequenas veias (Moreira et al., 1994).

A jararagina promove a homeostase, através da degradação das proteínas responsáveis pela coagulação, como, por exemplo, os fibrinogênios (Kamiguti et al., 1994a; Markland, 1998) e pela inibição da agregação plaquetária (Kamiguti et al., 1996a). 
A hemorragia sistêmica induzida pela jararagina em ratos, parece ser dependente de sua atividade proteolítica, uma vez que sua atividade é completamente eliminada quando a jararagina é incubada com peptídeos inibidores de batimastato anteriormente à injeção (Escalante et al., 2003). Além do mais, quando o batimastato e o quelante $\mathrm{CaNa}_{2}$ EDTA são administrados por alguns minutos que antecedem o envenenamento em ratos, os compostos apresentam clara eliminação das hemorragias locais e necroses dermais (Rucavado et al., 2000). Sendo assim, pode-se constatar a importância da preservação da atividade catalítica das metaloproteases a fim de promover a quebra das proteínas de matriz, caracterizando-se como o principal mecanismo envolvido no sangramento.

\section{Efeitos da jararagina nos fatores de coagulação}

A jararagina tem como característica clivar o fibrinogênio em sua porção C-terminal da cadeia $\mathrm{A} \alpha$, resultando na remoção de um fragmento com aproximadamente $23 \mathrm{kDa}$, mas não promove nenhum efeito tanto na cadeia $\beta$, quanto na $\gamma$ (Kamiguti et al., 1994a). A restante molécula de fibrinogênio purificada permanece funcional em ambas as respostas de agregação plaquetária para o ADP, adrenalina e sua habilidade coagulante plasmática pela ativação da trombina. A única conseqüência da atividade $\alpha$-fibrinogenase da jararagina foi a anormal polimerização de fibrina pela trombina (Kamiguti et al., 1994a).

Tem-se mostrado que a jararagina aumenta a atividade fribinolítica in vitro do plasma humano e de outros animais, através do aumento da atividade do tPA (tissue-type Plasminogen Activator), pela dissociação do complexo do tPA com seu inibidor PA1-I (type 1 Plasminogen Activator Inhibitor) e pela inativação do $\alpha 2$-PI ( $\alpha 2$-Plasmin Inhibitor) no plasma (Sugiki et al., 1995). Além do mais, a ativação da uPA (urokinase-type Plasminogen Activator) foi descrita após interações in vitro 
entre o ziminogênio da uPA e jararafibrase I (Sugiki et al., 1998).

Esses efeitos possivelmente ocorrem devido à atividade catalítica da jararagina permanecer inalterada pelos inibidores de protease plasmáticos como as $\alpha_{2}$-macroglobulinas. Embora as P-I SVMPs sejam rapidamente inibidas, P-III SVMPs não apresentam inibição pelas $\alpha_{2}$-macroglobulinas, além do fato da capacidade desse inibidor em fazer ligações covalentes com a enzima (Kamiguti et al., 1994b). Os autores ainda sugerem que a resistência à inibição apresentada pelas P-III pode estar relacionada a restrições estruturais, uma vez que proteínas da classe P-III, possuem os domínios adicionais desintegrina e rico em cisteína. Esses domínios poderiam estar relacionados com interações entre SVMPs e os inibidores plasmáticos. Por outro lado, jararafibrase I é completamente inibida pelas macroglobulinas humanas e de ratos (Anai et al., 1998).

\section{Efeito da jararagina nas plaquetas}

A maioria dos estudos relacionados à ação da jararagina na hemostase envolve agregação plaquetária. Após a injúria vascular, plaquetas são ativadas pelas fibras de colágeno, mediadas pelo Fator de von Willebrand (vWF), resultando na adesão plaquetária ao subendotélio exposto. Os receptores, integrina $\alpha_{2} \beta_{1}$ e o complexo GP VI-FcR cadeia $\gamma$, possuem um papel pivotal na ativação das plaquetas pelo colágeno (Watson e Gibbins, 1998). A adesão de plaquetas é mediada pela ligação do complexo GPIb-IX-V com o vWF (Weiss et al., 1986; Atkinson et al., 2003; Pinto et al., 2007). A união desses receptores promove a ativação das plaquetas e agregação, via interação com a integrina $\alpha_{\mathrm{II}} \beta_{3}$ com os ligantes plasmáticos, proporcionando a formação de uma barreira plaquetária importante para que o sangramento cesse. 
A jararagina inibe a agregação plaquetária induzida pela ristocetina e pelo colágeno, indicando que ambos os caminhos supracitados são afetados pela ação da toxina. A inibição da agregação plaquetária induzida pela ristocetina tem sido atribuída a um efeito direto da enzima sobre o vWF e não de sua ativação no receptor GP Ib-IX-V (Kamiguti et al., 1996a; Serrano et al., 2006). A jararagina cliva a subunidade vWF na metade N-terminal da molécula, que contém o sítio de ligação para o receptor $\mathrm{GP} \mathrm{Ib}$ (o domínio $\mathrm{AI}$ ), dando origem a vários fragmentos. Além do mais, a hidrólise do vWF pela jararagina acarreta no desaparecimento das estruturas multiméricas de elevada massa molecular da proteína. A clivagem do vWF pela jararagina e, provavelmente por outras proteínas presentes no veneno de B. jararaca, contribui ao processo hemorrágico característico de pacientes com envenenamento.

A proteólise do vWF, induzida pela jararagina, somada aos efeitos sobre a interação plaqueta-colágeno, prejudica a coagulação que unida à coagulopatia de consumo, pode implicar em risco de morte da vítima (Kamiguti et al., 1996a).

\section{Interação com outros tipos de células}

A observação de que a jararagina interage com integrinas $\alpha_{2} \beta_{1}$ e com o colágeno, sugere a possibilidade de interações com outros sistemas celulares que não plaquetas, interferindo em efeitos mediados pela $\alpha_{2} \beta_{1}$. Esses efeitos incluem mudanças no crescimento de fibroblastos em redes de colágenos compreendidos por colágenos fibrilares do tipo 1 (Zigrino et al., 2002). Uma vez expostos à jararagina, ligações na superfície celular acontecem através da interação com integrinas $\alpha_{2} \beta_{1}$ e, diferentemente das plaquetas, a ligação da jararagina ao $\alpha_{2} \beta_{1}$ é suficiente para induzir as sinalizações essencialmente idênticas às observadas para o colágeno fibrilar e promove a expressão de MMP-1, MT1-MMP e integrinas $\alpha_{2} \beta_{1}$ (Zigrino et al., 2002).

Em fibroblastos, a jararagina atua como um substrato que mimetiza o 
colágeno, que se liga e ativa integrinas. Por outro lado, em agregação plaquetária induzida pelo colágeno, jararagina se liga ao domínio $\alpha_{2} \beta_{1}$ da integrina, inibindo a sinalização intracelular mediada pelo colágeno. Kamiguti et al., (2000) sugere que apenas a ligação jararagina $/ \alpha_{2} \beta_{1}$ seja suficiente para que a efetiva transdução do sinal em plaquetas aconteça.

Os mecanismos de ação das SVMPs em células endoteliais ainda estão fracamente elucidados. Entretanto, Masuda et al., (1998) especula que as P-III SVMPs possam promover a apoptose das células endoteliais e não um efeito citotóxico.

\section{Atividade pró-inflamatória induzida pela jararagina}

A jararagina atua em uma variedade de diferentes mecanismos envolvidos na homeostase e é diretamente relacionada na hemorragia local e sistêmica observadas em pacientes envenenados (Kamiguti et al., 1991; Paine et al., 1992) e in vitro (Kamiguti et al., 1991; Gallagher et al., 2005). Outro importante papel desenvolvido pela jararagina é o de promover uma forte atividade próinflamatória, acarretando em extensos danos ao tecido local (Costa et al., 2002; Laing et al., 2003) e prejudicando a proliferação de células dos sistemas responsáveis pela reconstituição do tecido (Ho et al., 2002).

Apesar dos recentes estudos realizados para se compreender melhor os efeitos locais desencadeados, após acidentes botrópicos, em relação às toxinas envolvidas no processo de ativação dos componentes pró-inflamatórios endógenos e o mecanismo desencadeado imediatamente após o contato destas com os tecidos, ainda não estão bem esclarecidos.

A exposição das células MPACs (Murin Peritoneal Adherent Cells) à jararagina estimula, após um período de aproximadamente 4 horas, a produção de 
mediadores imunes de amplo espectro como: o TNF- $\alpha$, a IL-1 $\beta$ (InterLeukin-1 $\beta$ ) e a IL-6 mRNAs (InterLeukin-6). Entretanto, quando recombinantes solúveis de TNF- $\alpha$ e IL-6 foram encubados na presença de jararagina, clivagens proteolíticas foram observadas.

A toxina nativa também estimula a subseqüente degradação das citocinas produzidas por clivagem proteolítica. O TNF- $\alpha$ e a IL-6 foram rapidamente degradados, enquanto que a atividade sobre a IL-1 $\beta$ foi mínima (Clissa et al., 2001).

A susceptibilidade do TNF- $\alpha$ e da IL-6 ao efeito catalítico da Jararagina, não é clara, mas, provavelmente, tenha correlação com a presença de pontes dissulfeto, presentes no TNF- $\alpha$ e na IL-6 (Callard e Gearing, 1994) e ausentes na IL1 $\beta$. Possivelmente, as pontes dissulfeto geram características estruturais, que expõem resíduos hidrofóbicos na superfície das moléculas e que são necessários para a atividade proteolítica da jararagina. Deste modo, a jararagina, na sua forma nativa, pode atuar como ativador do mecanismo endógeno da resposta inflamatória (Mourada-Silva et al.,1996a), induzindo à produção de citocinas pela estimulação de células inflamatórias (Clissa et al., 2001). Células endoteliais também são ativadas e liberam óxido nítrico (NO) e IL-6 em resposta à ação da jararagina (Schattner et al., 2005).

As citocinas, por possuírem um papel de grande relevância na regulação de mecanismos inflamatórios, têm se mostrado como fortes candidatas a serem os possíveis agentes endógenos pró-inflamatórios, liberados em resposta ao envenenamento. A produção de citocinas tem sido descrita em modelos experimentais e em vítimas de acidentes botrópicos e crotálicos (Lomonte et al. 1993; Barravieira et al. 1995; Barros et al. 1998; Petricevich et al. 2000). Porém, poucas evidências sobre o envolvimento direto das citocinas, na inflamação ocasionada por envenenamentos ofídicos, estão disponíveis na literatura. 


\section{Jararagina e o câncer}

Recentes estudos foram realizados com o intuito de investigar a habilidade da jararagina em interferir em mecanismos relacionados ao câncer. $\mathrm{O}$ tratamento de cultura de células de melanoma humano com jararagina levou a alterações morfológicas celulares, variabilidade e adesão à proteínas da matriz extracelular, resultando em uma significante redução da metástase pulmonar quando comparadas aos controles (Correa et al., 2002). Em uma diferente metodologia, polipeptídeos similares aos da angiostatina foram gerados a partir da hidrólise do plasminogênio pela jararagina in vitro. Os fragmentos resultantes isolados inibiram a proliferação de células endoteliais de maneira similar à angiostatina (Ho et al., 2002). Esses dados, aliados a resultados previamente encontrados na literatura, mostram que a jararagina é capaz de liberar componentes endógenos bioativos e fatores antiangiogênicos, o que contribuiria para uma resposta regenerativa de danos locais em tecidos após a mordida da cobra. Entretanto, a principal implicação desses estudos é o de que a jararagina parece possuir propriedades anti-tumorais (Correa et al., 2002; Ho et al., 2002).

\section{Anticorpos e inibidores da jararagina}

Dada a importância da jararagina, assim como a de outras SVMPs, em patologia de venenos, diversas estratégias têm sido elaboradas para inibir ou neutralizar essa família de proteínas, com a finalidade de desenvolver um tratamento mais efetivo para o combate dos efeitos locais provenientes da mordida, assim como a procura por inibidores endógenos às SVMPs presentes no soro de certos mamíferos e répteis, naturalmente resistentes ao veneno de serpentes (Domont et al., 1991; Fox e Bjarnason et al., 1998). Esses inibidores, por exemplo, poderiam ser retirados do próprio soro de B. jararaca ou de gambás (Rocha et al., 2002; Jurgilas et al., 2003). 
O inibidor de SVMPs, BJ46a, similar aos membros da superfamília de proteínas cistatinas, isolado a partir do soro da $B$. jararaca, dá origem a um complexo formado por ligações não covalentes com a jararagina, acarretando na inibição de suas atividades hemorrágicas e catalíticas (Valente et al., 2002). Similarmente, o DM 43 (Neves-Ferreira et al., 2002) e o PO41 (Jurgilas et al., 2003), inibidores de SVMPs, são incluídos na superfamília das imunoglobulinas, isoladas a partir dos soros de Didelphis marsupialis e Philander opossum, respectivamente. Ambos formam complexos estáveis com a jararagina e inibem sua atividade hemorrágica, fibrinolítica e proteolítica.

Outros exemplos de inibidores da jararagina são antivenenos que vêm se mostrando bastante eficazes na inibição da atividade hemorrágica, induzida por jararagina. Um exemplo, soros extraídos de coelhos, imunizados com veneno de $B$. jararaca, foram capazes de neutralizar as toxinas responsáveis pela atividade hemorrágica de venenos de outras espécies de serpentes Bothrops (Lopes-Ferreira et al., 1992). Entretanto, sabe-se que o desenvolvimento de antivenenos com anticorpos mais específicos que pudessem atuar diretamente nas toxinas mais importantes, o que contribuiria, de maneira muito significativa, na eficácia da soroterapia (Theakston e Reid, 1993; Harrison et al., 2002). Um total de sete anticorpos monoclonais, cultivados contra a jararagina, reagiram preferencialmente com a jararagina-C. $\mathrm{O}$ anticorpo monoclonal (MAJar3) inibiu as interações jararagina/colágeno, atividades proteolíticas para peptídeos e substratos, e, ainda, a atividade hemorrágica induzida pela jararagina (Tanjoni et al., 2003a).

Ao estabelecer a ligação de anticorpos anti-jararagina-C aos domínios desintegrina e rico em cisteína, espera-se que as interações da molécula com as integrinas $\alpha_{2} \beta_{1}$ fiquem comprometidas (Clissa et al., 2006). Esse fato contribuiria 
para a observada inibição da hemorragia dermal (Harrison et al., 2000). Entretanto, a evidência de que a ligação da MAJar3 ao domínio desintegrina neutraliza ambas as atividades hemorrágicas e de ligação ao colágeno; sugere que sítios no domínio desintegrina sejam importantes na interação com substratos presentes na matriz extracelular, permitindo, assim, que as atividades enzimáticas aconteçam (Laing e Moura-da-Silva, 2005).

Como pode ser observado, jararagina tem sido amplamente estudada e explorada em seus mais diversos aspectos medicinais, nos casos de acidentes ofídicos, assim como ferramenta para o entendimento do mecanismo molecular de ação para essa classe de toxinas. Apesar de toda a informação acumulada para as atividades biológicas de SVMPs da classe P-III , pouco se sabe sobre os mecanismos moleculares de adesão e propriedades dos domínios D e C.

\section{7 - Contextualização do projeto desenvolvido}

Embora seja de conhecimento as importantes atividades biológicas das SVMPs P-III, o envolvimento de cada domínio nessas atividades ainda não é totalmente conhecido e o estudo estrutural dessas moléculas pode trazer importantes informações sobre a relação estrutura-função dessas proteínas. Nesse sentido, foram iniciados estudos estruturais de uma proteína da classe P-III, isolada de veneno de $B$. jararaca, em colaboração com a Dra. Ana Maria Moura-da-Silva, do Instituto Butantan, que nos forneceu amostra purificada de acordo com Paine (1992). Segundo a literatura, a proteína purificada de acordo com Paine é a jararagina. Testes de cristalização foram realizados com a proteína e os cristais obtidos foram coletados (Souza et al., 2000). Através de substituição molecular foi possível determinar a estrutura do domínio catalítico, porém o refinamento da estrutura ficou prejudicado em função de não ser possível determinar a estrutura dos domínios desintegrina e 
rico em cisteína. Foi dada continuidade ao estudo, e, para solucionar o problema da degradação proteolítica da amostra, a purificação da proteína começou a ser realizada no laboratório, com um protocolo diferente daquele utilizado anteriormente descrito por Paine. A proteína isolada apresenta a mesma massa molecular aparente da jararagina e também apresenta atividade hemorrágica. Cristais desta proteína foram obtidos e a estrutura da molécula inteira foi determinada, observando-se, pela estrutura, que se trata da bothropasina, uma proteína homóloga (isoforma) à jararagina. Com a estrutura da bothropasina elucidada foi possível determinar a estrutura da proteína anteriormente cristalizada. Constatou-se que as duas estruturas determinadas, com proteínas purificadas de maneiras diferentes, são de bothropasina, fato que sugere que os diferentes protocolos de purificação não são suficientes para a obtenção específica de jararagina ou bothropasina.

Um fato interessante é que todos os estudos de atividade da jararagina, descritos nos tópicos anteriores, foram realizados com proteína isolada segundo Paine (1992). 


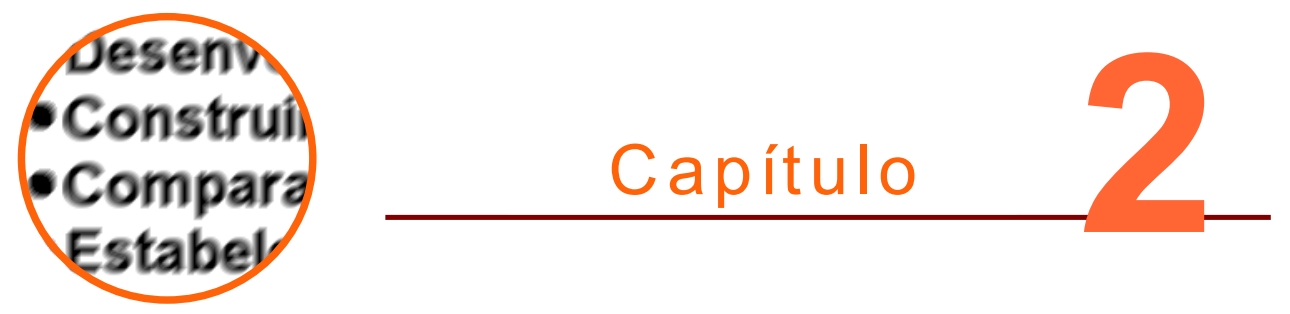

\section{OBJETIVOS}

O principal objetivo do presente trabalho foi o estudo estrutural de uma metaloproteinase/desintegrina, proteína da classe P-III das SVMPs, isolada do veneno de B. jararaca.

Objetivos específicos:

- Desenvolver protocolos de cristalização da proteína isolada de veneno bruto, da serpente Bothrops jararaca.

- Construir e analisar a estrutura tridimensional da proteína.

- Comparar e correlacionar a estrutura da proteína com proteínas homólogas.

- Estabelecer um mecanismo de ação para essa classe de proteínas multimodulares. 


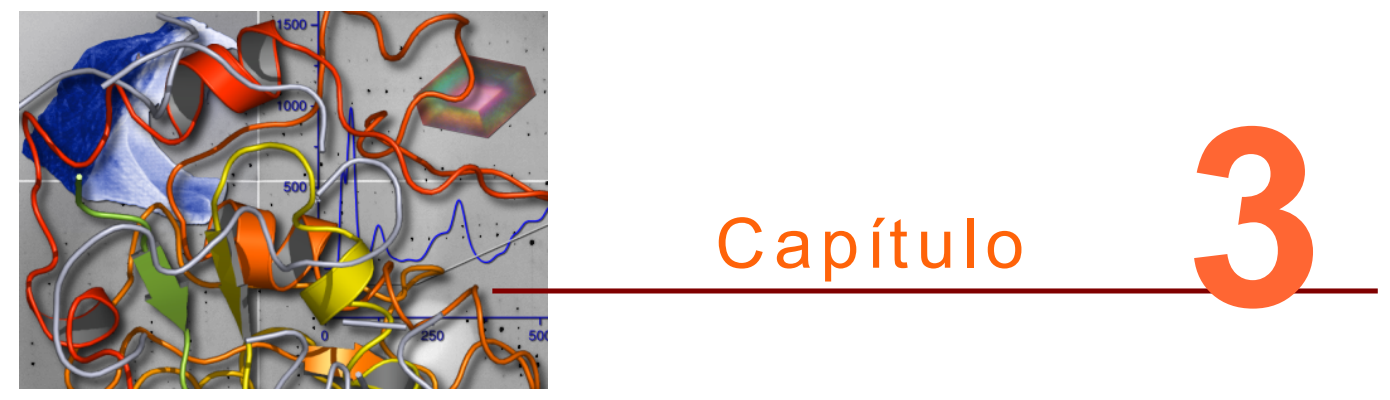

\section{DETERMINAÇÃO E REFINAMENTO DA ESTRUTURA DA BOTHROPASINA}

\section{Obtenção da proteína bothropasina}

O veneno bruto de Bothrops jararaca, na forma liofilizada, gentilmente cedido pelo Laboratório de Herpetologia do Instituto Butantan, na cidade de São Paulo, foi obtido, a partir de diversas amostras extraídas de diferentes exemplares de serpentes. A amostra liofilizada foi mantida a $4 \infty \mathrm{C}$ até o uso.

A bothropasina foi isolada a partir de $50 \mathrm{mg}$ do veneno liofilizado de $B$. jararaca ressuspendido em $1 \mathrm{~mL}$ da solução tampão $20 \mathrm{mM}$ Tris- $\mathrm{HCl}, \mathrm{pH}$ 8,0, centrifugados a $12000 \mathrm{x}$ g durante 15 minutos e submetidos a cromatografia de troca iônica. Para tanto, a coluna DEAE-Sepharose Fast Flow (Pharmacia, volume de 70 $\mathrm{mL}$ ) foi previamente equilibrada com a mesma solução tamponante, acoplada a um sistema $f$ KTA Explorer $10(\mathrm{GE})$.

Após a remoção das proteínas não aderidas à resina da coluna com, aproximadamente, $210 \mathrm{~mL}$ do tampão de equilíbrio, foi efetuado o processo de eluição. A fase eluente utilizada foi um gradiente composto por três estágios: (1) gradiente linear de 10 vezes o volume da coluna (total de $700 \mathrm{~mL}$ ) a $40 \%$ de $\mathrm{NaCl}$ 0,5 M em mesmo tampão; (2) rápido gradiente linear de 40 a $100 \%$ de $\mathrm{NaCl} 0,5$ 
M em 20 mM Tris-HCl, pH 8,0 e (3) 120 mL de solução a 100\% de $\mathrm{NaCl}$ 0,5 M em 20 mM Tris- $\mathrm{HCl}, \mathrm{pH}$ 8,0 (figura 3.1 (a)).

A cromatografia foi realizada em um fluxo constante de $3 \mathrm{~mL} \cdot \mathrm{min}^{-1} \mathrm{e}$ frações contendo proteína com massa molecular aproximada de $55 \mathrm{kDa}$ (estimada por SDS-PAGE, figura 3.1 (c)), foram reunidas e a amostra foi dialisadas durante 18 horas a $4 \infty \mathrm{C}$ contra tampão Tris- $\mathrm{HCl} 20 \mathrm{mM}$, pH 8,0 com $250 \mathrm{mM} \mathrm{NaCl}$, concentradas a $1 \mathrm{~mL}$ e aplicada em uma coluna de exclusão por massa molecular Superdex75 (Pharmacia, 1,6 cm x $60 \mathrm{~cm}$ ), equilibrada com o mesmo tampão da diálise. A eluição das proteínas foi realizada a um fluxo constante de $0,5 \mathrm{~mL} \cdot \mathrm{min}^{-1} \mathrm{e}$ foram coletadas frações de $1 \mathrm{~mL}$. As cromatografias foram monitoradas pela leitura da absorbância a $280 \mathrm{~nm}$ e todas as etapas foram efetuadas a baixa temperatura $(4 \infty \mathrm{C})$. As figuras 3.1 (a), (b) e (c), ilustram, de maneira resumida, as etapas envolvidas no processo de obtenção da bothropasina

As frações obtidas de bothropasina foram analisadas quanto ao seu grau de pureza, por eletroforese em gel de poliacrilamida, na presença de SDS, conforme descrito por Laemmli (Laemmli, 1970) (figura 3.1 (c)). A atividade biológica foi estudada através de ensaios de atividade hemorrágica que foram realizados em colaboração com a Profa. Dra. Heloisa Selistre-de-Araújo, do Departamento de Ciências Fisiológicas da Universidade Federal de São Carlos. A atividade hemorrágica foi determinada pela Dose Mínima Hemorrágica (DMH), que é definida como a quantidade mínima de enzima necessária para produzir um halo hemorrágico de $1 \mathrm{~cm}$ de diâmetro na pele de animais como coelho ou camundongos, duas horas após a injeção (Kondo et al., 1960). Solução de bothropasina (100 $\mu \mathrm{L})$ foi injetada intradermicamente em camundongos de cerca de 25 g. Duas horas após a injeção, os camundongos foram sacrificados e as peles removidas para determinação do halo 
hemorrágico. A DMH para a bothropasina foi de $20 \mu \mathrm{g}$ o que está de acordo com o relatado na literatura (Mandelbaum, 1982).
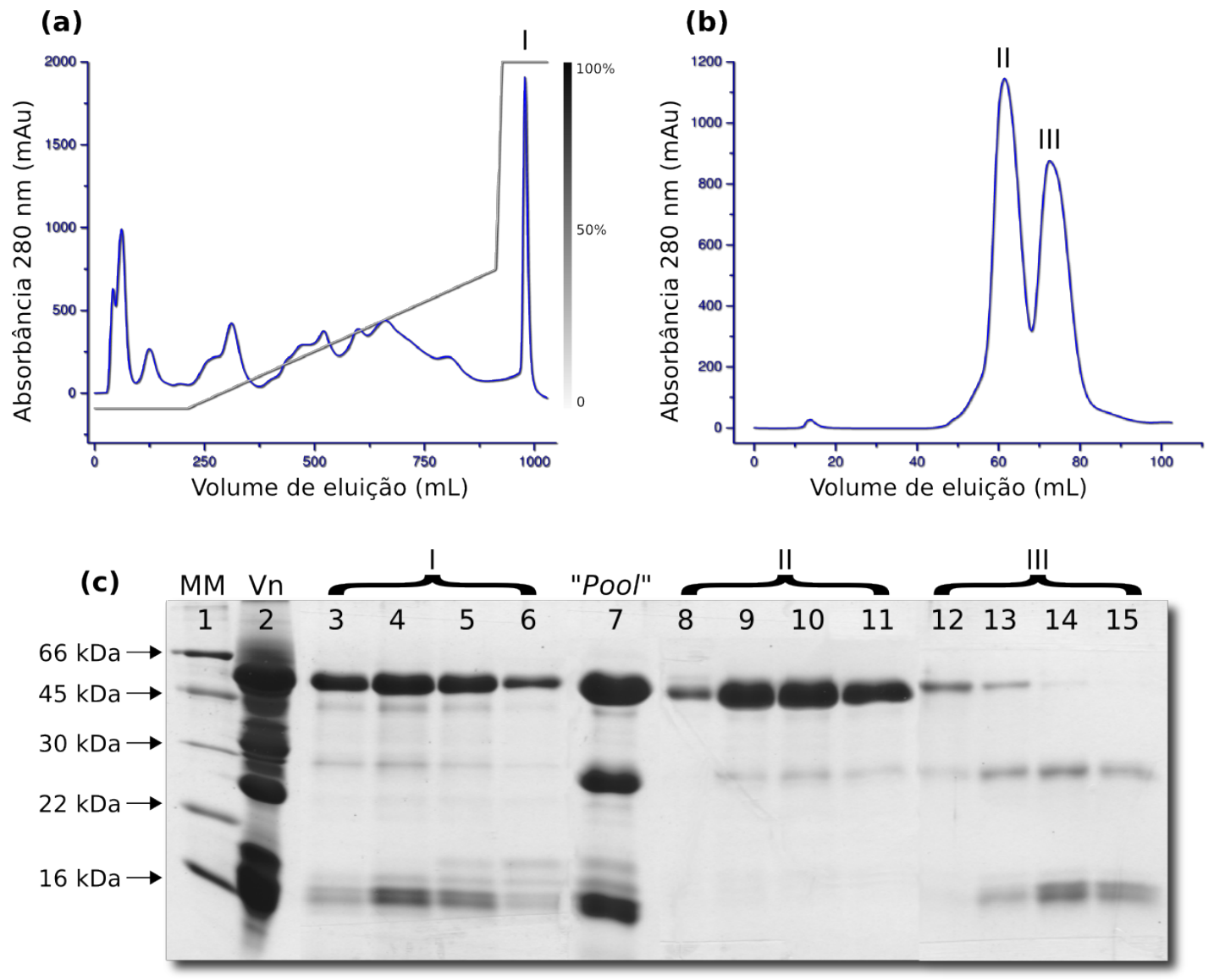

Figura 3.1: Purificação da bothropasina. (a) $50 \mathrm{mg}$ de veneno bruto ressuspenso em $1 \mathrm{~mL}$ de solução tampão $20 \mathrm{mM}$ Tris-HCl, pH 8,0 e aplicado a cromatografia de troca iônica em coluna DEAE-Sepharose $F F$. A curva cinza representa o gradiente salino. (b) Cromatografia das frações eluídas em (a) "I" em coluna de exclusão por massa molecular Superdex75. A bothropasina elui com um grau de pureza de aproximadamente 95\% (frações "II"), suficientes para os testes de cristalização. (c) Gel de poliacrilamida $15 \%$ indicando as etapas mais relevantes do processo de purificação da bothropasina. Poço 1: marcador de massa molecular; Poço 2: veneno bruto; Poços 3-6: frações eluídas com $100 \% \mathrm{NaCl}$ 0,5 M 20 mM Tris-HCl, pH 8,0; Poço 7: combinação das amostras 3-6 aplicado na coluna Superdex75; Poços 8-11: frações eluídas da coluna (pico II) com bothropasina utilizada nos testes de cristalização; Poços 12-15: frações com contaminantes eluídos no pico III da coluna Superdex75.

A concentração protéica das amostras provenientes da cromatografia foi estimada através do método descrito inicialmente por Bradford (Bradford, 1976). A 
amostra passou por mais um processo de diálise (aproximadamente 18 horas) contra a solução tamponante fosfato de sódio $50 \mathrm{mM}$ em pH 6,0.

\section{Obtenção da bothropasina sob forma cristalina}

Visando ao aumento da estabilidade protéica através da inibição da atividade enzimática e, dessa forma, contribuindo para a qualidade na formação da rede cristalina, o inibidor não específico POL647 (Gomis-Ruth et al., 1998) foi encubado em uma razão molar proteína/inibidor igual a 1:50 (POL647 $8 \mathrm{mM}$ ) por cerca 120 min à temperatura de $4 \infty \mathrm{C}$. Posteriormente, a proteína foi concentrada para aproximadamente $8 \mathrm{mg} \cdot \mathrm{mL}^{-1}(160 \mu \mathrm{M})$ e utilizada em experimentos de cristalização, com o emprego do método de difusão de vapor com gotas suspensas (Hampel et al., 1968).

Em uma tentativa inicial para obtenção de cristais, foi realizada uma triagem, através de conjuntos de soluções comerciais de cristalização do tipo matrizes esparsas "Crystal Screen" I e II (Hampton Research) a $400 \mathrm{C}$ e $1800 \mathrm{C}$. Os ensaios consistiam de gotas suspensas de volume igual a $8 \mu \mathrm{L}$ (50\% proteína e $50 \%$ solução mãe) e reservatório contendo $1 \mathrm{~mL}$ de solução mãe.

Após um período de 5 dias, foram observados cristais protéicos em diversas condições nas matrizes esparsas. Varreduras foram feitas nas condições que se mostraram mais promissoras. A condição ideal de cristalização foi estabelecida como sendo: acetato de amônia $40 \mathrm{mM}$, solução tamponante de acetato de sódio 100 $\mathrm{mM}, \mathrm{pH} 4,6$ e $29 \%$ PEG 4000 como agente precipitante a temperatura de $4 \infty \mathrm{C}$ (figura 3.2). 

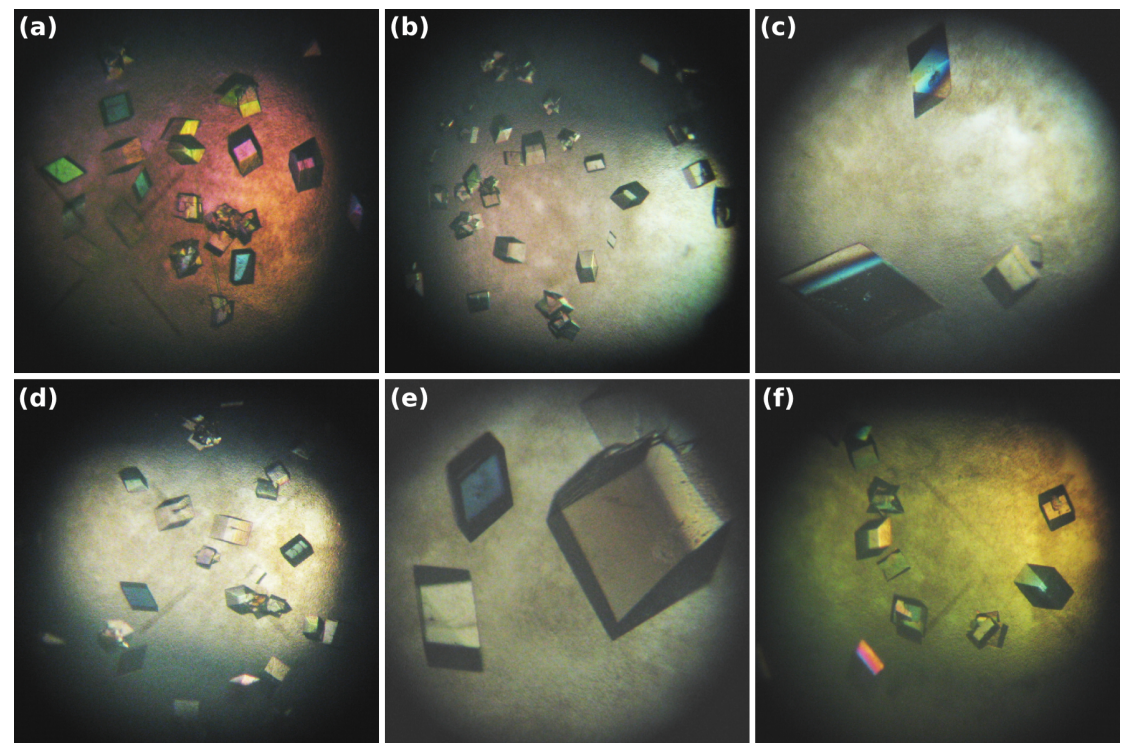

Figura 3.2: Cristais da proteína bothropasina. As imagens de (a)-(f) mostram as melhores condições para a obtenção de cristais de bothropasina. Os cristais apresentam uma morfologia semelhante, porém algumas formas como trapézio e cúbica também são observadas. Algumas condições com volume menor de agente precipitante, figuras (c) e (e), os cristais apresentaram um crescimento acima do esperado, mas com baixo poder de difração. O tamanho médio dos cristais de bothropasina é de $0,8 \times 0,5 \times 0,6 \mathrm{~mm}$.

\section{Coleta de dados de difração}

Vários cristais foram testados, sempre em temperatura criogênica (100 K, crioprotegidos com adição de glicerol $5 \%$ (v/v) à solução mãe), e 8 conjuntos de dados foram coletados em uma fonte de raios $\mathrm{X}$ anôdo rotatório, disponível no laboratório, modelo ultraX 18 (RIGAKU/MSC) com detector do tipo placa de imagem, modelo Mar345dtb (MAR Research). Um conjunto de dados a mais alta resolução foi coletado na linha MX1 (Polikarpov et al., 1998), no Laboratório Nacional de Luz Síncrotron (LNLS/Campinas), equipado com placa MARccd (MAR Research) utilizando um comprimento de onda igual a 1,427 Å. Um exemplo da imagem de difração medida no LNLS é mostrada na figura 3.3. 


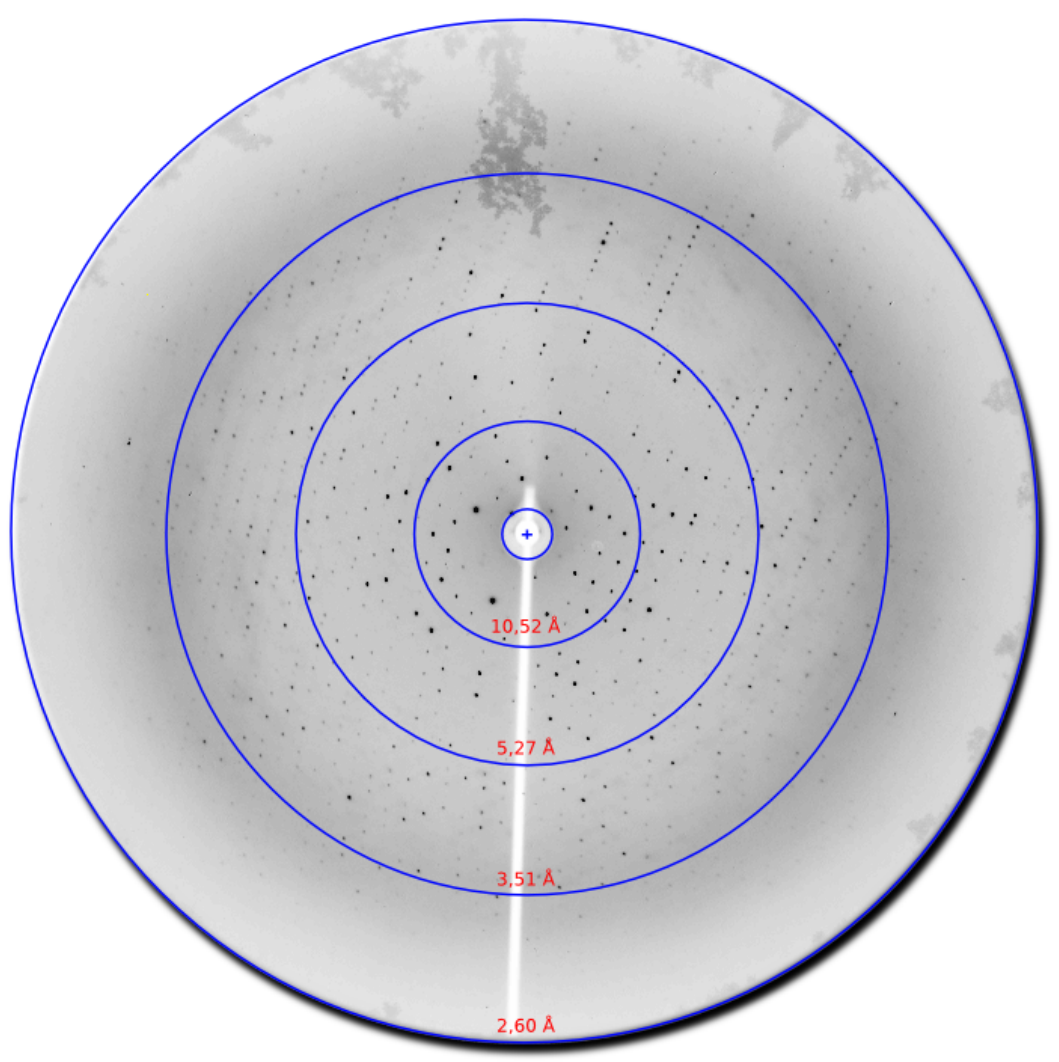

Figura 3.3: Padrão de difração do cristal de bothropasina. Imagem característica obtida de um cristal congelado após imersão por, aproximadamente, 2 min em solução de $\mathrm{NaI}$ 0,5 M. Imagem com 01 grau de oscilação com tempo de $90 \mathrm{~s}$ de exposição.

Todos os conjuntos de imagens de difração foram processados no programa MOSFLM (Leslie, 1992) e as intensidades foram escalonadas e reduzidas no programa SCALA (Evans, 1993), que inclui o programa TRUNCATE (French e Wilson, 1978), ambos do pacote de programas CCP4 (Collaborative Computational Project Number 4 (1994)). Os parâmetros e estatísticas do conjunto de dados processados são mostrados na tabela 3.1. 
Tabela 3.1: Parâmetros e estatísticas da coleta e processamento dos dados de difração de raios $\mathrm{X}$ para a proteína na presença de $\mathrm{NaI}$ (cristais crescidos a $4^{\circ} \mathrm{C}$ ).

\begin{tabular}{ll}
\hline \multicolumn{2}{l}{ Valores em parênteses são referentes à camada mais externa de resolução } \\
\hline Grupo espacial & $\begin{array}{l}\mathrm{P} 2{ }_{1}{ }_{1} 2_{1} \\
\mathrm{a}=72,5 \AA, \mathrm{b}=101,2 \AA, \\
\mathrm{c}=133,6 \AA\end{array}$ \\
Parâmetros da rede & $20,0-2,85(3,00-2,85)$ \\
\hline Limites de resolução $(\AA)$ & 200 \\
Número de imagens & 1 \\
$\Delta \varphi\left(^{\circ}\right)$ & 0,7 \\
Mosaicidade $\left({ }^{\circ}\right)$ & $23552(3384)$ \\
Reflexões únicas & $5,7(5,8)$ \\
Multiplicidade & $7,3(32,4)$ \\
$\mathrm{R}_{\text {sym }}(\%)$ & $17,9(4,5)$ \\
$\langle(\mathrm{I}) / \sigma(\mathrm{I})\rangle$ & $99,7(100,0)$ \\
Completeza $(\%)$ &
\end{tabular}

O número de moléculas presentes na unidade assimétrica foi estimado por meio do programa Matthews_coef (parte do pacote CCP4), que faz uso da metodologia proposta por Matthews (Matthews, 1968).

Considerando-se a massa molecular da bothropasina, como sendo aproximadamente $52 \mathrm{kDa}$, foram estimadas duas moléculas como constituintes da unidade assimétrica cristalina, resultando em um volume de Matthews equivalente a $2,6 \AA^{3} / \mathrm{Da}$ e conteúdo de solvente no cristal de $49,8 \%$. O fator de temperatura (B) do cristal encontrado por regressão linear no gráfico de Wilson foi de $80,7 \AA^{2}$.

\section{Faseamento e construção do modelo cristalográfico}

A dificuldade na obtenção de cristais de metaloproteinases/desintegrinas (MDC) da classe P-III, provavelmente devido à sua complexidade e flexibilidade em seus multidomínios, tem como conseqüência a pouca informação estrutural de proteínas dessa classe. Somente em 2006 foi determinada a primeira estrutura de uma MDC isolada do veneno de Crotalus atrox (Takeda et al., 2006). O elevado número 
de pontes dissulfeto, que torna a produção de formas recombinantes da proteína um processo bastante laborioso, a presença de poucas formas homogêneas no veneno (Moura-da-Silva et al., 2003) e a necessidade do uso de um inibidor específico, capaz de reduzir a auto-degradação protéica, também colaboram para a dificuldade de se obter cristais.

Através do método de “quick cryo-soaking" (Dauter et al., 2000; Nagem et al., 2001; 2003), cristais protéicos foram imersos em solução de 0,5 M de $\mathrm{NaI}$ (dissolvidos em acetato de sódio 100 mM, pH 4.6 e 29\% PEG 4000), por um período de aproximadamente $3 \mathrm{~min}$, visando à obtenção de melhores fases experimentais.

As fases foram determinadas com a utilização de um protocolo misto de faseamento, implementado no programa PHASER ${ }^{1}$ (McCoy et al., 2004; 2005), que faz uso das técnicas de Substituição Molecular (SM), combinado com faseamento por dispersão anômala. No presente trabalho, a dispersão anômala foi a um único comprimento de onda (SAD).

Os modelos de busca para a SM foram encontrados através de alinhamento seqüencial entre a bothropasina e as proteínas depositadas no PDB "Protein Data Bank". Os melhores alinhamentos foram obtidos para a acutolisina (PDB 1BSW) uma metaloprotease de classe P-I e trimestatina (PDB 1J2L) uma desintegrina RGD.

A posição dos sítios de iodo foi determinada com auxílio do programa PHASER. Um total de 8 sítios de iodo, com ocupação acima de $80 \%$, foi encontrado no conjunto de dados. As fases iniciais foram então calculadas utilizando-se as coordenadas dos átomos de iodo, assim como as moléculas homólogas em um

1 A versão utilizada do programa PHASER no presente trabalho foi gentilmente cedida e também teve a participação efetiva, durante todo o processo de faseamento, pelo Prof. Randy Read do "Medical Research Council" - Universidade de Cambridge, UK, durante o desenvolvimento do meu Programa de Doutorado no País com Estágio no Exterior (PDEE) na mesma universidade. Maiores informações podem ser encontradas no apêndice I. 
processo misto de faseamento. Os mapas iniciais calculados não permitiram o traçado automático nem mesmo manual para os átomos das cadeias principais e laterais do domínio rico em cisteína. Através de ciclos de modificação de densidade eletrônica e achatamento de solvente utilizando o programa RESOLVE (Terwilliger, 2003), fragmentos do domínio C puderam ser traçados para as duas moléculas presentes na unidade assimétrica.

Após aplicação da solução por SM, foram feitos refinamento de corpo rígido, anelamento simulado, com o pacote de programas CNS (Brunger et al., 1998) e PHENIX (Adams et al., 2004). Foram feitos ciclos de refinamento no espaço real (modificações manuais do modelo, através da inspeção dos mapas de densidade eletrônica usando o programa gráfico Coot (Emsley e Cowtan, 2004)), alternados com cálculos intermediários no espaço recíproco para refinamento de posições atômicas, restrições geométricas e de contato, refinamento de fator de temperatura isotrópico individual para todos os átomos. Além de minimização de funções de energia e TLS. Foram utilizados os programas Refmac 5.0 (Collaborative Computational Project, Number 4) e PHENIX_refine (Afonine et al., 2005).

Ciclos exaustivos de construção e reconstrução do modelo estrutural, aliados à estrutura primária da bothropasina (Mandelbaum et al., 1982) e a descrição das pontes dissulfeto na literatura para a catrocolastatina (uma SVMP de C. atrox (Calvete et al., 2000)), tornaram possível a construção de $100 \%$ da estrutura da bothropasina. O monitoramento da coerência do modelo com os dados experimentais foi conduzido através da análise da variação do fator $\mathrm{R}$, juntamente com o fator $\mathrm{R}_{\text {free }}$ (Validação Cruzada, Brunger et al., 1998). 


\section{Validação da estrutura da bothropasina}

Foram utilizadas 23552 reflexões no cálculo do $\mathrm{R}_{\text {factor }}$ para o “conjunto de trabalho" e 1201 reflexões para o "conjunto teste", ou seja, 5,1\% do conjunto total, para o cálculo do $R_{\text {free, }}$ compreendendo uma faixa de resolução de 20,0 a 2,85 Å. Os valores finais desses índices de discrepância ficaram em 24,9\% $\left(\mathrm{R}_{\text {factor }}\right)$ e $29,3 \%$ $\left(\mathrm{R}_{\text {free }}\right)$. A introdução de moléculas de água foi feita manualmente, com o auxílio do programa Coot, sob critérios de distância mínima e máxima de 2,3 $\AA$ a 3,5 $\AA$, fator de temperatura menor que $50 \AA^{2}$ e em mapa de densidade eletrônica com nível de contorno de $1 \sigma$. O refinamento foi dado como encerrado quando não foi mais possível a melhora dos índices $\mathrm{R}_{\text {factor }} \mathrm{e} \mathrm{R}_{\text {free. }} \mathrm{O}$ modelo final é constituído por 2 moléculas na unidade assimétrica (com um total de 838 resíduos de aminoácidos), 2 moléculas de POL647 e 103 moléculas de água.

Os valores finais para os desvios médios quadráticos para comprimentos e ângulos de ligações interatômicas da estrutura foram $0,015 \AA$ e $1,815^{\circ}$ respectivamente. $\mathrm{O}$ fator de temperatura médio para todos os átomos das cadeias protéicas foi de $57,2 \AA^{2}$.

De forma a ilustrar a qualidade dos valores finais de $\mathrm{R}$ e $\mathrm{R}_{\text {free }} \mathrm{da}$ bothropasina, a figura 3.4 mostra a média dos valores observados para estruturas refinadas à mesma resolução, ou seja, 2,85 Å. Dadas as características da proteína, como ausência de estruturas secundárias bem definidas para uma boa parte da estrutura, resolução e ainda por ter um de seus domínios construídos manualmente, as estatísticas de $\mathrm{R}$ e $\mathrm{R}_{\text {free }}$ podem ser consideradas como bastante satisfatórias e, como mostrado na figura 3.4, dentro de valores aceitáveis. 


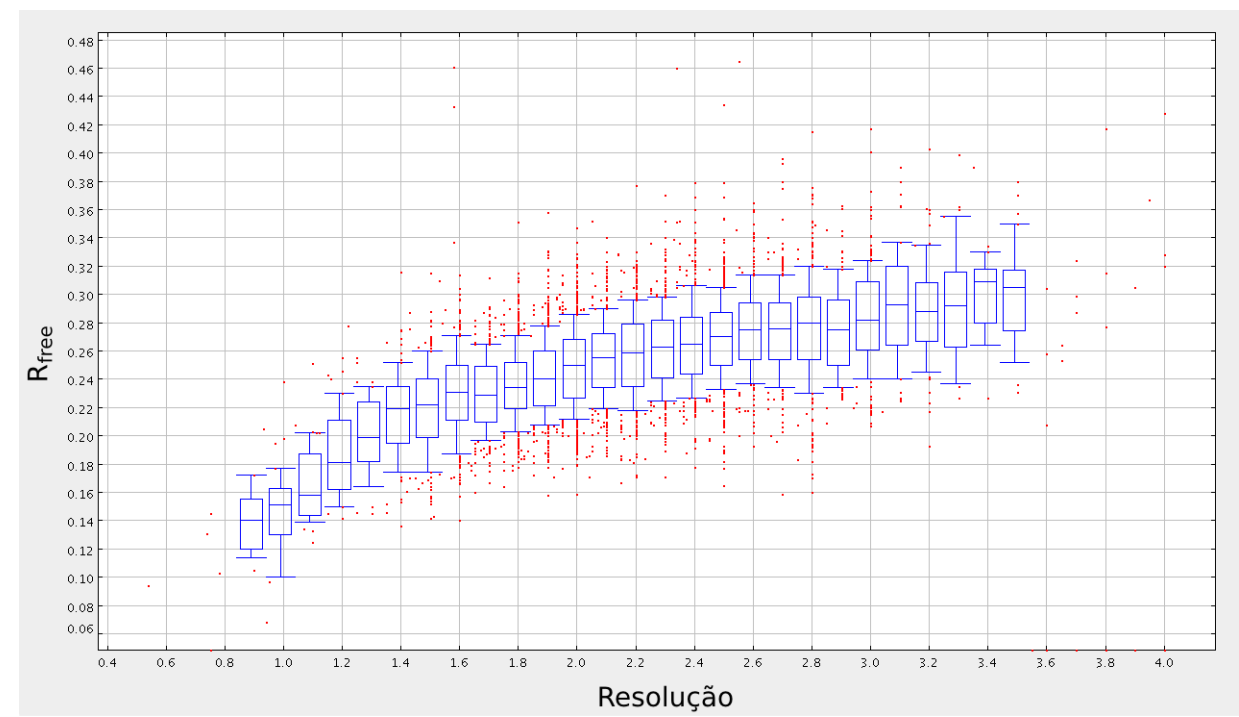

Figura 3.4: Valores de $\boldsymbol{R}_{\text {free }}$ para estruturas depositadas no PDB em função da resolução. $O$ valor de $R_{\text {free }}$ esperado para uma estrutura refinada a $2,85 \AA$, de acordo com estatísticas do PDB, deveria estar entre aproximadamente 26 e $30 \%$. A bothropasina teve valor final de $\mathrm{R}_{\text {free }}$ igual a $29,3 \%$, portanto, dentro das estatísticas do PDB. Figura adaptada de "Harry Plotter".

A análise do diagrama de Ramachandran (figura 3.5), gerado pelo PROCHECK (Laskowski et al., 1993), mostra que 671 resíduos (80,0\%) encontramse nas regiões mais favoráveis, 158 (18,9\%) estão em regiões adicionais permitidas, 9 resíduos $(1,1 \%)$ em regiões generosamente permitidas e nenhum resíduo na região desfavorável.

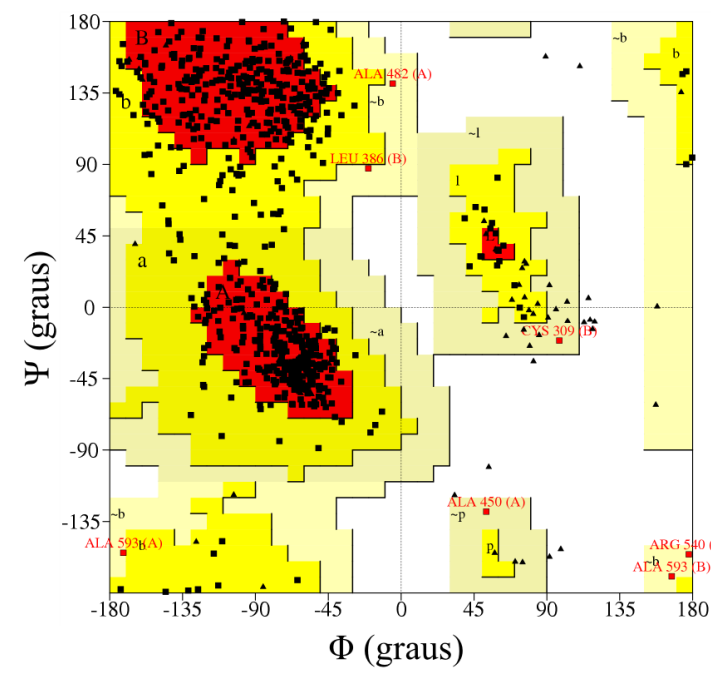

Figura 3.5:.Diagrama de Ramachandran do modelo cristalográfico final. $E$ ' avaliada a qualidade da molécula através da distribuição (e combinação) dos ângulos torsionais diedrais $(\Phi$ e $\Psi)$. O resultado indica que $80 \%$ dos resíduos se encontram nas regiões mais favoráveis (em vermelho), $18,9 \%$ estão em regiões adicionalmente permitidas (em amarelo), 1,1\% em regiões generosamente permitidas (em bege) e nenhuma ocupação na região desfavorável (em branco).

2 http://xray.bmc.uu.se/gerard/supmat/rfree2000/plotter.html. Acesso em 14 de julho de 2007. 
Os parâmetros estereoquímicos da cadeia principal foram comparados pelo PROCHECK a estruturas cristalográficas de mesma resolução (figura 3.6). A figura 3.6 (a) mostra a porcentagem de resíduos que ocupam a região mais favorável do diagrama de Ramachandran, em função da resolução de seu conjunto de dados. Já o gráfico mostrado na figura 3.6 (b), mostra o valor médio do fator G (medida da normalidade estereoquímica da estrutura), de cada resíduo na estrutura. Nesses gráficos, a região destacada em roxo corresponde a faixa de resultados para essas estruturas e a linha central representa o mínimo quadrático para a inclinação média em função da resolução, e a correspondente largura da banda indica a variação de um desvio sobre a média.
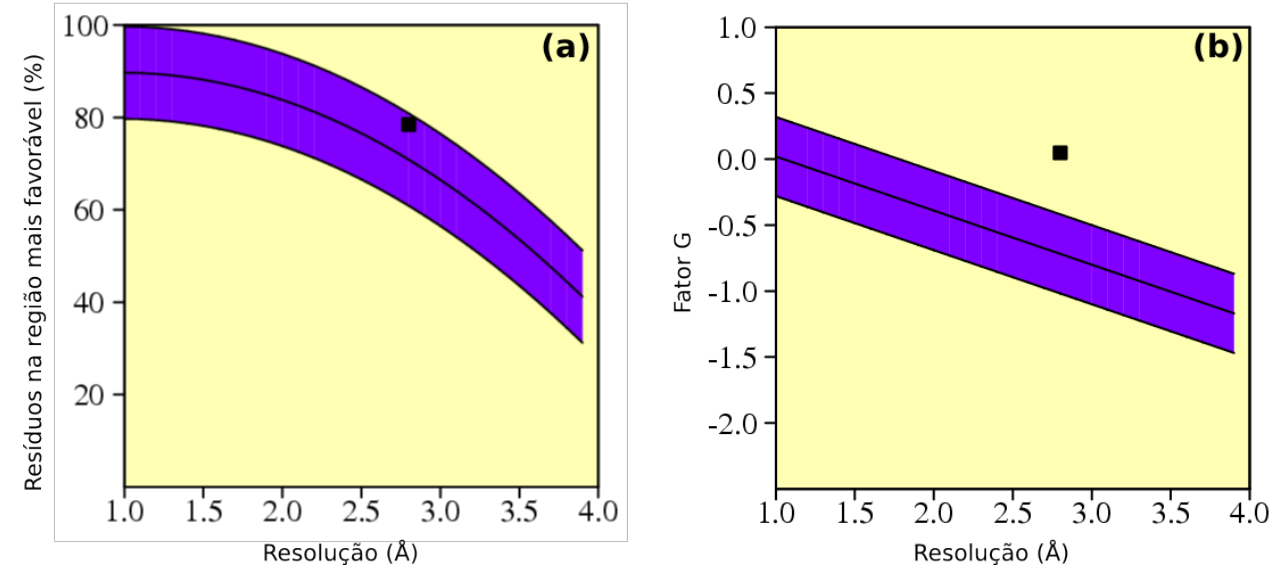

Figura 3.6: Estatísticas geradas pelo programa PROCHECK. As análises indicam que o modelo cristalográfico apresentado neste trabalho apresenta qualidade estereoquímica superior quando comparado a outras estruturas determinadas à mesma resolução. Em (a) observa-se que a quantidade obtida de, aproximadamente, $80 \%$ de resíduos na região mais favorável do diagrama de Ramachandran está acima da média e do desvio padrão na resolução de $2,8 \AA$. $O$ fator $G$ de normalidade estereoquímica, de acordo com a figura (b), apresenta-se muito superior, em relação à média das estruturas na mesma faixa de resolução.

Através das figuras 3.6 (a) e (b), pode-se observar que, de maneira geral, os resultados pós-refinamento obtidos são condizentes e dentro do esperado. Dada a dificuldade de interpretação dos mapas, o processo de traçar as cadeias principais e 
laterais dos resíduos, dentro das densidades eletrônicas, é mais laborioso. Com uma média resolução de 2,85 Å, o número de distorções nos ângulos $\Phi$ e $\Psi$, quando comparado a outras estruturas determinadas na mesma resolução, encontra-se acima da média (próximo dos $80 \%$ ). O mesmo vale para a qualidade estereoquímica do modelo. $\mathrm{O}$ fator $\mathrm{G}$ apresenta-se significativamente superior à grande maioria, ilustrando a possibilidade de se obter valores aceitáveis para $\mathrm{R}$ e $\mathrm{R}_{\text {free, }}$, mantendo-se uma boa estereoquímica.

\section{Determinação da estrutura 'nativa'}

O projeto inicial visando à determinação da estrutura cristalográfica de uma P-III de Bothrops jararaca (no caso, a jararagina) foi iniciado pela doutora Dulce Helena Ferreira de Souza, supervisora do atual projeto, no início da corrente década. A partir do fornecimento do veneno bruto pelo mesmo laboratório e seguindo o protocolo de purificação de Paine (1992), foi obtido somente um único cristal da proteína nativa.

Dados de difração de raios X foram coletados na linha CPr (hoje MX1) do LNLS, cujas estatísticas se encontram descritas na tabela 3.2.

Com auxílio da SM e utilizando a estrutura cristalográfica da acutolisina como molécula molde, o domínio $\mathrm{M}$ foi determinado. No entanto, devido à ausência de modelos cristalográficos de proteínas homólogas aos domínios $\mathrm{D}$ e $\mathrm{C}$, e da impossibilidade de se conseguir um conjunto de dados a partir de cristais derivados, a construção de $100 \%$ da estrutura foi impossibilitada. Como restava metade da molécula para ser construída, os mapas de densidade eletrônica para as cadeias laterais do domínio $M$ não eram bons o suficiente para a completa elucidação da estrutura deste domínio. 
Tabela 3.2: Parâmetros e estatísticas da coleta e processamento dos dados de difração de raios X para a proteína 'nativa' (cristais crescidos a $\left.4^{\circ} \mathrm{C}\right)$.

\begin{tabular}{ll}
\hline \multicolumn{2}{l}{ Valores em parênteses são referentes à camada mais externa de resolução } \\
\hline Grupo espacial & $\begin{array}{l}\mathrm{P} 22_{1} 2_{1} \\
\mathrm{a}=72,5 \AA, \mathrm{b}=101,2 \AA, \\
\mathrm{c}=133,6 \AA\end{array}$ \\
Parâmetros da rede & $40,1-2,70(2,85-2,70)$ \\
\hline Limites de resolução $(\AA)$ & 105 \\
\hline Número de imagens & 0,7 \\
$\Delta \varphi\left(^{\circ}\right)$ & 0,6 \\
\hline Mosaicidade $\left({ }^{\circ}\right)$ & $25611(3731)$ \\
Reflexões únicas & $2,9(2,9)$ \\
Multiplicidade & $8,5(35,0)$ \\
$\mathrm{R}_{\text {sym }}(\%)$ & $12,5(2,5)$ \\
$\langle(\mathrm{I}) / \sigma(\mathrm{I})\rangle$ & $93,4(94,0)$ \\
\hline Completeza $(\%)$ &
\end{tabular}

De posse da estrutura obtida pelo método da derivatização, descrito nesta tese, foi possível a determinação do modelo 'nativo' usando o conjunto nativo, através da técnica de substituição molecular, com auxílio do programa PHASER.

Como pode ser observado para os dois conjuntos de dados ('nativo' e derivado), parâmetros do cristal, tais como a simetria e tamanho da célula unitária, são muito parecidos. 


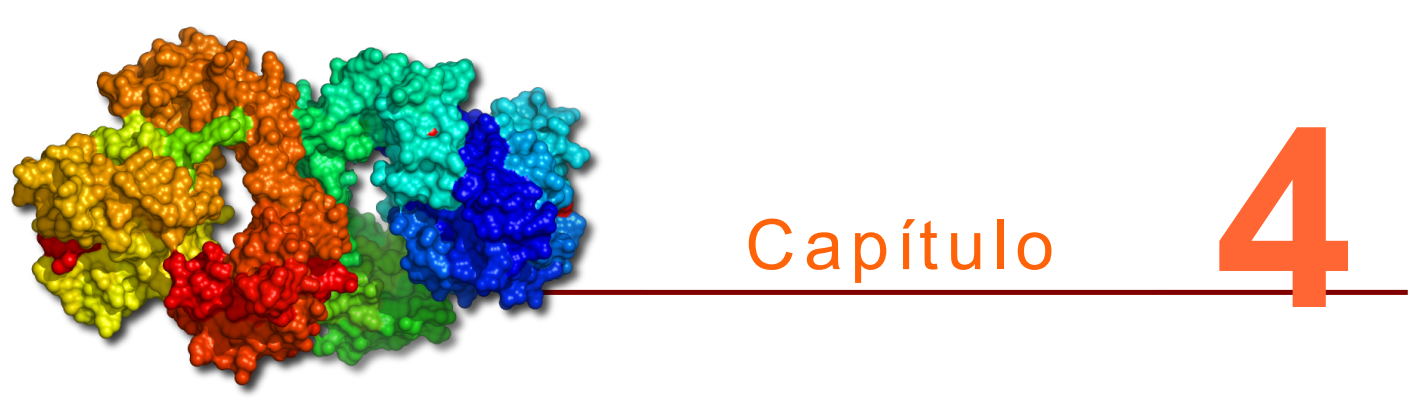

\section{ANÁLISE ESTRUTURAL DA BOTHROPASINA E DISCUSSÕES}

\section{Descrição do modelo cristalográfico}

Neste trabalho é apresentada a estrutura cristalográfica da bothropasina, presente no veneno da serpente Bothrops jararaca, em complexo com seu inibidor POL647, ilustrada na figura 4.1. O modelo final, determinado a 2,85 $\AA$ de resolução, contém 2 moléculas de bothropasina, em sua unidade assimétrica, o que totaliza 838 aminoácidos, 2 inibidores da auto-catálise POL647, 2 átomos de zinco e 6 íons cálcio ligados em seus respectivos sítios catalíticos e 103 moléculas de água (figura 4.1).

Dos 421 resíduos que compõem o monômero da bothropasina, apenas 4 , dois na extremidade $\mathrm{N}$-terminal e outros dois na extremidade C-terminal, não puderam ser modelados devido à ausência de densidade eletrônica. Todos os átomos presentes foram modelados dentro das densidades eletrônicas bem interpretadas, com exceção de algumas poucas cadeias laterais de resíduos, na maioria das vezes presentes na superfície dos monômeros e expostos ao solvente, cujas conformações não puderam ser modeladas. Nestes casos, a ocupação para tais átomos foi igualada a zero. 


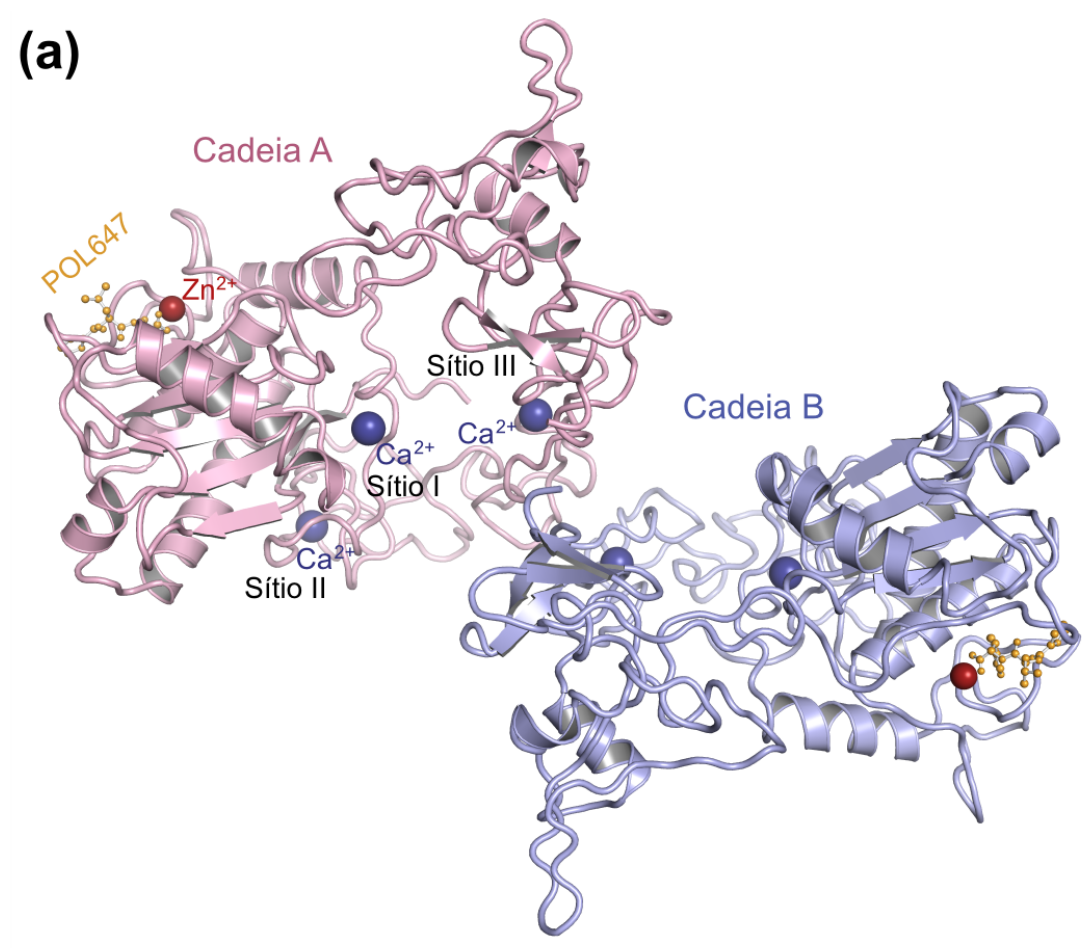

(b)
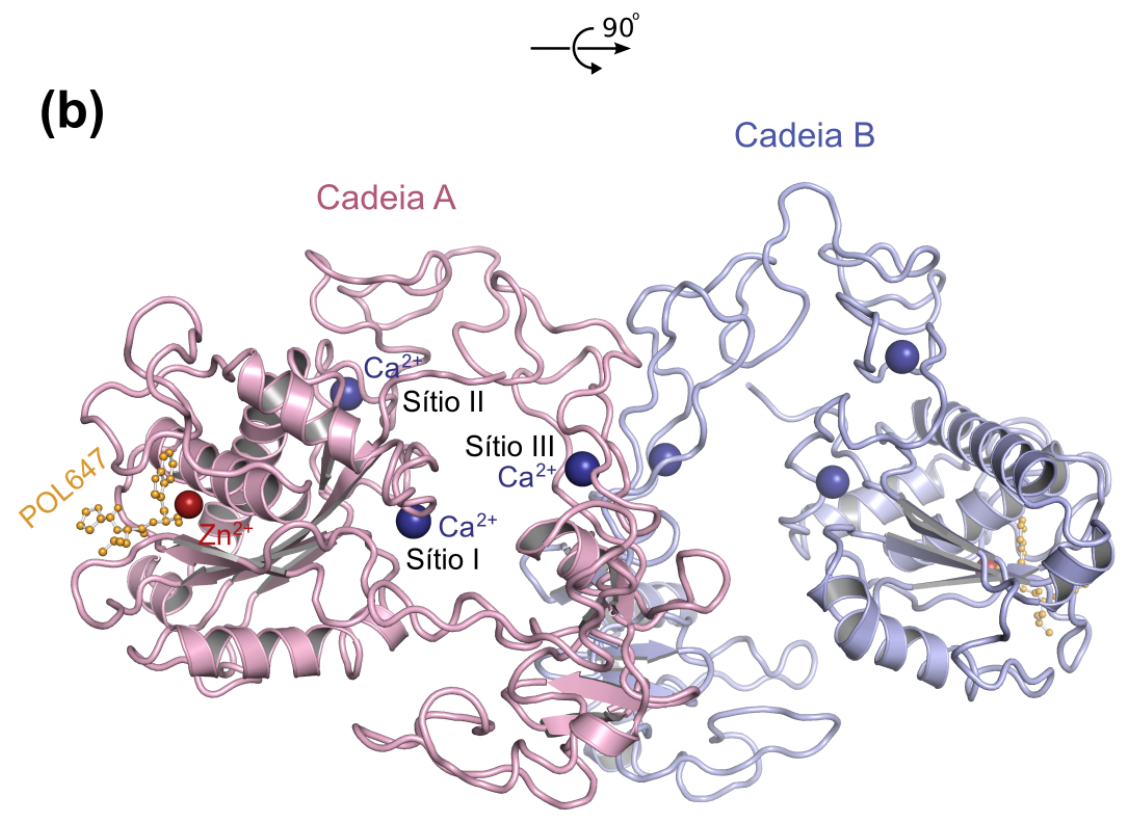

Figura 4.1: Composição da unidade assimétrica da célula unitária.

(a) O cristal de bothropasina tem, em sua unidade assimétrica, dois monômeros de bothropasina, formando um dímero cristalográfico. $\mathrm{O}$ eixo de simetria de ordem 2 passa perpendicularmente ao plano da folha, entre as cadeias A e B, no meio da figura. O inibidor POL647 está representado em "balls and sticks". Os íons de $\mathrm{Ca}^{2+}$ e $\mathrm{Zn}^{2+}$ estão representados por esferas azuis e vermelhas respectivamente. (b) Rotação de $90 \infty$ no eixo indicado pela seta em relação à figura (a). Figuras das estruturas feitas com o auxílio do programa PyMol (www.pymol.org). 
Devido à baixa resolução do conjunto de dados, o modelo foi refinado, inicialmente, com imposição de alta correlação por simetria não-cristalográfica (NCS) para todos os átomos, que foi liberado ao longo do processo de refinamento.

\section{Contatos intermoleculares no cristal}

A presença de duas moléculas, na unidade assimétrica, implica em uma quantidade de solvente no cristal de aproximadamente $50 \%$ do volume total, o que, associado às flexibilidades de algumas regiões na estrutura, assim como grandes canais de solvente internos e no empacotamento cristalino, contribuem para o baixo poder de difração dos cristais, possibilitando assim, uma maior desordem estática das moléculas.

A determinação e a descrição dos contatos intermoleculares foram feitas com o auxílio do servidor PISA ${ }^{3}$ (Krissinel e Henrick, 2005). Por esse servidor, pode-se calcular a área de contato entre os dois monômeros, descrever quais resíduos realizam contatos polares (ligações de hidrogênio e pontes salinas) e hidrofóbicos, além de se determinar a acessibilidade ao solvente de cada um dos resíduos presentes na superfície da estrutura. Também é calculada a probabilidade, que varia de 0 a 1 , de a interface analisada ter relevância na atividade biológica da proteína. Resumidamente, os contatos intermoleculares no cristal de bothropasina compartilham áreas pequenas (valor máximo de $973 \AA^{2}$ e mínimo de $92 \AA^{2}$ ) com baixos números de contatos polares (em média 8 por interface; figura 4.2), na unidade assimétrica. Esses valores de área de contato estão muito abaixo daqueles previstos como sendo funcionalmente importantes (em média $1400 \AA^{2}$, Lo Conte et al., 1999), e não devem representar um papel biológico.

3 http://www.ebi.ac.uk/msd-svd/prot_int/pistart.html. Acesso em 21 de junho de 2007. 


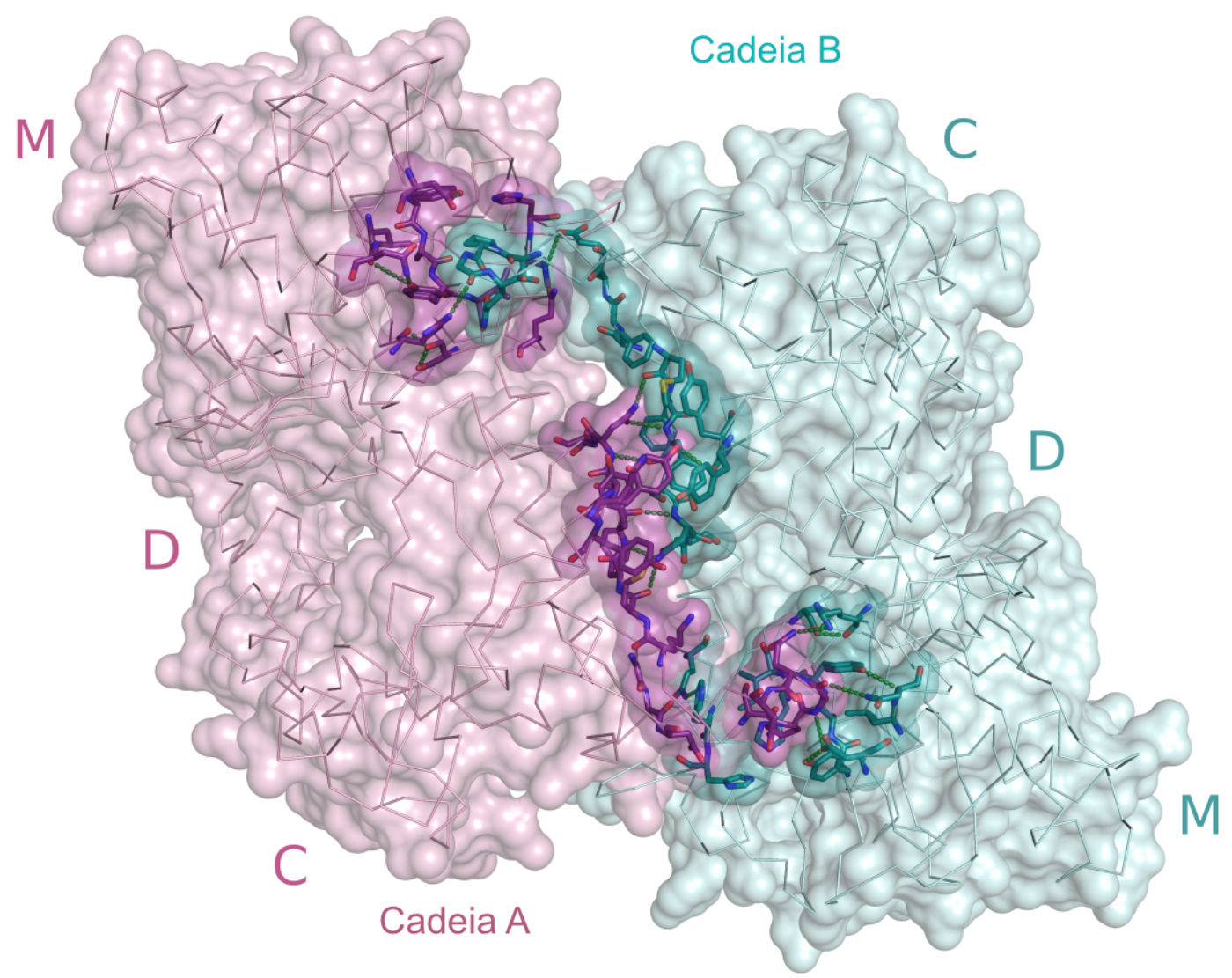

Figura 4.2: Contatos intermoleculares do cristal. As interações entre as duas moléculas se dão através de contatos polares (8 ligações de hidrogênio e uma ponte salina destacadas por linhas tracejadas na cor verde) e hidrofóbicos. As superfícies de van der Waals na região de interface estão destacadas em roxo (cadeia A) e azul (cadeia B) respectivamente. As cadeias A e B estão representadas por traços apenas para os átomos da cadeia principal e destacadas nas cores rosa e azul respectivamente. A superfície de van der Waals para os dois monômeros está em branco. M, D e C representam os domínios metaloprotease, desintegrina e rico em cisteína, respectivamente.

\section{Os domínios $M D C$}

A estrutura da bothropasina é composta pelos domínios: N-terminal Metaloproteinase (M), o domínio Desintegrina (D) e pelo domínio C-terminal Rico em Cisteína $(\mathrm{C})$, como esperado para proteínas pertencentes à classe P-III de SVMPs (figura 4.3). Devido à grande semelhança existente entre as cadeias $\mathrm{A}$ e $\mathrm{B}$, por simples convenção, a cadeia A foi adotada como referência no decorrer deste trabalho. 


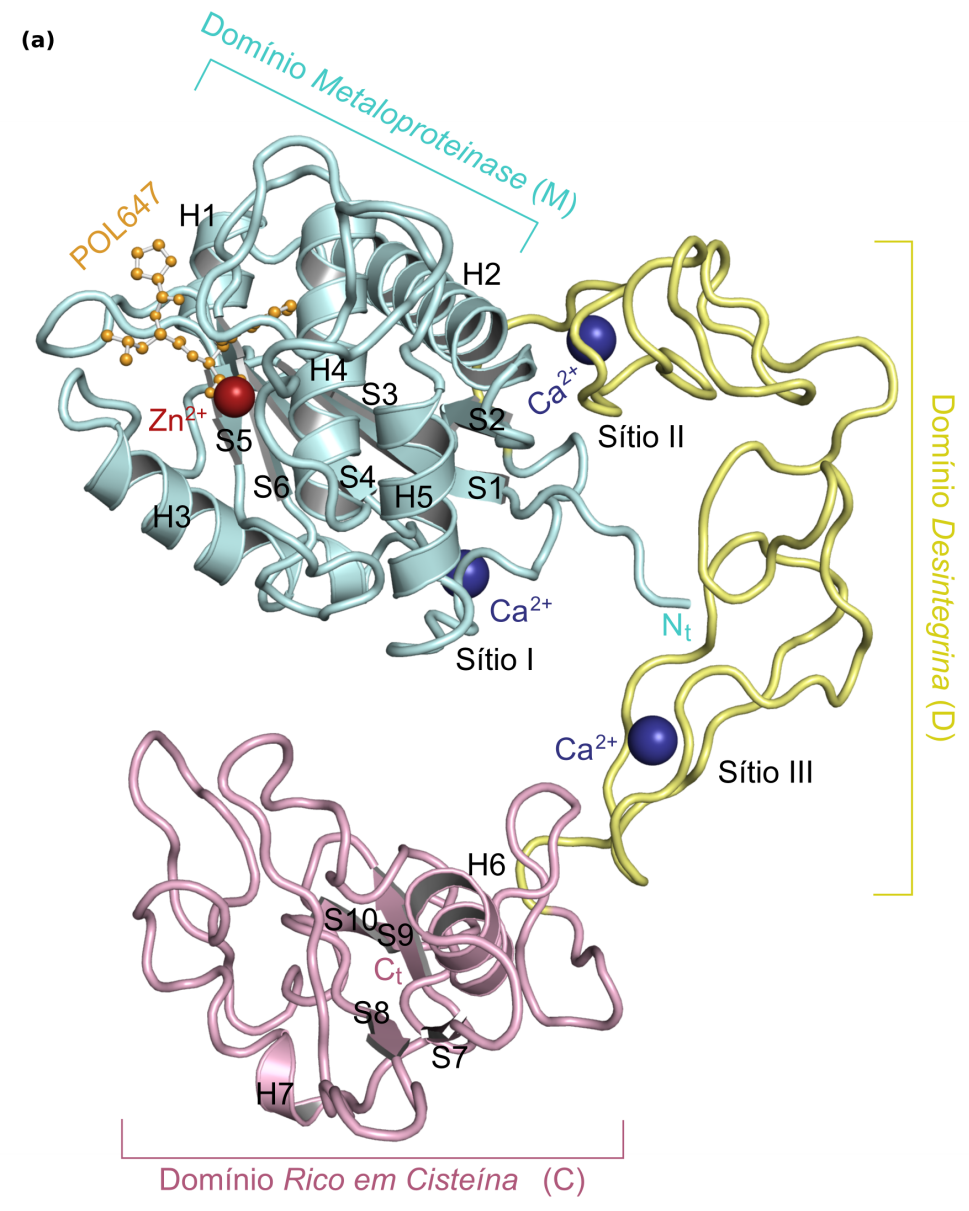

(b) Vista lateral

(c) Vista frontal
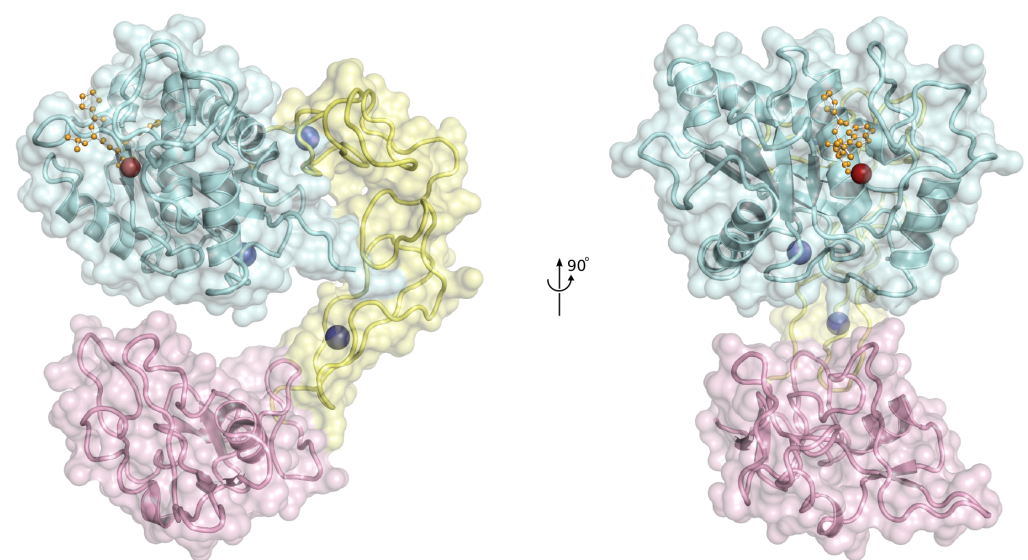

Figura 4.3: Estrutura da bothropasina complexada com o inibidor POL647. (a) Visão lateral da estrutura revelando a presença de três domínios: o domínio catalítico (M); o domínio desintegrina (D) e o domínio rico em cisteína (C). (b) Bothropasina disposta da mesma maneira que em (a) e superfície de van der Waals para ressaltar a formação de um bolsão no interior da estrutura. (c) Representação da estrutura da bothropasina rotacionada em $90 \infty$ em relação a (b) evidenciando, através da utilização da superfície de van der Waals a não interação existente entre o domínios $(\mathrm{M})$ e $(\mathrm{C})$, apesar de próximos. Os domínios $\mathrm{M}, \mathrm{D}$ e $\mathrm{C}$ estão representados nas cores azul ciano, amarela e rosa, respectivamente. 
O domínio D tem início nas proximidades da região de ligação do íon $\mathrm{Ca}^{2+}$ do domínio catalítico M (“Sítio I" na figura 4.3 (a)), ou seja, na parte oposta à região de ligação do $\mathrm{Zn}^{2+}$ e, conseqüentemente, do inibidor POL647 (figura 4.3 (a)). O domínio D, aliado ao domínio localizado na porção carbóxi-terminal da estrutura, o domínio $\mathrm{C}$, formam uma estrutura similar a um braço, em direção ao domínio $\mathrm{M}$. Apesar de próximos, os domínios $\mathrm{M}$ e $\mathrm{C}$ não realizam nenhum tipo de interação direta entre as cadeias laterais dos resíduos que os compõem (figura 4.3 (b) e (c)). Também merece ser destacada a presença de um significativo espaço no interior (cavidade) na estrutura. A presença desses espaços, aliados à falta de interação entre os domínios $\mathrm{M}$ e C garantem uma maior flexibilidade à estrutura, além de aumentar a porcentagem de solvente presente no empacotamento cristalino, colaborando com o baixo poder de difração e aumento da desordem e mosaicidade no cristal.

Cada monômero contem 35 resíduos de cisteína, sendo que 34 deles fazem pontes dissulfeto e possuem espaçamento estritamente conservado dentro da classe P-III de SVMP. O único resíduo que não forma ponte dissulfeto é a Cys189 que será apresentado em maiores detalhes no decorrer deste trabalho.

\section{O domínio M: sítio ativo, sítio de ligação do inibidor, cálcio e açúcar.}

O domínio $\mathrm{M}$ consiste em dois subdomínios em um arranjo muito similar àqueles descritos SVMPs da classe P-I como a adamalisina II e acutolisina (GomisRuth et al., 1993a; 1993b). O principal subdomínio apresenta uma arquitetura com motivo $\alpha / \beta$, formando uma folha $\beta$, composta por 5 fitas paralelas (fitas $\mathrm{S} 1,2,3,4$ e 6), e uma fita anti-paralela (fita S5). Além das fitas, o domínio também apresenta 4 hélices- $\alpha$ (H1, 2, 3 e 4). O menor subdomínio consiste em uma hélice- $\alpha$ (H5) e “loops" (figura 4.4). O motivo altamente conservado HExxHxxGxxH e a metionina conservada da "volta de metionina" Met169, característicos de membros das 
metazincinas (Gomis-Ruth et al., 1998), são encontrados no subdomínio principal (figura 4.4).

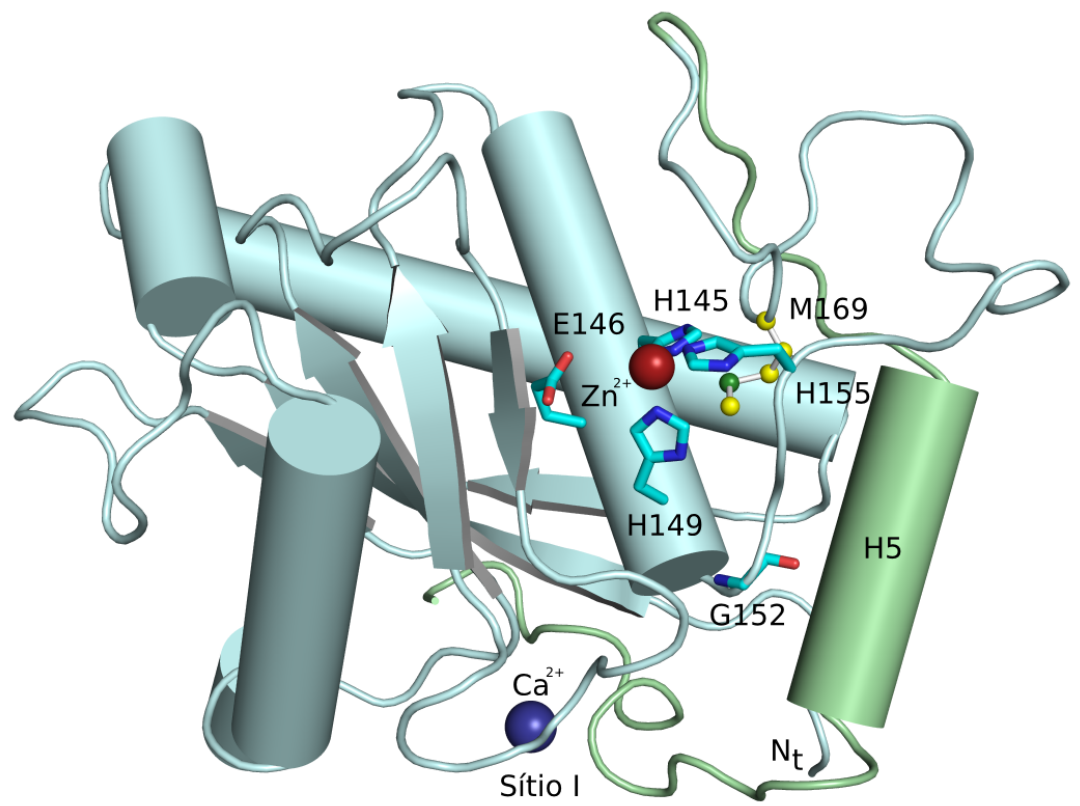

Figura 4.4: Domínio catalítico e seu subdomínio. Detalhe da região catalítica mostrando os resíduos altamente conservados na classe P-III de SVMPs " $\mathbf{H}_{145} \mathrm{E}_{146} \mathrm{Xx} \mathbf{H}_{149} \mathrm{XxG}_{152} \mathrm{XxH}_{\mathbf{1 5 5}}$ ", além da "volta de metionina" representada pelo resíduo M169 e a porção C-terminal do domínio M formado pela hélice- $\alpha$ H5 destacada em verde que se estende desde a região próxima ao sítio de coordenação do zinco, até a parte posterior do domínio, próximo ao sítio de ligação do cálcio.

O sítio ativo do domínio catalítico da bothropasina é muito similar aos observados em SVMPs da classe P-I (figura 4.5). O íon zinco apresenta uma coordenação pentaédrica formada pelos átomos N\&2 das histidinas 145, 149 e 155 do motivo $\mathbf{H}_{145} \mathrm{E}_{146} \mathrm{XXH}_{149} \mathrm{XXG}_{152} \mathrm{XXH}_{155}$ e por dois oxigênios presentes no grupo carboxílico do inibidor POL647 (figura 4.5) de maneira similar ao observado na adamalisina II complexada com o mesmo inibidor (Gomis-Ruth et al., 1998). 


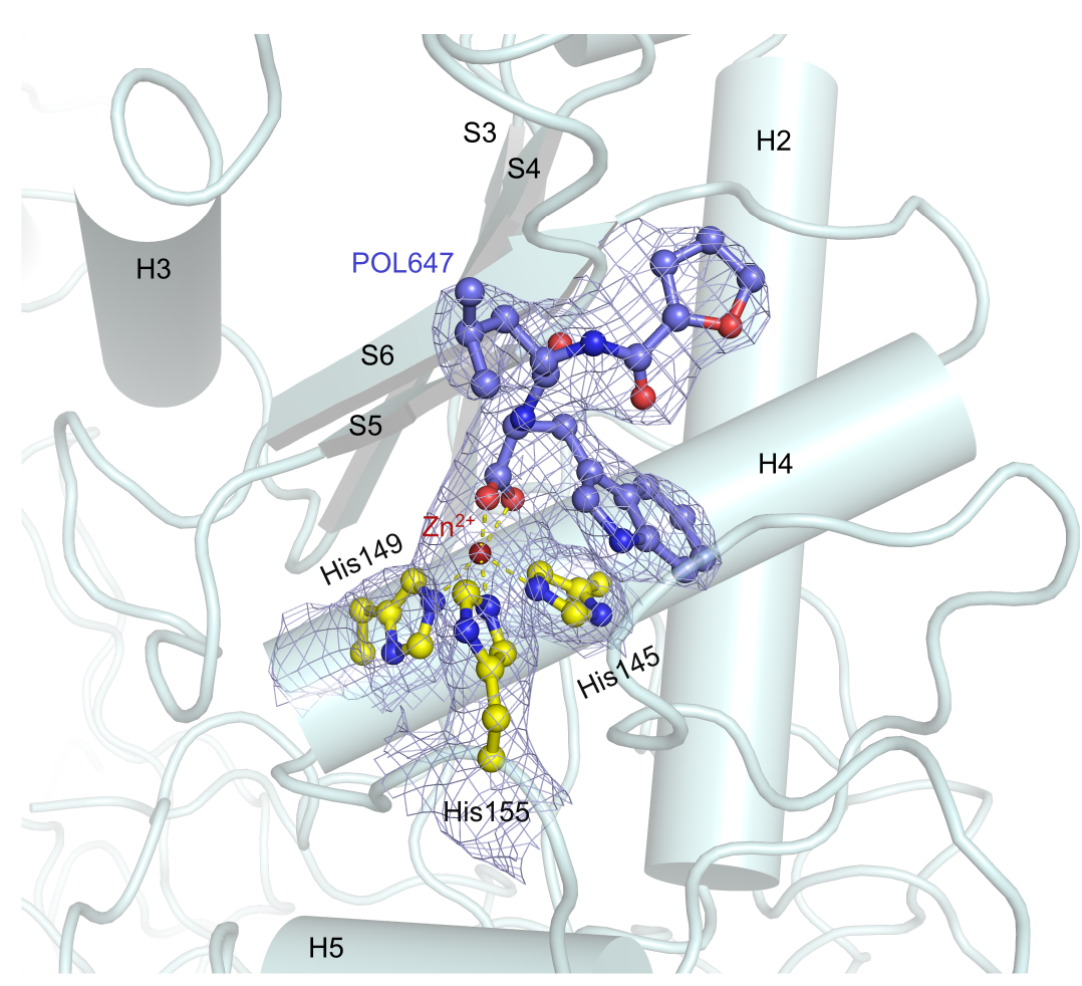

Figura 4.5: Sítio de ligação ao zinco. Detalhe mostrando os resíduos envolvidos na coordenação pentaédrica do íon zinco (esfera vermelha) e o inibidor não específico POL647 (representado em "balls and sticks" na cor azul) presente no sítio catalítico. O mapa de densidade eletrônica $\left(2 \mathrm{~F}_{\text {obs }}-\mathrm{F}_{\text {calc }}\right)$ é traçado e contornado a $1 \sigma$.

Estruturas de proteínas da classe P-I de SVMPs, obtidas na ausência do inibidor, mostram o íon zinco coordenado por três histidinas e uma molécula de água (Gomis-Ruth et al., 1993b; Gong et al., 1998) e a cadeia lateral de uma tirosina fazendo o papel do quinto ligante (Bode et al., 1992).

O mapa de densidade eletrônica mostra a presença de um íon cálcio na superfície do domínio M, localizado ao lado oposto do sítio ativo. Esse íon, tem sido relacionado à estabilização da folha $\beta$ que contém o $\mathrm{N}$-terminal. $\mathrm{Na}$ bothropasina, o íon cálcio está coordenado por um átomo de oxigênio, proveniente da cadeia lateral do Glu12 e Asn203, dois átomos de oxigênio da Asp96 e pelo grupo carbonil da Cys200 (figura 4.6). 


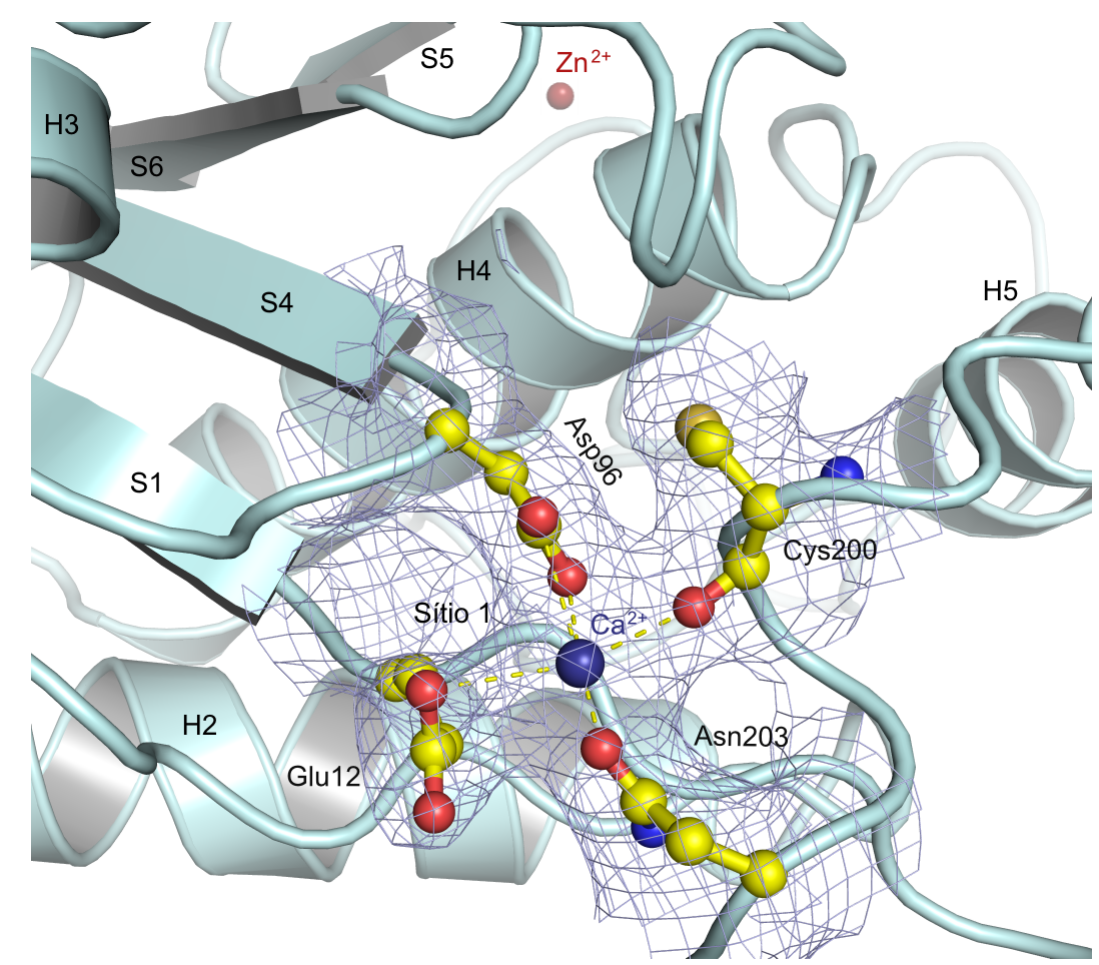

Figura 4.6: Sítio I de ligação ao cálcio do domínio M. Detalhe da coordenação do íon $\mathrm{Ca}^{2+}$ (esfera azul) pelos resíduos representados em "balls and sticks" localizados na parte oposta ao sítio de ligação ao zinco (parte superior central da figura).

O domínio catalítico da bothropasina ainda é provido de 7 resíduos de cisteína, sendo que 6 deles realizam pontes dissulfeto: Cys120-Cys200, Cys160Cys184 e Cys162-Cys167 (figuras 4.11 e 4.12). A possibilidade do resíduo de cisteína livre, no domínio catalítico, ser responsável por interações inter-domínios ou inter-moleculares foi afastada pela observação de que o resíduo de cisteína livre, Cys189, é circundado por resíduos hidrofóbicos e livre de qualquer possibilidade de interações com outras moléculas ou domínios (figura 4.7). Uma observação semelhante foi feita na estrutura da acutolisina (Gong et al., 1998) e para a VAP2B (Igarashi et al., 2007). 


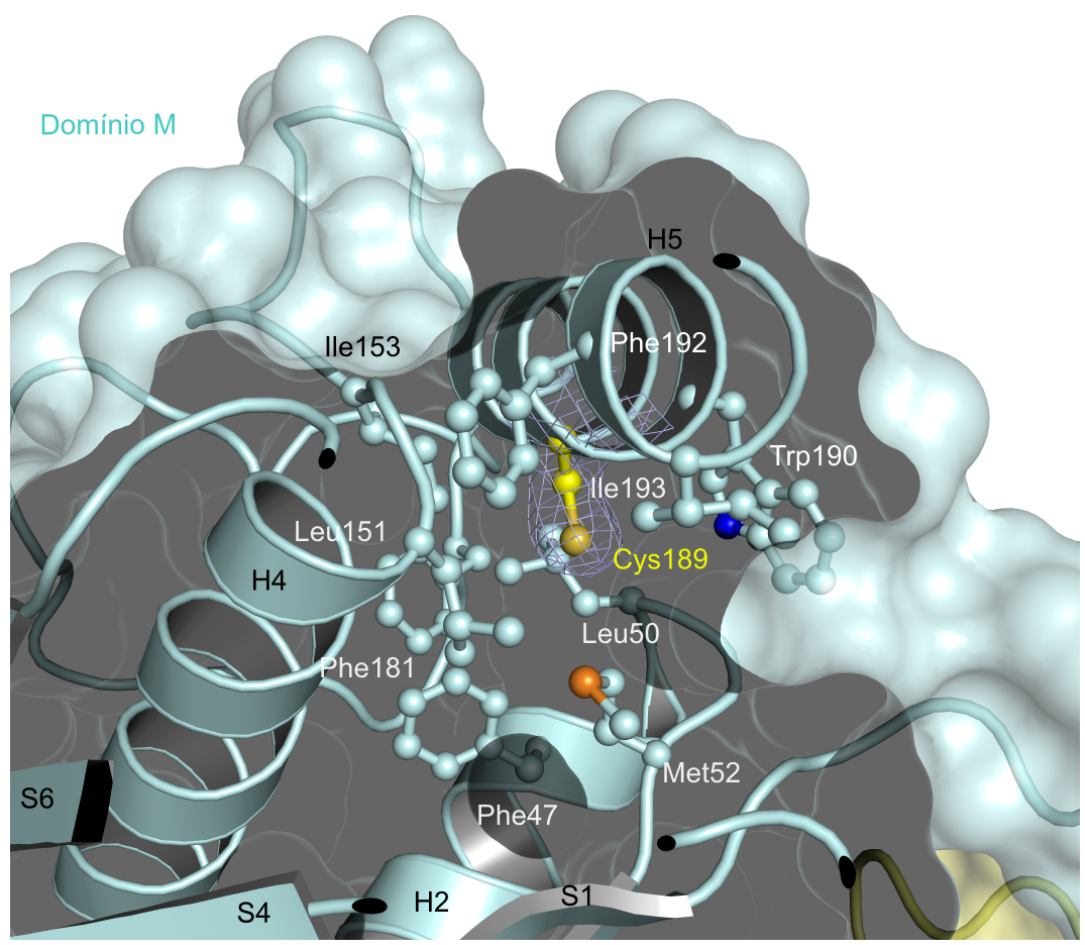

Figura 4.7: Domínio catalítico evidenciando a cisteína livre 189. O domínio catalítico $\mathrm{M}$ está representado em "cartoon" envolto por um gráfico de superfície de van der Waals para enfatizar a impossibilidade de interação do resíduo Cys189 em uma possível formação de ponte dissulfeto. A Cys 189 é circundada por resíduos hidrofóbicos formando uma espécie de barreira e tornando-a inacessível ao meio externo.

\section{Região de ligação ao açúcar}

A glicosilação de proteínas para formar glicoproteínas é um processo importante, pois promove alterações nas propriedades protéicas como estabilidade, solubilidade e volume físico. Os carboidratos em glicoproteínas também atuam como sinais de reconhecimento, essenciais no processo de direcionamento protéico e para o reconhecimento celular de proteínas e de outras células. Há dois tipos de glicosilação: a nitrogênio-glicosilação (N-glicosilação), que ocorre no nitrogênio da amida de cadeias laterais de asparagina e a oxigênio-glicosilação (O-glicosilação), que ocorre no hidróxi-oxigênio de serina e treonina. O processo da $\mathrm{N}$-glicosilação é concomitante à tradução, isto é, ocorre enquanto a proteína está sendo sintetizada e, 
assim, pode afetar o enovelamento da proteína. O processo de O-glicosilação ocorre após a tradução e apenas sobre proteínas totalmente enoveladas.

É descrito na literatura que metaloproteases de venenos são moléculas glicosiladas. Na estrutura da bothropasina foi encontrada densidade eletrônica suficiente para acomodar uma molécula de açúcar, provavelmente o N-acetil glucosamina (NAG), ligada ao resíduo Asn183 (figura 4.8), caracterizando, portanto, a ocorrência de N-glicosilação.

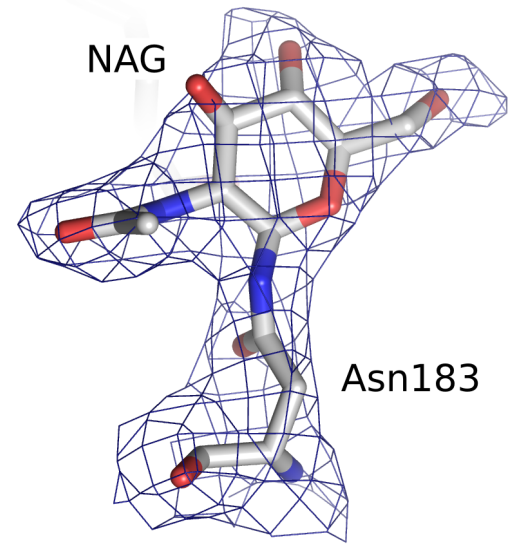

Figura 4.8: Molécula de NAG presente na estrutura cristalográfica. Uma molécula de NAG foi modelada na densidade eletrônica da bothropasina na região de glicosilação.

Foi observada uma densidade eletrônica de maior tamanho, no sítio de ligação ao NAG, indicando que outros açúcares poderiam ser adicionados à molécula de NAG como, por exemplo, manoses e glicoses, porém, dada a qualidade da resolução, não foi possível a identificação dessas moléculas.

\section{O domínio tipo-desintegrina (D)}

O início do domínio $\mathrm{D}$ foi definido de acordo com evidências experimentais, a partir de dois trabalhos independentes. O seqüenciamento da região N-terminal da jararagina-C nativa (Usami et al., 1994) e ALT-C (Souza et al., 2000), duas proteínas derivadas do processo proteolítico, contendo apenas os domínios DC, 
evidenciaram exatamente a mesma seqüência em seu N-terminal: IISPPVCGNELLEV. A primeira isoleucina, corresponde a Ile210, presente também na região espaçadora.

O domínio desintegrina não apresenta estruturas secundárias bem definidas, sendo formado, exclusivamente, por "loops" estabilizados por pontes dissulfeto e também pela presença de dois íons de cálcio encontrados nos sítios de ligação II e III (figura 4.9 (a)). O cálcio no sítio II, localizado no início do domínio D, é coordenado por átomos de oxigênio dos resíduos Val215, Gln218, Leu220, Glu222, Glu225 e Asp228 (figura 4.9 (b)). O Asp228 está incluído no primeiro motivo ECD altamente conservado na classe P-III das SVMPs, e cuja função nunca foi investigada.

O domínio desintegrina apresenta um alto conteúdo de resíduos de cisteínas, e 7 pontes dissulfeto são encontradas: Cys216-Cys245, Cys227-Cys240, Cys229-Cys235, Cys239-Cys262, Cys253-Cys259, Cys258-Cys284, Cys271-Cys291 (Figura 4.9 (a)). Uma surpreendente observação ficou por conta de uma ponte dissulfeto inter-domínios entre a Cys278 e Cys310, conectando os domínios D e C. A Cys278 pertence ao segundo motivo ECD da estrutura, o qual tem sido demonstrado estar envolvido na ligação à integrina (Jia et al., 1997). Este motivo ECD está localizado em um "loop" e é estruturalmente relacionado à região RGD de desintegrinas-RGD, derivadas das P-II SVMPs. Nessas proteínas, o "loop" é qualificado como importante para que a ligação com as integrinas seja estabelecida (McLane et al., 1998). 
(a)

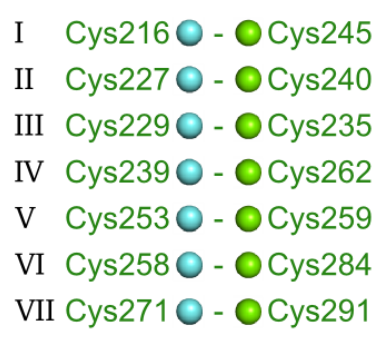

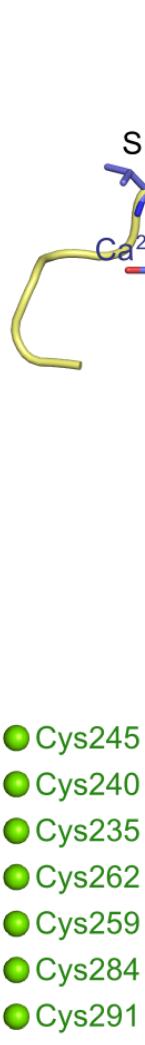
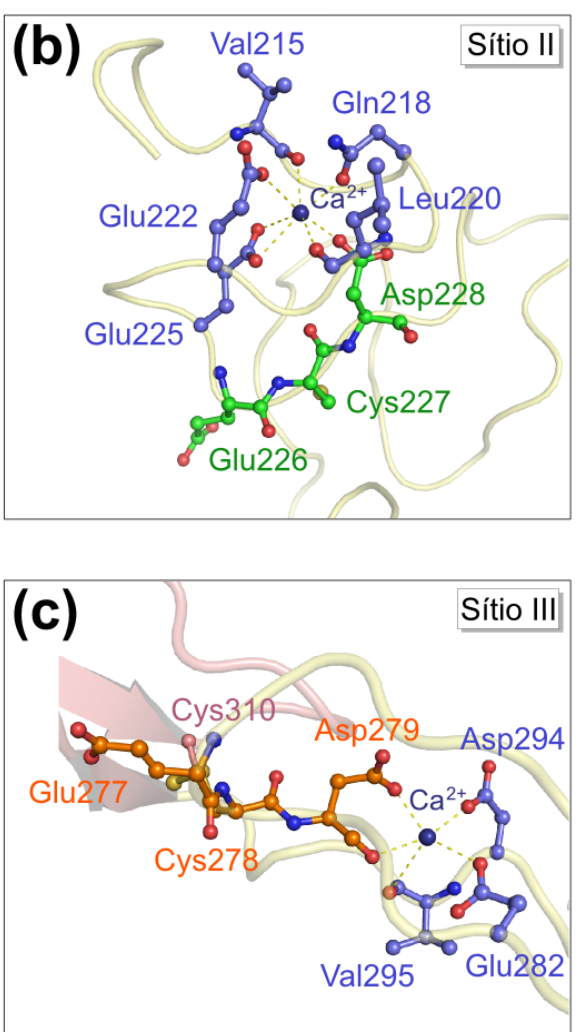

Figura 4.9: A estrutura do domínio tipo-desintegrina (D). (a) Resíduos envolvidos na coordenação do íon $\mathrm{Ca}^{2+} \mathrm{e}$ as pontes dissulfeto representadas por esferas azul ciano e verde, numeradas de acordo com a legenda no canto inferior esquerdo da figura (a). Os íons de cálcio estão representados como esferas azuis. Os "loops" desintegrina (ECD I e II) estão em verde e alaranjado respectivamente. $\mathrm{O}$ início do domínio (C) aparece na cor rosa. Os resíduos responsáveis pela coordenação dos íons $\mathrm{Ca}^{2+}$ aparecem nas figuras (b) e (c). Em (c), duas moléculas de água que coordenam o $\mathrm{Ca}^{2+}$ não foram mostradas.

Em bothropasina, o motivo ECD é também encontrado em uma região estruturalmente desorganizada, a qual é estabilizada pela ponte dissulfeto Cys278Cys310 e também por um íon $\mathrm{Ca}^{2+}$ presente no sítio III (figura 4.9 (c)). A cadeia lateral do Glu277 do motivo ECD está exposto ao solvente e, portanto, poderia ser importante em um processo de reconhecimento e/ou garantir especificidade a ligantes.

O cálcio no sítio III é coordenado por dois átomos de oxigênio do Asp279, do domínio ECD, um átomo de oxigênio do Asp294 e um átomo de oxigênio do Glu282 e da cadeia principal da Val279 (figura 4.9 (c)). 
Recentemente, a estrutura de uma metaloprotease/desintegrina de veneno de Crotalus atrox foi determinada (Takeda et al., 2006). Os autores sugerem que o domínio D poderia ser dividido em mais dois subdomínios, o "ombro" (domínio $\mathrm{D}_{\mathrm{s}}$ ) e o domínio "braço" (domínio $\mathrm{D}_{\mathrm{a}}$ ) que constitui a região estrutural rígida (Takeda et al., 2006). Os autores sugerem que o "loop" desintegrina, que contém o motivo ECD, é inacessível à interações. Embora a exata função do motivo ECD ainda permaneça controversa, alguns trabalhos têm mostrado interações do motivo ECD das P-III SVMPs e ADAMs com algumas integrinas (Jia et al., 1997; Gichuhi et al., 1997; Ramos et al., 2007).

\section{O domínio rico em cisteína $(C)$}

Apesar da notação de "rico em cisteína", o domínio C possui um número menor de cisteínas que o domínio $\mathrm{D}$, assim como uma razão número de aminoácidos/número de cisteínas também inferior ao domínio D. A denominação "rico em cisteína" pode ser explicada pelo fato de diferentes autores tentarem dividir os domínios embasados na seqüência de aminoácidos e não a partir da estrutura cristalográfica.

Estabeleceu-se o início do domínio C como sendo a partir da seqüência de aminoácidos QPCLDN, baseado no C-terminal de desintegrinas RGD desprovidas do domínio C (Calvete et al., 2000; Kamiguti et al., 2003; Fox e Serrano, 2005; Pinto et al., 2007). Apesar da ausência natural do domínio $\mathrm{C}$, formas ativas recombinantes têm sido produzidas para homólogas à bothropasina, como, por exemplo, a atrolisina A (Jia et al., 2000; Serrano et al., 2005). Atrolisina A é capaz de inibir a agregação plaquetária simulada por colágeno e interagir com células MG-63, a fim de inibir a adesão ao colágeno. Esses dados sugerem um papel funcional ao domínio rico em cisteína da classe P-III. 
O domínio C é constituído por 118 resíduos e é composto por duas hélices- $\alpha\left(\right.$ Met $_{318}-\mathrm{Phe}_{326}$ e $\left.\mathrm{Asp}_{335}-\mathrm{Phe}_{338}\right), 4$ pequenas fitas $\beta\left(\mathrm{Gly}_{300}-\mathrm{Cys}_{303} ; \mathrm{Tyr}_{307}-\right.$ $\mathrm{Cys}_{310}, \mathrm{Lys}_{407}-\mathrm{Ser}_{410}$; $\mathrm{His}_{413}-\mathrm{Asp}_{416}$ ) e o restante da estrutura é composto por “loops" (figura 4.10). A presença de pontes dissulfeto é importante para garantir a estabilização desses "loops". Um total de 6 pontes dissulfeto é encontrada neste domínio ( $\mathrm{Cys}_{303}-\mathrm{Cys}_{315}, \mathrm{Cys}_{322}-\mathrm{Cys}_{372}, \mathrm{Cys}_{337}-\mathrm{Cys}_{383}, \mathrm{Cys}_{350}-\mathrm{Cys}_{360}, \mathrm{Cys}_{367}-\mathrm{Cys}_{409}$, Cys $_{403}-\mathrm{CyS}_{413}$; figura 4.10).

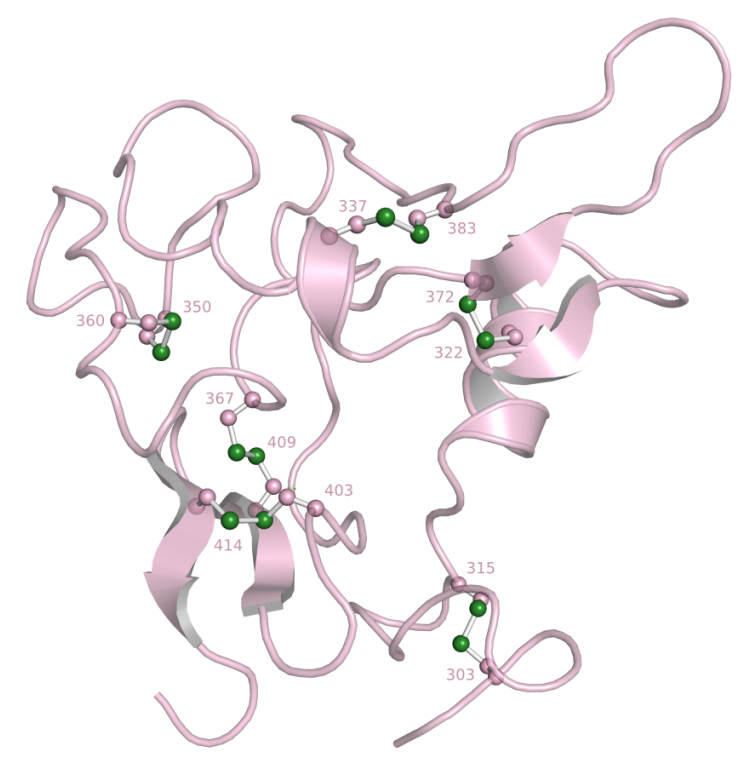

Figura 4.10: Pontes dissulfeto no domínio rico em cisteína. Representação em "cartoon" do domínio rico em cisteína e suas pontes dissulfeto representadas em "balls and sticks". Os 12 resíduos de Cys formadores de 6 pontes dissulfeto estão numerados.

As pontes dissulfeto da catrocolastatina-C, uma proteína tipodesintegrina, derivada da catrocolastatina, uma P-III SVMP de Crotalus atrox, foram determinadas bioquimicamente (Calvete et al, 2000). Foi estabelecido que o domínio tipo-desintegrina apresenta 8 pontes dissulfeto e que o domínio rico em cisteína apresenta 6, e nenhuma ponte dissulfeto inter-domínios foi relatada. A estrutura da bothropasina apresenta um padrão de pontes dissulfeto diferente do relatado para a catrocolastatina, sendo verificada uma ponte dissulfeto entre os domínios D e C, 
constituída pelos resíduos Cys278-Cys310. Este resultado pode justificar o fato do processo proteolítico liberar somente uma molécula contendo os domínios DC e não ser encontrada uma molécula constituída somente do domínio C. Interessantemente, a estrutura da catrocolastatina (Igarashi et al., 2007) mostra um padrão de pontes dissulfeto semelhante ao encontrado para bothropasina, porém os autores não discutem esses resultados.

\section{As figuras 4.11 e 4.12 ilustram as pontes dissulfeto na estrutura} tridimensional, e na estrutura primária da bothropasina.

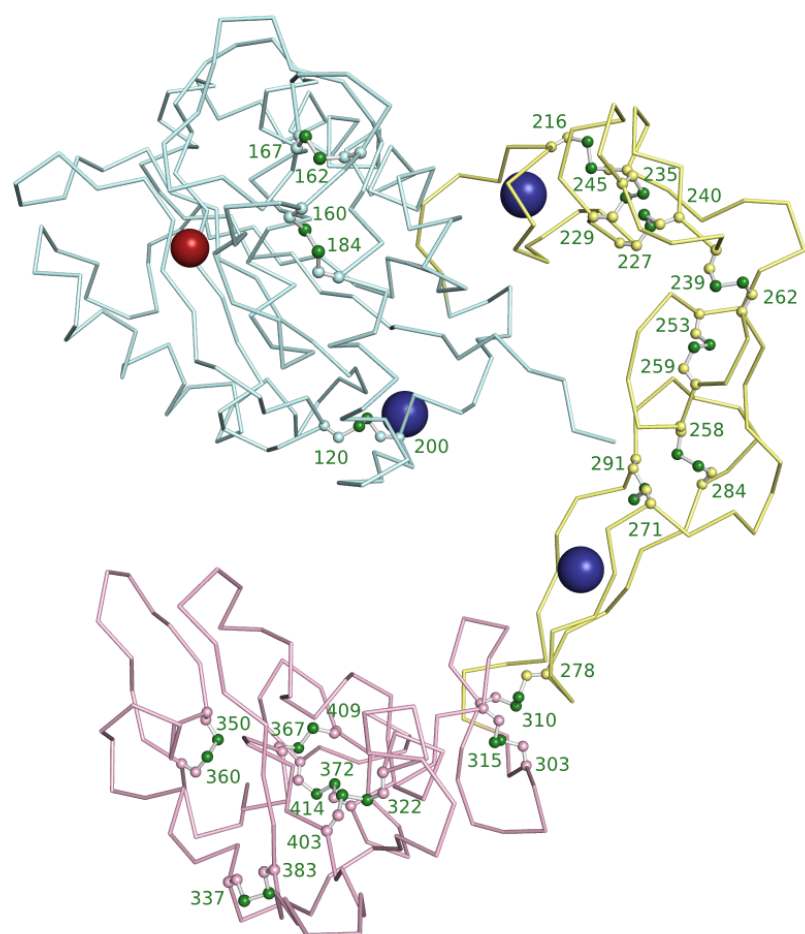

Figura 4.11: Distribuição das pontes dissulfeto por toda a estrutura da bothropasina. As 17 pontes dissulfeto estão representadas em "balls and sticks" e numeradas. O zinco e o cálcio ligados ao domínio M, assim como os cálcios ligados ao domínio D estão representados por esferas nas cores vermelha e azul respectivamente. Os domínios $\mathrm{M}$, D e C estão representados nas cores azul ciano, amarela e rosa, respectivamente. 


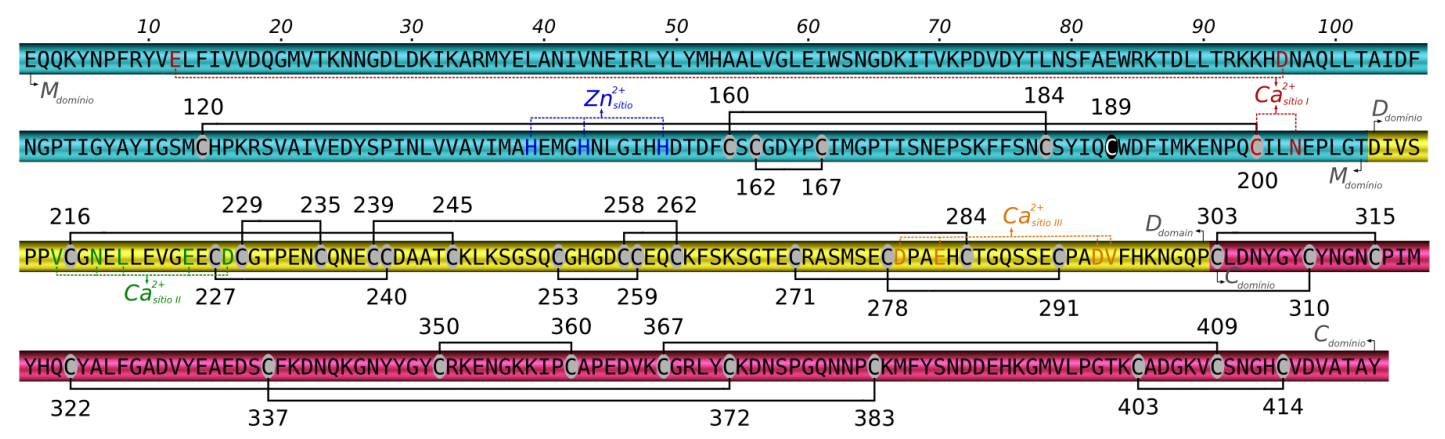

Figura 4.12: Seqüência de aminoácidos da bothropasina mostrando os padrões de pontes dissulfeto para os domínios $\mathrm{M}$, D e C respectivamente. Os resíduos formadores de pontes dissulfeto estão destacados em cinza, numerados e conectados por linhas contínuas. A cisteína livre 189 está destacada em preto. Os sítios de ligação ao cálcio I, II e III assim como o de ligação ao zinco estão indicados.

\section{Jararagina vs Bothropasina}

Durante décadas, acreditava-se que a jararagina fosse a proteína predominante no veneno de Bothrops jararaca e que, por um método de purificação estabelecido por Paine (1992), a obtenção da proteína P-III tratava-se sempre da jararagina.

Graças à aplicação da técnica de cristalografia de proteínas, empregada neste trabalho, foi possível uma comparação entre as estruturas tridimensionais das proteínas obtidas pelo método de Paine (1992) e pelo inédito protocolo de purificação desenvolvido e estabelecido nos experimentos já apresentados nesta tese.

Como descrito no Capítulo 3, de posse da estrutura refinada da bothropasina, foi possível o tratamento de um conjunto de imagens de difração de raios $\mathrm{X}$ coletado em meados do ano 2000 de um cristal supostamente formado pela proteína jararagina a fim de se checar a estrutura da proteína. A análise inicial mostra um modelo com grande similaridade estrutural à bothropasina descrita nesta tese.

Durante o processo de refinamento da estrutura com dados coletados em 2000, diversas regiões apresentaram as mesmas diferenças pontuais da bothropasina em relação aos resíduos a serem modelados, quando comparados aos da jararagina. 
Essas diferenças eram fortemente acusadas, tanto pelas densidades eletrônicas do mapa diferença $\left(\mathrm{F}_{\mathrm{obs}}-\mathrm{F}_{\text {calc }}\right)$, quanto pelo mapa pesado $\left(2 \mathrm{~F}_{\mathrm{obs}}-\mathrm{F}_{\text {calc }}\right)$. Como pode ser visualizado na figura 4.13, o primeiro cristal era constituído puramente de bothropasina.

Além da indubitável certeza da correta seqüência através da inspeção dos mapas de densidades eletrônicas, outro fato que merece atenção é a quase inexistente diferença do ponto isoelétrico teórico (pI) e massa molecular entre as duas proteínas. Os pontos isoelétricos calculados para as proteínas são: 5,08 e 5,05 para jararagina e bothropasina, respectivamente. Suas massas moleculares são de 48,85 e 48,74 kDa para jararagina e bothropasina, respectivamente.

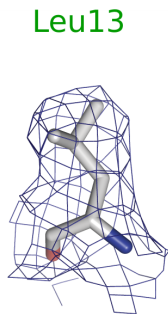

Leu47
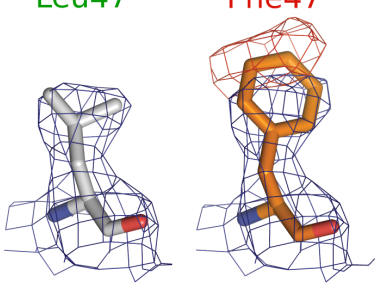

Phe159

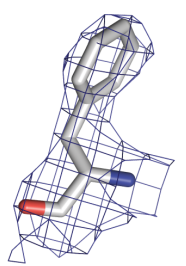

Met21 Thr21
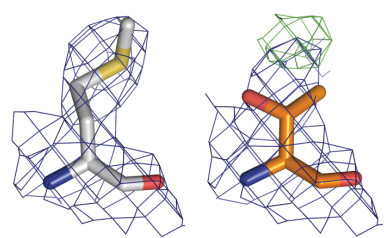

Asp158

Gly158
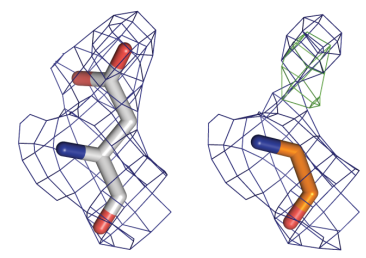

Ser159

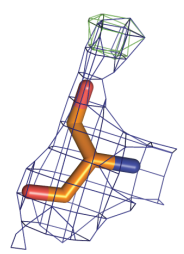

Figura 4.13: A densidade eletrônica e os verdadeiros resíduos. Dentre as 19 diferenças sugeridas no seqüenciamento através do mapa de densidade eletrônica, os 5 melhores representantes são mostrados nesta figura. À esquerda, em verde, estão os resíduos, de bothropasina, corretamente atribuídos dentro das densidades e, à direita, em vermelho, os resíduos supostamente atribuídos, baseados na seqüência da jararagina. $\mathrm{O}$ mapa $2 \mathrm{~F}_{\mathrm{obs}}-\mathrm{F}_{\text {calc }}$ está em azul e o mapa diferença, contornado com valores para sigma iguais a 3 e -3 estão representados em verde e vermelho respectivamente. 
Com base nas informações supracitadas, verifica-se a dificuldade de se obter e garantir que a proteína de interesse seja jararagina ou bothropasina, independente do método de purificação empregado. Uma das maneiras de se aferir qual proteína foi purificada, seria através do seqüenciamento da proteína por degradação de Edman ou através de espectrometria de massas. Entretanto, o emprego dessas técnicas ao final de todo o processo de purificação seria muito laborioso e inviável. Além disso, o seqüenciamento da região N-terminal é impossibilitado por apresentar-se bloqueado.

Uma vez que dois experimentos, baseados em protocolos totalmente distintos de purificação e cristalização, resultaram na obtenção da estrutura cristalográfica da mesma proteína, pode-se então considerar que a forma protéica de maior concentração encontrada no extrato bruto do veneno da serpente $B$. jararaca é a bothropasina e não a jararagina.

\section{Comparação estrutural com outras P-III SVMPs}

Até 2006 não havia nenhuma estrutura de SVMPs da classe P-III conhecida. O grupo que determinou a primeira estrutura tridimensional publicou, recentemente, a estrutura de mais uma SVMP, ambas do veneno de Crotalus atrox (Takeda et al., 2006; Igarashi et al., 2007). A VAP1 é uma metaloprotease/desintegrina dimérica e a VAP2B1 é monomérica.

Neste trabalho, estruturas que apresentam os domínios M, D, DC e MDC (um total de 14 estruturas), foram comparadas à molécula de bothropasina com a finalidade de se observar onde as maiores mudanças conformacionais estão localizadas. As sobreposições estruturais foram realizadas com o auxílio do programa LSQMAN (Kleywegt e Jones, 1994).

As orientações relativas, de alguns subdomínios, mostraram-se bastante 
divergentes quando alinhados estruturalmente. As maiores diferenças foram observadas quando o domínio M das P-III SVMPs VAP1 e VAP2B são sobrepostos. As partes $\mathrm{N}$ - e C-terminais dos domínios D e C da bothropasina mostram-se rotacionadas em, aproximadamente, $20 \infty, 40 \infty$ e chegando até a $70 \infty$ nas extremidades do domínio C, resultando em um deslocamento de até $26 \AA$ em sua terminação distal (figura 4.14 (a) e (b)).

(a)

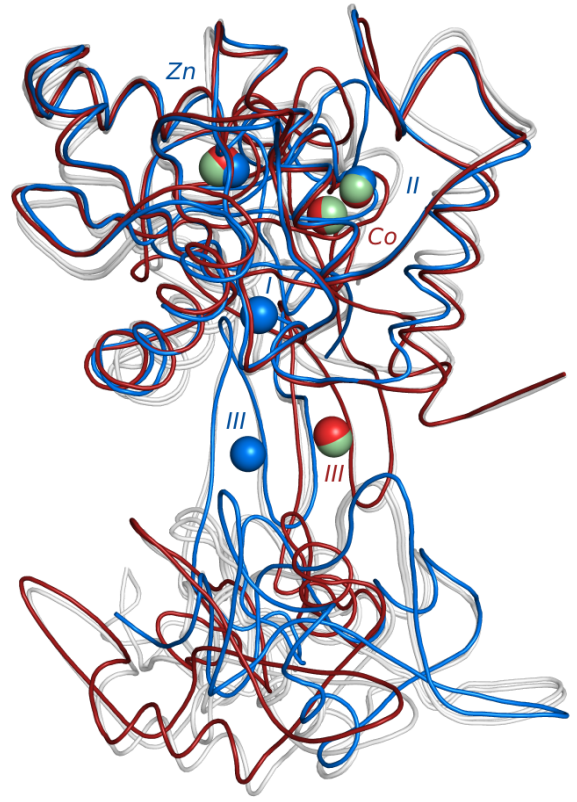

(b)

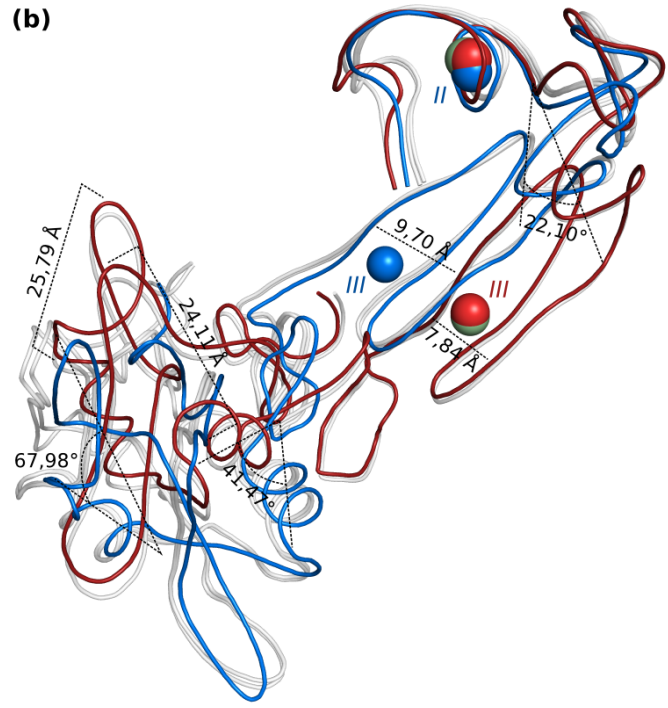

Figura 4.14: Mobilidade dos domínios D e C em diferentes P-III SVMPs. (a) Os domínios M, D e C de duas P-III SVMPs estão destacados nas cores azul e vermelho: bothropasina e VAP1 respectivamente. Outros representantes de SVMPs estão na cor cinza claro. Os íons $\mathrm{Ca}^{2+}$ e $\mathrm{Zn}^{2+}$ estão representados por esferas para um melhor discernimento das regiões em questão. Esferas azuis, vermelhas e verdes representam os íons para os sítios de ligação das proteínas: bothropasina, VAP1 e VAP2B respectivamente. Nota-se que tanto a VAP1 como VAP2B (uma das estruturas em cinza) possuem um íon $\mathrm{Co}^{+2}$ no domínio $\mathrm{M}$, próximo à região de ligação ao cálcio na bothropasina. (b) Superposição dos domínios D e C de P-III SVMPs. A partir do sítio II de ligação ao $\mathrm{Ca}^{2+}$, os domínios $\mathrm{D}$ e $\mathrm{C}$, apesar de estruturalmente equivalentes, adotam uma bifurcação. $\mathrm{O}$ reflexo de tal bifurcação fica ainda mais evidenciado no domínio $C$, com ângulos de rotação de até $70 \infty$ entre as estruturas da bothropasina e VAP1.

$\mathrm{Na}$ sobreposição do domínio $\mathrm{C}$ das estruturas, verifica-se o inicio de deslocamentos a partir da Leu220 que se estende até o resíduo Gly250 (figura 4.15), 
que é conservado em todas as P-III SVMPs analisadas. Toda a região entre os sítios de ligação aos íons cálcio (sítio I e II) apresenta uma leve movimentação em conseqüência da rotação dos ângulos da cadeia principal do resíduo Val215 (figura 4.15). A partir do resíduo Gly250, a sobreposição dos domínios mostra que ocorre uma 'bifurcação', ou seja, que a posição C-terminal do domínio D é deslocada ao longo da cadeia (figura 4.15).

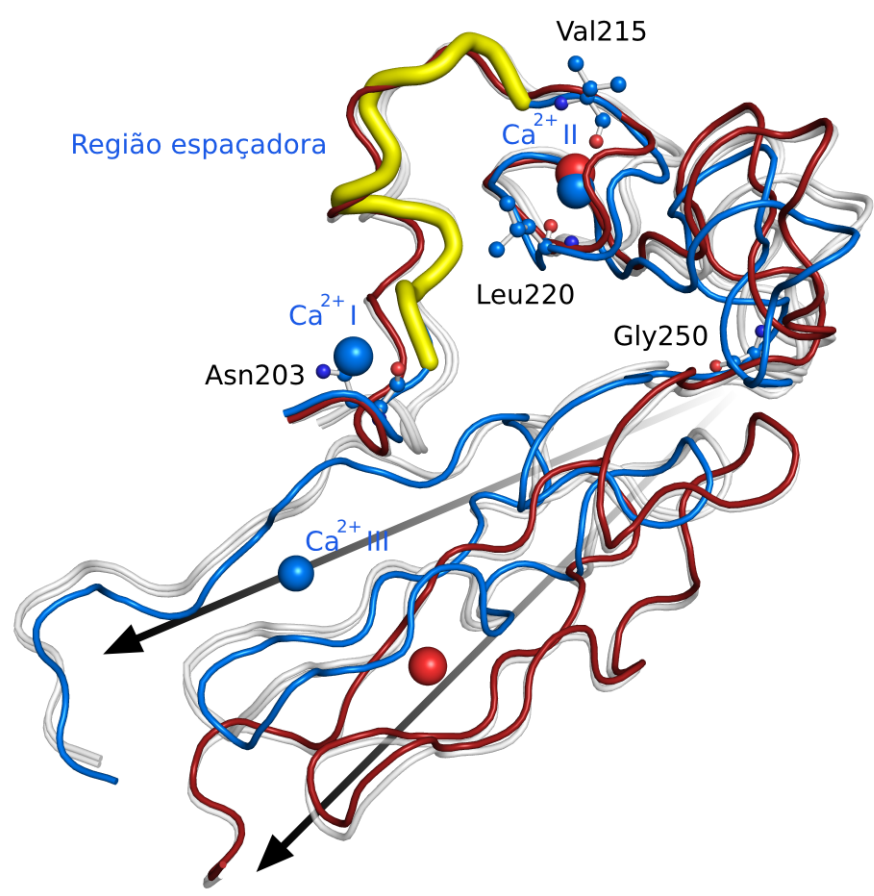

Figura 4.15: Val215 e Leu220 como moduladores da movimentação estrutural. A Val215, que participa da coordenação do cálcio no sítio II, separa a região espaçadora destacada em amarelo da região onde ocorrem as maiores torções nas cadeias principais na porção N-terminal do domínio D. A Gly250, por se tratar de um resíduo bastante flexível, é o responsável pelo início da divergência estrutural adotada por essa classe de proteínas. As setas indicam que, a partir da Gly250, as estruturas adotam diferentes direções, mostrando-se fundamental para efetivação desse processo. As cores das esferas azuis e vermelhas representam os íons para os sítios de ligação das proteínas bothropasina e VAP1 respectivamente, assim como suas estruturas tridimensionais.

Durante o processo de movimentação da região espaçadora $\left(\mathrm{Asn}_{203^{-}}\right.$ $\mathrm{Val}_{215}$ ), a cadeia lateral do resíduo Leu220 no domínio D aparece posicionada em um ponto articulador (figuras 4.16 (a) e (b)). O átomo oxigênio da cadeia principal do 
resíduo Leu220 é um dos que coordenam o íon $\mathrm{Ca}^{2+}$ no sítio II, e sua cadeia lateral proeminente na porção N-terminal do domínio D interage com uma pequena cavidade hidrofóbica na superfície do domínio M (figura 4.16 (a)).

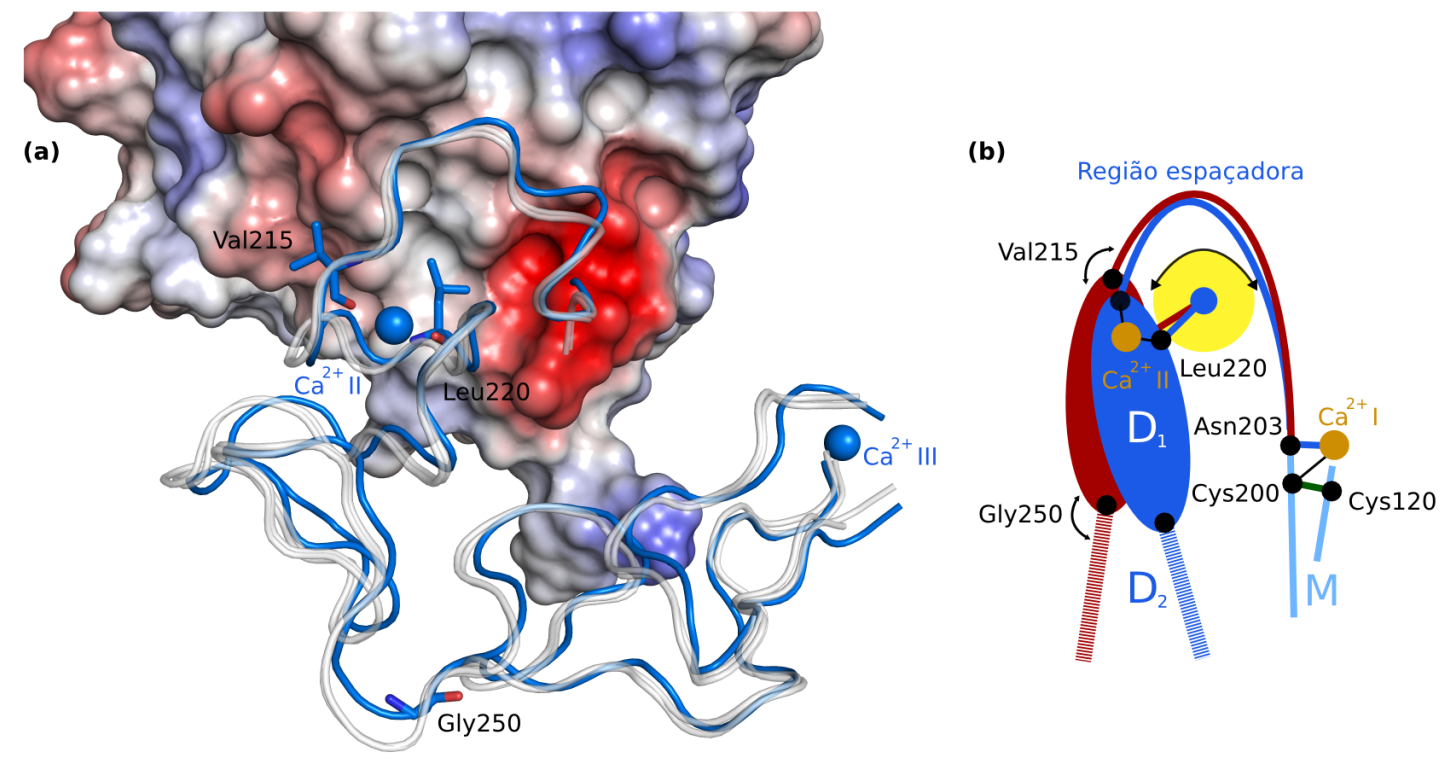

Figura 4.16: Papel articulador da Leu220. (a) Detalhe da região hidrofóbica entre a cadeia lateral da Leu220 e o domínio catalítico. A superfície molecular do domínio $\mathrm{M}$ está colorida de acordo com sua superfície de potencial eletrostático (do vermelho (-) ao azul (+)). A estrutura da bothropasina está destacada na cor azul e duas catrocolastatina estão na cor cinza claro. Os cálcios são representados por esferas azuis e os resíduos chaves estão representados em "stick". (b) Diagrama esquemático da movimentação tipo dobradiça na junção da região espaçadora e porção $\mathrm{N}$-terminal do domínio desintegrina. $\mathrm{O}$ domínio $\mathrm{D}$ foi subdividido em $\mathrm{D}_{1}$ e $\mathrm{D}_{2}$ com a finalidade didática. $\mathrm{D}_{1}$ representa a região bastante flexível $\mathrm{Cys}_{216}-\mathrm{Ser}_{249}$. $\mathrm{D}_{2}$ é a região Cterminal do domínio desintegrina. Esquema adaptado de Igarashi et al., 2007.

Outras cadeias laterais de aminoácidos hidrofóbicos como Leu, Phe, Ile ou Val, são encontrados nessa mesma posição articuladora, nas famílias das ADAM e SVMPs (figuras 4.17 e 4.19). A cadeia lateral desses resíduos poderia atuar como uma junta, permitindo a parte superior do domínio D adotar várias orientações em relação ao domínio M. A região espaçadora realiza poucas interações específicas com a parte superior do domínio $\mathrm{D}$, garantindo, assim, um certo grau de liberdade para movimentação. 
A região espaçadora $\left(\mathrm{N}_{203}\right.$ EPLxTDIVSPPV $\left.{ }_{215}\right)$ é altamente conservada nas mais diversas famílias de metaloproteases, como pode ser observado na figura 4.17. A região atua primariamente como elo entre os domínios $\mathrm{M}$ e $\mathrm{D}$ e poderia exercer o papel de modulador dos movimentos e orientação do domínio M em relação ao resto da molécula, visando a uma melhor adaptação da estrutura na interação com diferentes alvos. Com esta vasta quantidade de regiões flexíveis espalhadas por toda a molécula da bothropasina, assim como em estruturas homólogas, pode-se especular que toda essa flexibilidade intrínseca seja importante para um melhor ajuste no reconhecimento e especificidade a um substrato.

A verdadeira função dessas regiões flexíveis, assim como todo o processo de reconhecimento de substratos e adesão ainda necessitam ser elucidados com o auxílio, por exemplo, de técnicas espectroscópicas, microscopia eletrônica de complexos protéicos e estruturas de complexos proteína-ligantes.

\section{Análise seqüencial comparativa entre bothropasina e outras P-III SVMPs}

É sugerido na literatura que um "loop" no domínio C da catrocolastatina, denotado como "Hiper Variable Region", HVR, seja a região de reconhecimento/especificidade dos ligantes e, portanto, importante para a atividade da proteína (Takeda et al., 2006).

Uma análise comparativa de 41 seqüências de aminoácidos de proteínas da classe P-III de SVMPs, disponíveis no banco de dados $\mathrm{NCBI}^{4}$, foi feita com a finalidade de se obter informações adicionais a partir da estrutura primária dessas proteínas (figura 4.17). As seqüências foram alinhadas com auxílio do programa MULTIALIGN (Corpet, 1988) e árvores filogenéticas foram construídas utilizandose o pacote de programas PHYLIP (Felsenstien, 1989).

4 www.ncbi.nlm.nih.gov. Acesso em 03 de junho de 2007. 
O domínio pró-enzima mostrou-se altamente conservado, assim como o sítio de ligação ao zinco no domínio catalítico. Em estudos anteriores, foi demonstrado que os domínios ativos foram mais susceptíveis a uma acelerada evolução que os domínios regulatórios, os quais, provavelmente, geraram subfamílias distintas de proteínas com diferentes atividades biológicas ou especificidade (Moura-da-Silva et al., 1996b). Análises preliminares de árvores filogenéticas mostraram que as classes P-III de SVMPs podem ser subdivididas em diversos agrupamentos protéicos (figura 4.18). 


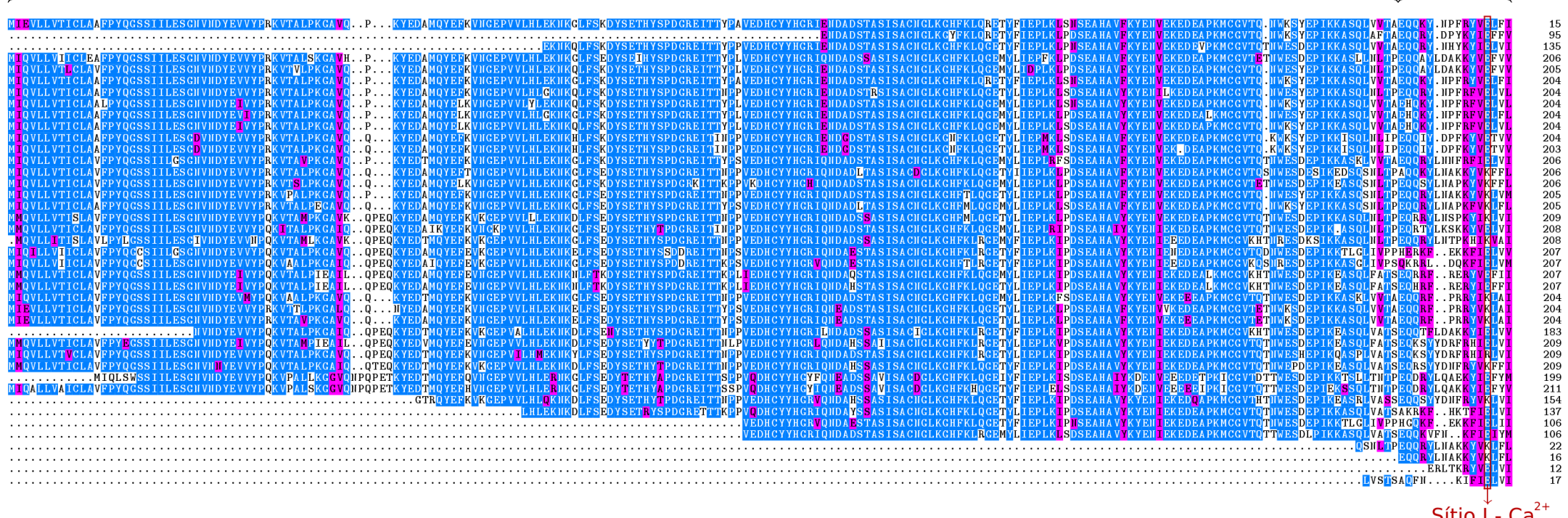

Domínio metaloprotease (M)

Domínio tipo desintegrina (D)

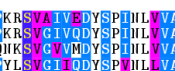

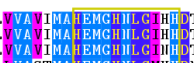

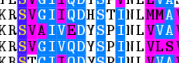

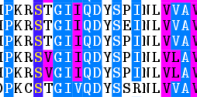




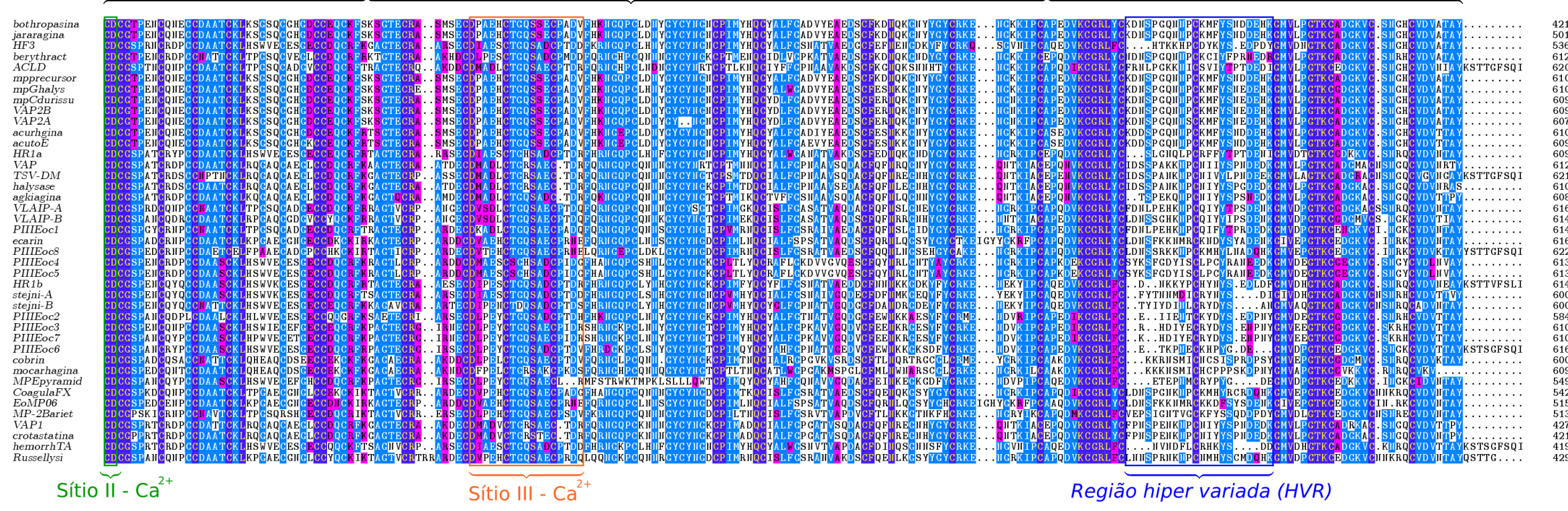

Figura 4.17: Alinhamento seqüencial de P-III SVMPs. Um total de 41 P-III SVMPs foram alinhadas. O alinhamento destaca uma boa similaridade entre todas as seqüências. O domínio pró-enzima é altamente conservado, assim como o número e espaçamento entre as cisteínas, sítios de ligação ao cálcio e de ligação ao zinco. As seqüências foram obtidas no banco de dados NCBI e são listadas da seguinte maneira: jararagina (NA: P30431); bothropasina (NA: AAC61986.2); metaloproteinase precursor de B. insularis (NA: AAM09693.1); metaloproteinase P-III de C. durissus durisus (NA: ABA42117.1); VAP2B de C. atrox (NA: AAC59672.1); metaloprotease de G. halys (NA: AAD02652.1); acuragina precursor de D. acutus (NA: AAS57937.1); acutolysina-E precursor de D. acutus (NA: Q9W6M5); VAP2A de C. atrox (NA: BAF56420.1); HF3 de B. jararaca (NA: AAG48931.5); HR1b de T. flavoviridis (NA: P20164); toxina hemorrágica de $C$. atrox (NA: AAA03326.1); HR1a de T. flavoviridis (Q8JIR2); stejnihagin-A de $V$. stejnegeri (NA: ABA40760.1); stejnihagin-B de V. stejnegeri (NA: ABA40759.1); berythractivase de B. erythromelas (NA: AAL47169.1); ACLD de A. controtrix laticinctus (NA: AAC18911.1); VAP1 de C. atrox (NA: BAB18307.1); crotastatina de C. durissus terrificus (NA: ABB42830.1); VAP de T. flavoviridis (NA: BAB60682.1); TSV-DM de V. stejnegeri (NA: ABC73079.1); halysase de G. halys (JC8056); agkihagina de D. acutus (NA: ABB79955.1); VLAIP-A de M. lebetina (NA: AAX38181.1); VLAIP-B de M. lebetina (AAX38182.1); P-III SVMP de E. ocellatus 1 (NA: CAJ01679.1); Ecarina precursor de E. carinatus (NA: Q90495); P-III SVMP de E. ocellatus 8 (NA: CAJ01680.1); P-III SVMP de E. ocellatus 4 (NA: CAJ01685.1); P-III SVMP de E. ocellatus 5 (CAJ01684.1); P-III SVMP de E. ocellatus 2 (NA: CAJ01688.1); P-III SVMP de E. ocellatus 3 (NA: CAJ01683.1); P-III SVMP de E. ocellatus 7 (NA: CAJ01682.1); P-III SVMP de E. ocellatus 6 (NA: CAJ01687.1); cobrina precursor de N. naja (NA: AAF00693.1); mocarhagina 1 de N. mossambica mossambica (NA: AAM51550.1); metaloprotease de E. pyramidum (NA: CAA55566.1); CoagulaFX de M. lebetina (NA: Q7T046); EoMP06 de E. ocellatus (NA: AAP92424.1); MP-2 de B. arietans (NA: AAX86634.1) and Russellysina de D. russellii 


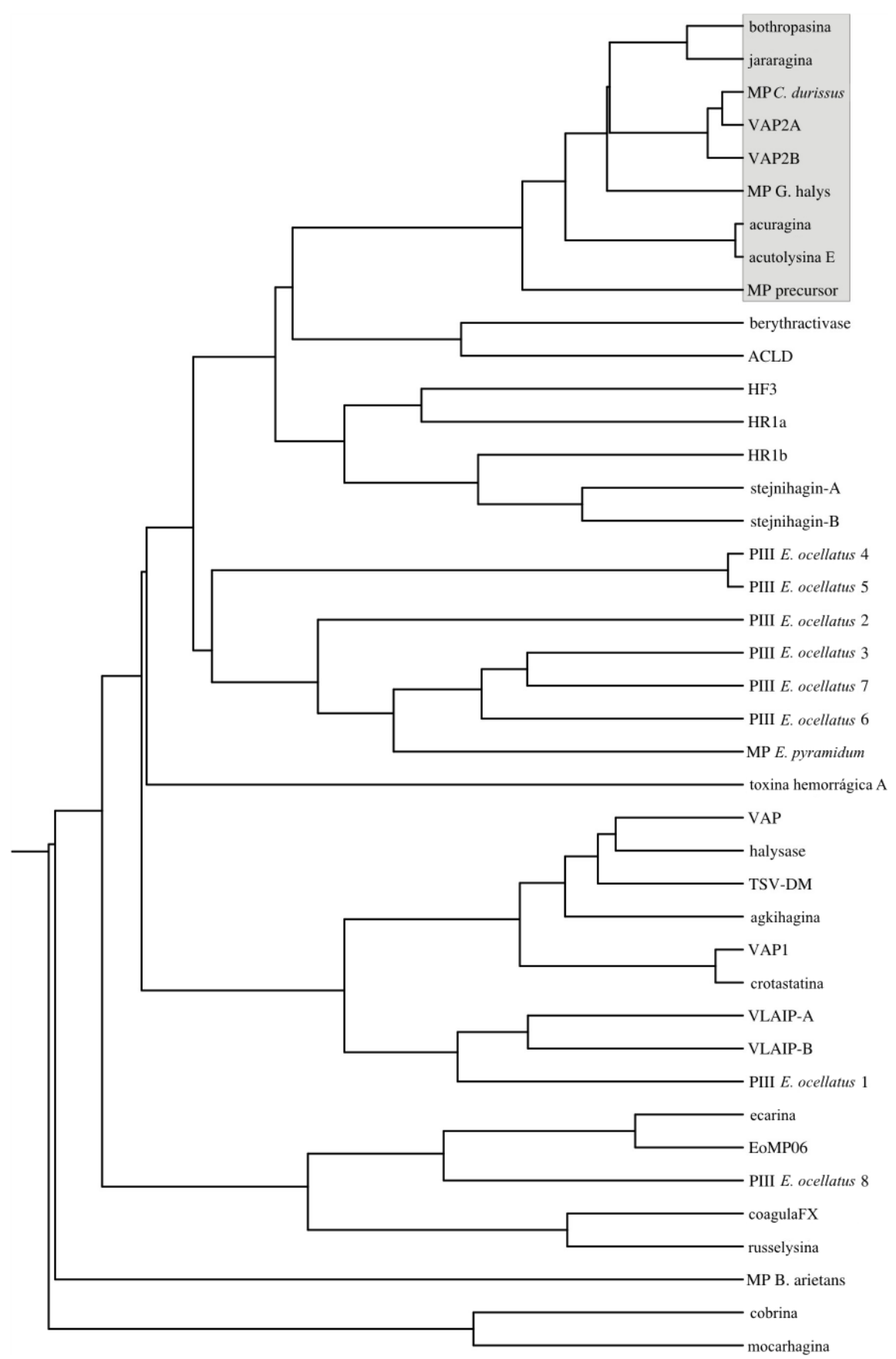

Figura 4.18: Árvore filogenética de P-III SVMPs. As seqüências de 41 P-III SVMPs foram obtidas como descrito na legenda da figura 4.17. O alinhamento seqüencial foi submetido ao programa ProtDist (parte do pacote de programas PHYLIP) para o cálculo das matrizes de distância a partir da estrutura primária e análises do tipo "Neighbor-joining" (NJ) através do método UPGMA de agrupamento com o intuito de inferir as relações entre as seqüências. O subgrupo formado pela bothropasina, jararagina, metaloproteinase de $C$. durissus, VAP2A, VAP2B, metaloprotease de G. halys, acuragina, acutolisina $\mathrm{E}$ e metaloprotease de B. insulares está destacado. 
A análise dos alinhamentos das seqüências mostra que a HVR não é encontrada em todas as proteínas. Ao contrário, observamos que as proteínas podem ser divididas em dois grupos, o constituído por proteínas com o HVR e o grupo de proteínas que apresentam esta região altamente variável, região denominada, neste trabalho, de "Highly Conservated Region", HCR. Exemplos de proteínas dos dois grupos são mostrados na figura 4.19 .

(a)

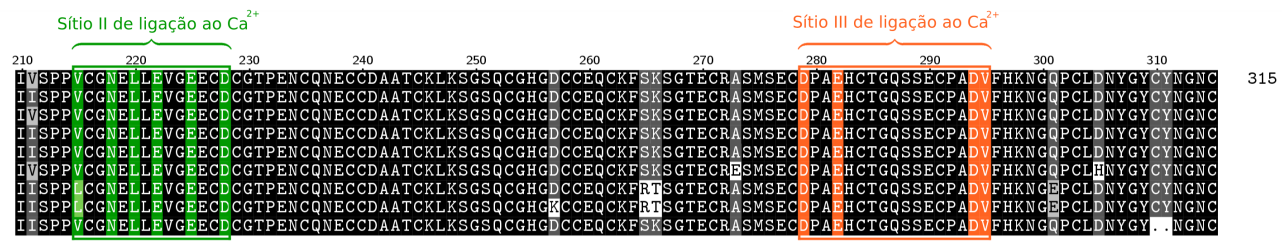

bothropasina

jararagina
mpprecursor

mpprecursor

catroco- $V$ A
mpGhalys

acuragina
acutolisina
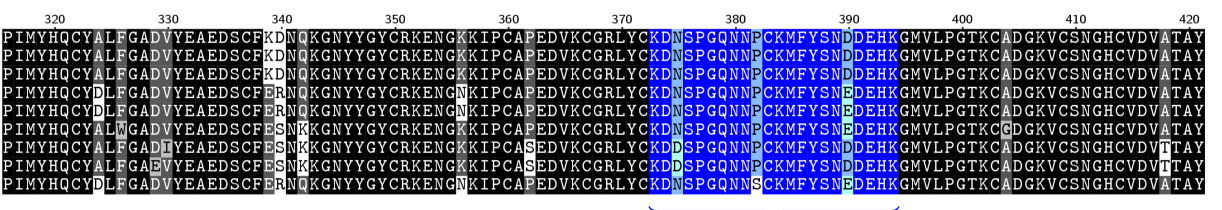

Região Hiper Conservada (RHC)
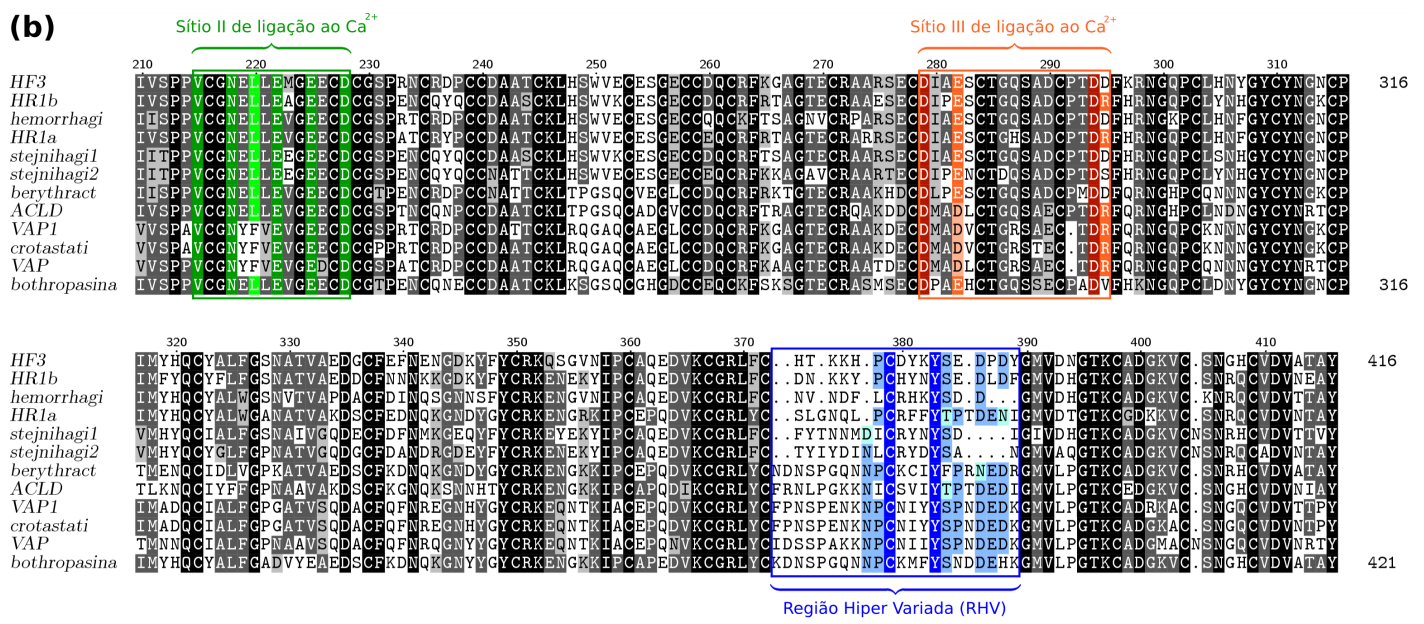

Figura 4.19: Alinhamentos de SVMPs em grupos I e II. (a) Os domínios DC de bothropasina alinhados a 8 proteínas homólogas e seus fortemente conservados sítios de ligação ao cálcio II e III e a região altamente conservada destacados nas cores verde, alaranjada, azul e suas nuances respectivamente compõem o grupo I. (b) Alinhamento entre proteínas provenientes de diferentes grupos mostram uma baixa conservação do domínio RHV quando comparadas com proteínas pertencentes ao mesmo grupo. Os sítios de ligação ao cálcio II e III e a região RHV seguem o mesmo padrão de cores de (a) e compõem o grupo II. Os números de acesso (NA) para as seqüências estão descritos na legenda da figura 4.17. 
A bothropasina é agrupada com outras 8 homólogas, incluindo a jararagina, VAP2A e VAP2B mas não VAP1 (figura 4.19 (a)). Pode ser observado que a região conhecida como "Hyper Variable Region” (HVR; resíduos 373-394), é altamente conservada nesse grupo da bothropasina e muito diferente do grupo da VAP1 (figura 4.19 (b)).

Baseado nessas observações, pode-se concluir que a chamada região hiper variada é variada apenas entre os grupos I e II, e não dentro do mesmo grupo. Entretanto, se essas proteínas que compartilham alto grau de similaridade seqüencial também compartilham especificidades biológicas similares, diferentemente dos outros subgrupos, ainda necessita ser elucidado.

Tem sido proposto que o HVR está envolvido no reconhecimento do alvo em um processo de ataque proteolítico do domínio M (Takeda et al., 2006). Essa hipótese, embora muito provável, ainda necessita de uma comprovação experimental. Por essa razão, aqui é proposto a classificação das SVMPs em dois subgrupos: PIIIHCR e PIII-HVR, de acordo com a identidade dos domínios DC. Esta classificação introduzirá uma maior complexidade a essa classe de proteínas desde a primeira proposta de classificação, baseada em processamento dos domínios DC (Fox e Serrano, 2005).

Uma importante observação diz respeito ao alto grau de conservação dos resíduos envolvidos na coordenação dos íons $\mathrm{Ca}^{2+}$ nos sítios II e III presentes no domínio DC (figuras 4.19 (a) e (b)). Apesar de pequenas variações em outras regiões ao longo das seqüências, o alto nível de conservação dos sítios de ligação ao cálcio indica, fortemente, que os dois íons $\mathrm{Ca}^{2+}$ são necessários para assegurar função à desintegrina. Interessantemente, um motivo ECD é encontrado em cada um dos sítios de coordenação de cálcio. O segundo motivo ECD tem sido demonstrado estar 
envolvido na ligação à integrina que dispara uma resposta de sinalização intracelular, mediada pela integrina (Kamiguti et al., 1999; Mariano-Oliveira et al., 2003).

As proteínas do subgrupo PIII-HCR, que não apresentam a HVR, incluindo a bothropasina, devem reconhecer os ligantes, através de outro mecanismo que não seja por esse "loop” do domínio C, podendo ser, como já comentado, através da cadeia lateral do resíduo glutâmico do motivo ECD do domínio desintegrina. 


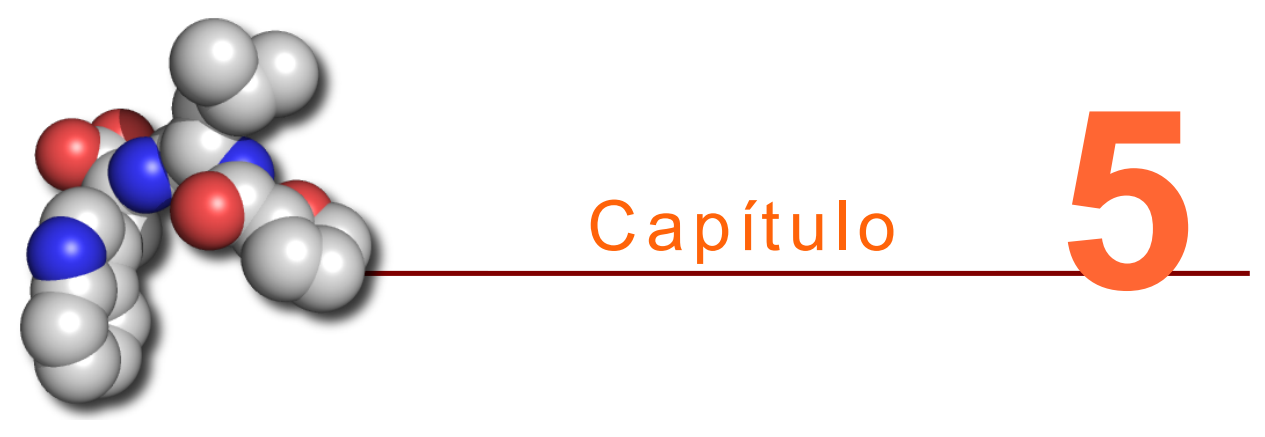

\section{CONCLUSÕES E PERSPECTIVAS}

O presente projeto de doutorado teve como objetivo o estudo estrutural de uma metaloproteinase/desintegrina, oriunda do veneno da serpente (SVMP) Bothrops jararaca.

Foram realizados estudos estruturais de amostras obtidas por dois procedimentos diferentes de purificação e verificado que as proteínas purificadas e cristalizadas, em ambos os processos, tratam-se da bothropasina. Esses resultados foram surpreendentes, pois, a princípio, acreditava-se que a amostra supostamente era de jararagina, uma proteína isoforma à bothropasina.

Tanto a bothropasina, quanto a jararagina são obtidas, segundo a literatura, através do isolamento do veneno bruto de $B$. jararaca utilizando colunas cromatográficas diferentes. No entanto, a cristalização mostra que, possivelmente, a fração de maior proporção no veneno seja de bothropasina. Além disso, haja vista que as duas proteínas apresentam massa molecular e ponto isoelétrico praticamente idênticos, a separação das duas isoformas torna-se extremamente difícil e o emprego de outras técnicas, como espectrometria de massas e/ou seqüenciamento protéico, fazem-se necessárias para o discernimento entre essas duas isoformas. 
Uma característica importante dessa proteína é a capacidade de sofrer autólise com produção dos domínios metaloprotease e o domínio desintegrina/rico em cisteína. Para diminuir a ocorrência desse processo e conseqüentemente melhorar o rendimento da obtenção de cristais de bothropasina, o inibidor sintético POL647 mostrou-se fundamental. Centenas de cristais de bothropasina também foram obtidos na ausência do inibidor, contudo, nenhum dos cristais testados apresentou um bom poder de difração, a ponto de ajudar no procedimento de obtenção da estrutura cristalográfica.

A condição ideal de cristalização foi bothropasina concentrada a 8 $\mathrm{mg} / \mathrm{mL}$ em acetato de amônia $40 \mathrm{mM}$, solução tamponante de acetato de sódio 100 mM, pH 4.6 e $29 \%$ de PEG 4000 como agente precipitante à temperatura de $4 \infty \mathrm{C}$. Os cristais obtidos foram submetidos a experimentos de difração de raios $\mathrm{X}$ no Laboratório Nacional de Luz Síncrotron em Campinas, no “Brookhaven National Synchrotron Light Source”, Upton, NY, EUA e no Instituto de Física de São Carlos USP, em um gerador ânodo rotatório de raios X. Todas as tentativas objetivaram a busca por melhores conjuntos de imagens de difração.

Devido a características intrínsecas da proteína e dos cristais de bothropasina, o melhor conjunto de dados obtido foi de, aproximadamente, $2,80 \AA \AA$ de resolução. Por não possuir estruturas homólogas para o domínio rico em cisteína, diversas tentativas de incorporação de metais pesados aos cristais protéicos foram executadas e os melhores resultados foram obtidos em ensaios de "quick-soaking" do cristal em 0,5 M de Iodeto de Sódio (NaI).

A partir de uma combinação de experimentos de substituição molecular e contribuição dos espalhadores anômalos (iodo), fases iniciais foram encontradas, permitindo, assim, a caracterização do domínio metaloprotease (o que representa, 
aproximadamente, metade da estrutura) através de um experimento de SAD/MR. A solução das fases possibilitou o emprego de métodos de reconhecimento de padrões em densidades eletrônicas, com o intuito de traçar, inicialmente, as posições dos átomos que compõem a cadeia principal dos domínios, ainda desconhecidos, da proteína. Todavia, a correta interpretação dos mapas de densidade eletrônica foi impossibilitada devido à presença do alto conteúdo de pontes dissulfeto nos domínios ricos desintegrina e rico em cisteína (6 pontes) e à baixa resolução dos mapas de densidade eletrônica.

Através de predição de estruturas secundárias, foi constatado que o domínio, ainda inédito, era predominantemente formado por estruturas aleatórias, também chamadas de "loops", além de hélices- $\alpha$ e também fitas $\beta$. Os "loops" e bifurcações dificultaram a interpretação adequada dessas regiões, sendo necessária a utilização de métodos mais eficazes de atribuição de átomos nessas densidades.

A molécula de bothropasina é formada por três diferentes domínios: (1) metaloprotease e (2) tipo-desintegrina, associados às atividades de inibição da agregação plaquetária e de adesão celular e (3) rico em cisteína, de função ainda não esclarecida.

Na literatura, um “loop” no domínio C, cuja seqüência de aminoácidos é altamente variável (HVR) em P-III SVMPs, tem sido descrito como possível região de reconhecimento e/ou de ligação. Uma análise realizada, neste trabalho, a partir da estrutura primária de 41 proteínas representantes da classe P-III das SVMPs mostrou que, a despeito de sua grande similaridade, as proteínas podem ser classificadas como subgrupo PIII-HCR, como sendo aquelas que não apresentam a HVR em um dos "loops" presentes no domínio rico em cisteína (C) e subgrupo PIII-HVR, caracterizado por aquelas proteínas que apresentam o "loop" com seqüências 
altamente variáveis (HVR).

Embora seja realmente factível que a região HVR tenha a função de reconhecer e ligar-se a ligantes, isso só seria possível nas proteínas do grupo II, uma vez que as proteínas do grupo I têm essa região muito conservada e, sendo assim, não garantiria especificidade ao reconhecimento de ligantes. Todavia, neste trabalho, é sugerido que outras regiões da molécula possam ter essa função, como, por exemplo, o motivo ECD do domínio tipo-desintegrina que apresenta o ácido glutâmico exposto ao solvente e livre para realizar diversos tipos de interações.

Nenhuma estrutura de SVMP era conhecida até meados de 2006, fato esse que acarretou na utilização de técnicas cristalográficas específicas para a determinação da estrutura completa da bothropasina. Até o momento outras duas SVMPs de veneno de Cotralus atrox tiveram suas estruturas elucidadas, mas a análise realizada nesses trabalhos levou à proposição de mecanismos que mostram-se restritos a um grupo de proteínas e não para o grupo no qual a bothropasina e a jararagina se classificam.

A obtenção da estrutura da bothropasina abriu novas perspectivas de estudo que podem esclarecer os papéis dos domínios tipo-desintegrina e rico em cisteína nas SVMPs. A cristalização da bothropasina complexada com ligantes como a integrina e a determinação da estrutura tridimensional desse complexo podem mostrar as regiões envolvidas na ligação e elucidar o envolvimento de cada um dos domínios nas atividades biológicas da proteína.

As SVMPs são as principais toxinas envolvidas em patogenicidades induzidas por veneno e, sendo assim, importantes alvos na produção de antivenenos ainda mais eficazes. Contudo, os alvos fisiológicos das SVMPs, assim como seu mecanismo molecular de reconhecimento dos mesmos, ainda é pouco conhecido. A 
estrutura da bothropasina, apresentada neste trabalho, revela uma dinâmica e uma arquitetura modular dos domínios MDC para esta classe de proteínas. Essa flexibilidade intrínseca pode ser importante para um ajuste fino no reconhecimento do substrato, proporcionando um alinhamento espacial dos sítios de adesão e catalítico. 


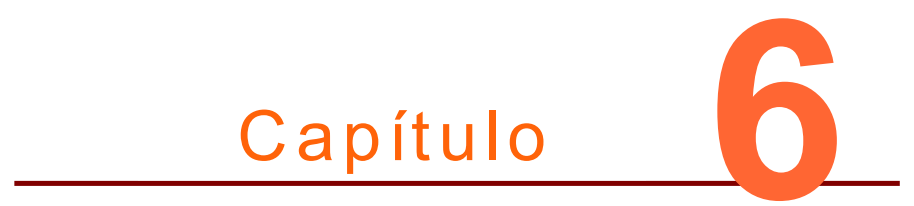

\section{CONSIDERAÇÕES FINAIS}

Desde o início do meu doutorado, tive ciência da importância e da dimensão do trabalho que me foi proposto pela minha orientadora Profa. Dra. Dulce Helena Ferreira de Souza, assim como pelos professores Glaucius Oliva e Richard Garratt.

Meu trabalho, que iniciou-se em abril de 2003, deu continuidade à busca pela elucidação da estrutura da bothropasina (na época "jararagina") que iniciou-se no fim de 1999, portanto, foram quase 8 anos para que esse trabalho fosse concretizado e, independente das adiversidades, fico muito contente com o desfecho desta história de muita luta e perseverança.

Durante meu doutoramento, também conquistei a oportunidade de participar do Programa de Doutoramento com Estágio no Exterior - PDEE, mantido pela CAPES, no Laboratório do Prof. Tom Blundell, Coordenador do Grupo de Cristalografia e Biocomputação no Departamento de Bioquímica da Universidade de Cambridge, Reino Unido. O Prof. Blundell é um renomado especialista em cristalografia de proteínas e modelagem molecular, tendo mais de 300 publicações em revistas de elevado impacto na literatura acadêmica. No Laboratório de 
Biocomputação, coordenado por ele, diversos programas foram desenvolvidos e testados em diferentes sistemas, demonstrando um excelente desempenho, mas ainda indisponíveis para uso público em geral.

Tive a oportunidade de aprender técnicas que poderiam ser empregadas na construção e refinamento de estruturas cristalográficas, principalmente em casos considerados difíceis de baixa resolução, assim como dar continuidade ao aprimoramento e aprendizado de técnicas para a construção de modelos tridimensionais por modelagem molecular comparativa. A modelagem molecular comparativa está presente em minha formação, desde meu mestrado, que foi desenvolvido nesta mesma instituição.

$\mathrm{Na}$ área de cristalografia de proteínas, tive a oportunidade de participar de congressos, debates e discussões com renomados cristalógrafos como o Prof. Randy Read (Professor do "Medical Research Council" (MRC), Universidade de Cambridge) e até então, sua aluna de pós-doc Dra. Airlie McCoy que, gentilmente, empregaram o programa Phaser (versão 2.0), que ainda estava em fase de testes e/ou aprimoramentos, na resolução da estrutura da bothropasina.

Participei, também, da construção de modelos tridimensionais de proteínas de diversos organismos, explorando análises comparativas de funcionalidade entre proteínas relacionadas com enovelamentos similares, porém, divergentes em relação às seqüências primárias, através da modelagem molecular por comparação durante minha participação na reunião bienal CASP 7 ("Critical Assessment of Techniques for Protein Structure Prediction" 7) como um dos integrantes do grupo do Prof. Blundell, representando a Universidade de Cambridge.

Além da relevância para o desenvolvimento desta tese de doutoramento, o estágio no exterior foi de grande importância para o aprendizado de novos 
conceitos, para a integração com um grupo estrangeiro de excelência e para o aperfeiçoamento profissional e formação acadêmica do doutorando. Ademais, esta experiência agregou conhecimentos que poderão auxiliar na resolução de problemas relacionados ao refinamento, resolução e modelagens de proteínas dentro do laboratório do CBME do IFSC onde o atual projeto de doutoramento se desenvolveu.

Maiores informações quanto ao que foi desenvolvido durante o estágio no exterior, são mostradas no Apêndice I.

Tive a oportunidade de participar, como colaborador, em trabalhos científicos diversificados. No Apêndice II, apresento esses trabalhos em seu texto original e na íntegra que foram contemplados com a publicação em revistas internacionais indexadas. Os trabalhos se resumem na obtenção de modelos estruturais, através do emprego da modelagem molecular comparativa e adequação dos modelos propostos a resultados experimentais.

Por fim, deixo claro que meus 6 anos de convivência com funcionários, alunos, professores, colegas e amigos no Instituto de Física de São Carlos, desde o meu mestrado, foram muito importantes para que atingisse maturidade científica, fundamental para meu aprendizado, além de criar laços de amizades duradouras e o mais importante de tudo: aprender a não desistir! 


\section{REFERÊNCIAS BIBLIOGRÁFICAS}

Adams, P.D., Gopal, K., Grosse-Kunstleve, R.W., Hung, L.W., Ioerger, T.R., McCoy, A.J., Moriarty, N.W., Pai, R.K., Read, R.J., Romo, T.D., Sacchettini, J.C., Sauter, N.K., Storoni, L.C. and Terwilliger, T.C. (2004) J. Synchrotron Rad. 11, 53-55.

Afonine, P.V., Grosse-Kunstleve, R.W. and Adams, P.D. (2005) CCP4 Newsletter July, Contribution $\mathbf{8}$.

Anai, K, Sugiki, M., Yoshida, E. and Maruyama, M. (1998) Toxicon, 36, 1127-1139.

Arnaout, M.A. (1990) Immunol. Rev., 114, 145-180.

Assakura M.T., Silva, C.A., Mentele, R., Camargo, A.C. and Serrano, S.M. (2003) Toxicon, 41, 217-227.

Atkinson, B.T., Jarvis, G.E. and Watson, S.P. (2003) J. Thromb. Hemost., 1, 1278-1287.

Barravieira, B., Lomonte, B., Tarkowski, A., Hanson, L.A. and Meira, D.A. (1995) J. Venom. Anim. Toxins, 1, 1-11.

Barros, S.F., Friedlanskaia, I., Petricevich, V.L. and KIpnis, T.L. (1998) Mediat. Inflam., 7, 339-346.

Bjarnason, J.B. and Fox, J.W. (1994) Pharmacol. Ther., 62, 325-372.

Blobel, C.P. (2005) Nat. Rev. Mol. Cell Biol., 6, 32-43.

Bode, W., Gomis-Ruth, F.X., Huber, R., Zwilling, R. and Stöcker (1992) Nature, 358, 164-167.

Bode, W., Gomis-Ruth, F.X. and Stocker, W. (1993) FEBS Lett., 331, 134-140.

Bradford, M.M. (1976) Analytical Biochemistry, 72, 248-254.

Brunger, A.T., Adams, P.D., Clore, G.M., DeLano, W.L., Gros, P., GrosseKunstleve, R.W., Jiang, J.S., Kuszewski, J., Nilges, M., Pannu, N.S., Read, R.J., Rice, L.M., Simonson, T. and Warren, G. (1998) Acta Cryst. D, 54, 905-921.

Cairns, R.A., Khokha, R. and Hill, R.P. (2003) Curr. Mol. Med., 3, 659-671.

Callard, R.E. and Gearing, A.J.H. (1994) The cytokine facts book. Academic Press, pp. 31

Calvete, J.J., Moreno-Marciano, M.P., Sauz, L., Jurgens, M., Schader, M., Raida, 
M., Benjamín, D.C. and Fox, J.W. (2000) Protein Sci., 9(7), 1365-1373.

Campbell, J.A. and Lamar, W. (1989) The Venomous Reptiles of Latin America. Cornell Univ. Press, Ithaca, USA.

Cardoso, J.L.C. (1997) Ofídios - Bothrops (jararaca, cruzeira). In: Nicolela, A., Barros, E., Torres, J.B. et al. eds. Acidentes com Animais Peçonhentos Consulta Rápida - Porto Alegre - Ministério da Saúde.

Cardoso, J.L.C., Fan, H.W., França, F.O.S., Jorge, M.T., Leite, R.P., Nishioka, S.A. et al. (1993) Quat. J. Med., 86, 315-325.

Chiang, H.S., Swaim, M.W. and Huang, T.F. (1994) Br. J. Haematol., 87, 325-331.

Clegg, D.O., Wingerd, K.L., Hikita, S.T. and Tolhurst, E.C. (2003) Front Biosci., 8, d723-d750.

Clissa, P.B., Laing, G.D., Theakston, R.G.D., Mota, I., Taylor, M.J. and Moura-daSilva, A.M. (2001) Toxicon, 39, 1567-1573.

Clissa, P.B., Lopes-Ferreira, M., Della-Casa, M.S., Farsky, S.H.P. and Moura-daSilva, A.M. (2006) Toxicon, 47, 591-596.

Collaborative Computational Project Number 4 (1994) Acta Cryst. D, 50, 760-763.

Cominetti, M.R., Terruggi, C.H.B., Ramos, O.H.P., Fox, J.W., Mariano-Oliveira, A., De Freitas, M.S., Figueiredo, C.C., Morandi, V. and Selistre-de-Araujo, H.S. (2004) Jol. Biol. Chem, 279, 18247-18255.

Coppolino, M.G. and Dedhar, S. (2000) Int. J. Biochem. Cell Biol., 32, 171-188.

Corpet, F. (1988) Nucleic Acids Res. 16, 10881-10890.

Correa Jr., M.C., Maria, D.A., Moura-da-Silva, A.M., Pizzocaro, K.F. and Ruiz, I. (2002) Toxicon, 40, 739-748.

Costa, E.P., Clissa, P.B., Teixeira, C.F.P. and Moura-da-Silva, A.M. (2002) Inflamation, 26, 13-17.

Darribere, T., Skalski, M., Cousin, H.L., Gaultier, A., Montmory, C. and Alfandari, D. (2000) Biol. Cell, 92, 5-25.

Dauter, Z., Dauter, M. and Rajashankar, K. R. (2000) Acta Cryst. Section D, 56, 232-237.

De Luca, M., Ward, C.M., Ohmori, K., Andrews, R.K. and Berndt, M.C. (1995) Biochem. Biophys. Res. Commun., 206, 570-576.

Dennis, M.S. et al. (1989) Proc. Natl. Acad. Sci. (USA), 87, 2471-2475. 
Domont, G.B., Perales, J. and Moussatche, H. (1991) Toxicon, 29, 1183-1194.

Dzamba, B., Bolton, M. and Desimone, D. (2001) Frontiers in Molecular Biology, Cell Adhesion, Oxford University Press. Chapter 4, pp. 100-154. Oxford, UK.

Eliceiri, B.P. (2001) Circ. Res., 89, 1104-1110.

Emsley, P. and Cowtan, K. (2004) Acta. Cryst. D, 60, 2126-2132.

Escalante, T., Núñez, J., Moura-da-Silva, A.M., Rucuvado, A., Theakston, R.G.D. and Gutiérrez, J.M. (2003) Toxicol. Appl. Pharmacol., 193, 17-28.

Evans, P.R. (1993) Proceedings of CCP4 Study Weekend on Data Collection \& Processing, January 9-10, Daresbury Laboratory, Daresbury, UK.

Felsenstein, J. (1989) Cladistics, 5, 164-166.

Fox, J.W. and Bjarnason, J.B. (1998) Enzymes from snake venom. Alasken, Inc., Colorado, pp. 599-632.

Fox, J.W., Shannon, J.D., Stefansson, B., Kamiguti, A.S., Theakston, R.G.D., Serrano, S.M.T., Camargo, A.C.M. and Sherman, N. (2002) Role of Discovery Science in Toxinology: Examples in Venom Proteomics. In: Menez, A. (Ed.). Wiley, New York, pp. 97-106.

Fox, J.W. and Serrano, S.M. (2005) Toxicon, 45(8), 969-985.

França, F.O.S. (1997) Tese (Doutorado) - Faculdade de Medicina da Universidade de São Paulo.

French, G.S. and Wilson, K.S. (1978) Acta Cryst. A, 34, 517-525.

Gallagher, P., Bao, Y., Serrano, S.M., Laing, G.D., Theakston, R.D., Gutierrez, J.M., Escalante, T., Zigrino, P., Moura-da-Silva, A.M., Nischt, R., Mauch, C., Moskaluk, C. and Fox, J.W. (2005) Arch.Biochem. Biophys., 441(1), 1-15.

Gichuhi, P.M., Ford, W.C. and Hall, L. (1997) Int. J. Androl., 20(3), 165-170.

Gomis-Ruth, F.X., Kress, L.F. and Bode, W. (1993a) EMBO, 1, 4151-4157.

Gomis-Ruth, F.X., Stöcker, W., Huber, R., Zwilling, R. and Bode, W. (1993b) J. Mol. Biol., 229(4), 945-968.

Gomis-Ruth, F.X., Meyer, E.F., Kress and L.F., Politi, V. (1998) Protein Sci., 7, 283-287.

Gong, W., Zhu, X., Liu, S., Teng, M. and Niu, L.J. (1998) Mol. Biol., 283, 657-668.

Gould, R.J., Polokoff, M.A., Friedman, P.A., Huang, T.F., Holt, J.C., Cook, J.J. et al. 
(1990) Proc. Soc. Exp. Biol. Med, 195, 168-171.

Grams, F., Huber, R., Kress, L.F., Moroder, L. and Bode, W. (1993) FEBS Lett., $335,76-80$.

Gutiérrez, J. and Rucavado, A. (2000) Biochimie, 82, 841-850.

Gutierrez, J.M., Chaves, F., Bolaños, R., Cerdas, L., Rojas, E., Arroyo, O. et al. (1981) Toxicon, 19, 493-500.

Hampel, A., Labananskas, M., Conners, P.G., Kirkegard, L., Raj Bhandary, U.L., Sigler, P.B. and Bock, R.M. (1968) Science, 162, 1384-1386.

Hanahan, D. and Weinberg, R.A. (2000) Cell, 100, 57-70.

Harrison, R.A., Richards, A., Laing, G.D. and Theakston, R.G.D. (2002) Vaccine, 15, 1702-1706.

Harrison, R.A., Moura-da-Silva, A.M., Laing, G.D., Wu, Y., Richards, A., Broadhead, A., Bianco, A.E. and Theakston, R.G.D. (2000) Clin. Exp. Immunol., 121, 358-363.

Hati, R., Mitra, P., Sarker, S. and Bhattacharyya, K.K. (1999) Crit. Rev. Toxicol., 29, $1-19$.

Hite, L.A., Jia, L.G., Bjarnason, J.B. and Fox, J.W. (1994) Arch. Biochem. Biophys., 308, 182-191.

Ho, P.L., Serrano, S.M.T., Chudzinski-Tavassi, A.M., Moura-da-Silva, A.M., Mentele, R., Caldas, C., Oliva, M.L.V., Batista, I.F.C. and Sarno de Oliveira, M.L. (2002) Biochem. Biophys. Res. Commun., 294, 879-885.

Hoge, A.R. and Romano-Hoge, S.A.R.W.L. (1981) Mem. Inst. Butantan, 42/43, 179-309.

Hooper, N.M. (1994) FEBS Lett., 354, 1-6.

Huang, T. F. (1998) Cell Mol. Life Sci., 54, 527-540.

Huang, T.F. and Niewiarowski, S. (1994) J. Toxicol, 13, 253-273.

Hynes, R.O. (1992) Cell, 110, 673-687.

Igarashi, T., Araki, S. and Takeda, S. (2007) FEBS Letter, 581(13), 2416-2422.

Jia, L.G., Shimokawa, K., Bjarnason, J.B. and Fox, J.W. (1996) Toxicon, 34, 1269-1276.

Jia, L.G., Wang, X.M., Shannon, J.D., Bjarnason, J.B. and Fox, J.W. (1997) Biol. 
Biochem., 272, 13094-13102.

Jia, L.G., Wang, X.M., Shannon, J.D., Bjarnason, J.B. and Fox, J.W. (2000) Arch. Biochem. Bioph., 373, 281-286.

Jin, H. and Varner, J. (2004) Br. J. Cancer, 90, 561-565.

Jurgilas, P.B., Neves-Ferreira, A.G., Domont, G.B. and Perales, J. (2003) Toxicon, 42, 621-628.

Kamiguti, A.S., Theakston, R.D.G., Desmond, H.P. and Hutton, R.A. (1991) Toxicon, 29, 1097-1105.

Kamiguti, A.S., Slupsky, J.R., Zuzel, M. and Hay, C.R.M. (1994a) Thromb. Haemost., 72, 244-249.

Kamiguti, A.S., Desmond, H.P., Theakston, R.D.G., Hay, C.R.M. and Zuzel, M. (1994b) Biochim. Biophys. Acta, 1200, 307-314.

Kamiguti, A.S., Hay, C.R., Theakston, R.D.G. and Zuzel, M. (1996a) Toxicon, 34, 627-642.

Kamiguti, A.S., Hay, C.R. and Zuzel, M. (1996b) Biochem. J., 320, 635-641.

Kamiguti, A.S., Moura-da-Silva, A.M., Laing, G.D., Knapp, T., Zuzel, M., Crampton, J.M. and Theakston, R.D.G. (1999) Arch. Biochem. Biophys., 369(2), 295-301.

Kamiguti, A.S., Theakston, R.D.G., Watson, S.P., Bon, C., Laing, G.D. and Zuzel, M. (2000) Arch. Biochem. Biophys., 374, 356-362.

Kamiguti, A.S., Gallagher, P., Marcinkiewicz, C., Theakston, R.D.G., Zuzel, M. and Fox, J.W. (2003) FEBS Letter, 549(1-3), 129-134.

Kim, M., Carman, C.V. and Springer, T.A. (2003) Science, 301, 1720-1725.

Kleywegt, G.J. and Jones, T.A. (1994) CCP4/ESF-EACBM Newsletter on Protein Crystallography, 31, 9-14.

Kondo, H., Kondo, S., Ikezawa, H. and Murata, R. (1960) Jpn. J. Med. Sci. Biol., 13, 43-51.

Krissinel, E. and Henrick, K. (2005) In: Berthold, M.R. et al. (Eds.): CompLife 2005, LNBI 3695, 163-174. Springer-Verlag, Berlin, Heidelberg.

Laemmli, U.K. (1970) Nature, 227, 680-685.

Laing, G.D., Clissa, P.B., Theakston, R.D.G., Moura-da-Silva, A.M. and Taylor, M.J. (2003) Eur. J. Immunol, 33, 3458-3463. 
Laing, G.D. and Moura-da-Silva, A.M. (2005) Toxicon, 45, 987-996.

Laskowski, R.A., McArthur, M.W., Moss, D.S. and Thornton, J.M. (1993) J. Apply. Cryst., 26, 283-291.

Leslie, A.G.W. (1992) Joint CCP4 + ESF-EAMCB Newsletter on Protein Crystallography, No 26.

Lindberg, F.P., Gresham, H.D., Reinhold, M.I. and Brown, E.J. (1996) J. Cell Biol., 134, 1313-1322.

Lo Conte, L., Chothia, C. and Janin, J. (1999) J. Mol. Biol., 285, 2177-2198.

Lomonte, B., Gutierrez, J.M., Borkow, G., Ovadia, M., Tarkowski, A. and Hanson, L.A. (1994) Toxicon, 32, 505-510.

Lopes-Ferreira, M., Moura-da-Silva, A.M. and Mota, I. (1992) Toxicon, 30, 1591-1602.

Manual de Diagnóstico e Tratamento de Acidentes por Animais Peçonhentos. (2003) Ministério da Saúde, Fundação Nacional de Saúde.

Mandelbaum, F.R., Reichel, A.P. and Assakura, M.T. (1982) Toxicon 45(8), 969-985.

Marcinkiewicz, C., Calvete, J.J., Vijay-Kumar, S., Marcinkiewicz, M.M., Raida, M., Schick, P. et al. (1999) Biochemistry, 38, 13302-13309.

Mariano-Oliveira, A., Coelho, A.L., Terruggi, C.H., Selistre-de-Araujo, H.S., BarjaFidalgo, C. and Freitas, M.S. (2003) Eur. J. Biochem., 270(24), 4799-4808.

Markland, F.S. (1998) Toxicon, 36, 1749-1800.

Masuda, S., Hayashi, H. and Araki, S. (1998) Eur. J. Biochem., 253, 36-41.

Matthews, B.W. (1968) J. Mol. Biol., 33, 491-497.

McCoy, A.J., Storoni, L.C. and Read, R.J. (2004) Acta Cryst. D., 60, 1220-1228.

McCoy, A.J., Grosse-Kunstleve, R.W., Storoni, L.C. and Read, R.J. (2005) Acta Cryst. D., 61, 458-464.

McLane, M.A., Marcinkiewicz, C., Vijay-Kumar, S., Wierzbicka-Patynowski, I. and Niewiarowski, S. (1998) Proc. Soc. Exp. Biol. Med., 219, 109-119.

Moreira, L., Borkow, G., Ovadia, M. and Guitiérrez, J.M. (1994) Toxicon, 32, 977-987.

Moura-da-Silva, A.M., Della-Casa, M.S., David, A.S, Assakura, M.T., Butera, D., 
Lebrun. I., Shannon, J.D., Serrano, S.M. and Fox, J.W. (2003) Arch. Biochem. Biophys., 409, 395-401.

Moura-da-Silva, A.M., Laing, G.D., Paine, M.J., Dennison, J.M.T., Politi, V., Crampton, J.M. and Theakston, R.D.G. (1996a) Eur. J. Immunol., 26, 2000-2005.

Moura-da-Silva, A.M., Theakston, R.D.G. and Crampton, J.M. (1996b) J. Mol. Biol., 43(3), 263-269.

Myles, D.G., Kimmel, L.H., Blobel, C.P., White, J.M. and Primakoff, P. (1994) Proc. Natl. Acad. Sci. (USA), 91, 4195-4198.

Nagem, R.A.P., Dauter, Z. and Polikarpov, I. (2001) Acta Crystallographica Section $D, \mathbf{5 7}, 996-1002$.

Nagem, R.A.P., Polikarpov, I. and Dauter, Z. (2003) Meth. Enzymol.- Macrom. Cryst., 374, 120-137.

Neves-Ferreira, A.G., Perales, J., Fox, J.W., Shannon, J.D., Makino, D.L., Garratt, R.C. and Domont, G.B. (2002) J. Biol.Chem., 277, 13129-13137.

Niewiarowski, S., Mclane, M.A., Kloczewiak, M. and Stewart, G.J. (1994) Semin. Hematol., 31, 289-300.

Ortiz-Stern, A. and Rosales, C. (2003) Immunol. Lett., 90, 137-143.

Otero, R.; Nunez, V.; Gutierrez, J.M.; Robles, A.; Estrada, R.; Osorio, R.G. et al. (1997) Braz. J. Med. Biol. Res., 30, 375-379.

Paine, M.J., Desmond, H.P., Theakston, R.D. and Crampton, J.M. (1992) J. Biol. Chem., 267, 22869-22876.

Parise, L.V., Lee, J. and Juliano, R.L. (2000) Semin. Cancer Biol., 10, 407-414.

Petricevich, V.L., Teixeira, C.F.T., Tambourgi, D.V. and Gutiérrez (2000) Toxicon, 38, 1253-1266.

Pinto, A.F., Terra, R.M., Guimaraes, J.A. and Fox, J.W. (2007) Arch. Biochem. Biophys., 457, 41-46.

Polikarpov, I., Perles, L.A., de Oliveira, R.T., Oliva, G., Castellano, E.E., Garratt, R.C. and Craievich, A. (1998) J. Synchro. Radiat., 5, 72-76.

Ramos, O.H., Terruggi, C.H., Ribeiro, J.U., Cominetti, M.R., Figueiredo, C.C., Berard, M., Crepin, M., Morandi, V. and Selistre-de-Araujo, H.S. (2007) Arch. Biochem. Biophys., 461(1), 1-6.

Rocha, S.L.G., Lomonte, B., Neves-Ferreira, A.G.C., Trugilho, M.R.O., Junqueira- 
de-Azevedo, I., de L, M., Ho, P.L., Domont, G.B., Gutierrez, J.M. and Perlaes, J. (2002) Eur. J. Biochem., 269, 6052-6062.

Rosenfeld, G. (1971) Venomous Animal and Their Venoms, II, 346-381.

Ross, R.S. (2004) Cardiovasc. Res., 63, 381-390.

Rucuvado, A., Escalante, T., Franceschi, A., Chaves, F., Leon, G., Cury, Y., Ovadia, M. and Gutierrez, J.M. (2000) Am. J. Trop. Med. Hyg., 63, 313-319.

Schattner, M., Fritzen, M., Ventura, J.S., Albuquerque Modesto, J.C., Pozner, R.G., Moura-da-Silva, A.M. and Chuszinski-Tavassi, A.M. (2005) Biol. Chem., 386(4), 369-374.

Serrano, S.M., Jia, L.G., Wang, D., Shannon, J.D. and Fox, J.W. (2005) Biochem. J., 391, 69-76.

Serrano, S.M., Kim, J., Wang, D., Draguley, B., Shannon, J.D., Mann, H.H., Veit, G., Wagenes, R., Koch, M. and Fox, J.W. (2006) J. Biol. Chem., 281(52), 39746-39756.

Shah, N.K., Rejto, P.A. and Verkhivker, G.M. (1997) Proteins, 28, 421-433.

Shah, Z.H., Hakkaart, A.J.G., Arku, B., Jong, L., Spek, H.V.D., Grivell, L.A. and Jacobs, H.T. (2000) FEBS Lett., 478, 267-270.

Sheu, J.R., Yen, M.H., Kan, Y.C., Hung, W.C., Chang, P.T. and Luk, H.N. (1997) Biochem. Biophys. Acta, 1336, 445-454.

Shimokawa, K., Shannon, J.D., Jia, L.G. and Fox, J.W. (1997) Arch. Biochim. Biophys., 343, 35-43.

Souza, D.H.F., Iemma, M.R.C., Ferreira, L.L., Faria, J.P., Oliva, M.L.V., Zingali, R.B., Niewiarowski and Selistre-de-araujo, H.S. (2000) Arch. Biochem. Biophys., 384, 341-350.

Sugiki, M., Maruyama, M., Yoshida, E., Mihara, H., Kamiguti, A.S. and Theakston, D.G. (1995) Toxicon, 33, 1605-1617.

Sugiki, M., Yoshida, E., Anai, K. and Maruyama, M. (1998) Toxicon, 36, 993-1000.

Takeda, S., Igarashi, T., Mori, H. and Araki, S. (2006) EMBO J., 11, 2388-2396

Tanjoni, I., Butera, D., Bento, L., Della-Casa, M.S., Marques-Porto, R., Takehara, H.A., Gutierrez, J.M., Fernandes, I. and Moura-da-Silva, A.M. (2003a) Toxicon, 42, 801-808.

Terwilliger, T.C. (2003) Methods Enzymol., 374, 22-37. 
Theakston, R.G.D. and Reid, H.A. (1983) Bull. WHO, 61(6), 949-956.

Trikha, M., de Clerck, Y.A. and Markland, F.S. (1994) Cancer Res., 54, 4993-4998.

Usami, Y., Fugimura, Y., Miura, S., Shima, H., Yoshida, E., Yoshika, A., Hirano, K., Suzuki, M. and Titani, K.A. (1994) Biochem. Res. Commun., 201, 331-339.

Valente, R.H., Dragulev, B., Perales, J., Fox, J.W. and Domont, G.B. (2001) Eur. J. Biochem., 268, 3042-3052.

Watson, S.P. and Gibbins, J.M. (1998) Immunol. Today, 19, 260-264.

Weiss, H.J., Turitto, V.T. and Baumgartner, H.R. (1986) Blood, 67, 322-330.

Wolfsberg, T., Primakoff, P., Myles, D. and White, J. (1995) J. Cell Biol., 131, 275-278.

Woods, A. and Couchman, J.R. (1998) Trends Cell Biol., 8, 189-192.

Xue, W., Mizukami, I., Todd, R.F. and Petty, H.R. (1997) Cancer Res., 57, 1682-1689.

Yamamoto, S., Higucchi, Y., Yoshiyama, K., Shimizu, E., Kataoka, M., Hijiya, N. and Matsuura, K. (1999) Immunol. Today, 20, 278-284.

Zhou, O., Smith, J.B. and Grossman, M.H. (1995) Biochem., 307, 411-417.

Zigrino, P., Kamiguti, A.S., Eble, J., Drescher, C., Nischt, R., Fox, J.W. and Mauch, C. (2002) J. Biol. Chem., 277, 40528-40535. 


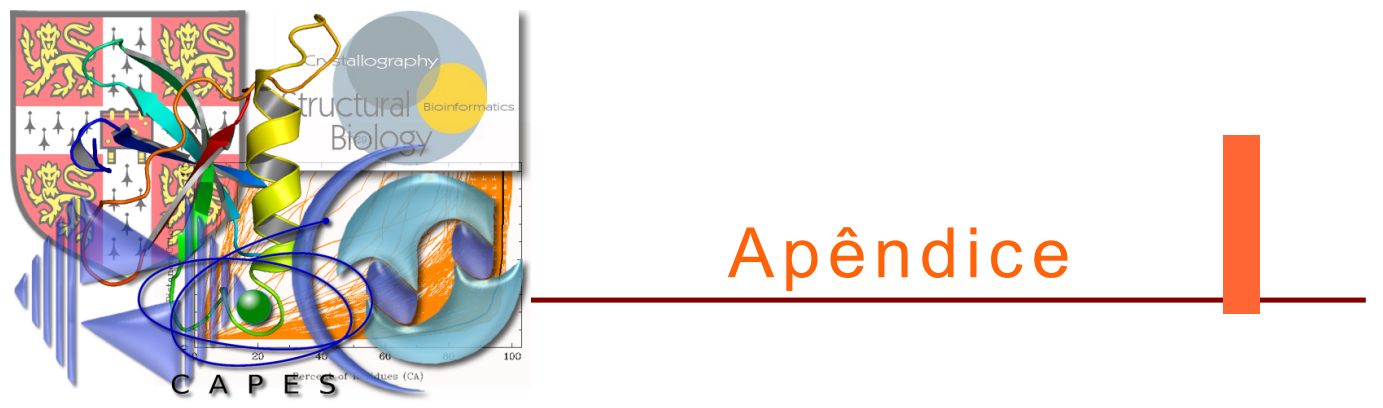

RELATÓRIO FINAL - PDEE 
RELATÓRIO FINAL DE ESTÁGIO DE DOUTORADO NO EXTERIOR PROGRAMA - PDEE - CAPES

JOÃO RENATO CARVALHO MUNIZ

NÚMERO DO PROCESSO: 3777-05-7

SÃO CALOS - SP 


\section{1 - Introdução e Objetivos Propostos}

A execução do Programa de Desenvolvimento de Estágio no Exterior (PDEE) pode ser dividido em duas etapas: Desenvolvimento dos estudos cristalográficos - relacionado com o estudo e determinação da estrutura tridimensional da Jararagina a partir de sua forma cristalina e estudos relacionados ao aprendizado e desenvolvimento de novas ferramentas relacionadas a modelagem molecular comparativa por homologia e/ou cálculos diretos (primeiros princípios, $a b$ initio) e serão discutidos nos itens 3.1 e 3.2 respectivamente.

Outro aspecto abordado no presente relatório, diz respeito à formação cultural e intelectual do doutorando durante o processo de aprendizagem como idioma, disponibilidade de infra-estrutura, adaptação cultural, etc, seguidos de uma avaliação pessoal sob forma de críticas e sugestões, como sugerido pelas normas do programa PDEE.

\section{1 - Desenvolvimento dos Estudos Cristalográficos}

O projeto de doutorado tem como objetivo o estudo estrutural da bothropasina, uma metaloprotease/desintegrina oriunda do veneno da serpente Bothrops jararaca. Esta proteína é uma toxina bastante estudada do ponto de vista bioquímico, devido a suas atividades de inibição da agregação plaquetária e de adesão celular (Kamiguti et al., 1996; Kamiguti et al., 1997; Moura-da-Silva et al., 2001). O estudo estrutural da bothropasina é de grande interesse devido a sua potencial aplicação no desenvolvimento de drogas anti-trombótica e anti-metastática. A molécula de bothropasina é formada por três diferentes domínios: os domínios "metaloprotease" e "desintegrina" estão associados às atividades de inibição da agregação plaquetária e de adesão celular enquanto que o domínio chamado "rico em cisteína" não possui uma função ainda esclarecida.

Nesta pesquisa, a proteína foi isolada do veneno bruto da B. Jararaca fornecido pelo Instituto Butantan, com a utilização de cromatografia de troca iônica em coluna DEAE-SefaroseFF, seguida de cromatografia por exclusão de tamanho em coluna Superdex75. A proteína apresenta um adequado nível de pureza e o rendimento do processo de purificação é de aproximadamente $2 \%$ da massa inicial do veneno.

Uma característica importante dessa proteína é a capacidade de sofrer 
autólise, com produção dos domínios metaloprotease e o domínio desintegrina/rico em cisteína. Para diminuir a ocorrência de autólise e conseqüentemente melhorar o rendimento do processo de obtenção da bothropasina, o inibidor sintético POL647 (Gomis-Ruth et al., 1998) foi utilizado. Testes de cristalização da bothropasina foram realizados primeiramente com as soluções dos Fatoriais 1 e 2 da Hampton. Algumas condições provenientes dessa matriz esparsa mostraram-se mais propícias a uma precipitação sob forma de cristais. Após a obtenção de pequenos cristais essas condições foram refinadas e a condição ideal final foi a de $60 \mathrm{mM}$ de acetato de amônio, $200 \mathrm{mM}$ de acetato de sódio em pH de 5,6 e 30\% de precipitante PEG 4000 com a proteína a aproximadamente $8 \mathrm{mg} / \mathrm{mL}$. Os cristais obtidos foram submetidos a experimentos de difração de raios X no Laboratório Nacional de Luz Síncrotron em Campinas, no "Brookhaven National Synchrotron Light Source", Upton, NY, EUA e no Instituto de Física de São Carlos - USP, em um gerador ânodo rotatório de raios X. Todas as tentativas objetivaram a busca por melhores conjuntos de imagens de difração.

Devido a características intrínsecas da proteína e dos cristais de Jararagina, o melhor conjunto de dados obtido foi a aproximadamente $2,75 \AA$ de resolução. Por não possuir estruturas homólogas para os domínios desintegrina e rico em cisteínas, diversas tentativas de incorporação de metais pesados aos cristais protéicos foram executadas e os melhores resultados foram obtidos em ensaios de soaking do cristal em 0,5 M de Iodeto de Sódio (NaI). A partir de uma combinação de experimentos de substituição molecular e contribuição dos espalhadores anômalos (Iodo) fases iniciais foram encontradas, permitindo assim a caracterização do domínio metaloprotease (o que representa aproximadamente metade da estrutura) através de um experimento de SAD. A solução das fases possibilitou o emprego de métodos de reconhecimento de padrões em densidades eletrônicas, com o intuito de traçar inicialmente as posições dos átomos que compõem a cadeia principal dos domínios ainda desconhecidos da proteína. Todavia, a interpretação dos mapas de densidade eletrônica tem sido impossibilitada devido a presença do alto conteúdo de pontes dissulfeto (14) nos domínios desintegrina e rico em cisteína e à baixa resolução dos mapas de densidade eletrônica. Através de predição de estruturas secundárias constatamos que os dois domínios ainda inéditos são predominantemente formados por estruturas aleatórias, também chamadas de "loops", laços e voltas. Os "loops" e bifurcações dificultam a interpretação adequada 
dessas regiões, sendo necessária a utilização de métodos mais eficazes de atribuição de átomos nessas densidades.

\section{2 - Modelagem Molecular Comparativa}

$\mathrm{O}$ avanço nos estudos de seqüenciamento de genomas de diversos organismos tem contribuído de maneira significativa para o desenvolvimento de novos métodos capazes de compilar grandes volumes de informações, seja diretamente através de estudos de genômica funcional, estrutural, ou comparativa, seja indiretamente a partir do proteoma, transcriptoma, ou metaboloma (Skolnick et al., 2000; Baker e Sali, 2001). Diversas pesquisas comprovaram que muitas proteínas das mais diferentes famílias compartilham sub-estruturas/motivos e enovelamentos semelhantes (Orengo et al., 1997; Yang e Honing, 2000; Martí-Renom, 2000; Harrison et al., 2002; Pazos e Sternberg, 2004).

A principal motivação desta segunda parte do trabalho consiste em solucionar alguns problemas comumente encontrados durante o processo de modelagem molecular por comparação/“threading” protéico e métodos ab initio, tais como identificação da(s) proteína(s) que será(ão) utilizada(s) como molde(s) (baseado em um alinhamento seqüencial/estrutural), modelagem das regiões alinhadas e não alinhadas (neste caso por métodos diretos), minimização energética de todo o modelo obtido e subseqüente validação do mesmo. Para a realização dessa tarefa, uma nova metodologia de modelagem molecular foi desenvolvida no Laboratório do Prof. Blundell: O pacote de programas Orchestrar ${ }^{5}$

\section{2 - Resultados Alcançados}

\section{1 - Elucidação da Estrutura Tri-dimensional da Bothropasina}

Diferentes abordagens foram realizadas no intuito de se obter a estrutura cristalográfica completa da bothropasina. Dentre as abordagens, a mais produtiva foi a utilização do programa Phaser (McCoy et al., 2004; 2005) somada às modificações das densidades eletrônicas e achatamento do solvente (CCP4, 1994; Cowtan, 1994), resultando em mapas de densidade eletrônica mais bem interpretáveis.

A versão do programa Phaser utilizada (versão 2.0) no presente trabalho ainda está em fase de testes e/ou aprimoramentos, mas foi gentilmente empregada

5 Resultados ainda não publicados 
na resolução do problema das fases pelo seu próprio criador, o Prof. Dr. Randy Read - Professor do Medical Research Council (MRC) da Universidade de Cambridge. Dentre as características desse programa, pode-se citar a capacidade de faseamento utilizando-se de informações de espalhadores anômalos como átomos pesados (provenientes de um experimento de SAD, MAD, SIRAS, etc por exemplo) além da possibilidade de faseamento por Substituição Molecular.

De posse de mapas melhores (mais interpretáveis) e de estruturas homólogas à bothropasina a construção de todos os três domínios tornou-se possível (figura AI.1). Dados comparativos do tipo "antes e depois" podem ser visualizados na figura AI.2.

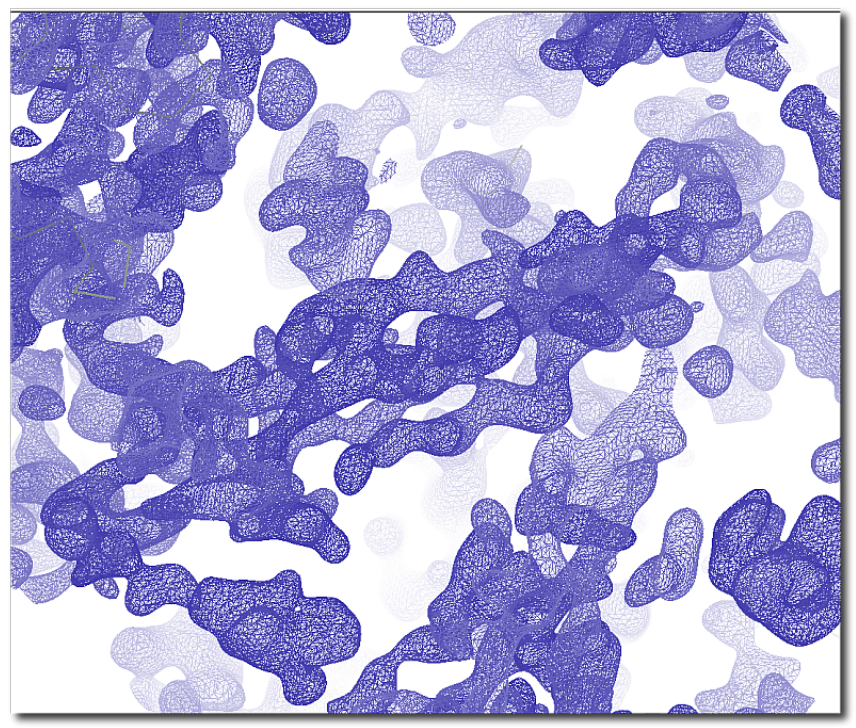

Figura AI.1: Mapa de densidade eletrônica das regiões dos domínios desintegrina e rico em cisteína. Com mapas mais bem interpretáveis foi possível traçar os átomos das cadeias principais e laterais para os dois domínios da bothropasina. 
(a)

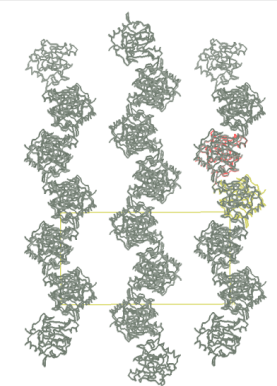

(a')

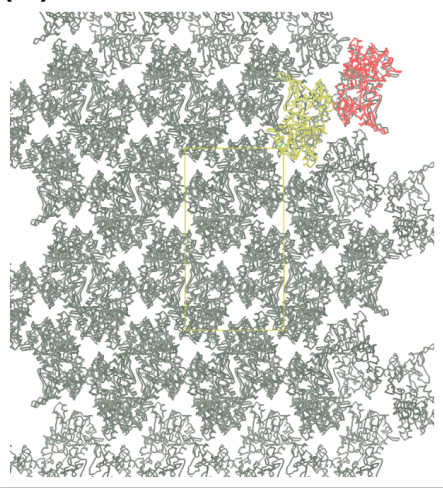

(b)

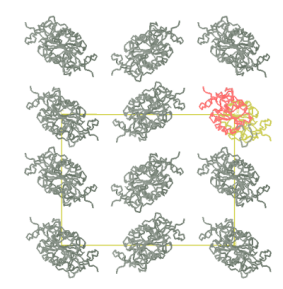

(b')

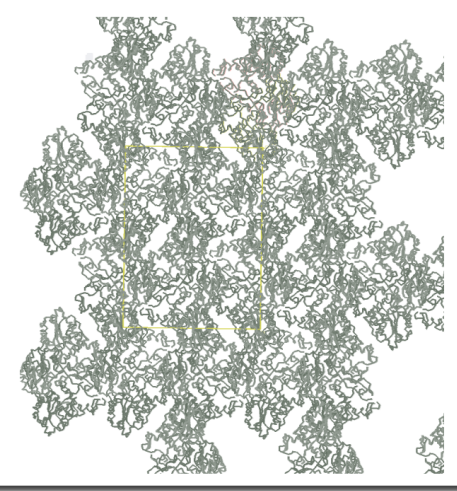

(c)

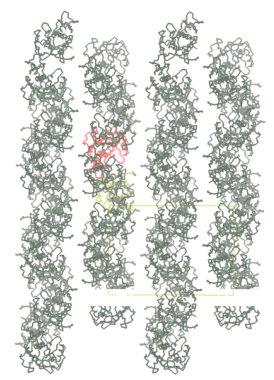

(c')

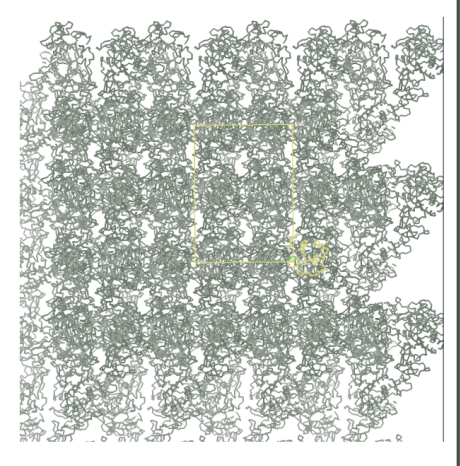

Figura AI.2: Empacotamento cristalino ao longo dos eixos a, b e c da célula unitária. Uma vez traçados todos os domínios da bothropasina, pode ser observado o contato cristalino entre as moléculas em seu respectivo empacotamento. As figuras (a), (b) e (c) mostram o empacotamento cristalino apenas para o domínio metaloprotease da bothropasina ao longo dos eixos a, b e c enquanto que as figuras (a'), (b') e (c') mostram o empacotamento cristalino para os três domínios da bothropasina e suas interações intermoleculares.

Uma vez traçada toda a cadeia principal, a etapa subseqüente foi o posicionamento correto das cadeias laterais, otimização da geometria dos resíduos e refinamento de toda a estrutura. Esses processos foram realizados com o emprego dos programas CNS (Brunger et al., 1998), Refmac5 e (Murshudov et al., 1997). A figura AI.3 ilustra uma representação da bothropasina em sua unidade assimétrica (duas moléculas) destacando seus três domínios através de diferentes representações. 

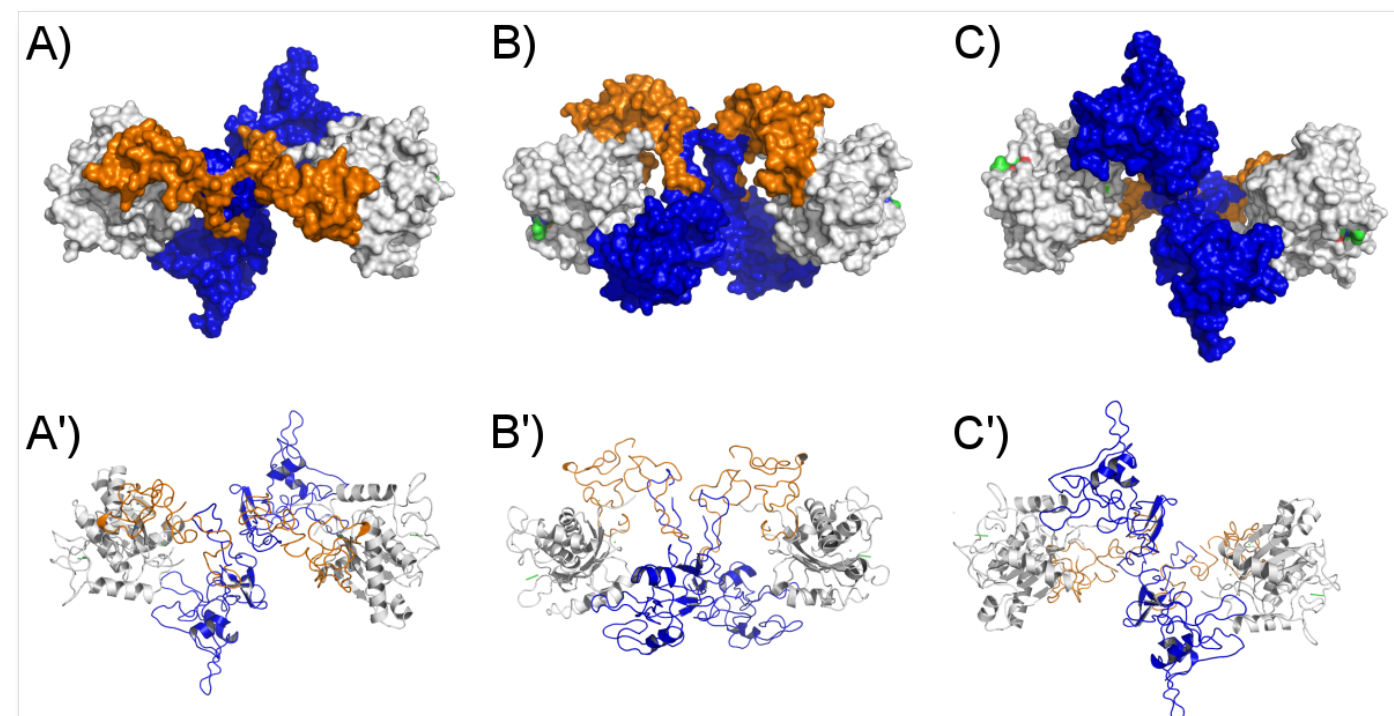

$\left.B^{\prime}\right)$

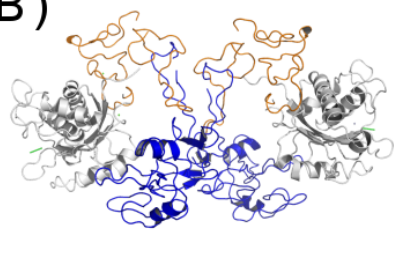

$\left.C^{\prime}\right)$

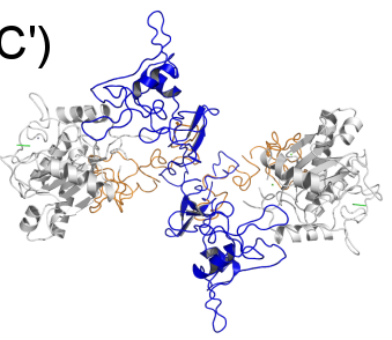

Figura AI.3: Diferentes representações para as duas moléculas da bothropasina na unidade assimétrica. A figura mostra a bothropasina em superfície e "cartoon" coloridas para os três domínios facilitando assim a identificação dos domínios metaloprotease, desintegrina e rico em cisteína (cinza, laranja e azul, respectivamente). A, B, C, A', B' e $\mathrm{C}^{\prime}$ correspondem a diferentes orientações: A e A', visão superior; B e B', visão lateral; C e C', visão inferior, respectivamente.

A atual etapa de desenvolvimento do projeto de doutorado caracteriza-se pelo refinamento da estrutura da bothropasina com a utilização dos programas CNS e Refmac5. Dados do refinamento da estrutura da bothropasina são mostrados na Tabela AI.I. A estrutura será depositada em banco de estrutura protéica e um artigo descrevendo a estrutura da bothropasina e sua relação com suas diversas atividades biológicas está sendo redigido.

Portanto, será possível o cumprimento de todos os planos propostos no projeto de doutoramento dentro do prazo inicialmente estabelecido de quatro anos. 
Tabela AI.I - Estatísticas da coleta de dados e refinamento. O conjunto coletado é proveniente de um "soaking" em NaI $0,5 \mathrm{M}$ por aproximadamente 2 minutos.

\begin{tabular}{lc}
\hline & Bothropasina - NaI \\
\hline Fonte de raios X & MX1, LNLS-Brasil \\
Comprimento de onda $(\lambda)$ & 1,4270 \\
Ângulo de oscilação $\left(^{\circ}\right)$ & 1,00 \\
Número de imagens & 344 \\
Grupo espacial & $\mathrm{P} 2{ }_{1} 2_{1} 2_{1}$ \\
Parâmetros da célula unitária & \\
a $(\AA)$ & 72,5 \\
b $(\AA)$ & 101,2 \\
c $(\AA)$ & 133,6 \\
Limites na resolução & $58,93-2,80(2,9-2,80)$ \\
Mosaicidade & 0,75 \\
Reflexões totais & 880327 \\
Reflexões únicas & 26293 \\
Redundância & $13,4(13,3)$ \\
Completeza (\%) & $99,9(100,0)$ \\
$<I / \delta(\mathrm{I})>$ & $25,0(5,1)$ \\
$\mathrm{R}_{\text {sym }}$ & $8,3(48,5)$ \\
$\mathrm{R}_{\text {factor }}$ & 0,293 \\
$\mathrm{R}_{\text {free }}$ & 0,376 \\
\hline
\end{tabular}

\section{2 - Modelagem Molecular Comparativa}

O processo de desenvolvimento e aprendizado da modelagem molecular comparativa foi cumprido de maneira mais que satisfatória. Além de poder contar com a colaboração direta dos pesquisadores e desenvolvedores das ferramentas de bioinformática, uma grande oportunidade me foi dada pelo próprio Prof. Blundell sob forma de convite a participar do sétimo encontro CASP ${ }^{6}$ "Critical Assessment of Techniques for Protein Structure Prediction" 7 - 2006 "http://predictioncenter.org/casp7/Casp7.html") como um dos integrantes de seu grupo representando a Universidade de Cambridge.

A CASP tem como principais objetivos estabelecer as capacidades e limitações dos atuais métodos de modelagem de estrutura protéica a partir de sua seqüência de aminoácidos, visando determinar os progressos que vêm sendo feitos na área, assim como localizar os maiores "gargalos" nas predições estruturais (Moult et al., 2003). Os projetos na CASP são divididos basicamente em três categorias: (1)

6 A CASP é uma reunião mundial bienal entre pesquisadores especializados na área de bioinformática.

7 Acesso em 08/11/2006 
modelagem molecular comparativa; (2) reconhecimento de enovelamentos (padrões estruturais, domínios, motivos, etc.) e (3) métodos de obtenção de novos enovelamentos. Para isso, os mais diversos bancos de dados são selecionados e divididos em grupos com diferentes tipos de estruturas.

Um total de 23 proteínas (Figura AI.4) foram preditas pelo grupo utilizando-se diferentes abordagens como, principalmente, os programas MODELLER, RAPPER, CHORAL, CODA e FUGUE - todos desenvolvidos (com exceção do MODELLER, que tem o Prof. Blundell como um dos autores na primeira versão programa) no próprio Departamento de Bioquímica - Grupo de Cristalografia, Biologia Estrutural e Bioinformática da Universidade de Cambridge.

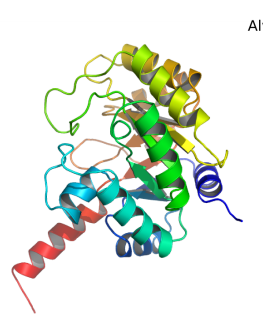

Alvo T0284_D1
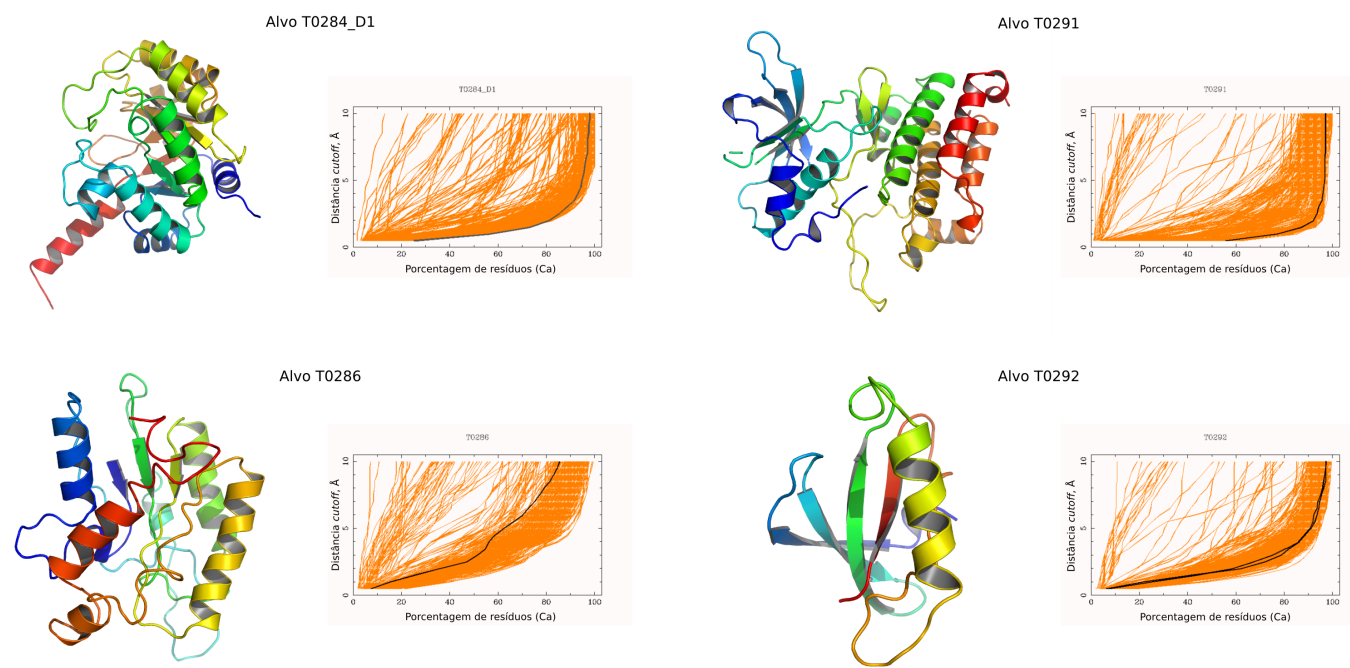

Alvo T0286
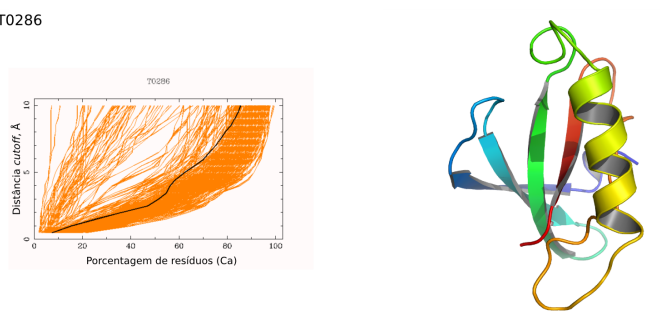

Alvo T0292

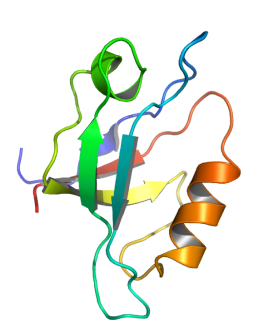

Alvo T0288_D1
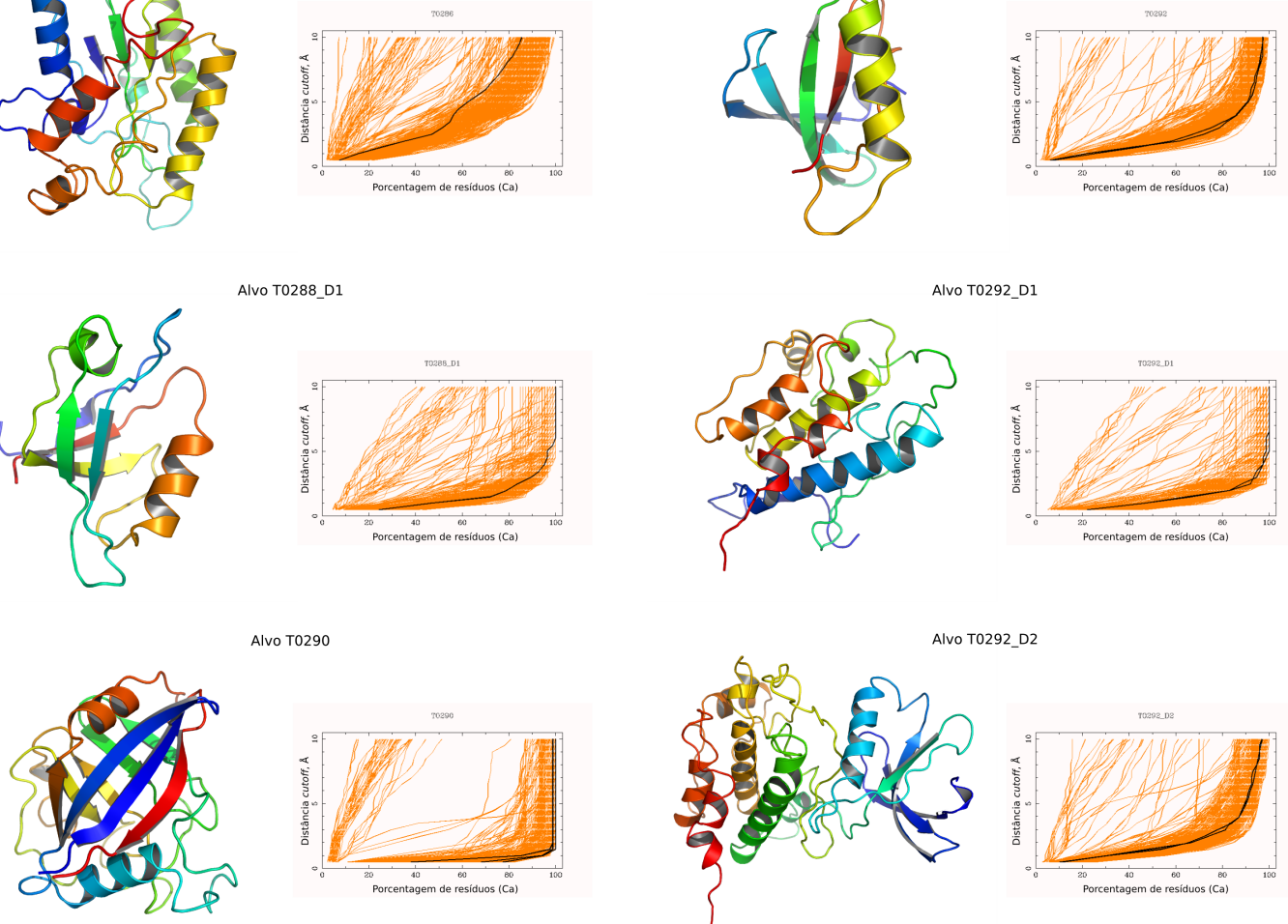

Alvo T0290
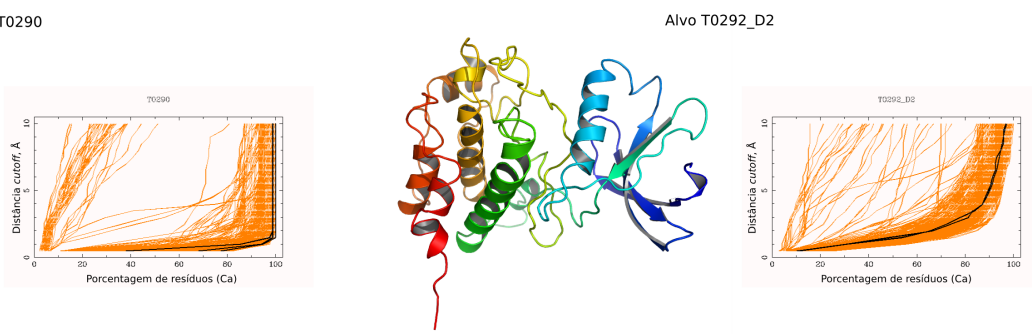

Figura AI.4 - continuação e legenda na próxima página. 
Figura AI.4 - continuação
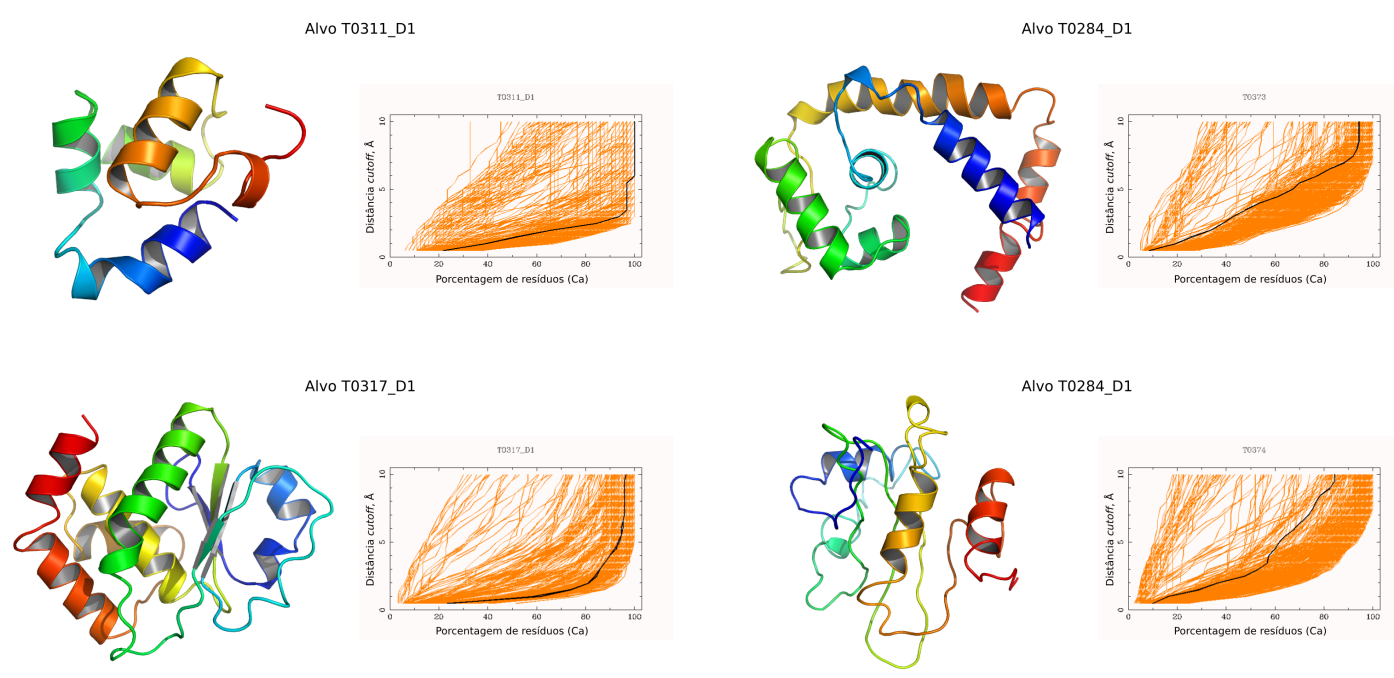

Alvo T0322_D1
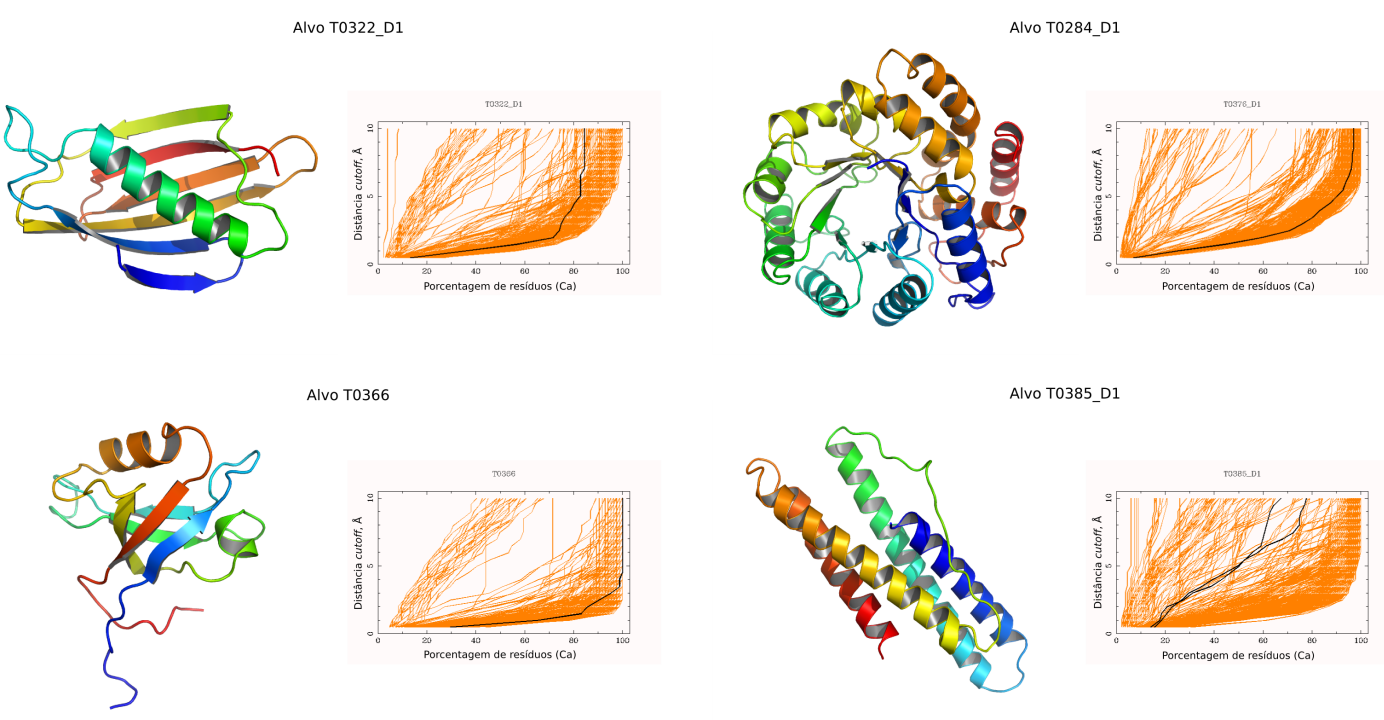

Alvo T0366

Figura AI.4: Resultados obtidos pelo grupo na sétima reunião da CASP. O código de uma letra e quatro dígitos numéricos, refere-se ao nome dado ao alvo a ser modelado. À esquerda, uma representação sob forma de "cartoon" do modelo predito a partir da estrutura primária da proteína e a direita, uma comparação entre o modelo predito pelo grupo (linha destacada na cor cinza escura), em relação a todos os modelos submetidos à CASP (linhas alaranjadas). No eixo das abscissas temos a porcentagem do número de carbonos alfa (CA) corretamente alinhados em relação a estrutura original e nas ordenadas, o desvio entre o modelo final e a estrutura cristalográfica em $\AA$.

Como observado na Figura AI.4, a grande maioria dos modelos preditos foi muito próxima às estruturas cristalográficas, como por exemplo os modelos T0284, T0288, T0290, T091, T092, T0311, T0366 e T0376 que obtiveram, quando 
comparadas as estruturas, um desvio máximo de $10 \AA$ e mais de $95 \%$ de resíduos alinhados.

No entanto, alguns modelos ficaram aquém da expectativa, como foi o caso do T0373, T0374 e T0377 com altos desvios em cerca de 60\% a 80\% de resíduos que representariam parte da estrutura cristalográfica. Nesses casos, a baixa identidade seqüencial (em certos casos menores que 5\% de identidade), foi o fator determinante no insucesso das predições, um dos motivos que justificam a necessidade de reuniões como essas.

\section{3 - Relevância na Formação Intelecto-Cultural}

Indubitavelmente, a possibilidade que me foi dada pela CAPES sob forma de auxílio do tipo bolsa de estudos para desenvolvimento de estágio no exterior, contribuiu de maneira veemente em minha formação intelecto-cultural por vários motivos. O contato direto com a língua inglesa foi muito importante para o aperfeiçoamento e aprendizagem da fala, escuta, leitura e escrita do idioma. De certa maneira, dada a exposição à língua, você se sente obrigado a se esforçar de maneira saudável para entender e compreender o idioma anglo-saxônico falado ao seu redor, seja através de contatos com outras pessoas, seja através da mídia como TV, cinema, rádio, jornais, internet e revistas. Todos esses fatores contribuem de maneira importante no processo de aperfeiçoamento e treinamento do idioma.

Minha adaptação foi bastante tranqüila, calma e naturalmente. Não encontrei grandes dificuldades em me adaptar à língua e começar a me comunicar de maneira fluente com as pessoas do grupo onde trabalhei, com companheiros de alojamento e colegas que tive.

Uma vez melhor adaptado, passei a desfrutar melhor da infra-estrutura ao meu redor. O laboratório tinha todas as condições necessárias para o desenvolvimento do meu trabalho, como mesa, computador de uso exclusivo, acesso a rede de periódicos, livros, revistas, etc... além de contar com o total apoio intelectual do meu co-orientador estrangeiro, Prof. Dr. Tom Blundell, do Prof. Dr. Randy Read, Dr. Dima Chirgadze, Dr. Rinaldo Montalvão, Dr. Nicholas Furnham, Dra. Eva Maria Priego, Tammy Cheng, dentre tantos outros que de maneira direta ou indireta me ajudaram nas discussões, implementações e apoio ao meu projeto me deixando ainda mais a vontade para desenvolvê-lo. 


\section{4 - Agradecimentos}

Gostaria de agradecer mais uma vez ao apoio da minha orientadora Profa. Dra. Dulce Helena Ferreira de Souza por toda orientação, apoio e incentivo, ao Prof. Dr. Glaucius Oliva e Prof. Dr. Richard Charles Garratt por todos os contatos, apoios e incentivos, assim como Cristiane Gomes Lazarini Estella e Wladerez Aparecida Gounella Caiado do Serviço de Pós-Graduação do Instituto de Física de São Carlos, por toda a atenção, coleguismo, apoio, incentivo e principalmente a CAPES por todo o suporte que me foi dado para a realização desse Programa de Desenvolvimento de Estágio no Exterior. Muito obrigado.

\section{5 - Referências Bibliográficas}

Baker, D. and Sali, A. (2001) Science, 294, 93-96.

Brunger, A.T., Adams, P.D., Clore, G.M., Delano, W.L., Gros, P., Grosse-Kunstleve, R.W., Jiang, J.-S., Kuszewski, J., Nilges, M., Pannu, N.S., Read, R.J., Rice, L.M., Simonson, T. and Warren, G.L. (1998) Acta Cryst., D54, 905-921.

CCP4 (1994), Acta Cryst., D50, 760-763.

Cowtan, K. (1994) ESF-EACBM Newsletter on Protein Crystallography, 31, p34-38.

Furnham, N., Doré, A., Chirgadze, D., de Bakker, P., DePristo, M. and Blundell, T. (2006) Structure, 14(8), 1313-1320.

Gomis-Ruth, F.X., Meyer, E.F., Kress, L.F. and Politi, V. (1998) Protein Sci., 7, 283-292.

Harrison, A., Pearl, F., Mott, R., Thornton, J. and Orengo, C. (2002) J. Mol. Biol., 323, 909-926.

Kamiguti, A.S., Hay, C.R.M. and Zuzel, M. (1996) Biochem J., 320, 635-641.

Kamiguti, A.S., Moura-da-Silva, A.M., Laing, G.D., Knapp, T., Zuzel, M., Crampton, J.M. and Theakston, R.D.G. (1997) Biochim. Biophys. Acta, 1335, 209-217.

Marti-Renom, M.A., Stuart, A.C., Fiser, A., Sanchez, R., Melo, F. and Sali, A. (2000) Annu. Rev. Biophys. Biomol. Struct., 29, 291-325.

McCoy, A.J., Grosse-Kunstleve, R.W., Storoni, L.C. and Read, R.J. (2005) Acta Cryst., D61, 458-464.

McCoy, A.J., Storoni, L.C. and Read, R.J. (2004) Acta Cryst., D60, 1220-1228.

Moura-da-Silva, A.M., Marcinkiewicz, C., Marcinkiewicz, M., Niewiarowski, S. (2001) Thrombosis Research, 2, 153-159.

Murshudov, G.N., Vagin, A.A. and E.J.Dodson (1997), Acta Cryst., D53, 240-255.

Orengo, C.A., Michie, A.D., Jones, S., Jones, D.T., Swindells, M.B. and Thornton, J.M. (1997) Structure, 5, 1093-1108.

Pazos, F. and Sternberg, M.J.E. (2004) Proc. Natl. Acad. Sci., 101, 14754-14759.

Skolnick, J., Fetrow, J.S. and Kolinski, A. (2000) Nature, 18, 283-287.

Takeda, S., Igarashi, T., Mori, H. and Araki, S. (2006) Embo J., 25, 2388-2396.

Yang, A.S. and Honig, B. (2000) J. Mol. Biol., 301, 665-678. 


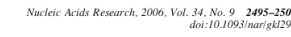

vo elF4A helicases in Trypanosoma brucei

nctionally distinct

Ilia, Nina A Tra nristian R. S. Reis, Rodolfo Katz, Joāo R. C. Muniz ${ }^{2}$

ndar', Mi avilable

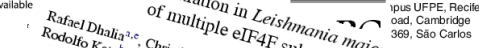

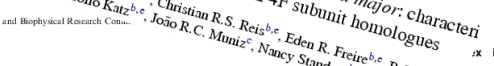

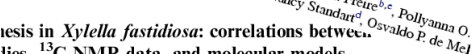

lies, ${ }^{13} \mathrm{C}$ NMR data, and molecular models

Apêndice

João Renato C. Munizic Helvécio Della Coleta Filho

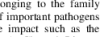

a Alves de Sousa ${ }^{-e}$, Marcos Antonio Machado

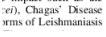

ARTIGOS PUBLICADOS EM REVISTAS INDEXADAS 


\title{
Fatty acid synthesis in Xylella fastidiosa: correlations between genome studies, ${ }^{13} \mathrm{C}$ NMR data, and molecular models
}

\author{
Denise Osiro ${ }^{\mathrm{a}, \mathrm{b}}$, João Renato C. Muniz ${ }^{\mathrm{c}}$, Helvécio Della Coleta Filho ${ }^{\mathrm{d}}$, \\ Alessandra Alves de Sousa d,e Marcos Antonio Machado ${ }^{\mathrm{d}}$, \\ Richard C. Garratt ${ }^{\mathrm{c}}$, Luiz Alberto Colnago $0^{\mathrm{a}, *}$ \\ a Embrapa Instrumentaãão Agropecuária, Rua XV de Novembro 1452, CEP 13560-970 São Carlos, SP, Brazil \\ ${ }^{\mathrm{b}}$ Instituto de Química de São Carlas, Universidade de São Paulo, CEP 13560-970 São Carlos, SP, Brazil \\ c Instituto de Física de São Carlos, Universidade de São Paulo, CEP 13560-970 São Carlos, SP, Brazil \\ ¿ Centro APTA Citras 'Sylrio Moreira'/Instituto Agronómico - CP 04, 13490-970 Cordeirópolis SP, Brazil \\ 'Enbrapa Recursas Genéticos e Biotecnologia, Parque Estação Biológica W5 Norte Final, 70770-900 Brasilia, DF, Brazil \\ Received 19 August 2004 \\ Available online 11 September 2004
}

\section{Abstract}

Xylella fastidiosa was the first plant pathogen to have its complete genome sequence elucidated. Routine database analyses suggested that two enzymes essential for fatty acid synthesis were missing, one of these is the holo-acyl-carrier-protein synthase. However, here we demonstrate, using ${ }^{13} \mathrm{C}$ NMR spectroscopy, that $X$. fastidios $a$ is indeed able to synthesize fatty acids from acetate via an apparently conventional metabolic pathway. We further identify a gene product HetI, an alternative phosphopantetheinyl transferase, which we propose to fill the missing link. Homology modeling of HetI shows conservation of the Coenzyme A binding site suggesting it to be an active enzyme and reveals several interesting structural features when compared with the surfactin synthaseactivating enzyme, on which the model was built. These include a simplified topology due to $\mathrm{N}$ - and $\mathrm{C}$-terminal deletions and the observation of a novel serine ladder.

(C) 2004 Elsevier Inc. All rights reserved.

Keywards: Xylella fastidiasa; NMR; Fatty acid biosyn thesis; Molecular modeling: Holo-acyl-carrier-protein synthase; HetI

Xylella fastidiosa is a gram-negative, xylem-limited bacterium, pathogenic to several plant species, and is the causal agent of citrus variegated chlorosis (CVC) in several sweet orange varieties in Brazil, as well as Pierce's disease in grapevines in the United States [1,2]. As a consequence of its significant impact on commercial agriculture it was the first plant pathogen to have its complete genome sequence published [1].

Almost all of our current knowledge concerning the composition and metabolic pathways of $X$. fastidiosa is derived from the comparison of its open reading frames

\footnotetext{
Corresponding author. Fax: +551633725958.

E-mail address: colnago@enpdia.embrapa.br (L.A. Colnago).
}

with the sequences deposited in public databases. These comparisons have allowed the assignment of $47 \%$ of the ORFs to a putative biological function [1]. However, several genes related to important metabolic pathways were not identified by routine database searching algorithms for one of a number of possible reasons. Either they (a) are genuinely lacking the genome, (b) are too distantly related to homologs within the database to be readily detectable on the basis of sequence alone or (c) have been replaced by a non-homologous counterpart.

One of the metabolic gaps reported in the original study is related to the ability of the bacterium to synthesize fatty acids. On the one hand, the genome analysis 
showed the presence of most of the enzymes necessary for synthesizing and elongating fatty acids from acetate. On the other hand, two Escherichia coli enzymes, holoacyl-carrier-protein synthase (ACPs), which converts inactive apoACP to its active holo form, and EnoylACP-reductase, which reduces the double bonds, were not identified in the $X$. fastidiosa genome [1]. This is a surprising observation given that fatty acids are ubiquitous in living organisms, playing essential roles in the makeup of biological membranes, for example, a vital component of every cell [3]. Certainly an intact biosynthetic pathway for fatty acids would be anticipated in $X$. fastidiosa.

Functional genomic studies of $X$. fastidiosa strains have thus far focused mainly on the transcriptome $[4,5]$ and proteome [6-8] but there has been little work so far reporting studies of the set of synthetic metabolites which constitute the bacterium's metabolome [9]. This is the focus of the current report which concerns the use of nuclear magnetic resonance (NMR) spectroscopy to identify the presence of fatty acids in $X$. fastidios $a$ and to demonstrate their in vivo synthesis. NMR spectroscopy is a recognized technique used in the determination of the chemical structure and composition of purified and raw biological materials in both solution and the solid state [10-13] as well as for following metabolic pathways in vivo $[10,14]$. Here, its application to the demonstration of an intact metabolic pathway for the synthesis of fatty acids in $X$. fastidiosa begs the question of how the apparent gaps identified in the original genome study are effectively overcome. An answer is given for the case of the ACP synthase, where the identification and homology modeling of an alternative 4'-phosphopantetheinyl transferase is suggested to assume this role.

The information generated by such metabolomic approaches will provide a complementary dataset, which, together with genomic data, should help in the elucidation of the mechanism of fatty acid biosynthesis in $X$. fastidiosa as well as in the identification of missing links in other apparently incomplete metabolic pathways.

\section{Materials and methods}

Nuclear magnetic resonance. Cells of $X$. fastidiosa $9 \mathrm{ase}$ strain were grown in PW broth [15], The cultures were agitated at $128 \mathrm{rpmat} 28^{\circ} \mathrm{C}$ for 8 days and centrifuged at $4000 \mathrm{~g}$ for $20 \mathrm{~min}$. The pellet was suspended and centrifuged twice. The final pellet was lyophilized for use in solid state NMR analysis. The dried sample was also used for the extraction with chloroform to evaluate the presence of free fatty acid [12].

For the acetate incorporation experiment, the pellet obtained in the first centrifugation was agitated in $200 \mathrm{~mL}$ of minimal mineral media [16], using $100 \mathrm{mg}$ of sodium acetate $99 \%\left[1-^{13} \mathrm{C}\right]$ from Cambridge Isotopes laboratory, as a carbon source, for four days. The culture was then centrifuged and re-suspended in $0.5 \mathrm{~mL}$ of deuterated water.

The ${ }^{13} \mathrm{C}$ NMR experiments were performed on a Varian Inova 400 (9.4 T) spectrometer. The solid state spectrum was acquired using a single pulse sequence with magic angle sample spinning $[12,13]$. The sample (about $200 \mathrm{mg}$ ) was packed into a $5 \mathrm{~mm}$ zirconium rotor and spun at the magic angle at a frequency of $9 \mathrm{kHz}$. The spectra were aver aged 10,000 times with a flip angle of $\pi / 2(\mathrm{pw}=7.2 \mu \mathrm{s})$, acquisition time, $a_{4}=100 \mathrm{~ms}$; spectral width, $s_{\mathrm{w}}=40 \mathrm{kHz}$; and recycle time, $r_{\mathrm{t}}=3 \mathrm{~s}$. The ${ }^{13} \mathrm{C}$ NMR spectrum in suspension in deuterated water was acquired using a $5 \mathrm{~mm}$ solution probe, pw $=19 \mu \mathrm{s}(\pi / 2), a_{\mathrm{t}}=1 \mathrm{~s}$, $s_{\mathrm{w}}=40 \mathrm{kHz}$, and $r_{\mathrm{t}}=3 \mathrm{~s}$.

Database searches. The recent description of a second 4'-phosphopantetheinyl transferase gene in E coli, coding for a product named YhhU, which is capable of suppressing an ACPs conditional lethal phenotype of the bacterium, suggested the presence of an alternative pathway for the generation of holoACP from apoACP in E coli [17]. This observation together with the absence of a homolog to the ACPs itself in X. fastidiasa stimulated a specific re-examination of the genome for a possible YhhU like molecule. Database searches of the $X$. fastidiosa genome [18] (http://aeg.lbi.ic.unicamp.br/xf) using the YhhU sequence as probe were performed with the BLASTp program [19] employing default parameters.

Subsequent searches of GenBank [20] (http://www.ncbi.nlm.nih. gov) were similarly performed with BLASTp using the $X$. fastidiosa Hetl sequence (XF1934) for the identification of 4'-phosphopantetheinyl transferase homologs. Fold recognition searches were made using GenThreader [21] and PSI-BLAST [22] using default parameters against the Protein Database [23] in order to improve the alignments to be used for subsequent homology modeling. The final alignment was manually adjusted after visual inspection of the structural homolog Sfp (surfactin synthetase-activating enzyme), a $4^{\prime}$-phosphopantetheinyl transferase of known structure from Bacillus subtitis [24].

Molecular madeling. Molecular models for HetI were built using restraint based homology modeling as implemented in the program MODELLER 6a [25]. The final alignment of the $X$. fastidiasa HetI protein against the Sfp sequence as described above was initially used as input to the MODELLER program together with the atomic coordinates of the latter (PDB file 1QR0). The low sequence identity between HetI and Sfp inevitably led to alignment ambiguities requiring the construction of several alternative models based on slightly different alignments (over 400 in total). This process included the deliberate misalignment of residues adjacent to deletions in order to facilitate gap closure.

Models were generated by coordinate copying for all atoms in common between the two sequences and completed using internal

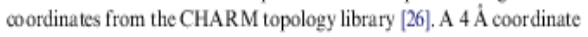
randomization was applied to each structure prior to optimization using up to 300 cycles of the variable target function method employing conjugate gradients. Refinement was subsequently performed in Cartesian space using the standard full molecular dynamics algorithm with simulated annealing as implemented in MODELLER 6a. Default limits were applied to the distance restraints and the Cocnzyme A molecule of the Sfp structure was included in the model calculation.

Besides the MODELLER pseudo-energy term, the quality of the models generated was also independently evaluated by the programs PROCHECK [27], VERIFY 3D [28], and the QUALTY option [29] of WHATIF [30] and used to select a representative model for structure analysis.

\section{Results}

Nuclear magnetic resonance

Xylella fastidiosa, as its name suggests, is a very slow growing bacterium [31] and the ${ }^{13} \mathrm{C}$ NMR procedures normally used for the analysis of fast growing bacteria such as E. coli [14] are not efficient. To verify the pres- 
ence of fatty acids as part of the makeup of the bacterium we analyzed a dried sample of $X$. fastidiosa with ${ }^{13} \mathrm{C}$ NMR spectroscopy using a single pulse sequence combined with magic angle sample spinning (Fig. 1A). This technique has been used to enhance spectral resolution and for the detection of mobile molecules, like fatty acid derivatives $[12,13]$. The $X$. fastidiosa spectrum is typical of a mono-unsaturated fatty acid chain, having strong signals at $\delta 14$, assigned to the terminal methyl group, $\delta 23-\delta 32$ due to the methylene groups, and weak peaks at $\delta 130$ and $\delta 173$ assigned to olefinic and carboxyl carbons, respectively $[10,12,13]$. The signal often seen at $\delta 34$ and assigned to $C_{2}$ is absent in the spectrum from $X$. fastidiosa. This signal is not observed in experiments using low power decoupling [12] as used here. The strong dipolar interaction with bonded hydrogens has not been eliminated, leading to broadening of the signal. The peak due to the carboxyl carbon $\left(\mathrm{C}_{1}\right)$ is, however, observed, albeit broadened, as a consequence of its weaker dipolar interaction. The signals expected at 862 and 870 relative to the glycerol moiety of triglycerides and phospholipids were not observed in the present spectrum.

To confirm the ability of $X$. fastidiosa to synthesize fatty acids from acetate we analyzed a $X$. fastidiosa sample incubated for 4 days in the presence of $\left[1-{ }^{13} \mathrm{C}\right]$ acetate as the only source of carbon. The ${ }^{13} \mathrm{C}$ NMR spectrum (using a solution probe) of suspended bacteria in deuterated water is given in Fig. 1B, showing signals due to molecules soluble in water or with high inherent mobility. In this spectrum, besides several other compounds such as bicarbonate $(\delta 160.5)$, the characteristic peaks of cis mono-unsaturated fatty acids, like oleic, palmitoleic or vaccenic acids, with signals at $\delta 23,25,27,30,130$,

$\Lambda$

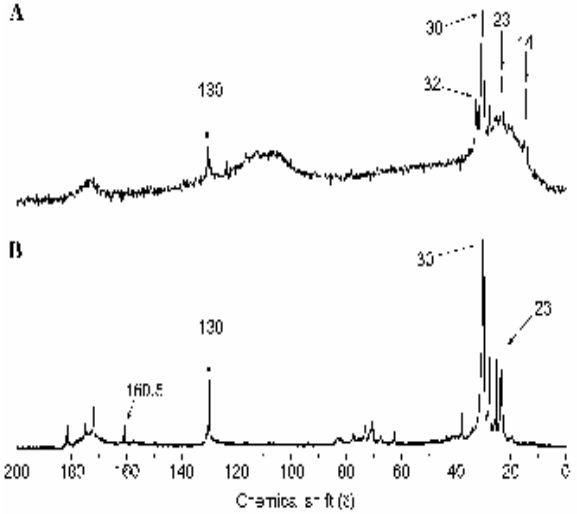

Fig. 1. (A) ${ }^{13} \mathrm{C}$ NMR spectrum of the lyophilized $X$. fastidiasa sample using a single pulse sequence combined with magic angle spinning. (B) ${ }^{13} \mathrm{C}$ NMR spectrum of $X$. fastidiasa in deuterated water suspension, after four days culture in enriched $\left[1{ }^{13}\right.$ C]acetate as a sole carbon source. and $\delta 172$, are clearly observable $[10,12,13]$. It also shows peaks from $\delta 60$ to $\delta 85$, related to glycerol and saccharide carbons.

Database searches and sequence alignment

A BLAST search against the $X$. fastidiosa genome using the E. coli YhhU gene product as probe identified the HetI protein (XF 1934) to be a distant homolog (32\% identity over 126 alignment positions) and therefore a potential 4'-phosphopantetheinyl transferase. No crystal structure is available for $\mathrm{YhhU}$, so the HetI sequence was subsequently used as probe against the PDB in the search for 4'-phosphopantetheinyl transferases of known crystal structure. The GenThreader and PsiBLAST algorithms aided in identifying and aligning Hetl to the surfactin synthetase-activating enzyme, Sfp, from B. subtilis, the only homolog of known three-dimensional structure. Fig. 2 shows the final alignment between HetI and Sfp in which the secondary structures derived from the crystal structure are identified. Here, we use a nomenclature for the secondary structures derived from the assignments in the header of the PDB file (1QR0), which differ slightly from those used by [24] in their original description of the structure. Only 40 of the 197 aligned residues are conserved, corresponding to an overall sequence identity of $20 \%$. These residues are not homogeneously distributed along the sequence but concentrate in the major elements of secondary structure. All residues identified as important for the binding of the pyrophosphate and adenine base of Coenzyme $\mathrm{A}$ are conserved or conservatively substituted in Hetl (Ser67, His68, Lys136, Gly51, Arg52, and Pro53) as are the acidic residues (Asp86, Glu88, and Glu132) responsible for the concomitant binding of $\mathrm{Mg}^{2+}$ (Fig. 2). Two major deletions are observed in Hetl, corresponding to the loss of 23 residues at the $\mathrm{N}$-terminus and 15 at the $\mathrm{C}$-terminus as compared to Sfp.

Quality of the model

The HetI model was built on the basis of the only available parent structure, Sfp, using the coordinate file of its complex with $\mathrm{CoA}(1 \mathrm{QR} 0)$ as described above. Stereochemical analysis of the final model using PROCHECK showed that $95.4 \%$ of the residues lie in the most favorable regions of the Ramachandran plot, with $3.6 \%$ in the additionally allowed regions and only $1.0 \%$ of outliers. Model validation using chemical environments as defined by VERIFY 3D yielded a total score of 53.6 compared with a mean expected score of 89.6 and a minimal acceptable score of 40.3 , for a protein of 197 residues. This suggests that the model has overall self-consistency in terms of sequence-structure compatibility. However, one region of the structure (His 147-Val161) was detected to be problematic by this method. This part of the structure corre- 


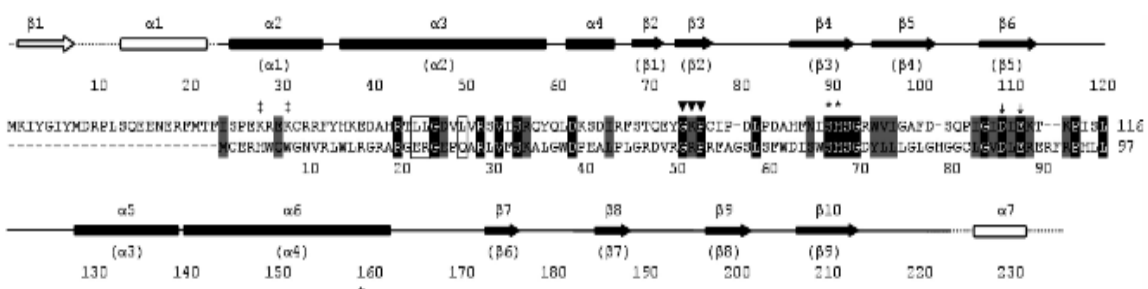

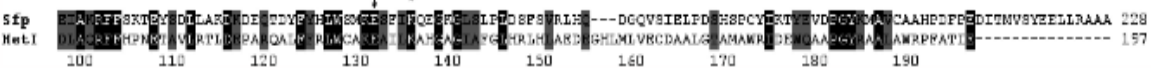

Fig. 2. The final sequence alignment for Sfp and HetI with the nomenclature for the secondary structural elements indicated (HetI in parentheses). Residue identities and conservative substitutions are shown with black and grey backgrounds, respectively. The $\mathrm{CoA} / \mathrm{Mg}^{2+}$ cofactor binding site is indicated in the following manner: conserved residues involved in binding the adenine base ( $\mathbf{V})$, the pyrophosphate group $\left(^{*}\right)$, and the $\mathrm{Mg}^{2+}(\downarrow)$. Lys28 and Lys31 of Sfp, which interact with the $3^{\prime}$ phosphate, are also indicated $(\$)$. The numbers which appear above the sequences refer to alignment positions and those below refer specifically to the Het sequence itself. The open boxed residues which appear in helix $\alpha 3$ of Sfp are hydrophobic residues which participate in the occluded face of the helix but which are solvent-exposed hydrophilic residues in HetI.

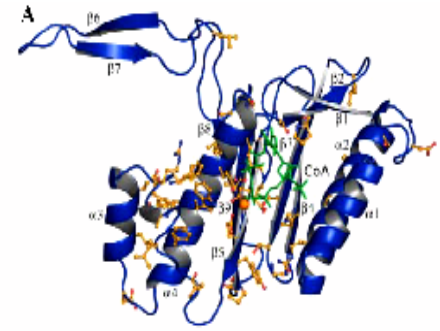

B

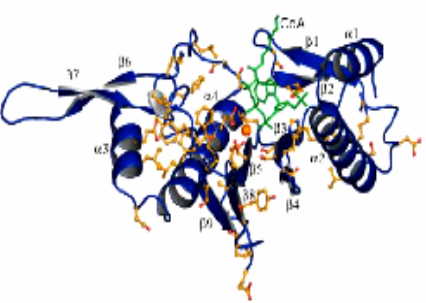

Fig, 3. Ribbon representation of HetI in two different views. The conserved residue side chains (orange), $\mathrm{CoA}$ (green), and the $\mathrm{Mg}^{2+}$ ion (orange sphere) are shown explicitly. Structural figures were generated with PyMOL [32]. (For interpretation of the references to colour in this figure legend, the reader is referred to the web version of this article.)

sponds to a protruding wing in the structure of Sfp, including strands $\beta 6$ and $\beta 7$ (Fig. 3). This unusual structure may be the result of crystal packing in the case of the parent structure Sfp, where these two $\beta$-strands form part of a four-stranded sheet with a symmetry-related molecule. The poor evaluation of this part of the HetI model in terms of residue envir onments is probably a consequence of this artifact and suggests that in solution this protrusion may not exist.

Atomic contact analysis of the model using the QUALTY option of the program WHATIF gave an overall mean value of -1.637 , which is acceptable given the reference values. Some regions of the structure show poor atomic contacts but these are generally loop regions and not important for Coenzyme A binding. Given the low sequence identity between parent structure and target, the representative model chosen for analysis appears to be of good overall quality.

\section{Overall description of the structure}

By definition the Hetl structure is similar to that of Sfp but with some notable differences. It is divided into two similarly folded domains of approximately equal size. The first domain corresponds to the $\mathrm{N}$-terminal half of the structure and extends from Metl to Asp86, while the C-terminal domain runs from Leu87 to Glu197. Each domain has a similar mixed $\alpha / \beta$ topology based on that originally described for Sfp, but modified as a consequence of two large deletions at the $\mathrm{N}$ - and $\mathrm{C}$-termini in Hetl, as described above. The main $\beta$-sheet in the $\mathrm{N}$-terminal domain is composed of the anti-parallel strands $\beta 3$ and $\beta 4$ (Figs. 2 and 3) which are packed against the corresponding sheet from the C-terminal domain (strands $\beta 5, \beta 8$, and $\beta 9$ ) forming an unusual wedge-shaped $\beta$-sandwich at the core of structure. Each domain has two large $\alpha$ helices packed against the external sides of this $\beta$-sandwich and two additional $\beta$-strands $(\beta 1 / \beta 2$ and $\beta 6 / \beta 7$, respectively) forming hairpins. In the $\mathrm{N}$-terminal domain this hairpin is folded back onto the body of the structure whilst in the C-terminal domain it protrudes into the solvent and corresponds to the region described above (147-161) which is poorly evaluated in terms of residue environments.

\section{$\mathrm{CoA} / \mathrm{Mg}^{2+}$ binding site}

Fig. 4 shows a schematic diagram of the HetI model including $\mathrm{CoA} / \mathrm{Mg}^{2+}$ bound to the structure. The 


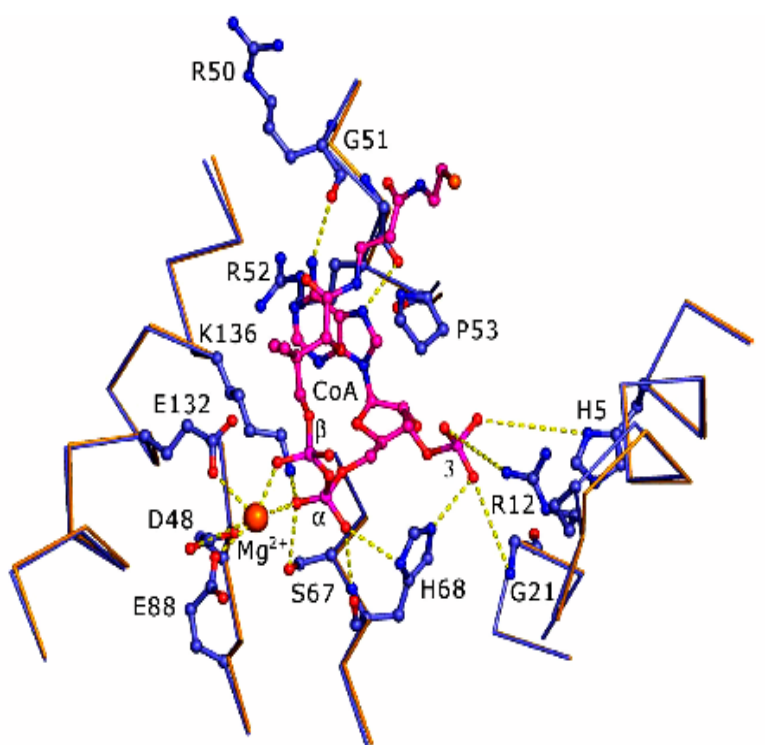

Fig. 4. The $\mathrm{CoA}$ (purpley $\mathrm{Mg}^{2+}$ (orange sphere) binding pocket of HetI. The C $\alpha$ trace of selected regions of HetI is shown in blue superposed on Sfp in orange. (For interpretation of the references to colour in this figure legend, the reader is refer red to the web version of this article.)

cofactor binding site is located at the exposed edge of the wedge-shaped $\beta$-sandwich (composed of strands $\beta 3$ and $\beta 5$ ), where the two sheets come closest together. Most of the intermolecular interactions observed in the Sfp structure are conserved in the complex HetI-CoA/ $\mathrm{Mg}^{2+}$, indicating that the cofactor would be expected to bind with similar affinity. Residues Gly51-Pro53 of HetI correspond to Gly74-Pro76 in Sfp in which the proline ring nestles between the ribose sugar and the adenine base of the CoA and Arg52 stacks across the latter in a manner similar to that of Lys75 in Sfp. Ser67, His68, and Lys136 (HetI numbering) are all conserved and play important roles in binding the CoA pyrophosphate and $3^{\prime}$-phosphate $\left(\mathrm{P}_{3}\right)$. Particularly important is His 68 whose $\mathrm{N}_{\mathrm{e} 2}$ forms a salt bridge with $\mathrm{P}_{3}$ and whose $\mathrm{N}_{81}$ and amide nitrogen bind the $\alpha$ phosphate. His68 is part of the largest single conserved stretch of residues (SHSG) whose serines appear to play an unusual structural role (see Discussion). CoA binding is further stabilized by the conserved acidic side chains of Asp86, Glu88, and Glu132 which directly coordinate the metal ion (supposedly $\mathrm{Mg}^{2+}$ ) which bridges the protein to the $\mathrm{COA}$ pyrophosphate group.

The only interactions important for $\mathrm{CoA}$ binding in Sfp which are not conserved in HetI are two lysine residues involved in salt bridges to the $3^{\prime}$-phosphate. The model suggests that this role may be assumed by basic residues such as His5 and Arg12 of HetI which lie approximately $5.5 \AA$ from the $3^{\prime}$-phosphate in the repre- sentative model but which could potentially interact directly via hydrogen bonds. Fig. 4 shows the predicted cofactor binding site.

\section{Discussion}

With the complete genome sequences of several strains of $X$. fastidiosa as well as related bacteria already published [1,2], future studies have now to focus on gene expression/regulation and in the identification of metabolites (metabolomics) and the enzymes necessary for their synthesis (proteomics). Here, we have concentrated specifically on fatty acid biosynthesis.

The ${ }^{13} \mathrm{C}$ NMR spectrum (Fig. 1A) shows the presence of the expected resonances for mono-unsaturated fatty acids in a dry sample of $X$. fastidiosa. Furthermore, the signals which remain after growing the bacteria in the presence of $\left[1-{ }^{13} \mathrm{C}\right]$ acetate as a sole source of carbon (Fig. 1B) are consistent with classical fatty acid synthesis from acetate. For example, as the fatty acid is elongated by adding $\left[1-{ }^{13} \mathrm{C}\right]$ acetate, it will not label the terminal methyl group (explaining the absence of a signal at $\delta 14$ ) or the methylene carbons at $\delta 32$ and $\delta 34$, assigned to ${ }^{13} \mathrm{CH}_{2}-\mathrm{CH}_{2}-\mathrm{CH}_{3}$, and ${ }^{13} \mathrm{C}_{2}$, respectively.

However, the absence in the spectra of Fig. 1A of the expected resonances associated with glycerol raises the question of the chemical nature of the fatty acids present. The lack of glycerol signals could be explained 
either by its lower mobility and stronger dipolar interaction or alternatively because the fatty acids are either free or present as part of structures which do not contain glycerol. The free fatty acid hypothesis was eliminated by extraction with chlor oform [12]. Furthermore, the fatty acids do not seem to be part of lipopolysaccharides, normally present in the cell wall of gram-negative bacteria like $X$. fastidiosa, since the fatty acids of lipid $\mathrm{A}$ are normally $\beta$ hydroxyl-myristic acids [33], which have very different chemical shift to those observed here.

On the whole, these data indicate that $X$. fastidiosa, as expected, is able to synthesize fatty acid, presumably present mainly in the form of membrane phospholipids, a vital component of almost all living organisms. The large amount of mono-unsaturated fatty acids in the membrane may be related to the lower growth temperature $\left(28^{\circ} \mathrm{C}\right)$ preferred by the bacterium $[34,35]$.

Normal fatty acid synthesis involves the initial activation of the acyl carrier protein (ACP) of the fatty acid synthase by the holo-acyl-carrier-protein synthase $(\mathrm{ACP})$ which transfers the phosphopantetheinyl arm derived from Coenzyme A onto a specific serine residue of the ACP. However, despite the fact that the X. fastidiosa genome encodes an acyl carrier protein, and is capable of fatty acid synthesis, it was originally reported to lack ACPs.

Classical ACPs molecules are symmetric homotrimers made of small ( 100 residue) subunits $[36,37]$ in which the active sites lie at the intersubunit interfaces, where $\mathrm{CoA}$ binds. However, a second family of phosphopantetheinyl transferase is described to be involved in processes such as the activation of peptide carrier proteins (PCP) of peptide synthetases [24], lysine biosynthesis in fungi [38], and cyanobacterial heterocyst differentiation [39]. Members of this second family are approximately twice the size of a normal ACPs but are monomeric enzymes, composed of two domains (structurally equivalent to two of the three subunits of $\mathrm{ACP}$ ) with an active site at their interface.

Escherichia coli possesses at least three enzymes capable of phosphopantetheinyl transfer, including one member of each of these two families. The YhhU gene product belongs to the second family and is less active than ACPs in activating ACP but can maintain an $E$. coli $\mathrm{ACPs}$ conditional lethal phenotype viable when expressed in higher concentration.

We propose here that HetI, the $X$. fastidiosa homolog of YhhU, may therefore represent one of the supposed missing links for fatty acid biosynthesis. However, the identification of a homolog is not sufficient to guarantee its functionality and this is particularly critical in the case of low sequence identity, as observed here. First the gene product must be structurally viable and second it must be catalytically active. The homology model of Hetl helps to address these questions, at least in part.
All validation methods applied to the selected representative model showed it to be acceptable. Furthermore, despite presenting only $20 \%$ sequence identity compared with the parent structure, Sfp, the pattern of sequence conservation is coherent. Besides those residues directly involved in $\mathrm{CoA}$ binding, the majority of conserved residues are either hydrophobic and participate in the core of the structure or appear to play specific structural roles, such as glycines with positive $\varphi$ angles or charged residues involved in salt bridges. Fig. 3 shows all such residues explicitly. Furthermore, the model suggests that His 5 and Arg12 may replace the only non-conserved $\mathrm{CoA}$ binding residues of Sfp, Lys28, and Lys 31 , in interacting with $\mathrm{P}_{3}$ (Fig. 4).

A further conserved structural feature is a series of serine sidechains which emanate from the inward pointing face of $\beta$-strand $\beta 3$ so as to form hydrogen bonds with the exposed amides of the adjacent edge strand $\beta 5$, which is part of the second $\beta$-sheet of the central sandwich. A BLASTp search of GenBank with HetI showed this SXSXS motif to be generally conserved and characteristic of most such phosphopantetheinyl transferase sequences, including ACPs. In some sequences, such as Sfp, one serine is replaced by an alternative amino acid with similar hydrogen-bonding potential (Asn, Asp, and Thr). However, a search of the PDB using the PATTINPROT software [40] shows this motif, which we term a serine ladder, to be unique to such molecules and is probably correlated to the wedge-like arrangement of the $\beta$-sandwich which favors the correct orientation of the serine side chains with respect to the leftover amides of the adjacent edge strand. No similar mechanism has thus far been described for satisfying or hiding edge-strand hydrogen-bonding potential [41] (Fig. 5).

Nevertheless, one major difference was noted between HetI and Sfp; the fact that the former is approximately 40 residues shorter due to deletions at both the $\mathrm{N}$ - and C-termini. The structural consequences of these deletions (Figs. 2 and 6 ) are the loss of a $\beta$-strand, two $\alpha$-helices, and connecting loops at each end of the molecule. These regions are spatially proximal and in Sfp cover one side of the large buried helix $\alpha 3$. Their deletion leads to the solvent exposure of the equivalent helix in HetI $(\alpha 2)$ which has suffered a series of compensatory mutations. Leu45, Leu46, and Leu50 in Sfp have been replaced by Glu22, Arg23, and Gln27 on the exposed side of $\alpha 2$ in Hetl, consistent with the $\mathrm{N}$ - and $\mathrm{C}$-terminal deletions.

Overall, these observations appear to suggest that the HetI gene product should be both structurally viable and catalytically active. However, it would appear to present a somewhat simplified fold compared to Sfp. At this stage it is difficult to know what might be the metabolic consequences of this, if any. However, the observation that the YhhU protein in E coli is less 


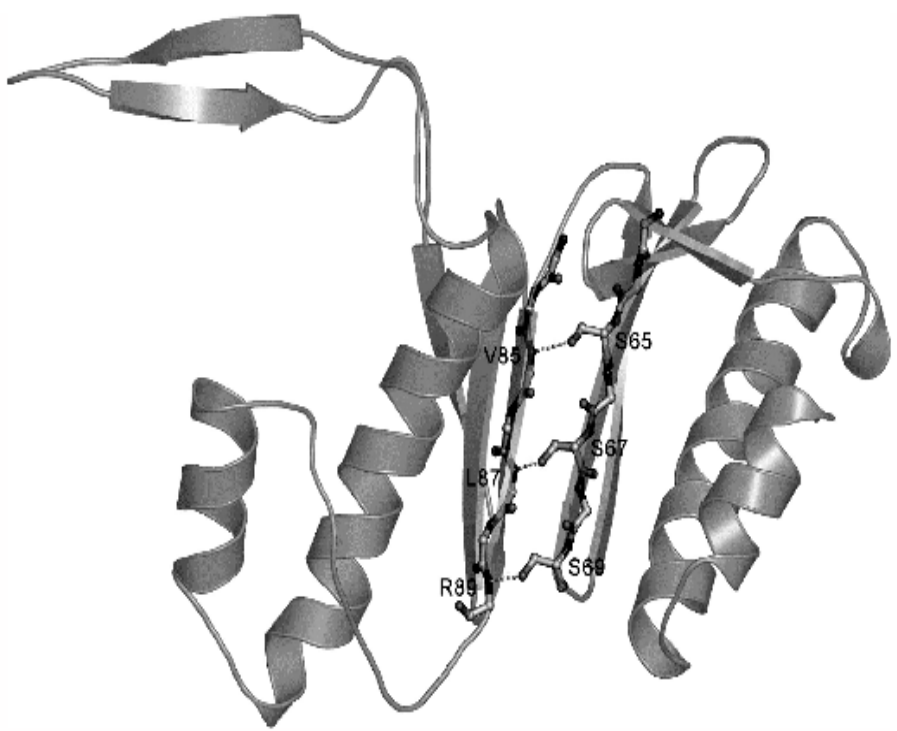

Fig. 5. The serine ladder. The side chains of serines 65,67 , and 69 in $\beta 3$ in one $\beta$-sheet form hydrogen bonds with the free main chain amides from edge strand $\beta 5$ of the other shoet of the wedge-like sandwich.
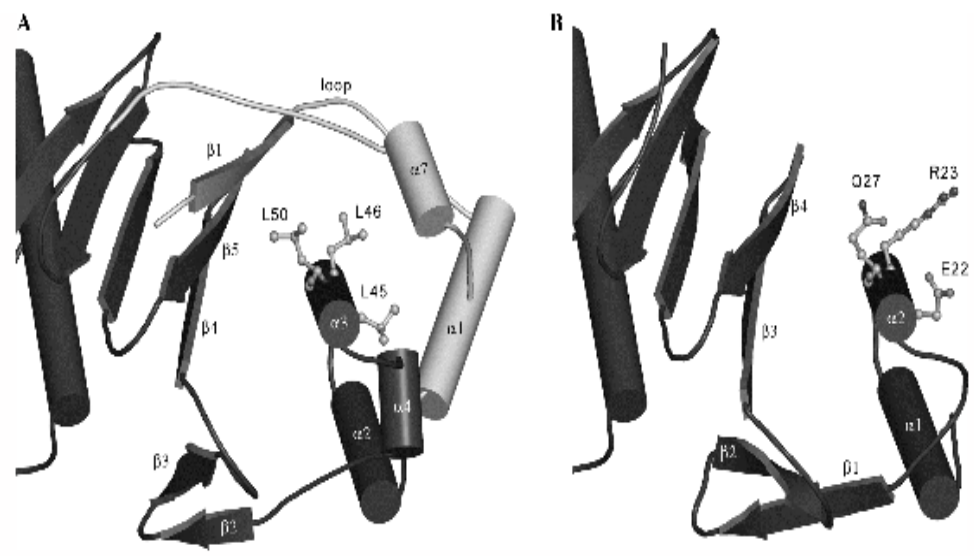

Fig. 6. Ribbons figure of part of the Sfp structure centered on the buried $\alpha 3$ helix (A) compared with the exposed homologous helix, $\alpha 2$ in Hetl (B). The elements of structure shown in light grey in Sfp are absent from Hetl due to large $\mathrm{N}$ - and C-terminal deletions. Selected residues which are different in the two molecules are highlighted in ball-and-stick.

efficient in modifying ACP compared with ACPs suggests that a less than optimal production of holo-ACP in $X$. fastidiosa, and consequently a reduced level of fatty acid, phospholipid, and lipopolysaccharide synthesis, may be one of the causes for the slow growth rate of the bacterium in vivo and in vitro.

Clearly the Hetl gene product now needs to be expressed and biochemically characterized in order to elucidate its full role in $X$. fastidiosa metabolism. It is even possible that it serves as a generic phosphopantetheinyl transferase for more than one substrate given that it is the only such molecule thus far identified in $X$. fastidiosa. Recently, interest in novel phosphopantetheinyl transferases capable of activating the PCP domains of non-ribosomal peptide sythetases is growing due to the search for broad specificity enzymes which have potential applications in the in vivo synthesis of novel biotechnologically interesting oligopeptide metabolites. The apparently simplified version of a phosphopantetheinyl transferase, represented by HetI, means, at the very least, that it merits further investigation. 


\section{Acknowledgments}

We thank FAPESP, CAPES, and CNPq for financial support.

\section{References}

[1] A.J.G. Simpson, F.C. Reinach, P. Arruda, F.A. Abreu, M. Acencio, R. Alvarenga, L.M.C. Alves, J.E. Araya, G.S. Baia, C.S. Baptista, M.H. Barros, E.D. Bonaccorsi, S. Bordin, J.M. Bove, M.R.S. Briones, M.R.P. Bueno, A.A. Camargo, L.E.A. Camargo, D.M. Carraro, H. Carrer, N.B. Colauto, C. Colombo, F.F. Costa, M.C.R. Costa, C.M. Costa-Neto, L.L. Coutinho, M. Cristofani, E. Dias-Neto, C. Docena, H. El Dorry, A.P. Facincani, A.J.S. Ferreira, V.C.A. Ferreira, J.A. Ferro, J.S. Fraga, S.C. Franca, M.C. Franco, M. Frohme, L.R. Furlan, M. Garnier. G.H. Goldman, M.HS. Goldman, S.L. Gomes, A. Gruber, P.L. Ho, J.D. Hoheisel, M.L. Junqueira, E.L. Kemper, J.P. Kitajima, J.E. Krieger, E.E. Kuramae, F. Laigret, M.R. Lambais, L.C.C. Leite, E.G.M. Lemos, M.V.F. Lemos, S.A. Lopes, C.R. Lopes, J.A. Machado, M.A. Machado, A.M.B.N. Madeira, H.M.F. Madeira, C.L. Marino, M.V. Marques, E.A.L. Martins, E.M.F. Martins, A.Y. Matsukuma, C.F.M. Menck, E.C. Miracca, C.Y. Miyaki, C.B. Monteiro-Vitorello, D.H. Moon, M.A. Nagai, A.L.T.O. Nascimento, L.E.S. Netto, J. Nhani, F.G. Nobrega, L.R. Nunes, M.A. Oliveira, M.C. de Oliveira, R.C. de Oliveira, D.A. Palmieri, A. Paris, B.R. Peixoto, G.A.G. Pereira, J. Pereira, J.B. Pesquero, R.B. Quaggio, P.G. Roberto, V. Rodrigues, A.J.D. Rosa, V.E. de Rosa, R.G. de Sa, R.V. Santelli, H.E. Sawasaki, A.C.R. da Silva, F.R. da Silva, A.M. da Silva, J. Silva, J.F. da Silveira, M.L.Z. Silvestri, W.J. Siqueira, A.A. de Souza, A.P. de Souza, M.F. Terenzi, D. Truffi, S.M. Tsai, M.H. Tsuhako, H. Vallada, M.A. Van Sluys, S. Verjovski-Almeida, A.L. Vettore, M.A. Zago, M. Zatz, J. Meidanis, J.C. Setubal, The genome sequence of the plant pathogen Xylella fastidiasa, Nature 406 (2000) 151-157.

[2] M.A. Van Sluys, M.C. de Oliveira, C.B. Monteiro-Vitorello, C.Y, Miyaki, L.R. Furlan, L.E. Camargo, A.C. da Silva, D.H. Moon. M.A. Takita, E.G. Lemos, M.A. Machado, M.I. Ferro, F.R. da Silva, M.H. Goldman, G.H. Goldman, M.V. Lemos, H. ElDorry, S.M. Tsai, H. Carrer, D.M. Carraro, R.C. de Oliveira, L.R. Nunes, W.J. Siqueira, L.L. Coutinho, E.T. Kimura, E.S. Ferro, R. Harakava, E.E. Kuramae, C.L. Marino, E. Giglioti, I.L. Abreu, L.M. Alves, A.M. do Amaral, G.S. Baia, S.R. Blanco, M.S. Brito, F.S. Cannavan, A.V. Celestino, A.F. da Cunha, R.C. Fenille, J.A. Ferro, E.F. Formighieri, L.T. Kishi, S.G. Leoni, A.R. Oliveira, V.E. Rosa Jr., F.T. Sassaki, J.A. Sena, A.A. de Souza, D. Truffi, F. Tsukumo, G.M. Yanai, L.G. Zaros, E.L. Civerolo, A.J. Simpson, N.F. Almeida Jr., J.C. Setubal, J.P. Kitajima, Comparative analyses of the complete genome sequences of Pierce's disease and citrus variegated chlorosis strains of Xylella fastidiasa, J. Bacteriol. 185 (2003) 1018-1026.

[3] C.O. Rock, S. Jackowski, Forty years of bacterial fatty acid syn thesis, Biochem. Biophys. Res. Commun. 292(2002) 1155-1166.

[4] A. Bhattacharyya, S. Stilwagen, G. Reznik, H. Feil, W.S. Feil, I. Anderson, A. Bernal, M. D'Souza, N. Ivanova, V. Kapatral, N. Larsen, T. Los, A. Lykidis, E. Selkov Jr., T.L. Walunas, A. Purcell, R.A. Edwards, T. Hawkins, R. Haselkorn, R. Overbeck, N.C. Kyrpides, P.F. Predki, Draft sequencing and comparative genomics of Xylella fastidiasa strains reveal novel biological insights, Genome Res. 12 (2002) 1556-1563.

[5] E.G.M. Lemos, L.M.C. Alves, J.C. Campanharo, Genomics based design of defined growth media for the plant pathogen Xylella fastidiasa, FEMS Microbiol. Lett. 219 (2003) 39-45.
[6] M.B. Smolka, D. Martins, F.V. Winck, C.E. Santoro, R.R. Castellari, F. Ferrari, I.J. Brum, E. Galembeck, H.D. ColettaFilho, M.A. Machado, S. Marangoni. J.C. Novello, Proteome analysis of the plant pathogen Xylella fastidiosa reveals major cellular and extracellular proteins and a peculiar codon bias distribution, Proteomics 3 (2003) 224-237.

[7] A.P. Facincani, J.A. Ferro, J.M. Pizauro Jr., H.A. Perreira Jr., E.G.M. Lemos, A.L. do Prado, M.I.T. Ferro, Carbohydrate metabolism of Xylella fastidiasa: detection of glycolytic and pentose phosphate pathway enzymes and cloning and expression of the enolase gene, Genet. Mol. Biol. 26 (2003) 203-211.

[8] C. de Pieri, L.M. Beltramini, H.S. Selistre-de-Araújo, A.L. Vettore, F.R. da Silva, P. Arruda, G. Oliva, D.H.F. de Souza, Overexpression, purification, and biochemical characterization of GumC, an enzyme involved in the biosynthesis of exopolysaccharide by Xylella fastidiosa, Protein Expr. Purif. 34 (2004) 223 228.

[9] D. Osiro, L.A. Colnago, A.M.M.B. Otoboni, E.G.M. Lemos, A.A. Souza, H.D. Colctta Filho, M.A. Machado, A kinetic model for Xylella fastidiosa adhesion, biofilm formation, and virulence, FEMS Microbiol. Lett. 236 (2004) 313-318.

[10] L.A. Colnago, P.R. Seidl, Application of carbon-13 nuclear magnetic resonance to the germination of soybean seeds in vivo, J. Agric. Food Chem. 31 (1983) 459-461.

[11] K. Shon, Y. Kim, L.A. Colnago, S.J. Opella, NMR studies of the structure and dynamics of membrane bound bacteriophage Pf1 coat protein, Science 252 (1991) 1303-1305.

[12] L.A. Forato, L.A. Colnago, R.C. Garratt, M.A. Lopes, Identification of free fatty acids in maize protein bodies and purified alpha zeins by ${ }^{13} \mathrm{C}$ and ${ }^{1} \mathrm{H}$ nuclear magnetic resonance, Biochim. Biophys. Acta 1543 (2000) 106-114.

[13] L.A. Forato, V. Yushmanov, L.A. Colnago, Interaction of two prolamins with $\left[1-{ }^{13} \mathrm{C}\right]$ oleic acid by ${ }^{13} \mathrm{C}$ NMR, Biochemistry 43 (2004) 7121-7126.

[14] D.G. Gadian, NMR and its Applications to Livings Systems. second ed., Oxford University Press, New York, 1995.

[15] M.J. Davis, W.J. French, N.W. Schaad, Axenic culture of the bacteria associated with phony disease of peach and plum leaf scald, Curr. Microbiol. 6 (1981) 309-314.

[16] L.A. Colnago, K.G. Valentine, S.J. Opella, Dynamics of the fd coat protein in the bacteriophage, Biochemistry 26 (1987) 847853.

[17] R.S. Fluegl, Y. Hwangbo, R.H. Lambalot, J.E. Cronan, C.T. Walsh, Holo-(acyl carrier protein) synthase and phosphopantetheinyl transfer in Escherichia coli, J. Biol. Chem, 275 (2000) 959 968.

[18] Available from: <http://acg,lbi.ic.unicamp.br/xp $>$.

[19] S.F. Altschul, W. Gish, W. Miller, E.W. Myers, D.J. Lipman, Basic local alignment search tool, J. Mol. Biol. 215 (1990) 403410.

[20] Available from: <http://www.ncbinlm.nih.gov>.

[21] D.T. Jones, Protein secondary structure prediction based on position-specific scoring matrices, J. Mol. Biol. 292 (1999) 195 202.

[22] S.F. Altschul, T.L. Madden, A.A. Schäffer, J. Zhang, Z. Zhang, W. Miller, D.J. Lipman, Gapped BLAST and PSI-BLAST: a new generation of protein database search programs, Nucleic Acids Res. 25 (1997) 3389-3402.

[23] H.M. Berman, J. Westbrook, Z. Feng, G. Gilliland, T.N. Bhat, H. Weissig, I.N. Shindyalov, P.E. Bourne, The protein data bank, Nuckic Acids Res, 28 (2000) 235-242.

[24] K. Reuter, M.R. Mofid, M.A. Marahiel, R. Ficner, Crystal structure of the surfactin synthetase-activating enzyme sfp: a prototype of the 4'-phosphopantetheinyl transferase superfamily, EMBO J. 18 (1999) 6823-6831.

[25] A. Sali, T.L. Blundell, Comparative protein modelling by satisfaction of spatial restraints, J. Mol. Biol. 234 (1993) 779-815. 
[26] B.R. Brooks, R.E. Bruccoleri, B.D. Olafson, D.J. States, S. Swaminathan, M. Karplus, CHARMM: a program for macromolocular energy, minimization, and dynamics calculations, J. Comp. Chem. 4 (1983) 187-217.

[27] R.A. Laskowski, M.W. MacArthur, J.M. Thornton, Validation of protein models derived from experiment, Curr. Opin. Struct. Biol. 8 (1998) 631-639.

[28] R. Luthy, J.U. Bowie, D. Eisenberg, Assessment of protein models with three-dimensional profiles, Nature 356 (1992) 83-85.

[29] G. Vriend, C. Sander, Quality control of protein models: directional atomic contact analysis, J. Appl. Crystallogr. 6 (1993) 47-60

[30] G. Vriend, What if: a molecular modeling and drug design program, J. Mol. Graph. 8 (1990) 52-56.

[31] A.H. Purcell, D.L. Hopkins, Fastidious xylem-limited bacterial plant pathogens, Annu. Rev. Phytopathol. 34 (1996) 131-151.

[32] W.L. DeLano, The PyMOL Molecular Graphics System. DeLano Scientific LLC, San Carlos, CA, USA. Available from: <http:// www.pymol.org>.

[33] A. Bhattacharyya, S. Stilwagen, N. Ivanova, M. D'Souza, A. Bernal, A. Lykidis, V. Kapatral, I. Anderson, N. Larsen, T. Los, G. Rezrik, E. Selkov Jr., T.L. Walunas, H. Feil, W.S. Feil, A Purcell, J.-L. Lassez, T.L. Hawkins, R. Haselkorn, R. Overbeek, P.F. Predki, N.C. Kyr pides, Whole-gen ome comparative analysis of three phytopathogenic Xylella fastidiosa strains, Proc. Natl. Acad. Sci. USA 99 (2002) 12403-12408.
[34] D.A. Los, N. Murata, Structure and expression of fatty acid desaturases, Biochim. Biophys. Acta 1394 (1998) 3-15.

[35] N. Murata, D.A. Los, Membrane fluidity and temperature perception, Plant Physiol, 115 (1997) 875-879.

[36] K.D. Parris, L. Lin, A. Tam, R. Mathew, J. Hixon, M. Stahl, C.C. Fritz, J. Seehra, W.S. Somers, Crystal structures of substrate binding to Bacillus subtilis holo-(acyl carrier protein) synthase reveal a novel trimeric arrangement of molecules resulting in three active sites, Structure 8 (2000) 883-895.

[37] N.Y. Chirgadze, S.L. Briggs, K.A. McAllister, A.S. Fischl, G. Zhao, Crystal structure of Streptococus pneumoniae acyl carrier protein synthase: an essential enzyme in bacterial fatty acid biosynthesis, EMBO J. 19 (2000) 5281-5287,

[38] D.E. Ehmann, A.M. Gehring, C.T. Walsh, Lysine biosynthesis in Saccharamyces arevisiae: mechanism of $\alpha$-aminoadipate reductase (Lys2) involves posttranslational phosphopantetheinylation by Lys5, Biochemistry 38 (1999) 6171-6177.

[39] T.A. Black, C.P. Wolk, Analysis of a $\mathrm{Het}^{-}$mutation in Anabaena sp. strain PCC 7120 implicates a secondary metabolite in the regulation of heterocyst spacing, J. Bacteriol. 176 (1994) 2282 2292.

[40] C. Combet, C. Blanchet, C. Geourjon, G. Deléage, Network protein sequence analysis, TIBS 25 (2000) 147-150.

[41] J.S. Richardson, D.C. Richardson, Natural $\beta$-sheet proteins use negative design to avoid edge-to-edge aggregation, Proc. Natl. Acad. Sci. USA 99 (2002) 2754-2759. 


\title{
Translation initiation in Leishmania major: characterisation of multiple eIF4F subunit homologues
}

\author{
Rafael Dhalia a, , Christian R.S. Reis ${ }^{b, c}$, Eden R. Freire ${ }^{b, c}$, Pollyanna O. Rocha ${ }^{b, c}$, \\ Rodolfo Katz ${ }^{b, c}$, João R.C. Muniz ${ }^{c}$, Nancy Standart ${ }^{d}$, Osvaldo P. de Melo Neto,* \\ "Departamento de Biologia Celular, Universidade de Brasilia, Brasilia 70910-900, D.F., Brajil \\ Received 14 Augurt 2004: received in revised form 25 November 2004: accepted 7 December 2004 \\ Available online 29 December 2004
}

\section{Abstract}

In eukaryotes protein synthesis initiates with the binding of the multimeric translation initiation complex eIF4F - eIF4E, eIF4A and eIF4G - to the monomethylated cap present on the $5^{\prime}$ end of mRNAs. eIF4E interacts directly with the cap nucleotide, while eIF4A is a highly conserved RNA helicase and eIF4G acts as a scaffold for the complex with binding sites for both eIF4E and eIF4A. eIF4F binding to the mRNA recruits the small ribo somal subunit to its $5^{\prime}$ end. Little is known in detail of protein synthesis in the protozoan parasites belonging to the family Trypanosomatidae. However, the presence of the highly modified cap structure, cap4, and the spliced leader sequence on the 5' ends of all mRNAs suggests possible differences in mRNA reciuitment by ribo somes. We identified several potential eIF4F homologues by searching Leishmania major databases: four eIF4Es (LmEIF4E1-4), two eIF4As (LmEIF4A1-2) and five eIF4Gs (LmEIF4G1-5). We report the initial characterisation of $L m E I F 4 E 1-3, L m E I F 4 A 1-2$ and $L m E I F 4 G 3$. First, the expression of these proteins in $L$. major promastigotes was quantitated by Western blotting using isoform specific antibodies. $L m E I F 4 A 1$ and $L m E I F 4 E 3$ are very abundant, $L m E I F 4 G 3$ is moderately abundant and $L m E I F 4 E 1 / L m E I F 4 E 2 / L m E I F 4 A 2$ are rare or not detected. In cap-binding assays, only LmEIF4E1 bound to the 7-methyl-GTPSepharose resin. Molecular modelling confirmed that LmEIF4E1 has all the structural features of a cap-binding protein. Finally, pull-down assays were used to investigate the potential inter action between the eIF4A ( LmEIF4A1/LmEIF4A2) and eIF4G (LmEIF4G1-3) homologues. Only $L m E I F 4 G 3$, via the HEAT domain, bound specifically both to $\mathrm{LmEIF} 4 \mathrm{~A} 1$ as well as to human eIF4A. Therefore for each factor, one of the $L$ major forms seems to fulfil, in part at least, the expected characteristics of a translational initiation factor. Q 2004 Elsevier B.V. All rights re served.

Reywords: efF4F; Tranclation initiation; Leishnania major, Protein-protein interaction

\section{Introduction}

Flagellate protozoans belonging to the order Kinetopias tida, family Trypanosomatidae, are responsible for a series of important diseases, such as the Leishmaniasis, Sleep-

+ Corresponding author. Tel.: +55 812101 2636; fax: +5581 34532449 E-mail address: opmn@epqum fiocruz. br (OP. de Melo Neto).

166-6851\$ - gee front matter 02004 Elgevier B.V. All rights reserved doi:10.1016/j mol biopura.2004.12.001 ing Sickness and Chagas' Disease, which affect millions of people world-wide and put a great number of lives at risk (http://www.who.int/tdr). These are unique eukaryotes which are characterised by unusual processes in the formation of mature mRNAs, including polycistronic transcription and trans-splicing [1,2] (for recent reviews see [3,4]). These parasites are also distinguished by the lack of known mechanisms for the transcriptional control of the expression of 
their protein coding genes (reviewed in [5]). Processing of the polycistronic precursor mRNAs by trans-splicing adds the capped $39 \mathrm{nt}$ long spliced leader (SL or mini-exon sequence) to the $5^{\prime}$ end of each monocistronic mature mRNA. The first $4 \mathrm{nt}$ of the SL sequence are subject to various modifications and constitute, with the 7-methyl-GTP nucleotide at its $5^{\prime}$ end, the structure called cap4 $[6,7]$. Roles for the capped SL sequence in mRNA metabolism have been proposed, based largely on cap functions in metazoans, in mRNA transport, stability and/or translation, but no firm conclusions have been re ached yet. Experiments using antisense oligonucle otides complementary to the SL sequence in heterologous cell-free translation systems are suggestive of a role for this sequence in translation [8,9]. Indirect evidence from nematodes, using mess age-dependent homologous protein synthesis systems, also reinforces a role in translation [10]. Indeed recent data suggests that either the SL sequence or the cap4 is responsible for polysome association of mRNA in $L$. tarentolae [11]. Since the 5' end of most eukaryotic mRNAs is required for translation initiation, it is expected that their influence would be exerted at this stage of the translation process.

In animals, yeast and plants, the highly regulated initiation stage of protein synthesis starts with the binding of $e I F 4 F$ (formed by the translation initiation factors eIF4E, eIF4A and eIF4G) to the monomethylated cap present on the $5^{\prime}$ end of the mRNAs [12]. With the help of other initiation factors, such as eIF3, eIF4F allows the recognition of the mRNAs by the 40 S ribosomal subunit and the start of the translation process. Its interaction with the poly $(\mathrm{A})$-binding protein (PABP), via eIF4G, may also promote the circularization of the $\mathrm{mRNA}$ and enhance translation reinitiation (reviewed in [13-15]). eIF4E is a $24 \mathrm{kD}$ a polypeptide responsible for specific cap recognition. It binds to both the cap and eIF $4 \mathrm{G}$ and its activity can be regulated by phosphorylation or through the eIF4E interacting proteins (reviewed in [16-18]). eIF4A is an ATP-dependent RNA helicase which has beenclassified as a member of the DEAD box family of RNA helicases (reviewed in [19-21]). During translation initiation eIF4A binds eIF4G and, with the help of another translation initiation factor eIF4B, is responsible for melting seconday structures along the mRNA 5'UTR which allows the recruitment and scanning of the small ribosomal subunit to the translation initiation codon. The large subunit eIF4G (approximately $200 \mathrm{kDa}$ ) provides the scaffold for the eIF4F complex (reviewed in [22]). Through its N-terminus, eIF4G binds both eIF4E [23] and PABP [24,25], providing the link between the $5^{\prime}$ and $3^{\prime}$ ends of the mRNA. eIF4G's central core region includes the conserved HEAT repeat domain (also known as MIF4G/NIC1) [26], which is responsible for the interaction with eIF4A and RNA-binding, and also mediates the interaction with eIF3 [27,28], which recruits the 40.S ribosomal subunit. Mammalian eIF4G contain a C-terminal domain with a second eIF4A binding site as well as the binding site for the eIF4E kinase Mnk. Yeast eIF4G lacks this C-terminal domain [29-31].
Knowledge about the process of protein synthesis in trypanosomatid protozoans is inferred by indirect evidence such as sequence similarities between individual translation factors with homologues from higher eukaryotes. Translation factors characterised so far from the se organisms include subunits of elongation factors such aseEFl and eEF2 [32] and the PABP from T. cruzi,T. brucei and Leishmania major [33-35]. The eIF4A component of the eIF $4 \mathrm{~F}$ complex has also been identified both in L. major [36] and in L. braziliensis, as an antigen that elicits IL-12 production and Thl-type response in humans [37]. However, little is known regarding the role of these factors in translation.

To understand translation initiation in the trypanosomatids, we set out to characterise the various eIF $4 \mathrm{~F}$ subunits from L. major. Multiple potential homologues for the three eIF4F components were identified. These homologues seem to vary in different aspects such as cap binding affinity of the eIF4Es, levels of expression and interaction with other components of eIF4F. Our results suggest a high degree of complexity in translation initiation in these parasites, which may reflect an adaptation to their complex life cycle.

\section{Materials and methods}

\subsection{Parasites}

Promastigotes of $L$ major (MHOM/IL/81/Friedlin) were maintained at $26^{\circ} \mathrm{C}$ in modified LIT medium pH $7.2(0.2 \%$ sucrose (w/v); $0.36 \%$ liver broth $(\mathrm{w} / \mathrm{v}) ; 0.1 \%$ tryptose $(\mathrm{w} / \mathrm{v})$; $0.002 \%$ haemin $(w / v))$ containing $20 \%$ foetal bovine serum, ampicillin $(10 \mathrm{U} / \mathrm{ml})$ and streptomycin $(10 \mu \mathrm{g} / \mathrm{ml})$. Parasites were kept on continuous log phase growth by changing the culture media every 3-4 days. Total protein lysates were obtained from log phase haemocytometer quantified parasite cell pellets resuspended directly in SDS-PAGE sample buffer.

\subsection{Sequence analysis and modelling}

BLAST searches were carried out for possible L. major eIF4F subunit homologues at the GenBank databases (http:// www.ncbi.nlm.nih.gov) using as query the sequences of the humn and Saccharomyces cerevisae proteins. Similar searches were also initially performed with the nonannotated draft $L$. major and $T$. brucei genome databases (http://www.sanger.org), and later with those available at the Gene DB website of the Sanger Institute Pathogen Sequencing Unit (http://www.genedb.org). Sequences were aligned with Clustal W (http://www.cmbi.kun.nl/bioinf/ tools/clustalw.shtml); occasionally manual refinement of the alignments was performed. For the eIF4A sequence analysis, the alignment produced with CLUSTAL W was followed by phylogenetic and molecular evolutionnry analyses conducted with the program MEGA version 2.1 [38] using the Neighbour-Joining method [39]. Gaps were treated as miss- 
ing data. Bootstrap analysis (10,000 replicates) was done by interior branch test.

For the molecular modelling of LmEIF4E1 and the LmEIF4G3 HEAT domain, structural alignments were performed with the GenTHREADER program [40] comparing their secondary structure with that of available proteins with resolved structure. Best matches were the mouse eIF4E bound to 7-methyl-GDP [41] and the human eIF4GII HEAT domain [26], respectively. The atomic coordinates from these structures were submitted with the alignment results to the program MODELLER [42] in order to produce the models, which were then validated using the programs PROCHECK [43], Verify 3D [44] and WHATIF [45]

\subsection{PCR and cloning methods for the various L. majo factors}

The LmEIF4E1, LmEIF4E2, LmEIF4E2b (same as LmEIF4E2 but missing the $5^{\prime}$ end coding for the first seven amino acids of the protein), LmEIF4E3 and LmEIF4AI coding sequences were amplified using primers flanked by sites for the restriction enzymes $K p n I / X b a I$ ( $L m E I F 4 E 2$ ) or BamHI/XbaI (all others) and cloned into the corresponding restriction sites of the pGEM $3 z f+$ vector obtained from Promega (the sequences of all the oligonucle otides described in this work are listed on the supplementary table). The resulting full length sequences were then reamplified flanked by sites for AfIIII/NotI (LmEIF4EI), NcoI/NotI (LmEIF4E2 and LmEIF4E3-in the latter a N to D mutation was introduced in the second codon to accommodate the NcoI site) or NcoI/XhoI (LmEIF4AI) and cloned into the NcoI/NotI or NcoI/XhoI sites of the expression vector pET21D (Novagen) for the expression of recombinant C-terminal His-tagged proteins. For the expression of N-terminal Glutathione S-transferase (GST) fusions, fragments LmEIF4EI and LmEIF 4E2b were recovered from the pGEM derived plasmids and subcloned into the BamHU/SalI sites of the vector pGEX4T3 (Amersham Biosciences). For the same reason LmEIF4E3 and LmEIF $4 A I$ were reamplified fl anked by sites for $B a m H I / N o t I$ and BamHI/XhoI, respectively and cloned into the same sites of the pGEX4T3 vector. LmEIF4AI was further subcloned into the same sites of the pRSETA plasmid (Invitrogen) for the expression of N-terminal His-tagged proteins. The LmEIF 4A2 gene was amplified flanked by sites for BamHI/XhoI and cloned directly into the same sites of the vectors $p R$ SETA and pGEX4T3.

Fragments coding for the HEAT repe ats domain from the LmEIF4G1-3 homologues, LmEIF4G1 $128-475$ (the numbers indicate the amino acids remaining from the wild type protein), LmEIF4G2337-705 (missing the last 22 amino acids from the HEAT domain in Fig. 7) and LmEIF4G326-310, flanked by sites for AfiII/NotI (LmEIF4GI $128-475$ ) or NcoI/NotI (the others), were amplified and cloned into the NcoI/NotI sites of the pET21D plasmid for the expression of C-terminal His-tagged proteins. For both LmEIF4G2357-705 and LmEIF4G326-310, an AUG start codon was introduced in the constructs with the NcoI site. The full length LmEIF 4G3 (LmEIF4G3 ${ }_{1-636}$ ), as well as its first half ( LmEIF4 G3 $_{1-343}$ ) were also amplified and cloned into the same sites of pET21D. The latter two fragments were then reamplified and cloned into the BamHI/NotI sites of pGEX4T3 to have both proteins as GST fusions.

All of the amplified fragments above were sequenced and the resulting sequences confirmed by comparison with those from the L. major genome sequencing project.

\subsection{Cap binding assay}

${ }^{35}$ S-Met-labelled L major eIF4E proteins were synthesised in the TnT T7 Coupled Reticulocyte Lysate System (Promega) using the pET derived plasmids as templates. As a positive control, a Xenopus laevis eIF4E CDNA, in PSP64TEN, was recovered by digestion with HinDIII/Bg/II and subcloned into the HinDII/BamHI sites of pGEM2 (Promega) under control of the T7 promoter. For the cap binding ass ay, $35 \mu \mathrm{l}$ of 7 -me thyl-GTP Sepharose $4 \mathrm{~B}$ beads (Amersham Biosciences), previously equilibrated with buffer A (50 mM Hepes; $1 \mathrm{mM}$ EDTA; $0.1 \mathrm{mM}$ GTP; $14 \mathrm{mM}$ 2-mercaptoethanol; $100 \mathrm{mM} \mathrm{KCl}$; $\mathrm{pH} 7.4$ ), was mixed with $25 \mu \mathrm{l}$ of the translation products (in $200 \mu \mathrm{l}$ final volume-completed with buffer A) and incubated for $30 \mathrm{~min}$ in ice. The beads were then washed three times with $500 \mu \mathrm{l}$ buffer $\mathrm{A}$ and, for the elution, three times with $50 \mu \mathrm{l}$ buffer A containing $50 \mu \mathrm{M}$ cap analogue $\left(\mathrm{m}^{7} \mathrm{G}\left(5^{\prime}\right) \mathrm{ppp}\left(5^{\prime}\right) \mathrm{G}\right.$ (New England Biolabs) instead of the GTP. Any labelled protein still remaining on the beads was recovered with two final washes with $2 \mathrm{M} \mathrm{KCl}$ and SDS-PAGE sample buffer, respectively. Aliquots of all fractions were mixed with SDS sample buffer and analysed by SDS-PAGE and autoradiography.

\subsection{Expression and purification of recombinant proteins}

For the expression of either His or GST-tagged recombimant proteins, plasmids were transformed into Escherichia coli BLR or BL21 cells. The transformed bacteria were grown in LB medium and induced with IPTG. Induced cells were sedimented, resuspended in PBS and lysed by sonication or French press. Protein purification was performed as described [46] with either Ni-NTA Agarose (Qiagen) or glutathione-Sepharose (Amersham Biosciences). Protein products were analysed in $15 \%$ SDS-PAGE stained with Coomassie Blue R-250. For the quantification of the recombinant proteins, serial dilutions were compared in Coomassie stained gels with serial dilutions of known concentrations of BSA.

\subsection{Antibody production and Westem blotting}

Rabbit antisera were raised against LmEIF4Al-2, LmEIF4E1-2 and LmEIF4G326-310 by immunising adult New Zealand White rabbits with the His-tagged recombi- 
nant forms. For $L m E I F 4 E 3$, the GST-fusion was first cleaved with thrombin and the fragment corresponding to the protein excised from SDS-PAGE gels and used for the immunization. The various antibodies were affinity purified using the protocol described in [47], with minor modific ations, stored at $4^{\circ} \mathrm{C}$ with $0.03 \%$ sodium azide and used in a dilution of 1/500. Westem blots were performed with the ImmobilonP PVDF membrane (Millipore), using as second antibody peroxidase conjugated goat anti-rabbit IgG serum (Jackson ImmunoResearch Laboratories) diluted 1/15,000. The re actions were detected by enhanced chemiluminescence (ECL). Densitometric scanning of the various results was performed with the Kodak 1D Image Analysis Software, version 3.5 for Windows.

\subsection{Pull-down assays}

The Ni-NTA Agarose or glutathione-Sepharose beads used for the pull-down ass ays were initially equilibrated with binding buffer $\mathrm{B}$ ( $100 \mathrm{mM} \mathrm{KCl}, 1 \mathrm{mM} \mathrm{MgCl} 2,50 \mathrm{mM}$ Hepes $\mathrm{pH} 7.2,0.2 \%$ NP-40, $5 \%$ glycerol). Buffer B was supplemented with $5 \mathrm{mM}$ of imidazole during all the steps of the His-tagged pull-downs. For the GST-tagged protein experiments, the glutathione-Sepharose beads were initially saturated with $10 \mathrm{mg} / \mathrm{ml}$ of BSA, followed by two washes with Buffer B prior to their use in the assays. Approximately $10 \mu .1$ of the equilibrated beads was then incubated with $2 \mu \mathrm{g}$ of the His or GST tagged constructs in a final volume of $200 \mu \mathrm{L}$ (completed with Buffer B), for 1 hrotating at $4^{\circ} \mathrm{C}$. The beads were washed twice with Buffer $B$ and incubated with $10 \mu$, of translation lysate containing the ${ }^{35} \mathrm{~S}$-Met-labelled proteins, in Buffer B in a final volume of $200 \mu \mathrm{L}$, for $2 \mathrm{~h} \mathrm{at} 4^{\circ} \mathrm{C}$. After three more wa shes, the bound proteins were eluted by addition of SDS sample buffer and the samples ran on $15 \%$ SDS-PAGE.
The gels were stained with Coomassie Blue (to visualize the recombinant proteins), and subjected to autoradiography. Labelled proteins were obtained through the linearizations of the various plasmids described previously (with NotIfor pETLmEIF4GI $123-475$ and the LmEIF 4G3 variants and with XhoI for pET-LmEIF4G2337-705 and pRSET-LmEIF4A1-2), followed by transcription with T7 RNA polymerase in the presence of the cap analogue and translation in the rabbit reticulocyte lys ate supplemented with ${ }^{35} \mathrm{~S}$-methionine. To obtain the labelled human eIF4A, its cDNA in plasmid $\mathrm{pET}$ (HisseIF4A) [48] was first recovered by digestion with NdeI/NotI and subcloned into pET21A. The resulting plasmid was linearized with NotI and the eIF4A cDNA transcribed and translated as above. Labelled human eIF4G was obtained as described [49].

\section{Results}

3.1. Sequence analysis of four eIF $4 E$ homologues from L major

To characterise $L$ major $\mathrm{EF} 4 \mathrm{~F}$ homologues, we initially focused on four available eIF4E sequences which we named as LmEIF4E1 (GeneDB ID-LmjF27.1620), LmEIF4E2 (LmF19.1500/LmjF19.1480), LmEIF4E3 (LmjF28.2500) and LmEIF4E4 (LmjF30.0450) (see Table 1). Naming of the various proteins described in this word followed the proposed nomenclature for Leishmania and Trypanosoma proteins [50]. The potential eIF4E sequences code for proteins ranging in size from 214 to 281,349 and 447 amino acids, respectively, for $L m E I F 4 E 1-4$, with homologies vaying from 41 to $45 \%$ similarity to the human eIF4E homologue. Single genes present on chromosomes 27,28 and 30 encode

Table 1

Summry of the sequence anlysis of the various $L$. major eIF4F homologues, depicting identities (similarities) between the Leis/unania/muman sequences and between the L. major/T. brucei orthologues

\begin{tabular}{|c|c|c|c|c|c|}
\hline L major sequence & GeneDB ID & $\begin{array}{l}\text { Predicted molecular } \\
\text { weight }(k D a)\end{array}$ & $\begin{array}{l}\text { Chromosome } \\
\text { localization }\end{array}$ & $\begin{array}{l}\text { Identity (similarity) to } \\
\text { Human homologuen }\end{array}$ & $\begin{array}{l}\text { Identity (similnity) to the } \\
\text { T. bricei orthologue }\end{array}$ \\
\hline$L m E I F+E I^{b}$ & LmjF27.1620 & 24 & 27 & $22 \%(42)$ & $48 \%(61)$ \\
\hline$L m E I F+E 2 b$ & LmjF19.1500/LmjF 19.1480 & 31.5 & 19 (2 genes) & $27 \%(41)$ & $45 \%(57)$ \\
\hline LMEIF4E3 & LmjF28.2500 & 38 & 28 & $27 \%(43)$ & $49 \%(61)$ \\
\hline LmEIF4E4 & $\operatorname{LmjF} 30.0450^{c}$ & 33.8 & 30 & $28 \%(45)$ & $37 \%(50)$ \\
\hline$L m E I F+A l^{b}$ & LmjF01.07 $00 / \mathrm{LmjF}$ O1 0770 & 45.3 & 1 (2 genes) & $56 \%(74)$ & $85 \%(91)$ \\
\hline$L m E I F+A 2$ & LmjF28.1530 & 43.9 & 28 & $50 \%(71)$ & $79 \%(89)$ \\
\hline LmDHHl & LmjF 35.0370 & 46.4 & 35 & $30 \%(50)$ & $86 \%(92)$ \\
\hline LmEIF4GI & LmjF15.0060 & 114 & 15 & $25 \%(43)^{d}$ & $31 \%(47)$ \\
\hline$L m E I F+G 2$ & LmjF15.1320 & 145.9 & 15 & $21 \%(37)^{d}$ & $33 \%(49)$ \\
\hline LmEIF4G3 & LmjFl6.1600 & 71.2 & 16 & $26 \%(39)^{d}$ & $38 \%(55)$ \\
\hline LmEIF4G4 & LmjF36.6060 & 84.6 & 36 & $22 \%(38)^{d}$ & $26 \%(+5)$ \\
\hline LMEIF+G5 & LmjF10.1090 & 88.8 & 10 & $21 \%(37)^{d}$ & $43 \%(60)$ \\
\hline
\end{tabular}

Recults obtined wing the GenB ank BLAS T with the BLOSUM 62 Matrix.

${ }^{2}$ Humn eIF+GI. GenB.ank accession: Q04637.

b GenBank accescion avilable: LmEIF4E1-CAB77676; LmEIF4E2-CAB94109 and CAB94111; LmEIF4A1-NP.047099.

' Here the sequence ured in our andysic includes the N-terminl extension, present in the $T$. bricei orthologue, which has been omitted from the $L$ major GeneDB annotation.

d These seguences show similarity to the humn sequence only at the level of the central HEAT domin. 
$L m E I F 4 E 1,3$ and 4, respectively. In contrast, $L m E I F 4 E 2$ is encoded by two identical genes contained within a small duplicated region on chromosome 19, which also includes an unidentified trans-membrane protein $\mathrm{ORF}$, separated by approximately $4.5 \mathrm{~kb}$.

In order to compare conserved features in the four Leishmania eIF4E homologues we aligned these sequences with characterised human, yeast and plant eIF4E proteins (Fig. 1). Two distinct Caenorhabditis elegans homologues with contrasting cap binding affinities - IFE- 1 which binds both monomethylated and trimethylated caps and IFE-3 which only binds a monomethylated cap [51] - were also included in the alignment. For simplicity, all the numbers mentioned in Fig. 1 will refer to the amino acids' position in the human eIF4E sequence which is representative of the mammalian protein (only three substitutions in the $\mathrm{N}$-terminus distinguish the human and mouse sequences). eIF4E is characterised by eight tryptophan residues located at conserved positions along the protein $[41,12]$. LmEIF4E2 contains all eight of these tryptophan residues, $L m E I F 4 E 1$ contains seven, $L m E I F 4 E 4$ five and $L m E I F 4 E 3$ only four. Three-dimensional structures of mouse eIF4E and its yeast homologue, both bound to 7-methyl-GDP, were solved by $\mathrm{X}$-ray crystallography [41], and by solution NMR spectroscopy [52], respectively. The complex is shaped like a cupped hand, with the cap analogue located in a narrow capbinding slot on the concave side of the protein. Recognition of the 7-methylguanine moiety is mediated by base sandwichstacking between W56 and W102, formation of three Wats onCrick-like hydrogen bonds with a side-chain carboxylate of a conserved E103 and a backbone NH of W102, and a van der Waals contact of the N(7)-methyl group with W166. The four residues making contacts with 7-methylguanine are conserved among most known eIF4E proteins (see Ref. [41] and Fig. 1). All four are present in both LmEIF4E1 and LmEIF4E2, while in $L m E I F 4 E 3-4$ W56 is replaced by a methionine and a glutamate, respectively. Of the three residues that interact with the two phosphate groups, R157 is absolutely conserved in $\mathrm{eIF} 4 \mathrm{E}$ sequences, and the remining two residues (R112 and K162) make either direct or water mediated contacts with phosphates and are either arginine or lysine [41]. In the Leishmania proteins, LmEIF4E1 and 2 contain $\mathrm{K} 112, \mathrm{R} 157$ and $\mathrm{R} / \mathrm{K} 162$, respectively, while both $L m E I F 4 E 3-4$ contain only R157, and lack basic residues at 112 and 162. On this basis, LmEIF4E1 and 2 possess all the features expected of a 7-methyl-GDP-binding protein, while LmEIF4E3-4 have some, but not all, the predicted features.

eIF4G binds the convex dorsal side of eIF4E primurily due to the interaction between W73 of eIF4E and three amino acid side chains of the eIF4E binding peptide, YXXXXI phi (where $\mathrm{X}$ can be any amino acid and phi is usually a hydrophobic amino acid such as $L, M$ or F [23]), also present in eIF4E-binding proteins $[53,54]$. Mutation of W73 to A or R, respectively, in the mouse and yeast eIF4Es abolishes binding to eIF4G, while the yeast F73 eIF4E mutant maintains binding to $\mathrm{eIF} 4 \mathrm{G}[55,31]$. LmEIF4E2, 3 and 4 contain W73, while LmEIF4El contains F73 (Fig. 1); thus on this basis all four proteins would be predicted to be able to interact with eIF4G.

The most striking differences between the Leishmania proteins and known eIF4Es include the LmEIF4E3-4 Nterminal extensions of about 80 and 190 amino acids, respectively, a shorter C-terminus for $L m E I F 4 E 1$ and the significant insertions of variable number of amino acids at specific positions in the first three Leishmania proteins. LmEIF4E1 is distinguished by the presence of a 21 amino acids long insertion not observed in other eIF4E sequences. LmEIF4E2 has two short insertions, one of them also present in LmEIF4E3, which are located next to amino acids relevant to cap binding, and a third long insertion on its C-terminus. Comparison with the two nematode eIF4E sequences included in Fig. 1 does not indicate any motifs that may be involved in differential cap recognition and indeed it seems that the multiple eIF4E homologues evolved independently in both systems. Nevertheless, a comparison between the L. major and $T$. bricei eIF4E sequences (Table 1; see Section 4) confirm that all the specific features mentioned above for the various $L$. major proteins, with minor variations, are also conserved in the four T. bricei homologues. Such conservation indicates that the multiple eIF4E proteins are conserved within the family Trypanosomatidae and play signific ant roles during the parasites' life cycle.

\subsection{Expression analysis and quantitation of LmEIF 4EI-3 in L. major promastigotes}

LmEIF4E1-3 (LmEIF4E4 was only identified later in this study) were expressed in E. coli His-tagged or as GST-fusions and isoform-specific antibodies generated in rabbit against the three proteins. These antibodies were affinity purified and tested in Western blots against the recombinant GST fusions to confirm their specificity. No cross-reaction was observed to the other recombinant $L$. major eIF4Es (data not shown). They were then used to analyse the expression and to estimate the cellular levels of LmEIF4El-3 in extracts of exponentially growing $L$. major promastigotes (Fig. 2). All three proteins were detected in these extracts although their levels varied significantly, with $L m E I F 4 E 3$ being very abundant $\left(>5 \times 10^{4}\right.$ molecules/cell $)$ and both $L m E I F 4 E 1$ and 2 present at much lower levels (about $2-4 \times 10^{3}$ and $10^{3}$ molecules/cell, respectively-Table 2 ). When compared to yeast eIF4E $\left(3.2-3.6 \times 10^{5}\right.$ molecules/cell [56]), even LmeIF4E3 is expressed at levels lower than those obtained for the yeast protein. However, considering that in yeast, a significant fraction of the eIF4E pool is not complexed to eIF4G (present at only $(1.5-2) \times 10^{4}$ molecules/cell) these levels could acc ount for the production of enough eIF4F for the survival of the organism. Nevertheless it seems unlikely that the levels of either $L m E I F 4 E 1$ or $L m E I F 4 E 2$ alone would be sufficient to suppoit translation in the se parasites, at least in the promastigote stage. 

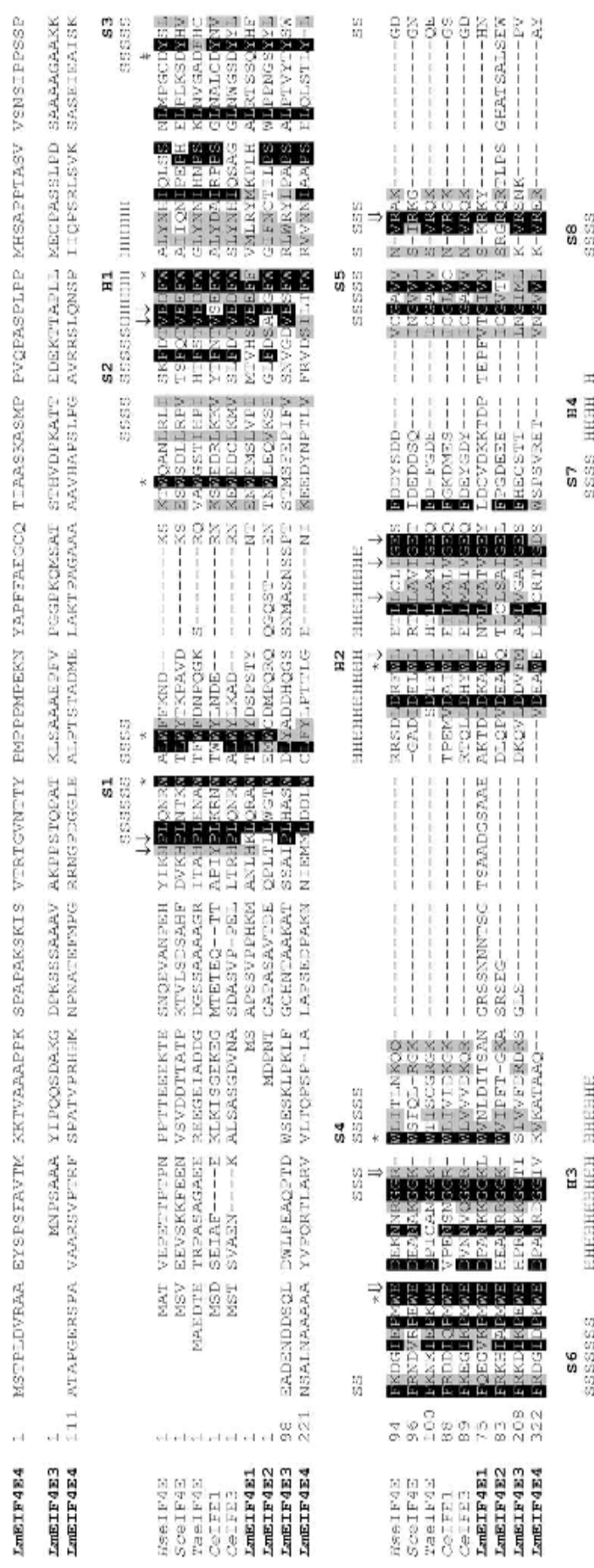

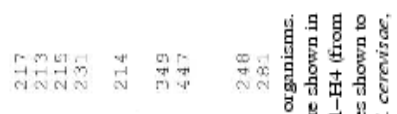

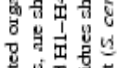

管

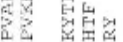

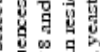

손

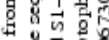

4

$\begin{array}{ll}0 & 3 \\ 0 & 0 \\ 0 & 0\end{array}$

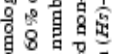

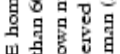

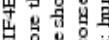

1tion of

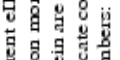

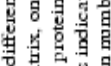

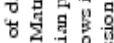

म

x

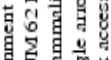

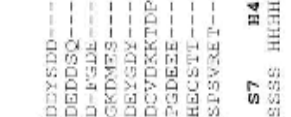

3.

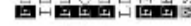

is
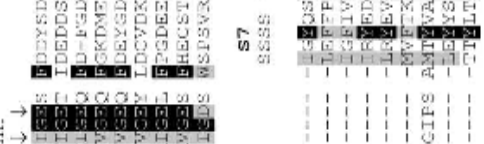

$-1+1+1,1+1$

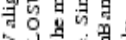

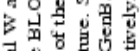

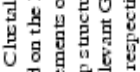

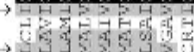

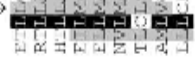

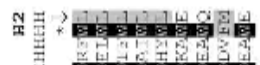

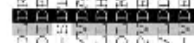

至

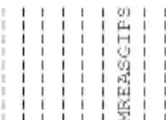

筞

s.

8

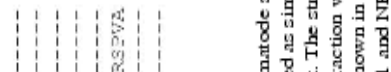

尊薄尊

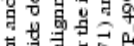

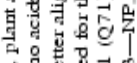

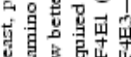

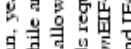

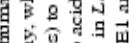

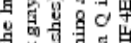

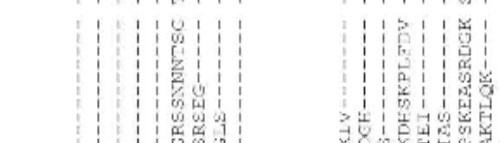

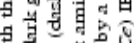

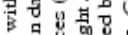

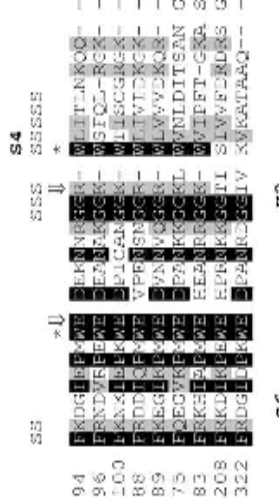

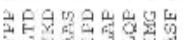

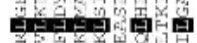

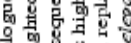

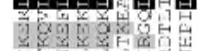

盟臂

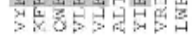

anong

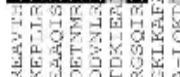

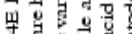

岁

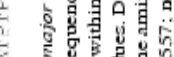

is

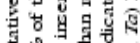

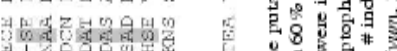

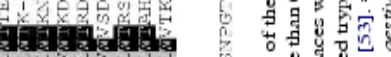

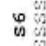

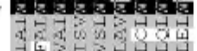

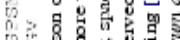

等

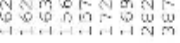

त)

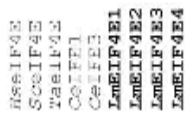

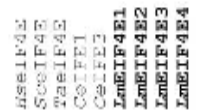

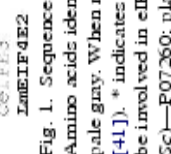




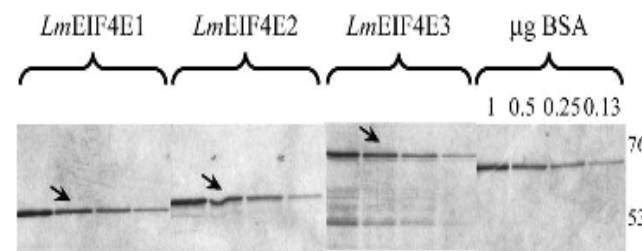

(A)

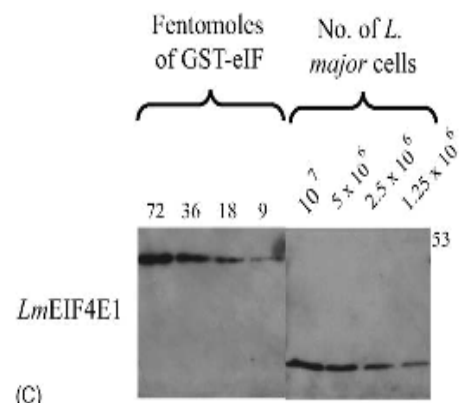

(C)

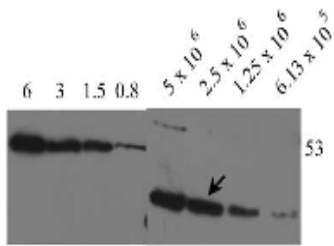

LmEIF4E2

$\begin{array}{llll}174 & 87 \quad 44 \quad 22\end{array}$

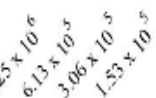

LmEIF4E3

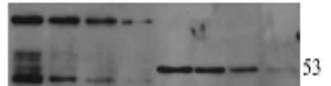

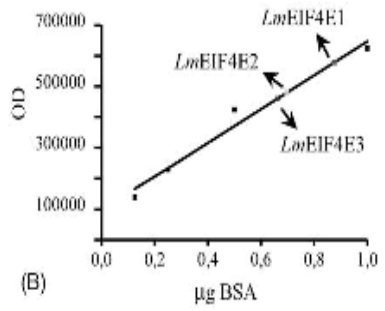

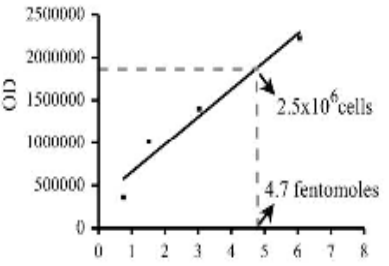

(D)

fentomoles LmEIF4E2

Fig. 2. Expression amlysis and quantitation of $L m E I F 4 E 1-3$ in exponentially grown $L$. major prometigotes. (A) Serial dilutions of recombinant GS T-tagged LmEIF4E1-3 compred in Coomascie Blue stained gels with known concentrations of BSA. (B) Quntitation of the recombinnt proteins (a representative example is shown). The bande from the BSA curve shown in A were quantified by densitometric $x$ anning and plotted as a function of the BS A concentuation. To calculate the concentration of recombinant $L m E I F 4 E 1-3$, the optical density of representative bund from these proteins (indicated by arrows in the figure) was determined to denive approximnte quantities using the BSA curve. (C) Expression analysis of $L m E I F+E 1-3$ in extract of $L$ major promrstigotes. The different recombinunt GST-fusions, diluted to appropiante concentrations (in fentomoles), and whole pansite extracte were fnctionnted by 15\% SDS-PAGE and analyeed by western blotting with the iroform specific sera. (D) Procecture for the quantitation of the endogenous levele of the variou factors using LmEIF4E2 as an ex.ample. The Westem blot recult shown in C for GST-LmEIF4E2 was quantitated by dencitometry and plotted $x$ a function of fentomoles of recombinant protein. The optical density obtrined for the endo genous factor at $2.5 \times 10^{6}$ cells (arrow) was then used to calculate it concentration in fentomoles (4.7 fentomoles in the example). The same procedure wax ured for the different factore including LmEIF4Al and LmEIFHG3. All the result presented are representative of at lenst six different experiments using a minimum of three independently grown cell cultures. The data obtained from the various experimente were processed as described above and used to calculate the values shown in Table 2 . On the right of the variour panels in $A$ and $C$ are shown the sizes in $k D a$ of protein molecular weight malkes.

\subsection{Cap binding assay of the putative LmEIF4Es}

LmEIF4E1-3 were then labelled with ${ }^{35}$ S-Met by in vitro translation and te sted for their ability to recognise the mammalian monomethylated cap. As a positive control, Xenopus eIF4E was also labelled and used in the same assay. All four proteins were tested in binding assays with the resin
7-methyl-GTP Sepharose 4B, followed by washes with GTP and elution with the cap analogue. The Xenopus eIF4E bound to the resin as expected, and was eluted with the cap analogue. In contrast, of the three $L$. major proteins, only $L m E I F 4 E 1$ was capable of binding to the resin (Fig. 3). Binding was specific since GTP did not rele ase the protein and in parallel experiments performed with CL6B Sepharose no bind- 
Table 2

Summury of the quantitation of the variou $L$. major eIF $4 \mathrm{~F}$ homolo gues in promstigotes

\begin{tabular}{llll}
\hline L major sequence & Fentomoles/10 cell & No. of molecules/cell & No. of molecules/cell in yeast \\
\hline LmEIF4E1 & $5.2 \pm 2.5$ & $3.2 \pm 1.5 \times 10^{3}$ & $(3.2-3.6) \times 10^{5}$ \\
LmEIF4E2 & $1.8 \pm 0.5$ & $1 \pm 0.3 \times 10^{3}$ & \\
LmEIF4E3 & $117 \pm 56$ & $7.1 \pm 3.4 \times 10^{4}$ & $(7-9) \times 10^{5}$ \\
LmEIF4A1 & $594 \pm 218$ & $3.6 \pm 1.3 \times 10^{5}$ & \\
LmEIF4A2 & ND & ND & $(1.5-2) \times 10^{4}$ \\
LmEIF4G3 & $10.6 \pm 4.1$ & $6.4 \pm 2.5 \times 10^{3}$ & \\
\hline
\end{tabular}

${ }^{a}$ Numbers based on Ref. [56] for yenst eIF4E, eIF4A and eIF4G. ND: not detemined.

ing was observed (not shown). LmEIF4E2 and 3 lacked any affinity with the resin, both labelled proteins eluted in the flow-through. These results confirm that at least one of the Leishmania putative eIF4E homologues ( $L m E I F 4 E 1)$ has all the hallmarks of a typical eIF4E, including size, sequence and cap-binding ability.

\subsection{Modelling of LmEIF 4EI}

In order to better define the structure/function conservation of the three L. major eIF4E homologues (LmEIF4E1-3), we attempted to model their structure based on the mammalian eIF4E structure [41]. However, adequate modelling of both $L m E I F 4 E 2$ and $L m E I F 4 E 3$ was prevented due to the insertions between the first two $\beta$-strands ( $\mathrm{S} 1$ and $\mathrm{S} 2$ in Fig. 1) which are essential to define the cap-binding slot. In contrast, the 21 amino acids long insertion in LmEIF4E1, which is located in a loop between a $\beta$-strand and an $\alpha$-helix (S4 and $\mathrm{H} 2$ ), did not prevent its modelling since it does not c ause major interferences with the $\beta$-sheet or the general structure. In addition to the MODELLER pseudo-energy term, the quality of the models generated for $L m E I F 4 E 1$ was also independently evaluated by the programs PROCHECK, Verify 3D and WHATIF [43-45]. The representative model chosen was found to have self-consistency in terms of sequence- structure compatibility and to be of good overall quality (Fig. 4).

The final LmEIF4E1 model confirms the predictions derived from the alignment in that it is possible to observe that the interactions mediated by the amino acids W56, D 90 , W102, E103, R157, K162, R112 and W166 in mammalian eIF4E, which are required for specific binding to the 7methyl-GDP, are taken over by the amino acids W37, Q71, W83, E84, K93, R167, R172 and W176 (Fig. 4B). The potential to bind eIF4G was also investigated through the analysis of the convex side of the molecule. The amino acid F54, replacing the crucial W73 in mammalian eIF4E, is placed in the expected position for the eIF4E/eIF4G interaction (Fig. 4C). Also shown in Fig, 4C are the amino acids H20 and V50 equivalent to $\mathrm{H} 37$ and V69 in the mammalian protein, as well as amino acids E134 and M138 substituting for L128 and L135 (Fig. 1). In mammalian eIF4E, these amino acids have been shown to be involved in the eIF4E/eIF4G interaction [53]. Their positioning in the LmEIF4E1 model confirms that, despite the minor variations in sequence, not only $L m E I F 4 E 1$ but the other $L$ major IF $4 E$ homologues to 0 may bind eIF4G. Finally, an analysis of the electrostatic potential of both the cap binding slot as well as the EIF4G binding side in the LmEIF4El model, using the program GRASP [57], does not show any signific ant differences in overall charges

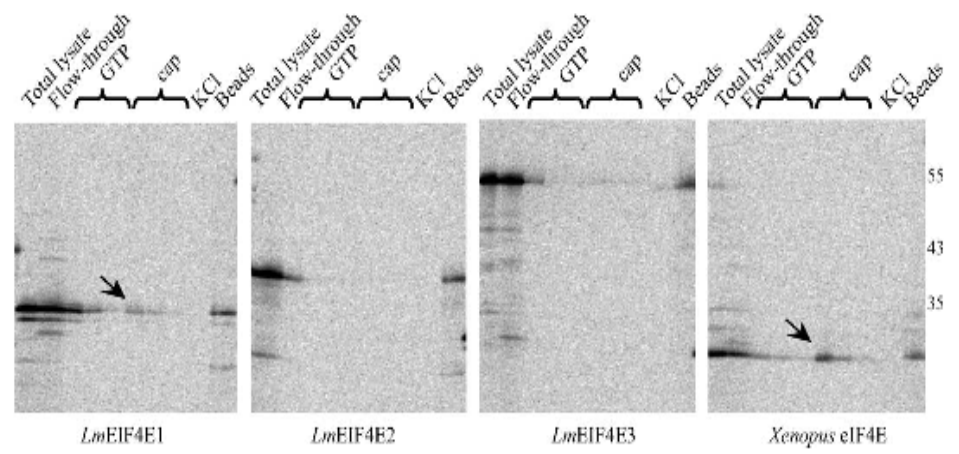

Fig. 3. $L m E I F 4 E 1$, but not $L m E I F 4 E 2$ or 3, binde specifically to the eularyotic cap analogue. The three $L$ major eIF4E homolo gues ( $L m E I F 4 E 1-3)$, as well as the $\mathrm{X}$ laevis $\mathrm{eFF} 4 \mathrm{E}$ (Xenopus in the figure) used as positive control, were labelled with ${ }^{35} \mathrm{~S}$-methionine by in vitro translation and tested for their ability to bind the resin 7-methyl-GTP Sepharoce. Non-specific binding was removed by washes with GIP and specific elution was achieved with the cap analogue. Aliquots of the various usches were rn on SDS-PAGE and compured with samples from the original traxelation reaction (Total lysate) as well as the non-bound fraction (Flow-through) and any protein remaining bound to the beads after washes with $2 \mathrm{M} \mathrm{KCl}$ and SDS-PAGE sumple buffer (Bends). Arows indicante proteire eluted by cap analogue. On the right are indicated sizes in $k D$ a of protein molecular weight markers. 


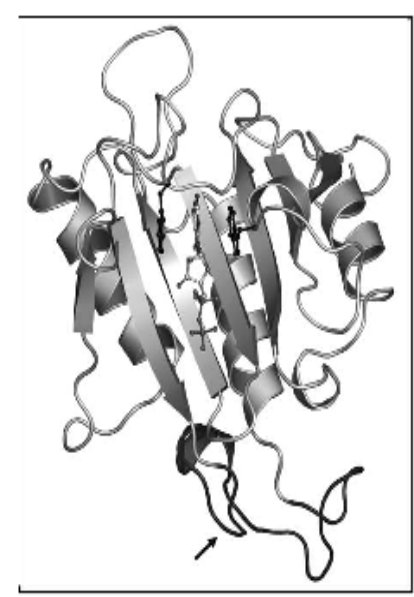

(A)
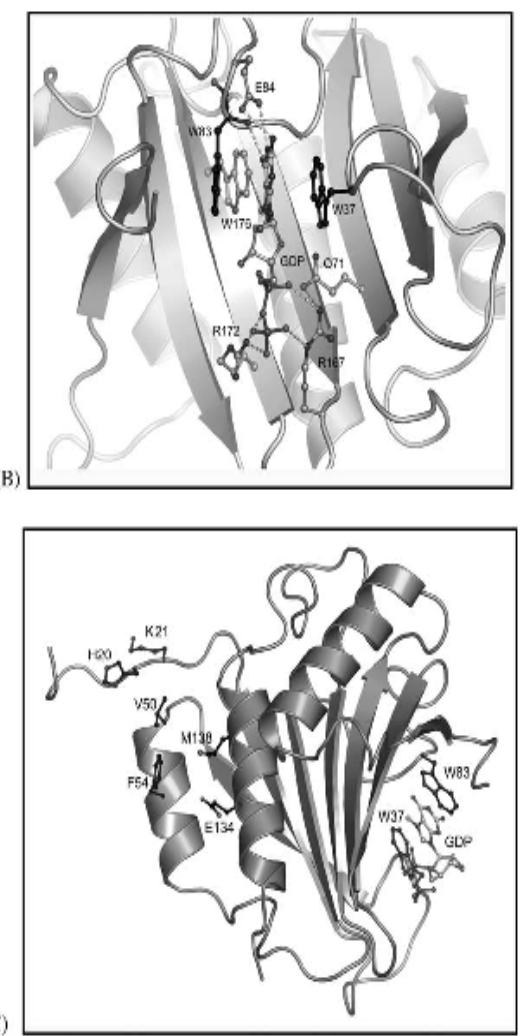

Fig. 4. Model of the predicted LmEIF4E1 structure bound to 7-methyl GDP. Ribbon dingrame of the overall predicted LmEIF4El structure and detril of the cap binding slot created using the program PyMol (http://www.pymolorg). (A) Model of the structure of LmEIF4E1 bound to 7-methyl GDP, based on the moxe eIF4E structure [41]. W37 and W83 (equivalent to W56 and W102 in mmmalinn eIF4E) are shown binding the cap. The arrow indicates the lopp specific to LmEIF4E1 which could not be modelled adequately. (B) The cap bindings lot in the predicted structure, highlighting the intenctions between amino acids W37, 071. W83, E84, R167, R172 and W176 and the cap nucleotide. The intenction mediated through water molecules are not shown 50 that the K93 interaction (corresponding to $\mathrm{R} 112$ in mammls) is omitted. (C) Side view of the LmEIF+EI model showing detrilt of the predicted eIF4G binding surface. Amino acide $\mathrm{H} 20$, K21, V50, F54, E134 and M1 38 equivalent to H37, P38, V69, W73, L128 and L1 135 in the mammlinn protein are highlighted. The cap binding slot with the W37 and W83 amino acids is aloo shown.

when compared with the mouse homologue (not shown). Once again these results confirm that $L m E I F 4 E 1$ has all the features required for a functional eIF4E homologue.

\subsection{Sequence analysis of the two L. major EIF4A proteins}

The RNA helicase subunit of the eIF4F complex, eIF4A, is a highly conserved eukaryote protein. The similarity between the described $L$. major eIF4A (LeiF) [36] here called LmEIF4A1, and the human eIF4A1 homologue is $74 \%$ (Table 1). LmEIF4Al (GeneDB IDs-LmjF01.0780/LmjF01.0770) is a 403 amino acids long protein encoded by two identical genes placed in tandem roughly $1.8 \mathrm{~kb}$ apart within chromosome 1 (Table 1). Blast searches with the human eIF4A as query using the raw sequence data from the $L$. major genome yielded both
LmEIF4A1 as well as a possible second eIF4A homologue from L. major (LmEIF4A2-LmjF28.1530), with 71\% similarity to the human protein. The LmEIF4A2 gene is located on chromosome 28 and codes for a 389 amino acids long protein. Orthologues to both Leishmania eIF4A proteins were also identified in $T$. brucei, indicating that they are conserved within the Trypanosomatids (Table 1).

Fig. 5 shows a sequence alignment comparing both $L$. major eIF4A sequences with those of human, yeast and plant eIF4A homologues. We have also included in the alignment human eIF4AIII (a negative regulator of translation [58]), a related Eubacteria protein ( $E c W 2)$ which may also be involved in translation initiation [59], an Archae DEAD-box protein (MJDEAD) whose structure has been solved [60], as well as two unrelated eukaryotic RNA helicases, $L m D H H l$ and Spisula p47 (see below). eIF4A and other related DEADbox RNA helicases are characterised by nine motifs (motifs I, 


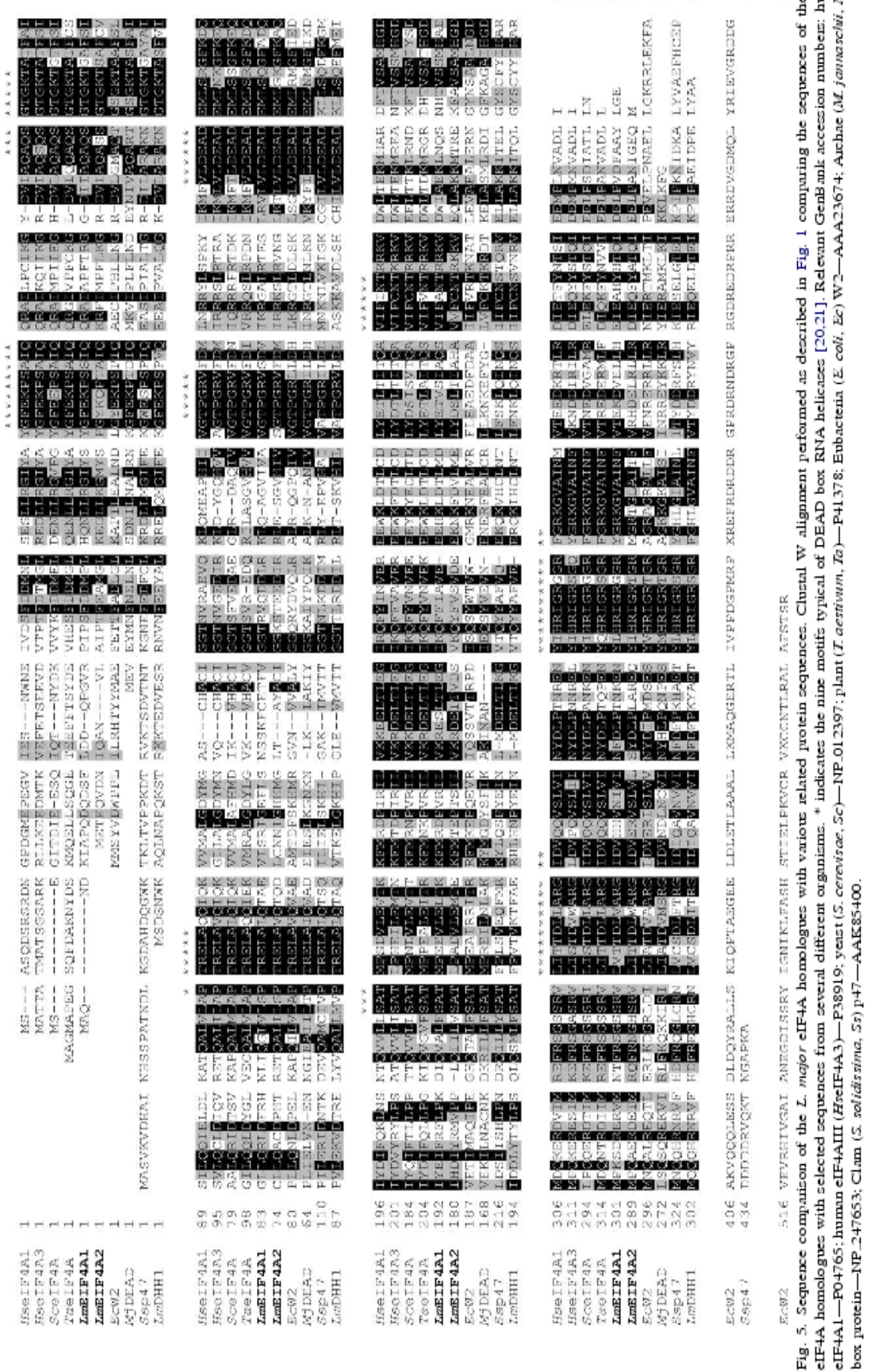


Ia, Ib, II, III, IV, V and VI plus the recently identified Q motif), conserved among the various members of this protein family, with roles in ATP binding, and hydrolysis, and RNA-binding $[61,20]$. The crystal structure of ye ast eIF4A [62] indicates that it assumes a "dumbbell" shape with two globular domains connected by a flexible linker and it implicates several conserved arginine residues as important for eIF4A/helic ase function. It is thought that these domins interact so that the binding and hydrolysis of ATP influences RNA binding, and comparison with the structure of the related protein from the Archae Methanococcus jannaschii MJDEAD supports this model $[60,21]$.

Overall, the alignment in Fig. 5 indic ates that both $L$. major proteins share all the conserved motifs from RNA helicases, as well as several minor sequences typical of eIF4A. To support our identification of $L m E I F 4 A 1$ and 2 as possible eIF4A homologues, we searched the $L$ major sequence databases for any related RNA helic ases. The sequence with the nearest match ( $\mathrm{LmDHH} l$ in Fig. 5) contains all the motifs which characterise the DEAD-box RNA helicases yet it shares a similarity of only $50 \%$ with the human eIF4A1 sequence (Table 1). Remarkably this protein has a much higher degree of similarity $(82 \%)$ to the clam Spisula solidissima p47 RNA helicase [63], a member of the Dhh1/p54 family of RNA helicases, with roles in decapping and translational repression $[63,64]$, suggesting that it is a Dhhl homologue. The sequences aligned in Fig. 5, plus a few others which we judged relevant, were used in a neighbour-joining analysis to compare their phylogenetic relationships. The resulting tree (Fig. 6A) confirms that both $L$ major $\mathrm{IF} 4 \mathrm{~A}$ homologues are more closely related to each other and to other eIF4A proteins involved in translation than to unrelated RNA helicases including $\mathrm{LmDHHl}$ and bacterial proteins, and also highlights the close

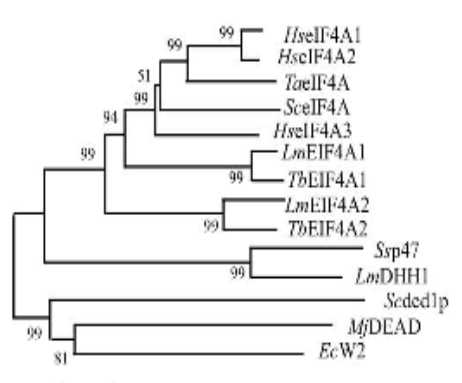

(A) $\stackrel{b .1}{\longmapsto}$

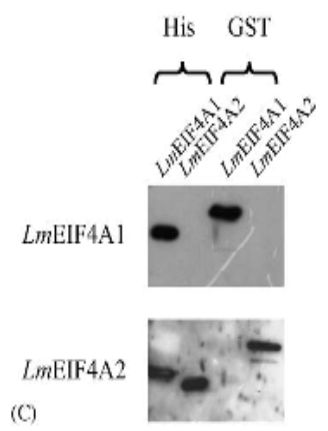

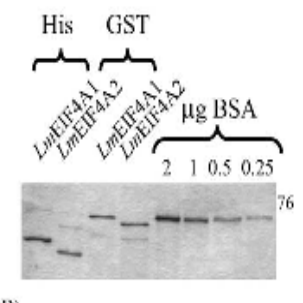

(B)

Fentomoles No. of $L$. of GST-eIF major cells

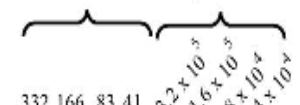

$33216683413^{2^{+}} 6^{+} 8^{+}+x^{+}$

LmEIF4A I
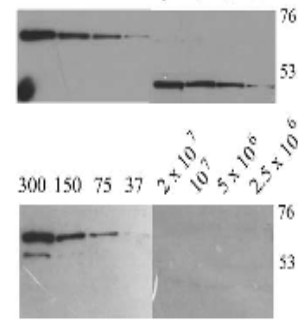

Fig. 6. $L m E I F 4 A 1$, but not $L m E I F 4 A 2$, is expresced as an abundunt protein in $L$. major promastigotes. (A) Evolutionuy relationship of the $L$ major eIF 4 A sequences. Neighbour-joining tree bxed on the alignment of various eIF 4 A sequences including LmEIF $4 A 1-2$. Boctrap values are shown next to the respective branches (10,000 replicates). When compred with Fig. 5 we hnve included for this tree the sequence from: human eIF4A2 (GenB ank accession AAH1 2547); S. cerevisae dedlp (accescion-NP.014847); T. bnice elF4Al (GeneDB DD-Tb09.160.3270); T. bncei eIF4A2 (GeneDB ID-Tb11.12.0011). (B)-(D) Expression analysis of the two putative $L$ major eIF4As done as dexribed in Fig. 2 wing recombinant $L m E I F+A 1-2 x$ well as isoform specific purified antibodies. (B) Recombinunt proteirs uxed for antibody production (His) and qunntitation assays (GST). Approximately 0.5 (His-LmEIF4A2 and both GST proteins) or $1 \mu \mathrm{g}$ (His-LmEIF4Al) of each recombinant protein was loaded on the gels and compared with known concentrations of BSA. (C) Analyzis of the specificity of the antibody obtuined against the recombinant proteirs. Both GST and His-trgged fusions of LmEIF +Al-2 were tected with the two antisera. For the $L m E I F+A 1$ ascay, $12.5 \mathrm{ng}$ of each recombinant protein were loaded on the gel whilt for $L m E I F 4 A 26.25 \mathrm{ng}$ of the His and $25 \mathrm{ng}$ of the GST fusion were used. Note that the antibody produced against Hir-LmEIF4A2 crose-rencte with His-LmEIF4A1 since both recombi munt proteins shue conserved epitopes introduced by the phemid vector. These epitopes ae abcent from the GST corrtucts and from the protein used to produce the anti- $L m E I F+A \mid$ antibody. (D) Amlysis of the expression of both $L m E I F 4 A 1$ and $L m E I F 4 A 2$ in total $L$ major extanct. Quntitation of $L m E I F 4 A 1$ in promastigotes wx performed as described for the $L m E I F+E$ homologues in Fig. 2. 
conservation between the Leishmania and T. brucei orthologues.

\subsection{LMEIF4As quantitation and expression analysis in \\ L. major}

Both the $L m E I F 4 A 1$ and the $L m E I F 4 A 2$ coding sequences were amplified from $L$. major genomic DNA, expressed in E. coli and purified in His- or GST-tagged forms. Fig. 6B shows a sample of the representative recombinant proteins. His-tagged $L m E I F 4 A 1$ and 2 were then used to immunize rabbits to obtain specific antisera. The resulting antibodies were affinity purified and used to confirm their specificity as well as to determine their cellular levels in total $L$. major extracts as described for the LmEIF4Es (Fig. 6C and D). LmEIF4A1, readily detected in promastigotes, is a very abundant protein with about (3-5) $\times 10^{5}$ molecules per cell (Fig. 6D, Table 2). This concentration is not very different from that of yeast eIF4A [56], and the eIF4A/eIF4E ratio in ye ast is similar to that of LmeIF4A1/LmEIF4E3. These values are also consistent with results in HeLa and reticulocyte lysate where eIF4A has been found to be a very abundant translation initiation factor present at levels approximately 10 -fold higher than eIF4E $[65,66]$. In contrast we could not detect $L m E I F 4 A 2$, even in $2 \times 10^{7}$ promastigote cells (Fig. 6D). We estimate from the sensitivity of the LmEIF4A2 antibody that levels above $3 \times 10^{3}$ molecules/cell would have been detected. However in this case, its a bund ance would be at le ast 60-150-fold lower than that of $L m E I F 4 A 1$. We conclude then that $L m E I F 4 A 1$ is the functional homologue of eIF4A in $L$ major promastigotes and that $L m E I F 4 A 2$ is either expressed in other stages of the parasite life cycle, or is a rare factor which is unlikely to have a prominent role in general translation

\subsection{Identification of candidate LmEIF 4G homologues}

In contrast to eIF4A, the eIF4G subunit of eIF4F is a much less conserved protein at the sequence level. The two functionally equivalent eIF4G homologues in mammals (eIF4GI and II) and in yeast (Tif4631 and Tif4632) are only $\sim 45 \%$ identical. However, the central eIF4A/RNA binding domain is conserved in the eIF4G sequences from divergent organisms (reviewed in [12]). The recently solved structure of this domain from human EIF4GII consists mostly of alpha-helices organised into HEAT repeats [26]. The EIF4G HEAT domain not only mediates the interaction with eIF4A and RNA [26], but in yeast was also implicated, together with flanking sequences, in the binding to eIF5 and eIFl to bridge the interaction between eIF3 and eIF4G [67,68]. A second motif conserved in eIF4G sequences from distantly related organisms is the eIF4E binding peptide [23], whilst the PABP binding region does not appear to be conserved in sequence from ye ast to mammals $[69,25]$.

Using the human eIF4GI as a BLAST query, we found five $L$. major ORFs containing the conserved central eIF4G domain (LmEIF4G1, GeneDB ID-LmjF15.0060;
LmEIF4G2-LmjF15.1320; LmEIF4G3-LmjF16.1600; LmEIF4G4-LmjF36.6060; LmEIF4G5-LmjF10.1080). The five proteins vary significantly in size (ranging from 1016 to $1425,635,765$ and 782 amino acids for LmEIF4G15 , respectively), overall charge (positive in $L m I \mathbb{E F} 4 \mathrm{Gl}$ and negative in the other four) and in the relative location of the conserved eIF4G domain (central in LmEIF4G1, 2, 5 and N-terminal in LmEIF4G3-4). Both the LmEIF4G1 and LmEIF4G2 genes are located on chromosome 15 while the LmEIF4G3-5 genes lie on chromosomes 16, 36 and 10, respectively (see Table 1). No additional similarities with human, yeast or plant homologues can be seen within their sequences and surprisingly, no obvious EIF3, eIF4E or PABP binding domains can be identified based on homology analysis alone (not shown, see Section 4). Apart from the HEAT domain, the Leishmania sequences appear unrelated, with the exception of LmEIF4G3 and 4. These two proteins share a short similar $\mathrm{N}$-terminus and a conserved region (approximately 120 amino acids long) located about 180 amino acids downstream of the HEAT domain, indicating that they may be functionally related.

Fig. 7 shows an alignment comparing the sequences of the HEAT domain from the five putative L. major $\mathrm{IF} 4 \mathrm{G}$ proteins with the equivalent sequence from humn eIF4GI, $S$. cerevisae Tif4631p, and whe at eIFiso $4 \mathrm{G}$ as well as the translation regulator PAIP1. Overall, the domain from LmEIF4G1 is the most similar to human eIF4G whilst the ones from LmEIF4G2 and 5 are the least similar (Table 1), but the differences are small. All five $L$ major domains contain most of the conserved amino acids which in mammalian eIF4G homologues are required for binding to eIF4A $[29,30,26]$. Residues which have been shown not to be required for eIF4A binding (such as F737, K765, E769, P770, F812 and R855-human eIF4GI numbering) are als o well conserved in most Leishmania proteins and presumably have other conserved functions. It may be noteworthy that the doublet E769/P770 (strictly conserved in LmEIF4G1, 3 and 4) has been implicated in $43 \mathrm{~S}$ recruitment and formation of the 48S complex [26]. Nevertheless, it is not possible to identify which of these proteins are true eIF4G orthologues with major roles in translation initiation. Strikingly, orthologues to all five proteins, with significant conservation outside the HEAT domain, have been identified in both $T$. brucei (Table 1 ) and in $T$. cruzi (data not shown) confirming their importance for the survival of these organisms as a group.

3.8. Analysis of the interaction between L. major eIF4A/eIF4G through pull-down assays

In animals, yeast and plants, the specific binding between the eIF4A and eIF4G subunits of eIF4F needs to occur so that both proteins can function in translation. In order to functionally demonstrate a possible role in translation for the various $L$. major candidate eIF4A/eIF4G proteins, we investigated their interaction through pull-down assays. First, to validate the assay, we immobilised $\mathrm{N}$-terminally His-tagged 

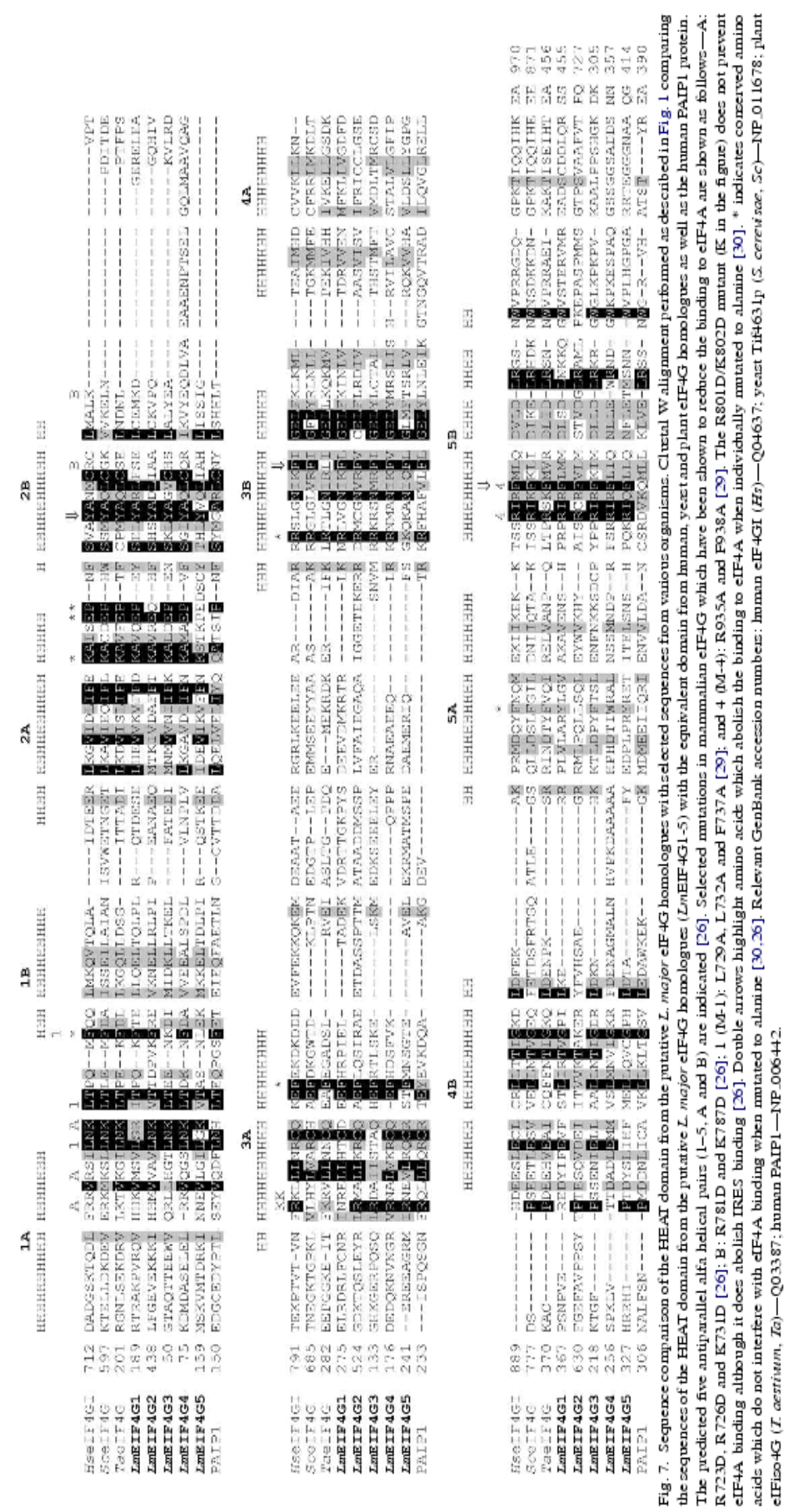
recombinant $L m$ EIF4A1-2 and human eIF4A (His6-eIF4A [48]) on Ni-NTA beads (Fig. 8A-left panel), and incubated the beads with ${ }^{35}$ S-labelled human eIF4G [70]. Human eIF4A efficiently bound to human eIF4G, however neither LmEIFA1 nor LmEIFA2 was capable of binding to the human protein (Fig. 8A-right panel). Next, fragments cod- ing for the HEAT domain from three of the $L$. major candi-

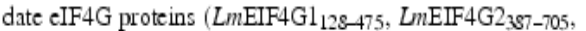
$L m E I F 4 G_{3} 26-310$ ), were synthesised in the presence of ${ }^{35} \mathrm{~S}$ methionine and assayed for their ability to bind eIF4A. All three fragments include the region equivalent to amino acids $722-949$ from human eIF4G1 sufficient to promote 48S
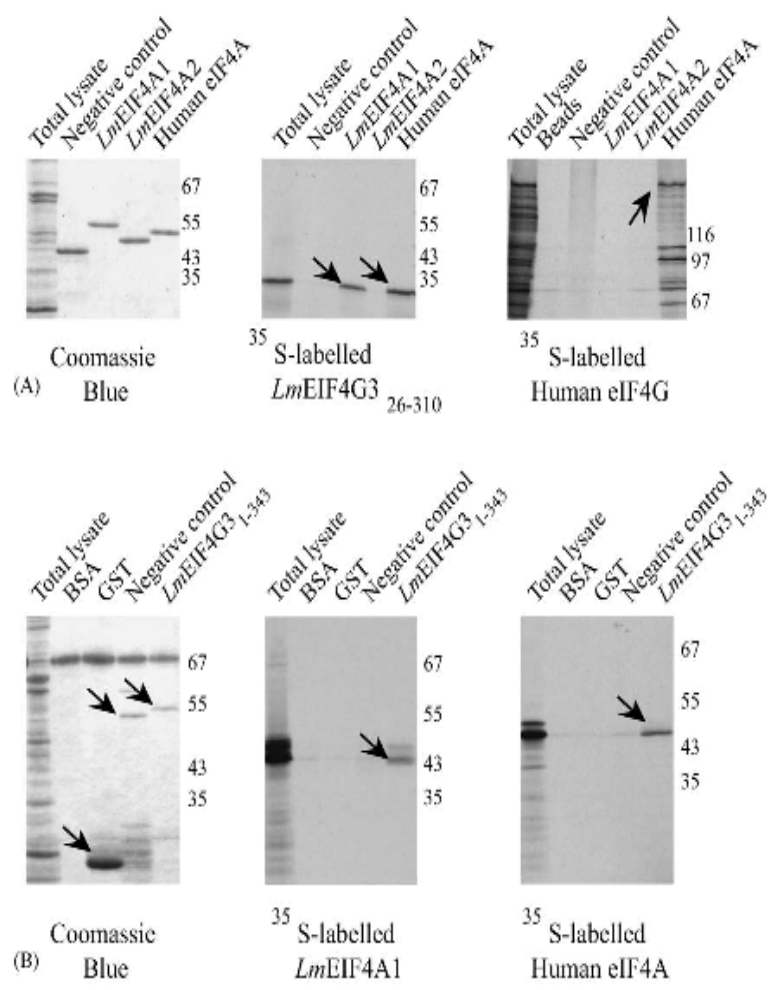

Fentomoles No. of $L$. of GST-elF major cells

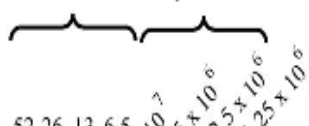

$5226136.504+25 y^{2}$

LmEIF4G3

(C)

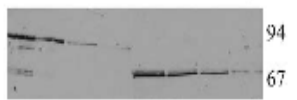

Fig. 8. Andysis of the interaction between human and $L$. major eIFtA homologues with the $L m E I F+G 3$ protein. (A) Pull-down ascay uxing recombinant His-tagged LmEIF4AI-2 and human eIF4A incubated with either ${ }^{35}$ S-labelled human eIF $4 G$ or $L m E I F+G 3_{30-310}$. Proteirs bound to the Ni-NTA bends were analysed through 15\% ( $\mathrm{LmEIF}+\mathrm{G}_{30-310}$ ) or $10 \%$ (human eIF+G) SDS-PAGE. Left panel: Coomascie Blue strined gel showing total translation extract (Total lysate) $x$ well as the recombinant His-tagged proteirc. Middle panel: autoradiography showing specific binding (arows) between LmEIF 4Al-His/labelled LmEIF4G326-310 and human eIF4A-Hiz/labelled LmEIF4G326-310. Right panel: pocitive control of a 10\% SDS-PAGE showing the specific binding between

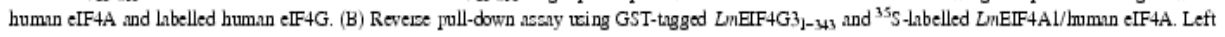
panel: 15\% SDS-PAGE showing total tranclation extract and recombinant GST-tagged proteins. Middle and right panele: autoradiography showing specific binding (arrows) between $L m E I F 4 G 3_{1}-u_{3}$-GST/labelled $L m E I F 4 A 1$ and $L m E I F 4 G 3_{1-43}$-GST/Labelled human eIF4A. (C) Quantitation of $L m E I F 4 G 3$ in $L$ major promastigote. The quantitation of the endogenous protein levele was performed $x$ described in Fig. 2 with recombinant GST-LmEIF 4 G $_{1}$ 1-66 $_{\text {and }}$ and isoform specific polyclonal sera againt $L m E I F+G 3$. 
complex formation on the EMCV IRES [28]. Only labelled LmEIF4G326-310 was able to bind efficiently to LmEIF4A1 and to human eIF4A as shown in Fig. 8A (middle panel). No specific binding by the LmEIF4G1-2 constructs to the various recombinant proteins was obselved (data not shown). Moreover, even though LmEIF4A1 and 2 share a similarity of $71 \%$, no significant binding by any of the three LmEIF4G proteins to LmEIF4A2 was observed (Fig. 8A and data not shown).

To confirm the specific interaction between LmEIF4G326-310 with LmEIF4A1, we expressed the $\mathrm{N}$-terminal half of LmEIF4G3 containing the HEAT domin ( $\left(m \mathrm{EIF}_{4} \mathrm{G}_{1-310}\right)$ in $E$. coli fused to GST and tested it in a reverse pull-down assay. Here, the GST fusion was immobilised on glutathione-Sepharose and incubated with
${ }^{35}$ S-labelled LnEIF4Al and human eIF4A (Fig. 8B). As negative controls, we used GST on its own and a morine GST-cde2 fusion protein of a similar size to the GST-LmEIF4G3 $3_{1-310}$ protein. This reverse assay confirmed the interaction between the GST-LmEIF4G3 $3_{-310}$ fusion protein and both labelled LmEIF4A1 and human eIF4A (Fig. 8B-middle and right panels). In summary, the pulldown experiments indic ate that of the three $L$ major putative eIF4Gs tested, only LmEIF4G3 interacts specifically with LmEIF4Al as well as with human eIF4A.

Thus, our results are consistent with roles for both LmEIF4A1 and LmEIF4G3 in the process of parasite RNA translation. In order to compare the ratio of the eIF $4 \mathrm{~A} / 4 \mathrm{G}$ homologues in $L$ major with those described for other eukaryotes, an antibody wasraised against the His-LmEIF4G326-310
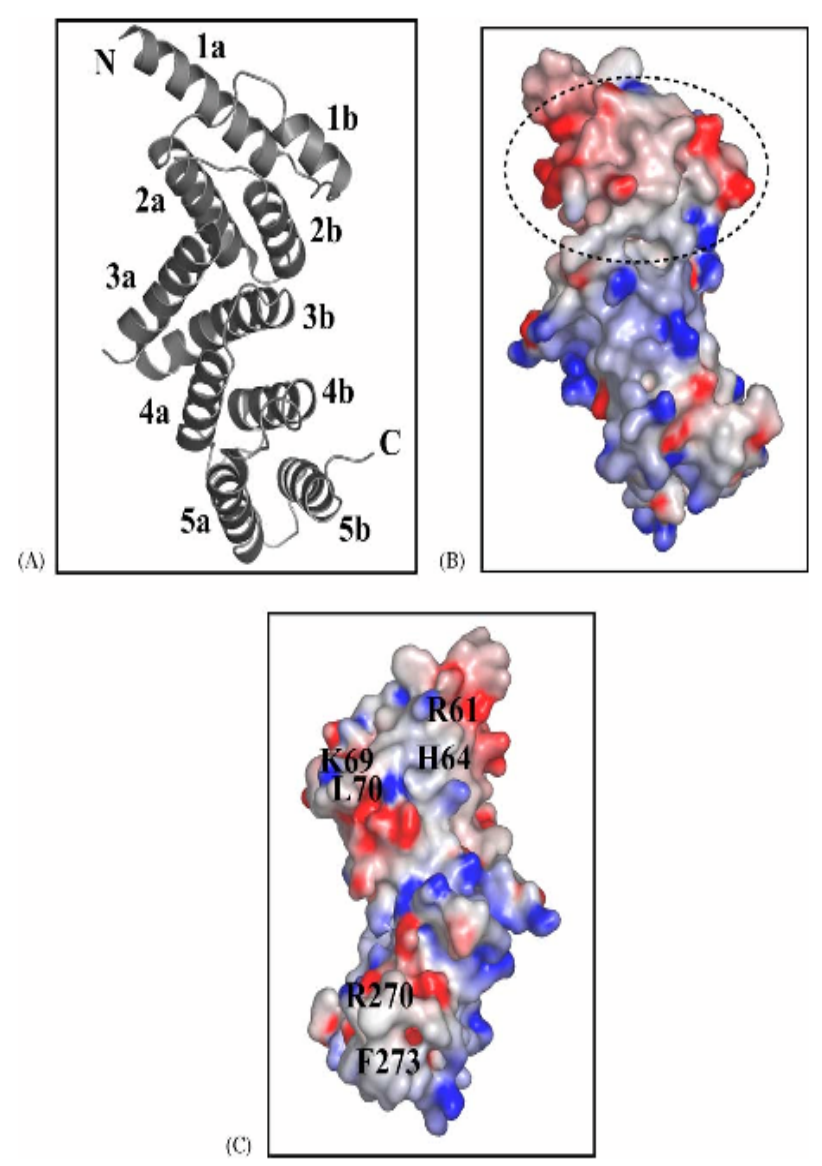

Fig. 9. Model of the stucture of the LmEIF 4G3 HEAT domain. (A) Ribbon dingrnm of the structure of the predicted LmEIF4G3 HEAT domin with the concave sufface on the right and the convex sufface on the left. The $\alpha$ helices are labelled as described for human eIF4GII [26] and as shown in Fig. 7. (B)-(C) Grasp representation of the suffice of the domain colored coded for electroctatic potentil (red <-8kB T; blve > \&l:BT). A and B represent identical views of the molecule whilst in C the opposite side of the molecule (rotated $180^{\circ}$ about the long axis relative to (A) and (B)), predicted to be involved in the intenction with eIF 4A, is shown. In (B) the dotted circle delimit the region in $L m E I F 4 G 3$ which differs from the humn eIF4GII HEAT domain. Highlighted in (C) are the amino acide R61, H64, K69, L70, R270, F273, equivalent to amino acide implicated in the binding to eIF4A in the mammalim protein. 
to enable quantitation of the endogenous $L$ major $L m E I F 4 G 3$ levels, as previously done for $L m E I F 4 E 1-3$ and $L m E I F 4 A 1-$ 2, using full length GST-LmEIF4G3 ${ }_{1-636}$ for comparison. This quantitation (Fig. 8C and Table 2) indicates that, at about (4-8) $\times 10^{3}$ molecules per cell, LmEIF4G3 is present at about twice the level observed for LmEIF4E1 in L. major promastigotes, and is about 10- and 50-fold less abundant than $L m E I F 4 E 3$ and $L m E I F 4 A 1$, respectively. The large differences in concentration between the eIF $4 \mathrm{E} / \mathrm{eIF} 4 \mathrm{G}$ or eIF4A/eIF4G homologues are similar to those reported in yeast, where the eIF4G levels are about 20- and 45-fold less abundant than those of eIF4E and eIF4A, respectively [56]. However, considering that the number of LmEIF4G3 molecules in L. major is about one-third to one half of the levels in yeast, it is unclear whether the intracellular levels of $L m E I F 4 G 3$ would be sufficient to support translation in L. major. While it would appear to function in translation or translational control, based on its sequence and the $L m E I F 4 A$ binding data, we cannot rule out contributions from the other eIF4G homologues in these processes.

\subsection{Molecular modelling of the LmEIF 4G3 HEAT domain}

So far, the full length eIF4G has been refractory to structural studies. Only recently have individual domains within this protein, such as the central HEAT domain from humn eIF4GII [26] and the eIF4E interacting region from yeast eIF4GI [71], been solved at the structural level. Given the evidence obtained above implicating $L m E I F 4 G 3$ in translation in $L$. major, we decided to attempt the molecular modelling of LmeIF4G3. However, its very short N-terminus, only 50 amino acids long, plus the apparent lack of the consensus eIF4E binding motif (see Section 4), indic ates that it may not bind eIF4E factors in the same manner as shown for the mammalian and yeast proteins $[53,54,71]$. Nevertheless, the LmeIF4G3 HEAT domain could be modelled and its structural features as sociated with eIF4A binding were compared with the structure of the human eIF4GII HEAT domain.

Fig. 9A shows the ribbon drawing of the predicted threedimensional structure of the LmEIF4G3 HEAT domin. Absent from the drawings are the two segments corresponding to two loops (amino acids 128-140 and 161-178) which were not structured in the original human protein. As for the LmEIF4E1 model, the overall quality of the final model was confirmed by the programs PROCHECK, Verify 3D and WHATIF. The LmEIF4G3 HEAT domain folds into the same crescent-shaped molecule described for the human protein, with the five pairs of antiparallel $\alpha$ helices forming the same double layer with the convex and concave surfaces formed by the A and B helices, respectively (Fig, 9A). A major difference between the Leishmania and mammanian protein arises from the analysis of the surface electrostatic potential of the model performed with the progam GRASP (Fig. 9B and C). This difference is concentrated in the region which in the human protein has been implicated in the interaction with the
EMCVIRES [26]. In human eIF4GII this region has an overall positive charge but in the LmEIF4G3 HEAT domain the equivalent region is negatively charged (Fig. 9B). In contrast, the region involved in the eIF4A interaction presents a surface electrostatic potential similar to the human model and all the conserved amino acids implicated in the interaction with eIF4A (R61, H64, K69, L70, R270 and F273 equivalent to R756, R759, K764, L765, R968 and F971 in the mammalian protein) are positioned adequately for the interaction to occur (Fig. 9C and [26]). Again these results support arole for $L m E I F 4 G 3$ in translation, although the lack of a possible eIF4E interacting region and the differences in the putative RNA binding side of the protein's HEAT domin might indicate a regulatory role in protein synthesis or a different mechanism for its function in translation initiation.

\section{Discussion}

The three eIF4F initiation factors have multiple is of orms in $L$. major protozoa. This complexity is reflected in $T$. brucei (which have similar isoforms) and indicates that they all have conserved roles in the parasites. Our results show that for each factor, one of the L. major forms seems to fulfil, inpart at least, the expected characteristics of a translation initiation factor. However we believe that under more stringent assays, at least some of the other isoforms may also have specific roles in translation. For instance, it is possible that the various eIF4E homologues have different affinities for the parasite cap4 structure than those observed for the cap-Sepharose resin. Recently the chemical synthe sis of the trypanosomatid cap 4 has been achieved and the binding of a Leishmania eIF4E homologue, LeishIF4E-1 (equivalent to the LmEIF4El protein described here), to this cap4 structure investigated through fluorescence titration measurements [72,73]. LeishIF4E-1 bound to both the cap4 and $\mathrm{m}^{7} \mathrm{GTP}$ with very similar affinities, confirming the results obtained from the simple cap binding ass ay shown in Fig. 3 as well as our sequence and structural analysis. It remains to be seen whether either LmEIF4E2 or 3 , which do not bind cap-Sepharose, as well as $L m E I F 4 E 4$, not yet investigated experimentally, would be able to bind the cap4 structure. It is also possible that any one of these proteins may require ass ociation to the eIF4G homologues in order to bind efficiently to the cap, since in other eukaryotes the complex eIF4E/eIF4G binds with a higher affinity to the cap structure than eIF4E alone [71]. Alternatively, one last possibility would be for some of these other eIF4E homologues to act as regulators of $L m E I F 4 E 1$ function by competing with it for binding to eIF4G.

The existence of multiple isoforms for the eIF4F subunits in other eukayotes, especially pluricellular organisms, may be associated with different patterns of tissue expression and during development. Insights into the role of the multiple isoforms come from the nematode system which in many aspects regarding mRNA metabolism can be compared to the trypanosomatids. In Ascaris humbricoides, a $22 \mathrm{nt}$ SL se- 
quence and its ass $\propto$ ciated trimethylated cap, trans-spliced to

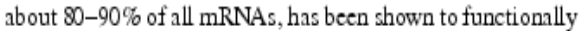
collaborate to enhance translation, very likely at the level of initiation [10]. It is not known how these features influence protein synthesis, but it seems likely that they do so via transacting factors. The presence of multiple eIF4E homologues in C. elegans is also reminiscent of what we see in the parasite system [51]. The five nematode homologues differ in cap binding affinity, requirement for viability [74] and possible roles in development [75]. In the case of the trypanosomatid protozoan unicellular organisms, the multiple eIF4F isoforms could be associated with their different life stages or be required for the translation of different classes of $m R$ NAs. Indirect evidence for the second hypothesis come s from wheat germ, where two different eIF4F isoforms have been described, with distinct eIF4E and eIF4G subunits, which differ in their ability to translate mRNAs containing structured regions in their $5^{\prime}$ UTR as well as uncapped mRNAs and dicistronic messages [76].

Our own results tend to indicate a stage specific expression for at least some of the eIF4E orthologues, since in $T$. bricei we have observed that the TbEIF4E3 protein is expressed at high levels in the procyclic stage and it is absent from bloodstream forms (Dhalia et al., unpublished results). The mRNA encoding LmEIF4E 1 contains in its 3'UTR a sequence similar ( $68 \%$ identity) to the regulatory element found in the Leishmania amastin mRNA $[77,78]$. This element is found in a number of Leishmania mRNAs, several of which are differentially expressed in $L$ donovani amastigotes, and can confer amastigote-specific expression to a reporter mRNA possibly by regulating translation instead of stability [78]. It seems plausible that the expression of LmeIF4El may be enhanced at the amastigote stage specially considering that, assuming a similar behaviour to the $T$. bnuce i orthologue, LmeIF4E3 (the most abundant of the three eIF4E proteins in promastigotes), may be absent from the Leishmania mammalian form as well. Additional evidence for the stage specific expression of the eIF4E homologues was provided recently by microarray analysis, where the LmEIF4E2 coding sequence was found within a subset of genes preferentially expressed in metacyclic populations of $L$. major [79]. Regarding the eIF4A subunit, the differences in levels between the two Leishmania eIF4A orthologues leave no doubt as to the relevant role for $L m E I F 4 A 1$ in translation in promastigotes. Since equivalent levels of expression have been reported for $L m E I F 4 A 1$ in both promastigote and amastigote stages of the Leishmania life cycle [37], it is unlikely that LmEIF4A2 would replace it to a significant extent in the mammalian stage.

The multiple candidate eIF4G homologues identified in $L$. major add yet a new level of complexity to the study of translation initiation in this parasite. None of the identified homologues can be unambiguously assigned the role of a translation factor. Although LmEIF4G3 (and possibly the related LmEIF4G4) seems to be clearly involved in translation, its very short $\mathrm{N}$-terminus may not accommodate binding sites for both eIF4E and PABP, as in other eukaryotes. It is possible that both $L m E I F 4 G 3-4$ function as a translational regulator/inhibitor as proposed for the mammalian protein p97/DAP-5/NATl (reviewed in [12]), which is homologous to the C-terminal two-thirds of mammalian eIF4G but lacks the N-terminal one-third including the EIF4E- and PABPbinding sites. However none of the other eIF4G homologues from $L$. major share any homology to LmEIF4G3-4 outside the HEAT domain and despite having much longer $\mathrm{N}$-termini, they do not have well defined eIF4E-binding motifs.

To continue the comparis on with the nematode system, we searched for eIF4G homologues in the $C$. elegans genome. Strikingly, we found only one cle ar homologue which contains what seems to be a modified eIF4E binding sequence, FGRDFMV (GenBank accession NP495729). Similar sequences FSLDEVV and FSLERVL are present in the short N-termini of LmEIF4G3 and LmEIF4G4 respectively and variations of it can also be found in possible $T$. brucei and $T$. cnizi orthologues. Their similarity to the nematode sequence suggests that all three sequences may bind eIF4E proteins, in which case both $L m E I F 4 G 3$ and $L m E I F 4 G 4$ could be true eIF4G orthologues. However considering the possible deviation from the eIF4E binding consensus the potential eIF4E binding sites need to be determined experimentally.

In summary, the results reported here indicate that LmEIF4E1, LmEIF4Al and LmEIF4G3 are the factors that functionally interact with the cap structure or each other, suggesting that they perform essential roles in protein synthesis. In order to assess their importance for cellular viability, as well as of the other homologues identified, we are currently performing RNA interference experiments in $T$. brucei. To address their function we will continue the protein-protein poll down assays and investigate possible eIF4G/eIF 4E interactions. Finally expression analysis will be carried out so as to identify patterns of expression during the parasite life cycle for the various homologues. We expect with these studies to define, within the homologues already identified, which ones are required for translation initiation in trypanosomatids and whe ther their expression/activity can be regulated during the different stages of differentiation of these unique organisms.

\section{Acknowledgements}

This work was supported by grants/studentships from CNPq, CAPES, FIOCRUZ, FACEPE and the Wellome Trust. Technical assistance to grow the Leishmania cells was provided by L. Rocha. We thank A. Ivens for the gift of cosmid DNAs and help with some preliminary sequence data. The human eIF4A cDNA in plasmid $\mathrm{pET}\left(\mathrm{His}_{6}-\mathrm{EF} 4 \mathrm{~A}\right)$ and the $X$. laevis eIF4E cDNA in pSP64TEN were kind gifts from I. Ali, R. Jacks on and S. Morley, respectively. We would also like to acknowledge E. Cupolillo for the L. major Friedlin strain, M. Carrington for access to preliminary $T$. brucei eIF4E sequences and A. Git for the GST-cde2 clone. Finally, we are deeply indebted to 0 . Thiemann and D.H.F Souza for 
allowing us access to the computing facilities necess ay to the modelling work. Sequencing of $L$ major was accomplished as part of the Leishmania genome network and was financially supported by the Wellcome Trust, Burroughs Wellc ome Fund, the EU, WHO/TDR and NIAID. This work could not be accomplished as such without the free availability of the sequences produced by this network.

\section{Appendix A. Supplementary data}

Supplementary data associated with this article can be found, in the online version, at 10.1016/j.molbiopara.2004. 12.001 .

\section{References}

[1] Muhich ML, Boothroyd JC. Polycistronic traxecipt in trypunocomes and their accumulation during heat shock: evidence for a precursor role in mRNA synthesis. Mol Cell Biol 1988;8:3837-46.

[2] Ullv E, Txchudi C. Tran splicing in typanocomes requires methyLation of the $5^{\prime}$ end of the spliced lender RNA. Proc Natl Acad Sci USA 1991:88:1007+8.

[3] Campbell DA, Thomas S, Sturm NR. Transcription in kinetopl $x$ tid protozoa: why be nomal? Microbes Infect 2003:5:1231-40.

[4] Ling XH, Haitan A, Uliel S, Michneli S. Trans and cis splicing in trypanosomatids: mechnnism, factos, and regulation. Eulkryot Cell 2003:2:830-40.

[5] Clayton CE. Life without transcriptional control? From fly to man and back again. EMBO J 2002;21:1881-8.

[6] Bang JD, Crain PF, Hashizume T, McClockey JA, Boothroyd JC. Mase spectrometry of mRNA cap 4 from trypnnocomatict revents two novel mucleocides. J Biol Chem 1992:267:9805-15.

[7] Nileen TW. Trans-splicing: an update. Mol Biochem Parxitol 1995;73:1-6.

[8] Pascolo E, Blonkik C, Shire D, Toulme JJ. Antisenre effect of oligodeoxymucleotides complementary to the mini-exon sequence of the protozon parxite Lashmania amazonensis. Biochimie 1993;75:43-7.

[9] Ramazeilles C, Mishra RK, Moreau S, Pascolo E, Toulme JJ. Antisense phosphosothioate oligomucleotides: selective killing of the intncellular parnsite Leishnnania anazonensis. Proc Natl Acad Sci USA 1994:91:7859-63.

[10] Mroney PA, Denler IA, Darzynkiewicz E, L.neve R, Nilen TW. Moct mRNAs in the nematode Ascaris lumbricaides are transspliced: a role for spliced leader addition in translational efficiency. RNA 1995:1:71+23.

[11] Zeiner GM, Sturm NR, Campell DA. The Leishmania tarentolac spliced leader cont.ins determinant for aseociation with polyøomes. J Biol Chem 2003:278:38269-75.

[12] Gingras AC, Rught B, Sonenberg N. eIF4 initiation factor: effectors of mRNA recruitment to ribocomes and regulators of tranclation. Annu Rev Biochem 1999:68:913-63.

[13] Heshey JWB, Merrick WC. Pathway and mechanirm of initiation of protein synthesis. In: Sonenberg N, et al., editos. Translational control of gene expression. New Yorl: Cold Spring Hubor Laboratory Press: 2000. p. 33-88.

[14] Pestova TV, Kolupaeva VG, Lomalein IB, et al. Molecular mechanisme of tranelation initiation in euleryotes. Proc Natl Acad Sci USA 2001:98:7029-36.

[15] Sonenberg N, Dever TE. Euknyotic translation initiation factors and regulators. Curr Opin Struct Biol 2003;13:56-63.
[16] Sonenberg N, Gingras AC. The mRNA 5' cap-binding protein eIF4E and control of cell growth. Curr Opin Cell Biol 1998:10:268-75.

[17] R.unght B, Gingras AC. eIF4E activity is regulated at multiple level. Int J Biochem Cell Biol 1999:31:43-57.

[18] Scheper GC, Proud CG. Does phocphorylation of the cap-binding protein eIF4E phay a role in tranclation initiation? Eur J Biochem 2002;269:5350-9.

[19] Luking A, Stahl U, Schmidt U. The protein frmily of RNA helicnes. Crit Rev Biochem Mol Biol 1998:33:259-96.

[20] Linder P. Yesst RNA belicases of the DEAD-box family insolved in tranclation initiation. Biol Cell 2003:95:157-67.

[21] Roc.ls S, Linder P. DEAD-box proteins: the driving forces behind RNA metabolism. Nat Rev Mol Cell Biol 2004:5:232-41.

[22] Prevot D, Darlix JL, Ohlmann I. Conducting the initiation of protein synthesis: the role of eIF4G. Biol Cell 2003;95:141-56.

[23] Mader S, Lee H, Parce A, Sonenberg N. The translation initiation factor eIF-4E binds to a common motif shared by the tranclation factor eIF-4 gamma and the translational repressors $4 E$-binding proteins. Mol Cell Biol 1995;15:4990-7.

[24] Taun Jr SZ, Sachs AB. Association of the yeast poly(A) tril binding protein with translation initiation factor eIF-4G. EMBO J 1996;15:7168-77.

[25] Imataka H, Gradi A, Sonenberg N. A newly identified N-terminal amino acid sequence of human eIF $4 \mathrm{G}$ binct poly $(\mathrm{A})$-binding protein and functions in poly(A)-dependent translation. EMBO J $1998 ; 17: 7480-9$.

[26] Marcotriginno J, Lomakin IB, Sonenberg N, Pestown TV, Hellen CU, Burley SK. A conserved HEAT domin within eIF 4 G direct ascembly of the translation initiation machinery. Mol Cell 2001;7:193203.

[27] Korneeva NL, Lamphear BJ, Hennigan FL, Rhoadz RE. Mutully coopentive binding of euksyrotic translation initiation factor (eIF) 3 and eIF4A to human eIF4G-1. J Biol Chem 2000;275:4136976.

[28] Lomalin IB, Hellen CU, Pestova TV. Physical associntion of eularyotic initiation factor $4 \mathrm{G}$ (eIF4G) with eIF4A strongly enhunces binding of eIF $4 G$ to the internal ribocomal entry site of encephalomyocaditis virus and is required for internal initiation of tranclation. Mol Cell Biol 2000:20:6019-29.

[29] Imatala $\mathrm{H}$, Sonenberg N. Human eularyotic translation initintion factor $4 \mathrm{G}$ (eIF+G) pocsesses two separate and independent binding sites for eIF4A. Mol Cell Biol 1997:17:6940-7.

[30] Morino S, Imatala H, Svittin YV, Pestova TV, Sonenberg N. Evkayotic tranclation initiation factor $4 \mathrm{E}$ (eIF4E) binding site and the middle one-third of eIF4GI constitute the core domain for capdependent translation, and the C-terminal one-third functions as a modulatory region. Mol Cell Biol 2000:20:468-77.

[31] Pyronnet S, Imataka H, Gingras AC, Fulkunga R, Hunter T, Sonenberg N. Humn eulanyotic trandation initiation factor $4 G$ (eIF4G) recruits mnlel to phosphorylate eIF4E. EMBO J 1999:18: $270 \rightarrow 9$

[32] Nalamun Y, Hnchimoto T, Kлmuishi T, et al. Phylogenetic pocition of kinetoplastid protozon inferred from the protein plyylogenies of elongation factor 1alpha and 2. J Biochem (Tokyo) 1996:119:70-9.

[33] Batista JA, Teiseira SM, Doneleon JE, Kirchboft LV, de Sa CM. Characterization of a Trypunocoma cruzi poly(A)-binding protein and it genes. Mol Biochem Pansitol 1994:67:301-12.

[34] Hotchkiss TL, Nerantzakis GE, Dills SC, Shang L, Read LK. Trypanosoma bncei poly(A) binding protein I cDNA cloning, expression, and binding to $5^{\prime}$ untranslated region sequence elements. Mol Biochem Parasitol 1999:98:117-29.

[35] Bate EJ, Knuepfer E, Smith DF. Poly(A)-binding protein I of Leish mania: functional andysis and localiention in typanosomatid parasites. Nucl Acids Res 2000;28:1211-20

[36] Skeily YA, Kennedy M, Knufman D, et al. LeIF: a recombinut Leishmania protein that induces an IL-12-mediated Thl cytokine profile. J Immunol 1998:161:6171-9. 
[37] Skeily YA, Guderinn JA, Benson DR, et al. A recombinant Leishmania antigen that stimulates human peripheral blood monomuclear cells to express a Thl-type cytoline profile and to produce interleukin 12. J Exp Med 1995;181:1527-37.

[38] Kumar S, Tammen K, Jalobcen IB, Nei M. MEGA2: molecular erolutionuy genetics anlysis software. Bioinformatics 2001:17:1244-5.

[39] Sritou N, Nei M. The neighbor-joining method: a new method for recorrtucting phylogenetic trees. Mol Biol Evol 1987;4:406-25.

[40] Jones DT. GenTHREADER: an efficient and reliable protein fold recognition method for genomic sequences. I Mol Biol $1999: 287: 797-815$

[41] Mucotrigino J, Gingres AC, Sonenberg N, Burley SK. Cocryetal structure of the mescenger RNA 5 cap-binding protein (eIF4E) bound to 7-methyl-GDP. Cell 1997:89:951-61.

[42] Sali A, Blundell TL. Compunative protein modelling by satisfaction of spatial rectraints. J Mol Biol 1993:234:779-815.

[43] Laclows ki RA, MacArthur MW, Moss DS, Thornton JM Procheck: a prognm to check the stereochemical quality of protein stuctures. J Appl Crystallogr 1993;26:283-91.

[44] Luthy R, Bowie JU, Eisenberg D. Acsessment of protein modele with three-dimensional profiles. Nature 1992;356:83-5.

[45] Vriend G. WHATIF: a molecular modelling and drug design program. J Mol Graph 1990:8:52-6.

[46] de Melo Neto OP, Standut N, de Sa CM Autoregulation of poly(A)-binding protein synthesis in vitro. Nucl Acids Res 1995:23:2198-205.

[47] Minshall N, Thom G, Standut N. A conserved role of a DEAD box helicase in mRNA making. RNA 2001;7:1728-42.

[48] Pestova TV, Hellen CU, Shat ky IN. Canonical eulayotic initiation factors determine initiation of translation by internal ribosomal entry. Mol Cell Biol 1996:16:6859-69.

[49] Melo EO, Dhalia R, de Sa CM, Standart N, de Melo Neto OP. Identification of a C-terminal PABP-PABP interaction domain: role in coopentive binding to poly $(\mathrm{A})$ and efficient cap distal tanslational repression. J Biol Chem 2003;278:46357-68.

[50] Clayton C, Adrms M, Almeidr R, et al. Genetic nomendsture for Irypanosoma and Leishmania. Mol Biochem Pansitol 1998:97:221-4.

[51] Jankowaka-Anyzzka M, Lamphear BJ, A.smodt EJ, et al., Rhands RE. Multiple isoforms of euksyotic protein synthesis initis. tion faxtor $4 \mathrm{E}$ in Caenoriabditis elegans can distinguich between mono-nd trimethylated mRNA cap structures. J Biol Chem 1998:273:10538-42

[52] Matswo H, Li H, McGuire AM, et al. Structure of translation factor eIF4E bound to $m 7$ GDP and intenction with $4 E$-binding protein. Nat Struct Biol 1997:4:717-24

[53] Mucotriginno J, Gingras AC, Sonenberg N, Burley SK. Capdependent trarclation initiation in eulsayotes is regulated by a molecular mimic of eIF4G. Mol Cell 1999:3:707-16.

[54] Niedzwieckn A, Mrrcotriginno J, Stepinski J, et al. Biophysical studies of eIF 4 E cap-binding protein: recognition of mRNA $5^{\prime}$ cap structure and synthetic fragments of eIF4G and 4E-BPl proteins. J Mol Biol 2002:319:615-35.

[55] Ptuchkina M, von der Harr I, Vacilescu S, Frank R, Birkenhnger R, MeCarthy JE. Cooperative modulation by eIF $4 \mathrm{G}$ of eIF 4 E-binding to the mRNA $5^{\prime}$ cap in yeast involve a site partially shred by p 20 . EMB O J 1998;17:4798-808.

[56] von der Harr T, MoCarthy JE. Intracellular trauslation initiation factor levele in Saccharomyces cerevisiae and their role in cap-complex function. Mol Microbiol 2002;46:531-44.

[57] Nicholle A, Shap KA, Honig B. Protein folding and ascocintion: incighte from the interfacial and thermodynamic properties of hydrocarbone. Proteins 1991:11:281-96.

[58] Li Q, Imataka H, Morino S, et al. Eukaryotic tranelation initistion factor $4 \mathrm{AIII}$ (eIF4AIII) is functionlly distinct from eIF4AI and eIF4AII. Mol Cell Biol 1999;19:7336-46.
[59] Lu J, Aoli H, Ganoza MC. Molecular churacterization of a prokayotic translation factor bomologous to the eukuryotic initiation factor eIF4A. Int J Biochem Cell Biol 1999:31:215-9.

[60] Story RM, Li H, Abeloon JN. Crystal structure of a DEAD box protein from the hyperthermophile Methanococcus jannasdiii. Proc Natl Acad Sci USA 2001:98:1465-70.

[61] Tanner NK, Cordin O, Banroques J, Doere M, Linder P. The Q motif. a newly identified motif in DEAD box helicases myy regulate ATP binding and hydrolyzis. Mol Cell 2003:11:127-38.

[62] Curuthers JM. Johnoon ER, McKay DB. Crystal stucture of yenst initintion factor 4A, a DEAD-box RNA belicase. Proc Natl Acad Sci USA 2000;97:13080-5.

[63] Mirchnll N, Thom G, Standat N. A conserved role of a DEAD box helicase in mRNA masking. RNA 2001:7:1728-42.

[6+] Coller IM, Tucker M, Sheth U, Valencia-Sanchez MA, Parker R. The DEAD box helicxe, Dhhlp, functions in mRNA decapping and interacte with both the decapping and dendenylase complexes. RNA 2001:7:1717-27.

[65] Dunc.n R, Milburn SC, Hershey JW. Regulated phosphorylation and low abundance of HeL.a cell initiation factor eIF-4F cuggest a role in translational control. Heat abock effects on eIF-4F. J Biol Chem 1987:262:380-8.

[66] Ruv M, Ohmmn T, Morley SJ, Pain VM. A reevaluation of the cap-binding protein, eIF $4 \mathrm{E}$, as a nate-limiting factor for initiation of tranclation in reticulocyte lysate. J Biol Chem 1996;271: $9983-90$.

[67] Asnno K. Shlev A. Phn L, et al. Multiple roles for the C-terminal domin of eIF5 in translation initintion complex ascembly and GTPase activation. EMBO J 2001;20:2326-37.

[68] He H, won der Harr T, Singh CR, et al. The yeast eularyotic initiation factor 4 G (eIF4G) HEAT domin interacts with eIFI and eIF5 and is involved in stringent AUG selection. Mol Cell Biol $2003 ; 23: 5431-45$.

[69] Taun Jr SZ, Wells SE, Deadorff JA, Sachs AB. Tnuslation initiation factor eIF4G mediates in vitro poly(A) tril-dependent traxelation. Proc Natl Acad Sci USA 1997:94:9046-51.

[70] Joshi B, Yan R, Rhoade RE. In vitro synthesis of hmmn protein synthecis initiation factor 4 gamma and it localization on 43 and 48 S initintion complexes. J Biol Chem 1994:269:2048-55

[71] Groce JD, Moerke NJ, von der Har T, et al. Ribøcome loading onto the mRNA cap is driven by confomational coupling between eIF $4 G$ and eIF4E. Cell 2003;115:739-50.

[72] Lewdorowicz M, Yoffe Y, Zuberek J, et al. Chemical synthesis and binding activity of the trypnosomatid cap-4 stucture. RNA 2004;10:1-10.

[73] Yoffe Y, Zuberek J, Lewdorowicz M, et al. Cap-binding activity of an eIF4E homolog from Leishmania. RNA 2004;10:1764-75.

[74] Keiper BD, L.mplpear BJ, Dechpunde AM, et al. Functional churacterization of five eIF4E isoforme in Cachorhabditis elegans. J Biol Chem 2000;275:10590-6.

[75] Amin A, Keiper BD, Kawasalki I, et al. An isoform of eIF4E is a component of gem gnuules and is required for spermatogenesis in C. elegans. Development 2001;128:3899-912.

[76] Gallie DR, Browning KS. eIF4G functionlly differs fiom eIFiso 4 G in promoting internal initiation, com-independent translation, and trarclation of structured mRNAs. J Biol Chem 2001;276:36951-60.

[77] Wu Y, El Falthry Y, Sereno D, Trmar S, Papndopoulou B. A new developmentally regulated gene family in Leishmania amastigotes encoding a homolog of amsetin sufface proteins. Mol Biochem Parasitol 2000;110:345-57.

[78] Boucher N, Wu Y, Dumx C, et al. A common mechnniem of strgeregulated gene expression in Leishniania mediated by a conserved 3 '-untraclated region element. J Biol Chem 2002:277:19511-20.

[79] Almeidn R, Gilmutin BJ, McCann SH, et al. Exprescion profiling of the Leishunania life cycle: CDNA arnys identify developmentally regulated genes present but not annotated in the genome. Mol Biochem Parxitol 2004:136: 87-100. 


\title{
The two elF4A helicases in Trypanosoma brucei are functionally distinct
}

\author{
Rafael Dhalia, Nina Marinsek ${ }^{1}$, Christian R. S. Reis, Rodolfo Katz, João R. C. Muniz², \\ Nancy Standart ${ }^{1}$, Mark Carrington ${ }^{1}$ and Osvaldo P. de Melo Neto*
}

Centro de Pesquisas Aggeu Magalhães, Fundação Oswaldo Cruz, Avenue Moraes Rego s/n, Campus UFPE, Recife PE 50670-420, Brazil, 'Department of Biochemistry, University of Cambridge, 80 Tennis Court Road, Cambridge CB2 1GA, UK and ${ }^{2}$ Instituto de Física de São Carlos, Universidade de São Paulo, Caixa Postal 369, São Carlos SP 13560-970, Brazil

Received February 1, 2006; Revised March 4, 2006; Accepted April 6, 2006

\section{ABSTRACT}

Protozoan parasites belonging to the family Trypanosomatidae are characterized by an unusual pathway for the production of mRNAs via polycistronic transcription and trans-splicing of a 5 capped mini-exon which is linked to the $3^{\prime}$ cleavage and polyadenylation of the upstream transcript. However, little is known of the mechanism of protein synthesis in these organisms, despite their importance as agents of a number of human diseases. Here we have investigated the role of two Trypanosoma brucei homologues of the translation initiation factor elF4A (in the light of subsequent experiments these were named as TbEIF4AI and TbEIF4AIII). elF4A, a DEAD-box RNA helicase, is a subunit of the translation initiation complex elF4F which binds to the cap structure of eukaryotic mRNA and recruits the small ribosomal subunit. TbEIF4AI is a very abundant predominantly cytoplasmic protein (over $1 \times 10^{5} \mathrm{molecules} / \mathrm{cell}$ ) and depletion to $~ 10 \%$ of normal levels through RNA interference dramatically reduces protein synthesis one cell cycle following double-stranded RNA induction and stops cell proliferation. Incontrast, TbEIF4Alll is a nuclear, moderately expressed protein $\left(\sim 1-2 \times 10^{4}\right.$ molecules/ cell), and its depletion stops cellular proliferation after approximately four cell cycles. Ectopic expression of a dominant negative mutant of TbEIF4AI, but not of TbEIF4AIII, induced a slow growth phenotype in transfected cells. Overall, our results suggest that only TbEIF4AI is involved in protein synthesis while the properties and sequence of TbEIF4AIII indicate that it may be the orthologue of elF4AIII, a component of the exon junction complex in mammalian cells.

\section{INTRODUCTION}

The flagellate protozoan parasites belonging to the family Trypanosomatidae include a number of important pathogens responsible for diseases of worldwide impact such as the Sleeping Sickness (Trypanosoma brucei), Chagas' Disease (Trypanosoma cruzi) and the vanious forms of Leishmaniasis (Leishmania sp.) (www.who.int/tdr). These organisms are unusual in a number of processes necessary for mRNA synthesis and maturation; transcription is polycistronic and monocistronic mRNAs arise after trans-splicing of a capped short exon on to the $5^{\prime}$ end and cleavage and polyadenylation at the $3^{\prime}$ end [reviewed in $\left.(1,2)\right]$. As a result of trans-splicing, the $5^{\prime}$ ends of mature trypanosomatid mRNAs all share the same $39 \mathrm{nt}$ leader sequence with a modified cap 4 structure (3). To date, little is known about how these mRNAs are translated, if major differences exist within the process of protein synthesis when compared with other eukaryotes and whether the common leader sequence influences how the mRNAs are recruited for translation.

In eukaryotes, protein synthesis is a complex process which requires a myriad of different macromolecules including RNAs and proteins. The critical initiation step requires a number of translation initiation factors (eIFs) whose activity can be highly regulated [for reviews see (4-7)]. Paramount within these factors is the heterotrimeric eIF4F complex, which is required for the recruitment of the small ribosomal subunit to the $5^{\prime}$ end of the mRNA. eIF4F is composed of the RNA helicase eIF4A, the capbinding protein $\mathrm{eIF} 4 \mathrm{E}$ and the large scaffolding protein eIF4G which mediates interactions between eIF4F and other translation factors as well as the small ribosomal subunit [reviewed in (8)].

"To whom correspondence should be addressed. Tel: 55812101 2636; Fax: 55813453 2449; Email: opmn@cpqam.fiocruz.br

DTe Author 2006. Published by Oxford University Press. All rights reserved.

The online version of this article has been published under an open access model. Users are entitled to use, reproduce, disseminate, or display the open access version of this article for non-commercial purposes provided that: the original authorship is properly and fully attributed; the Joumal and Oxford University Press are at tributed as the original place of publication with the correct citation details given; if an article is subsequently reproduced or disseminated not in its entirety but only in part or as a derivative work this must be clearly indicated. For commercial re-use, please contact journals.permissions@ oxfordjournals.org 
eIF4A is the prototype member of the DEAD-box family of RNA helicases which includes several proteins mainly involved in RNA metabolism. These proteins are classified within the superfamily II of a much larger group of related RNA and DNA helicases (9). The RNA helicases couple the hydrolysis of ATP to various activities relevant for RNA function such as rearrangement of inter- or intra-molecular RNA structures, dissociation of RNA-protein complexes and RNA unwinding. The DEAD-box family members are characterized by nine sequence motifs (I, Ia, Ib, II, III, IV, V and VI and the Q motif), as well as several individual amino acids, conserved among the various proteins assigned to this family [for reviews see $(10,11)]$. Structurally, eIF4A assumes a 'dumbbell' shape with two globular domains connected by a flexible linker (12). Comparison with the structure of related RNA and DNA helicases and the Methanococcus jannaschii DEAD-box protein, similar in size to eIF4A (13), have confirmed the basic overall structure of the core helicase domains. The various conserved motifs are positioned in the interface between the two domains and have been implicated in RNA binding and ATP binding and hydrolysis. However, little is known about the molecular basis for RNA specificity and helicase function [reviewed in $(11,14)]$. In translation initiation, eIF4A binds to the central region of eIF4G, via the eIF4G HEAT domain (15) and, in mammals at least, also to the eIF4G C-terminus $(16,17)$. eIF4A seems to be responsible for melting secondary structures along the mRNA $5^{\prime}$-untranslated region (5'-UTR), facilitating the binding of the small ribosomal subunit and the scanning of the leader region to locate the initiation codon $(18,19)$ [reviewed in $(4,6)$ ].

In mammals three different isoforms of eIF4A have been described. Both eIF4AI and II ( $90 \%$ identity between the two proteins) are able to reconstitute the eIF4F subunit and presumably have similar roles in translation $(20,21)$. In contrast, eIF4AIII, only $66 \%$ identical to mammalian eIF4AI, is functionally distinct. While eIF4AIII exhibits RNA-dependent ATPase activity and ATP-dependent RNA helicase activity, it does not support binding of the small ribosomal subunit to the mRNA, and inhibits translation in vitro (22). eIF4AIII localizes to the nucleus (23) and recent reports indicate that it may act as an anchoring factor for the exon junction complex (EJC), and is essential for nonsense-mediated decay (NMD) in mammals (24-30).

The mechanisms of translation initiation are virtually unknown in trypanosomatids. A Leishmania eIF4A homologue (called LeiF) was first described in Leishmania braziliensis and Leishmania major as a $45.3 \mathrm{kDa}$ antigen, expressed in both insect and mammalian stages of the parasite life cycle, but its role in translation was not investigated (31,32). Recently, our group has identified multiple L.major homologues for the three eIF4F subunits, all of which are conserved in T.brucei (33). We characterized two putative L.major eIF4A homologues, LmEIF4Al (LeiF) and LmEIF4A2, with 59 and $52 \%$ identities to human eIF4AI, respectively. When assayed with isoform specific antibodies these two factors differ significantly in abundance in L.major promastigotes. $L m E I F 4 A l$ is very abundant with over $10^{5}$ molecules/cell whilst $L m E I F 4 A 2$ is either absent or present at levels below $10^{4}$ molecules/cell. Furthermore, only $L m E I F 4 A 1$ was found to bind specifically to the HEAT domain of one of the Leishmania eIF4G homologues (33).
In this paper we take advantage of the genetic tools available for the study of gene function in T.brucei to extend this analysis of the two trypanosomatid eIF4A homologues. Initially, the mRNA and protein levels of the two Thrucei eIF4A orthologues were analysed during the life cycle. Their intracellular localization was identified through overexpression of enhanced yellow fluorescent protein (EYFP) fusions and their role for parasite viability investigated through RNA interference and overexpression of dominant negative mutants. Our results show that the T.brucei orthologue of $L m E I F 4 A l$ (named as $T b E I F 4 A I)$ is the functional homologue of the eIF4A present in eIF4F. As for the orthologue of $L m E I F 4 A 2$, it seems to be the functional homologue of the nuclear eIF4AIII present in higher eukaryotes and has been named here as TbEIF4AIII.

\section{MATERIALS AND METHODS}

Sequence analysis and molecular modeling

BLAST searches were carried out with the Thrucei genome sequences available at the Gene DB website of the Sanger Institute Pathogen Sequencing Unit (www.genedb.org). Further sequence searches, Clustal W alignments and molecular modeling were done as described previously (33).

\section{PCR and cloning methods}

The TbEIF4AI coding sequence was amplified from T.brucei Lister 427 genomic DNA (5'primer, AAG CTT CCG CCA

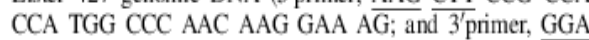
TCC AGA ACC CTC ACC AAG GTA GGC AGC; added restriction sites used in cloning are underlined) resulting in the entire open reading frame (ORF) flanked by sites for the enzymes HindIII and BamHI. The same strategy was used for the amplification of the TbEIF4AIII sequence (5'primer, AAG CTT CCG CCA CCA TGA CAG CAA CCG CAA GG; and 3'primer, GGA TCC AGA ACC GAA CTG TTC ACC GAC GTT TG). The amplified fragments were then cloned into the vector pGEM-T Easy (Promega) and sequenced. In order to express $\mathrm{N}$-terminal His-tagged fusion proteins both fragments were then recovered by digestion with HindIII and BamHI and subcloned into the same sites of a modified $\mathrm{pET} 15 \mathrm{~b}$ vector. To generate the TbEIF4AI-EYFP and TbEIF4AIII-EYFP constructs, the two eIF4A fragments were cloned into the HindIII and BamHI sites of p2215, a modified form of pLEW82 (34). To make p2215, the EYFP ORF (Clontech) was obtained as a BamHI/BgIII fragment and inserted into the BamHI site of pLEW82. On expression, the resultant fusion protein had the sequence: eIF4A C-terminal residue-GSGSGGG-EYFP. For the RNAi experiments the same two eIF4A DNA fragments were also subcloned into the HindIII/BamHI sites of the transfection vector p2T7-177 (35). Dominant negative mutants were made by altering the sequence of the DEAD box of the helicase (motif II in Figure 1) to DQAD $(11,36)$. Tetracycline-inducible expression of wild type and dominant negative forms of eIF4A was performed using p2280, a derivative of pLEW100 made by introducing a BamHI/BgIII DNA segment encoding three tandem myc epitope tags to its BamHI site. The two HindIII/ BamHI T.brucei eIF4A fragments were cloned into the same sites of 22280 resulting in the expression of fusion proteins with the myc epitope tags on their $\mathrm{C}$-terminus giving the sequence 


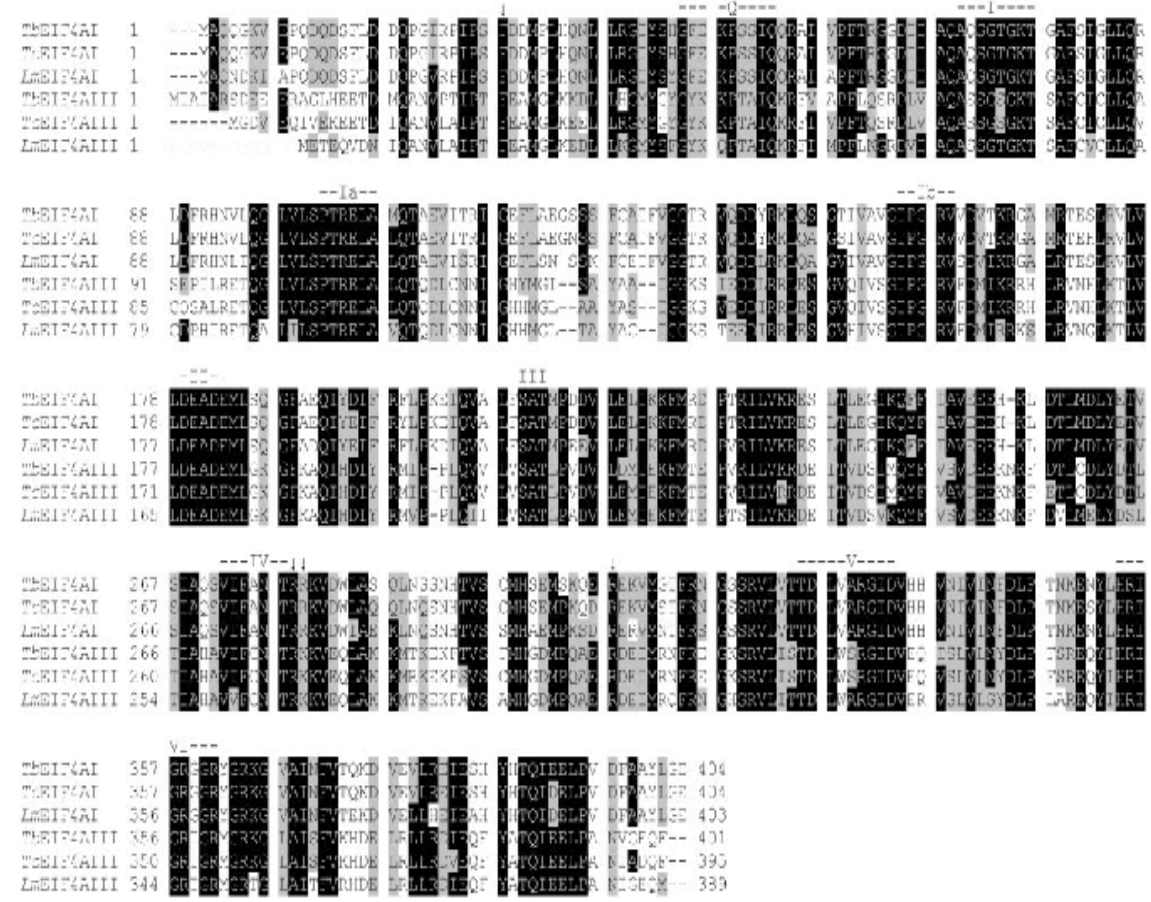

Figure 1. Sequence alignment comparing the T.brucei, T.cruzi and L.majar elF4A homologues. Sequences werealigned with the Clustal W program, from the Centre for Molecular and Biomolecular Informatics (http://www.cmbi.kun.nl/bioinftools/clustalw.shtml). Amino acids identical in $>60 \%$ of the sequences are highlighted in dark gray, while amino acids defined as similar, based on the BLOSUM 62 Matrix, on $>60 \%$ of the sequences, are shown in pale gray. When necessary, gaps were inserted within the various sequences (dashes) to allow better alignment. The nine motifs typical of DEAD-box RNA helicases $(10,11)$ are highlighted. The single arrows indicate other individual amino acids which seems to be relevant for elF4A function or RNA binding (12,42). Relevant GenBank accession numbers: LmEIF4AI, AAC24684/AAC24685; LmEIF4AIII, CAJ05468; TbEIF4AI, EAN76544; TbEIF4AIII, EAN79829; TcEIF4AI, EAN98527; TcEIF4AIII, EAN88971.

eIF4A-GSGSGPREQKLISEEDLPREQKLISEEDLPREQKLISEEDLPR.

Parasite growth, transfection and RNAi

Procyclic form T. bruce i Lister 427 cells were used throughout. RNAi and ectopic expression of elF4A were performed using T.brucei Lister 427 29-13, containing integrated copies of pLEW 29 and pLEW13 (34). Procyclic T.brucei forms were propagated in SDM- 79 medium at $27^{\circ} \mathrm{C}$, supplemented with $10 \%$ feotal calf serum (FCS). For the 29-13 cell line, cultures were also supplemented with G418 $(15 \mu \mathrm{g} / \mathrm{ml})$ and hygromycin $(25 \mu \mathrm{g} / \mathrm{ml})$. Parasite growth was monitored microscopically every $24 \mathrm{~h}$. Mid-log phase cultures $\left(10^{6}-\right.$ $10^{7}$ cells $/ \mathrm{ml}$ ) were then used for transfection and total protein extract production. Bloodstream forms (Lister 427) were cultivated in HMI-9 medium (37) at $37^{\circ} \mathrm{C}, 5 \% \mathrm{CO}_{2}$, supplemented with $10 \%$ FCS. Cultures grown to mid-log phase cultures $\left(10^{5}-10^{6}\right.$ cells/ml) were also harvested for the production of total protein extract.

Plasmids were linearized with NotI prior to electroporation and stable DNA integration was selected using phleomycin $(2.5 \mu \mathrm{g} / \mathrm{ml})$. For the RNAi experiments $1 \mu \mathrm{g} / \mathrm{ml}$ of tetracycline was added to mid-log phase cultures of transfected cells.

\section{RNA analysis}

RNA extraction and Northern blots were performed using standard methods $(38,39)$. DNA fragments containing complete ORFs were used as probes for TbEIF4As and EP procyclin. A genomic repeat containing both $\alpha$ - and $\beta$-tubulin genes was used to detect tubulin mRNA.

Recombinant protein expression, antibody production and western blots

His-tagged TbEIF4AI and TbEIF4AIII were expressed in Escherichia coli BL21 Star (DE3) using pET15b derived plasmids. The recombinant polypeptides were insoluble after lysing the cells using a French Press. The polypeptides were purified by preparative SDS-PAGE and the bands corresponding to the recombinant proteins were then excised and sent for the production of polyclonal serum (CovalAb). Prior to their use, both antibodies were first affinity purified as described elsewhere (40) with their respective recombinant proteins. Cross-reacting antibodies were eliminated by previous incubation of the anti-TbEIF4AI antisera with TbEIF4AIII recombinant protein and vice versa. To estimate the levels of the eIF4A proteins, first the recombinant proteins were quantified by serial dilutions in SDS-PAGE by comparison 
with known concentrations of BSA (data not shown). After quantification they were then used in western blots with the respective antisera and compared with serial dilutions of total protein extract from both procyclic and bloodstream forms of T.brucei. The endogenous protein levels were then estimated by the densitometric analysis of the western blot results as described elsewhere (33).

\section{Fluorescence microscopy}

For the indirect immunofluorescence assay, wild-type procyclic cells grown to mid-log phase $\left(5 \times 10^{6} / \mathrm{ml}\right)$ were harvested, washed with phosphate-buffered saline (PBS) $/ 10 \mathrm{mM}$ glucose and adsorbed to polylysine coated slides. The cells were then fixed in $100 \%$ methanol at $-20^{\circ} \mathrm{C} / 15 \mathrm{~min}$. Antibody detection of $T b$ EIF4AI and III followed standard procedures. DNA was stained using Hoechst 33258 . For the analysis of the cells expressing $T b$ EIF4AI-EYFP and TbEIF4AIII-EYFP, aliquots of $5 \times 10^{6}$ cells were harvested, washed with PBS/10 $\mathrm{mM}$ glucose and fixed in $0.1 \%$ formaldehyde for $5 \mathrm{~min}$. In this case, DNA was stained using Hoechst 33342.

\section{Metabolic labelling}

To measure the rate of protein synthesis, $\left[{ }^{35} \mathrm{~S}\right]$ methionine $(10 \mu \mathrm{Ci} / \mathrm{ml})$ was added to mid-log cultures which were incubated for $1 \mathrm{~h}$ prior to the determination of trichloroacetic acid precipitable incorporation into protein. Parallel incubations in the presence of $50 \mu \mathrm{g} / \mathrm{ml}$ cycloheximide were used to estimate incorporation of radiolabel by processes other than cytoplasmic protein synthesis. For metabolic labeling, cultures were washed twice with methionine-free RPMI 1640 medium and then resuspended at $1 \times 10^{7}$ cells $/ \mathrm{ml}$ in methionine-free RPMI 1640 containing $\left.50 \mu \mathrm{Ci} / \mathrm{ml} \mathrm{[}{ }^{35} \mathrm{~S}\right]$ methionine and incubated for $1 \mathrm{~h}$ at $28^{\circ} \mathrm{C}$ prior to harvesting and analysis by SDS-PAGE and autoradiography.

\section{RESULTS}

\section{Identification of the T.brucei eIF4A homologues}

The T.brucei homologues of eIF4A were identified in searches of the genome sequence using human eIF4AI as well as the two Leishmania eIF4A sequences. At the amino acid level, the two Thrucei proteins, TbEIF4AI and TbEIF4AIII, are very similar to their L.major orthologues with identities of $88 \%$ for the eIF4AI and $82 \%$ for the eIF4AIII pair (to avoid confusion and in view of the data presented below the L.major eIF4A homologues, previously called $L m E I F 4 A 1$ and 2, have also been renamed to $L m E I F 4 A I$ and $L m E I F 4 A I I I$ and this nomenclature will be used when needed). The assignment as eIF4A homologues reflects the fact that the two sequences are the closest matches in the two parasite protein databases to human eIF4AI and both share identities of over $50 \%$ with the human protein. The third nearest eIF4A homologue in both T. brucei and L. major databases has been assigned to another group of RNA helicases, Dhhl (33), with an identity of only $\sim 40 \%$ to human eIF4AI. In order to analyse the conservation of the putative eIF4A homologues within an additional member of the family Trypanosomatidae, we performed similar searches using the T.cruzi genome database. Again, orthologues to both proteins could be found in T.cruzi with the third nearest match to human eIF4AI being Dhhl

Figure 1 shows a sequence alignment comparing the two eIF4A sequences from T.brucei with those from T.cruzi and L.major. Highlighted in the figure are the various conserved motifs typical of eIF4A and related proteins which have been shown to be required for different aspects of the RNA helicase activity. Motifs I, II, VI and the recently identified Q motif (41) have been implicated in ATP binding and hydrolysis; motif III may link nucleotide hydrolysis to helicase function; motifs Ia, $\mathrm{Ib}$, IV and V may be involved in RNA binding [reviewed in $(11,14)]$. Several conserved arginine residues, which have also been implicated as important for eIF4A/helicase function in yeast eIF4A (12), as well as a conserved $\mathrm{N}$-terminal phenylalanine residue are also shown (42). Overall the alignment confirms the close similarity between the various homologues. In general the $\mathrm{N}$-terminal half of the protein is less conserved than the $\mathrm{C}$-terminal half but only in the very $\mathrm{N}$-terminus are significant differences in the sequences observed. A few conserved differences between the three eIF4AI and three eIF4AIII homologues with potential significance for their function can be identified, such as the replacement of a conserved F46 E47 doublet within the Q motif of eIF4AI by YK in eIF4AIII proteins. Other individual substitutions conserved between the eIF4AI and eIF4AIII homologues can be seen within motifs Q (S50T, S51A), I (Q71S), IV (A275C), V $(\mathrm{V} 328 \mathrm{~W})$ and VI (G359T). So far however the functional significance of these substitutions is unknown.

\section{Expression of $T b$ EIF4A mRNAs in $T$.bruce $i$ bloodstream \\ and procyclic forms}

To begin the functional characterization of T.brucei eIF4A homologues and assay their expression at the mRNA level, the two genes were amplified, cloned and used as probes in northem blots of RNA from Thrucei procyclic and bloodstream forms (Figure 2A). The membranes were also probed for the constitutively expressed tubulin, to confirm that equal amounts of mRNA were loaded in each lane, and for the procyclic-specific EP procyclin mRNA to verify the stage specificity of both sets of mRNAs (43).

The two T.brucei eIF4A mRNAs were readily detected and found to be at constant levels throughout the parasite life cycle. However, according to the northern blot, the TbEIF4AI mRNA produces a much stronger signal than TbEIF4AIII. Since both probes used were of similar specific activity, and the exposures times for the films were similar as well, it seems that the TbEIF4AIII mRNA is far less abundant than TbEIF4AI. Remarkably, although the ORFs for both proteins are similar, 1215 versus 1206 bp for TbEIF4AI and TbEIF4AIII, respectively, their mRNAs differ significantly, with the TbEIF4AI message, at $\sim 3 \mathrm{~kb}$, being nearly twice the length of $T b E \mathrm{E}-$ F4AIII $(\sim 1.6 \mathrm{~kb})$, probably reflecting a considerable difference in the length of the $3^{\prime}$-UTR.

\section{$T b$ EIF4AI is about 10 -fold more abundant than}

\section{$T b$ EIF4AIII in both procyclic and bloodstream forms}

Recombinant His-TbEIF4AI and III were expressed in E.coli, purified from inclusion bodies and used to produce antisera. Affinity purification and depletion was used to produce specific antibodies for each protein (see below, Figure 6A). The 
A

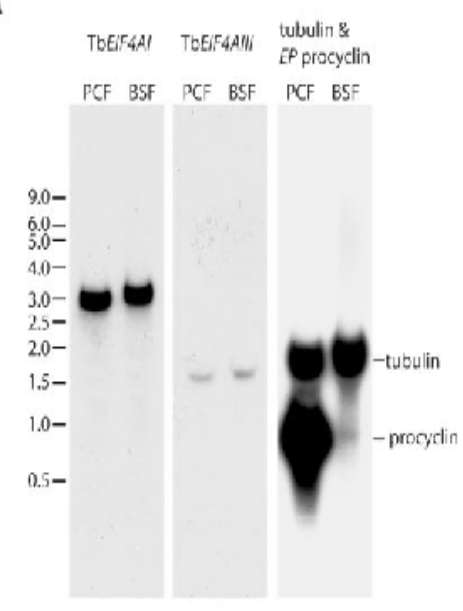

B

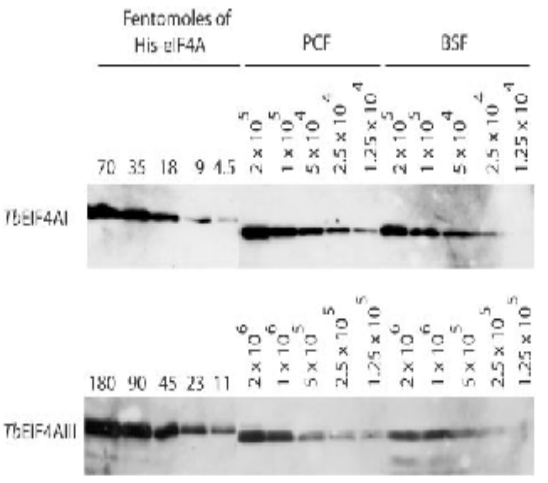

Figure 2. Expression analysis of $T b$ EIF4AI and III. (A) Total RNA from both procyclic (PCF) and bloodstream (BSF) T brucei forms was separated on denaturing gels and used in northern blot assays to detect the expression of naturing gels and used in northern blot assays to detect the expression of
TbEIF4AI and III. One of the blots was overprobed with tubulin (ubiquitously expressed) and EP procyclin (expressed in procyclics only) as controls. The migration of RNA size markers is indicated on the left in kilobases. (B) Quantification of $T b$ EIF 4AI and $T b$ EIF4AIII in the procyclic and bloodstream forms of $T$.brucei. Recombinant His-tagged TbEIF4AI and III were quantified, diluted to defined concentrations (in fmol) and ran on SDS-PAGE gels with whole puraste extract obtuined from known number of cells fom both procydicand paraste extract TbEIF4AIII). The proteins samples were then transferred to Immobilon-P TbEIF4AIII). The proteins samples were then transferred to Immobilon-P
membranes followed by incubation with the affinity purified isoform specific antisera and goat anti-rabbit $\operatorname{Ig} G$ conjugated with peroxidase, and detection by ECL. The values obtained for the abundance of the two proteins in fentomoles' $10^{3}$ or $10^{6}$ cells were then converted in number of molecules/cell.

antibodies were then used in western blots to analyse the expression of both proteins as well as to estimate their intracellular levels. TbEIF4AI is very abundant (Figure $2 \mathrm{~B}$ ) and although the quantification is only approximate, its levels were estimated at $\sim 2-5 \times 10^{5}$ and $0.8-1.5 \times 10^{5}$ molecules/cell in procyclic and bloodstream forms, respectively, this difference being a reflection of the relative volumes of the two cell types. These levels are compatible with what has been observed with the L.major orthologue (33) as well as yeast eIF4A (44). In contrast, TbEIF4AIII levels were estimated at $\sim 2 \times 10^{4}$ and $1 \times 10^{4}$ molecules/cell in procyclic and bloodstream forms, respectively (Figure $2 \mathrm{~B}$ ). These data indicate that TbEIF4AI is present at levels at least 10-fold higher than TbEIF4AIII, a difference which is reminiscent of the situation with the L.major orthologues (33). Since there are estimated to be $\sim 50000$ mRNAs per procyclic cell (Supplementary Data), $T b$ EIF4AI is in excess relative to mRNA, in contrast to $T b$ EIF4AIII. Overall we conclude that both proteins are expressed constitutively and that only the TbEIF4AI levels are compatible with a role in translation.

\section{Subcellular localization of $T b$ EIF4AI and III}

To determine the subcellular localization of the T.brucei eIF4A homologues we used two different experimental approaches. First the $T b$ EIF4AI and TbEIF4AIII ORFs were cloned into the vector p2215 and the construct integrated into the non-transcribed spacer of a ribosomal RNA gene locus in the procyclic cell line Lister 427 29-13. This resulted in a tetracycline-inducible transgene encoding the eIF4A fused at the C-terminus to EYFP. Expression of both constructs was first verified by western blotting and similar levels of expression were observed for both TbEIF4AI and III-EYFP fusion proteins (data not shown). The fluorescent proteins were visualized by microscopy (Figure 3) and strikingly, the two proteins localize differentially within cells. TbEIF4AI-EYFP is found predominantly in the cytoplasm, whilst TbEIF4AIII-EYFP is only found in the nucleus. These results were confirmed for the endogenous proteins through indirect immunofluorescence using isoform specific antibodies: again TbEIF4AI was mainly found in the cytoplasm whilst TbEIF4AIII was only detected in the nucleus (Figure 3).

\section{RNAi of TbEIF4AI and TbEIF4AIII}

The function of the two eIF4A homologues was then investigated by knock down of expression through RNA interference. First, both ORFs were subcloned into the vector $\mathrm{p} 2 \mathrm{~T} 7-177$ vector (35) and the constructs integrated into the procyclic cell line Lister $42729-13$ resulting in cell lines with tetracycline-inducible expression of double-stranded RNA.

Cell proliferation was reduced within $24 \mathrm{~h}$ and ceased around $48 \mathrm{~h}$ after induction of TbEIF4AI RNAi (Figure 4A) and the cell density increased by $\sim 3$-fold during this time. Western blotting over a time course after addition of tetracycline showed that the level of the protein decreased to $<10 \%$ of the starting level but expression was not completely ablated (Figure 4B). Protein synthesis after induction of TbEIF4AI RNAi was monitored in two ways: (i) metabolic labelling to identify any alterations in the complement of polypeptides synthesized, and (ii) the rate of total protein synthesis was measured. There were no substantial changes in the profile of proteins synthesized although a small number of polypeptides appear to be relatively less affected by $T b$ EIF4AI depletion. The overall rate of protein synthesis had halved by $\sim 22 \mathrm{~h}$, the time at which cell proliferation ceased and was reduced to $<20 \%$ of the uninduced control by $48 \mathrm{~h}$ as shown in Figure $4 \mathrm{C}$. 


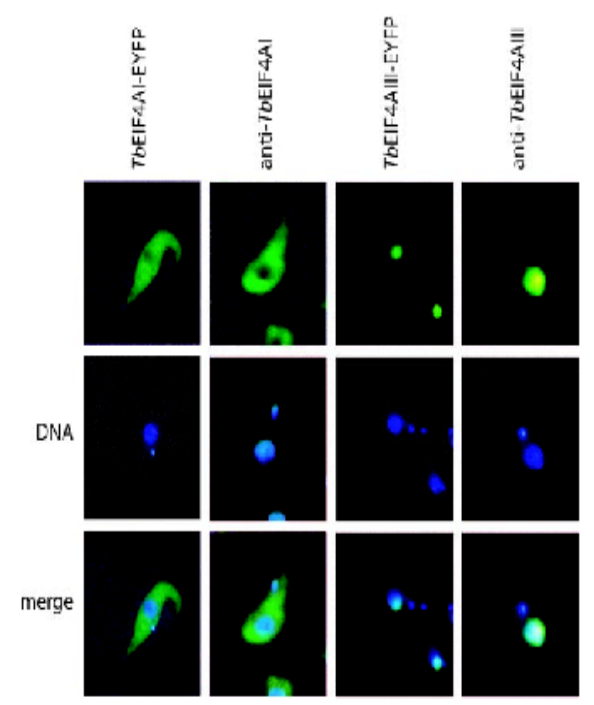

Figure 3. Subcellular localization of TbEIF4AI and III in T.bruce procyclic forms. Subcellular localization of the TbEIF4AI and III/EYFP fusion proteins in transfected $T$. bricei cells was examined with afluorescence microscope. The localization of native $T b$ EIF4AI and III was also confimed in wild-type procyclic cells (WT 427) by indirect immunofluorescence using the TbEIF4AI or $T b$ EIF4AIII specific antibodies followed by incubation with the fluoresceinconjugated secondary ant ibody. Where indicated, the cells were counterstained to locate the nuclear and kinetoplast DNA. Note lack of TbEIF4AIII staining of the kinetoplast.

The phenotype of cells after RNAi ablation of TbEIF4AIII was different. These cells only showed a dramatic reduction in the rate of proliferation 3 days after induction of RNAi, during which time the cell density increased $\sim 20$-fold (Figure $5 \mathrm{~A}$ ). Levels of $T b$ EIF4AIII fell dramatically during the first $24 \mathrm{~h}$ of RNAi (Figure 5B), and the protein was only just detectable in extracts derived from cells at the $48 \mathrm{~h}$ time point. It is possible that, owing to its low abundance even in wild-type cells, residuals levels of TbEIF4AIII persist longer than $48 \mathrm{~h}$ in the cells after RNAi although they are not detected by the western blotting assay. These residual levels would be responsible for the delayed onset of the growth phenotype. The western blotting results also confirm that lack of TbEIF4AIII is not involved in the phenotype induced by the depletion of TbEIF4AI since no reduction in levels of TbEIF4AIII was observed in cells submitted to the TbEIF4AI RNAi procedure (Figure 5B). Likewise the TbEIF4AIII RNAi does not lead to any reduction in the levels of $T b$ EIF4AI (Figure 4B). These results are compatible with $T b$ EIF4AIII being required only at very low levels so that many cell cycles are required after addition of tetracycline to impair cell growth. In contrast, the levels of TbEIF4AI, despite its abundance in wild-type cells, are much more sensitive to RNAi mediated depletion, consistent with a role in overall protein synthesis.

\section{Expression of dominant negative mutants of TbEIF4AI} and III in transfected procyclic cells

The helicase activity of eIF4A is essential for protein synthesis and viability and some mutations that abolish its activity can

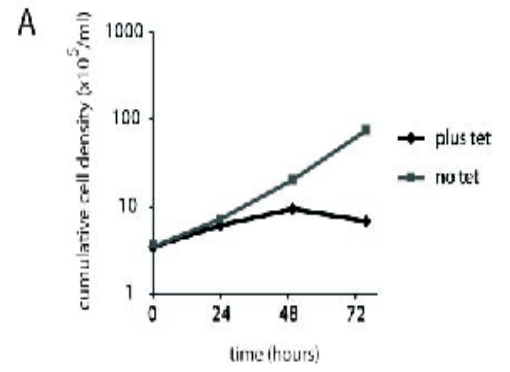

B
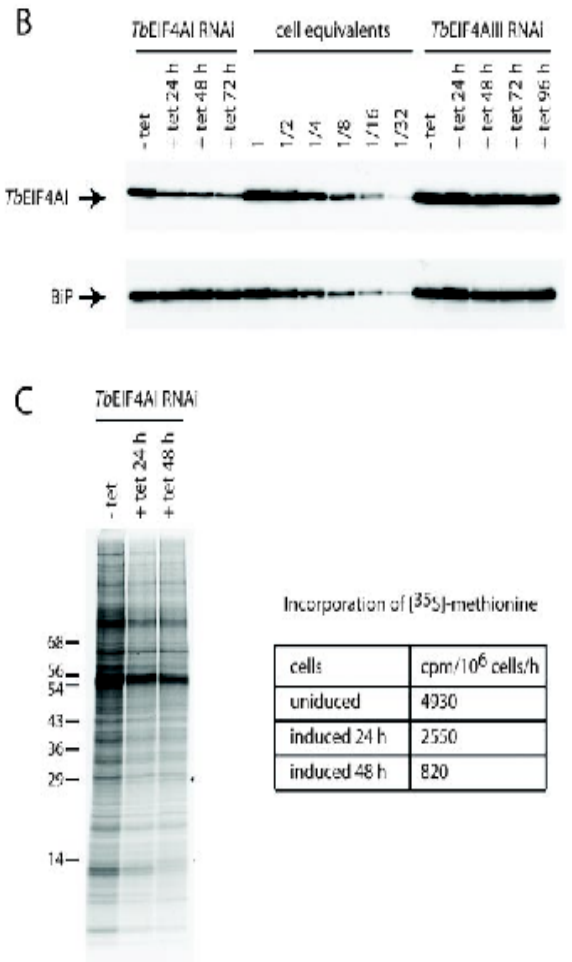

Figure 4. RNAi of TbEIF4AI. Procyclic T.brucei cells were transfected with the p2T7-177 derived plasmid containing the TbEIF 4AI gene. Transfected cells were selected after growth in the presence of phl eomycin and RNA interference induced after tetracycline addition. At regular intervals, cellular growth was monitored by counting the number of viable cells, expression of $T b E I F 4 A$ asa

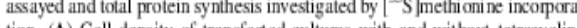
tion. (A) Cell density of transfeded cultures with and without tetracycline addition. (B) Western blot analysis of the time course. Note the various dil ution of total cell extract for comparison (1-1/32 cell equivalent-1 cell equivalen equals to $10^{6}$ cells and was used in the various RNAi lanes). TbEIF4AI was detected with the affinity purified antisera and anti-BiP was used as a loading control. The same blot was probed with both antibodies. Equivalent extracts of cells transfected with the p2T7-177/TbEIF4AIII construct (see also Figure 5)

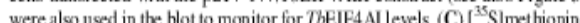
were als ind ine b] methonine incorporation profle in farleded cels grown without tetracycline or 24 and $48 \mathrm{~h}$ after its addition. Total protein synthesis was estimated after RNA for $T b$ EIF4AI by incubating aliquots of the cells in the presence of $\left[{ }^{35} S\right]$ methionine for $1 \mathrm{~h}$ followed by TCA precipitation, quantitation of the incorporated radioactivity or SDS-PAGE followed by autoradiography of the selected samples. 
A

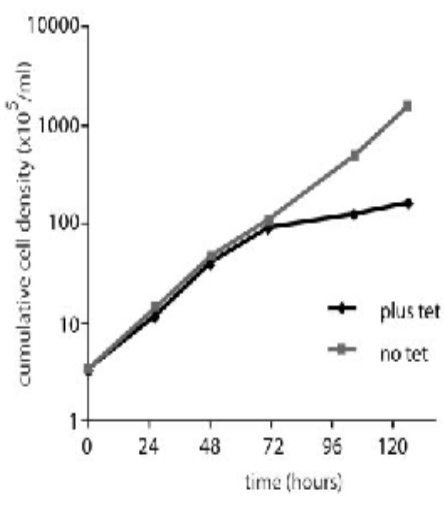

B

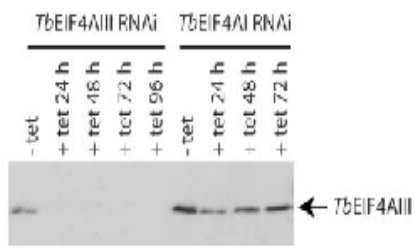

Figure 5. RNAi of TbEIF4AIII. Procyclic $T$. brucei cells were transfected with the p2T7-177/ TbEIF4AIII construct as described for Figure 4, monitored for cellular growth and assayed for expression of TbEIF4AIII. (A) Cell density of transfected cultures at different time points with and without tetracycline addition. (B) Western blot analysis of the time course for both the TbEIF4AIII and TbEIF4AI RNAi experiments using the TbEIF4AIII antibodies. Samples from the same experiment assayed in Figure 4B were assayed for TbEIF4AIII expression.

act as dominant negative mutants. Wild-type Thrucei helicases and equivalent DEAD-box mutant transgenes, in which the glutamic acid residue in the DEAD motif II (Figure 1) was substituted with a glutamine (DEAD $\rightarrow$ DQAD), DQAD), were expressed using a tetracycline-inducible promoter. This mutation induces a dominant negative phenotype in mammalian eIF4AI, resulting in potent inhibition of protein synthesis and is widely used to abrogate the function of DEAD-box proteins $(11,36)$. The transgenes encoded a C-terminal triple myc tag to distinguish the expression of the transgene from the endogenous protein. Wild-type and mutant versions of the two proteins were then expressed in procyclic Lister 42729 -13 cells and analysed by western blotting (Figure 6). The tetracycline regulation of expression was effective and the wild type and mutant proteins were expressed at similar levels (Figure 6A). The level of expression relative to the endogenous protein varied; the expression from the TbEIF4AI transgenes was lower than expression from the endogenous gene whereas expression from the TbEIF4AIII transgenes was several fold higher than the endogenous protein. All the myc-tagged transgenes localized correctly (data not shown).
Cell growth and transgene expression was monitored over a time course (Figure 6B). Expression from the TbEIF4AI transgene reduced over the time course and was barely detectable by $104 \mathrm{~h}$. We have observed this diminution of expression over time with other, but not all, transgenes expressed from vectors derived from pLEW100 and are unsure of the cause. The only transgene that had any effect on growth was the mutant form of TbEIF4AI (Figure 6C), all others grew at the same rates as the control cultures without tetracycline (data not shown). At 18-51 h after the addition of tetracycline, the expression levels of the TbEIF4AI transgenes were readily detectable and the mutant, but not the wild type, produced a slowing of growth. As the expression of the transgene reduced, the culture retumed to the same rate of growth as the no tetracycline control. In contrast, the significantly overexpressed TbEIF4AIII mutant transgene had no effect on growth of the culture. Interestingly, the expression of the TbEIF4AIII transgenes, but not the TbEIF4AI transgenes, resulted in increased levels of the endogenous protein. Overall, the results are compatible with the RNA helicase activity of TbEIF4AI being strictly required for growth. As for TbEIF4AIII, the lack of a slow growth phenotype when the dominant negative mutant is expressed suggests that either its RNA helicase activity is not required for the protein function or it is not affected by the $\mathrm{DEAD} \rightarrow \mathrm{DQAD}$ mutation. Either option strongly indicates that $T b$ EIF4AIII is not active in translation.

\section{Mapping of isoform specific amino acids}

The results described above for TbEIF4AIII are reminiscent of what is known of mammalian eIF4AIII (Discussion). Human eIF4AIII, identified previously as a negative regulator of translation (22), has been shown to be a component of the EJC, with roles in mRNA export, cytoplasmic RNA localization and NMD (24-27). Pairwise sequence comparisons between $T b$ EIF4AI and III (or their orthologues in T.cruzi and L.major) and the functionally divergent human eIF4AI/eIF4AIII do not show a clear match between either of the parasite homologues with the two human sequences. Indeed, the overall identity between human eIF4AI/eIF4AIII $(66 \%)$ is greater than that between either protein and the two trypanosomatid eIF4As $(\sim 55-60 \%)$.

The kinetoplastide IF4AI and eIF4AIII sequences were then aligned with putative eIF4AI and eIF4AIII homologues from the major lines of eukaryotic evolution (Figure 7). The homologues from Arabidopsis thaliana and Schizosaccharomyces pombe were identified using BLAST searches of nonredundant sequence databases using the human eIF4AI or eIF4AIII sequences as queries. The alignment in Figure 7 does not show any continuous sequence of amino acids that distinguish between all putative eIF4AI or eIF4AIII homologues. However, at various positions, interspersed within the sequences common to both sets of proteins, individual amino acids can be identified which are conserved and unique either to the eIF4AI or eIF4AIII proteins. Table 1 lists 13 positions where a clear difference could be found between the two sets of sequences. Several, but not all, of these amino acid substitutions are also shared by an eIF4AIII-related protein from Saccharomyces cerevisae, Fallp, a nucleolar protein shown to be required for $40 \mathrm{~S}$ ribosomal subunit formation (45). Fallp, however, does not seem to be involved in EJC 


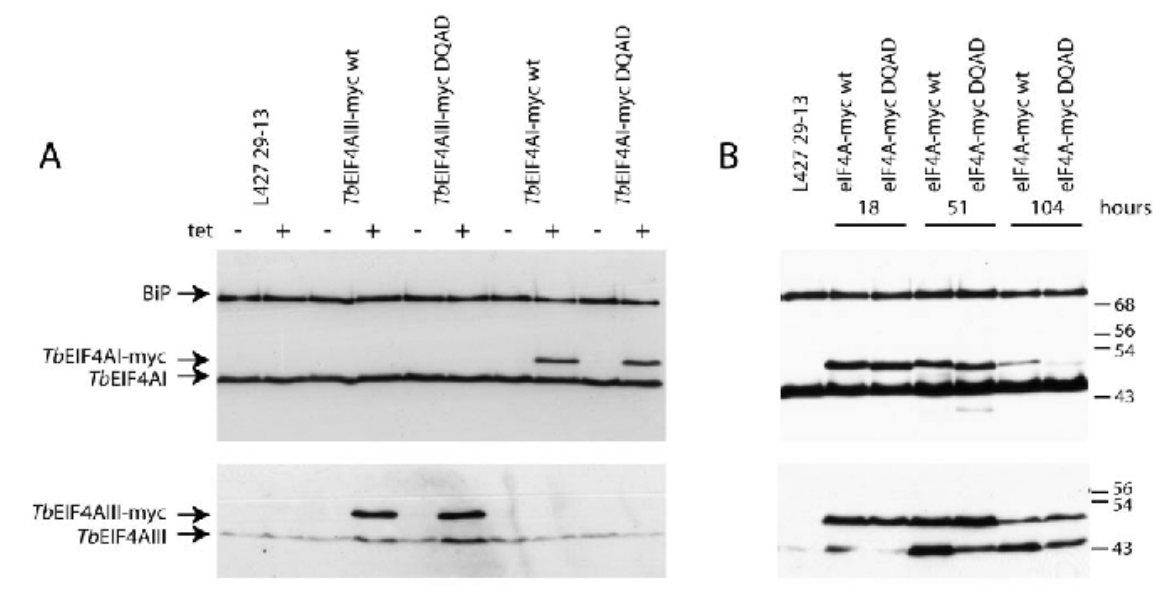

C

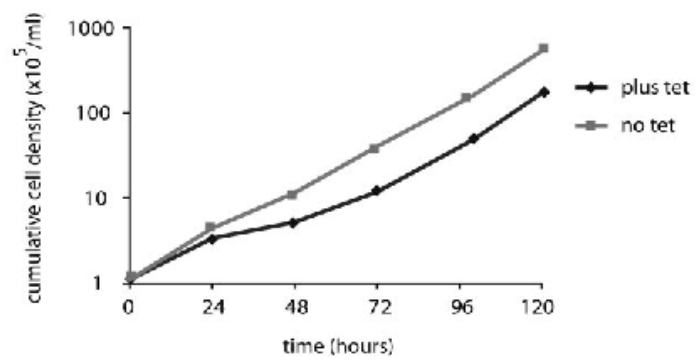

Figure 6. Expression of myc-tag ged dominant negative mut ants of TbEIF4AI and III in procyclic cells. (A) Western blot analysis of the expression of the various $T b$ EIF $4 \mathrm{AI}$ and III/mye fusions in transfected cells in the absence or after exposure to tetracycline for $18 \mathrm{~h}$. In each case the expression was detected using antibodic spectice to cachof the el tA

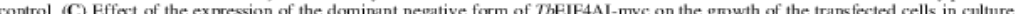

formation since a search in S.cerevisae for similar EJC constituents, conserved in other fungi and in plants, such as Magoh or Y14, did not produce any clear homologues.

The various amino acid substitutions listed in Table 1 (TbEIF4A I numbering), indicated by a star in the alignment in Figure 7, discriminate between all putative eIF4AI and eIF4AIII homologues compared, including the two trypanosomatid proteins. These substitutions are located in the two globular domains present in eIF4A and related DEAD-box helicases $(11,14)$. Both the $\mathrm{N}$ - and the C-terminal domains have been shown to participate in the binding to RNA and ATP required for the helicase/ATPase activities, but few roles have been postulated for them regarding specific protein functions. The alignment results clearly show that candidate eIF4AII homologues are present throughout the various elFaryotic lineages, although it has only been function enkaryotic lineages, although it has only been functionally characterized in metazoans. The unique substitutions are
also indicative of amino acids involved in specific aspects of eIF4AI/III function in general (see below).

\section{Molecular modelling of TbEIF4AI and TbEIF4AIII}

To understand the functional implications of the observed amino acids substitutions to eIF4A function, not only in 


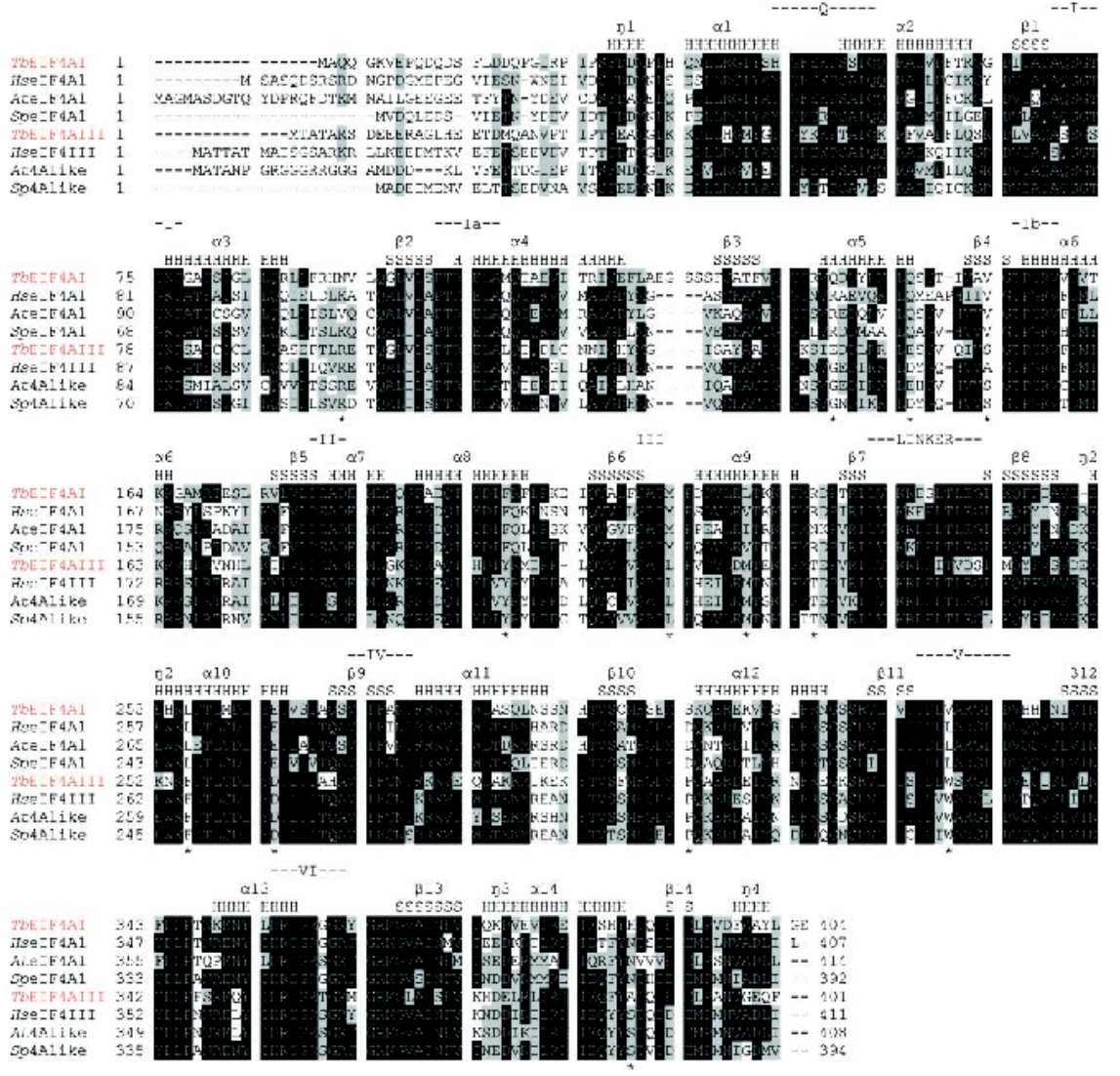

Figure 7. Sequence alignment comparing $\mathrm{TbEIF} 4 \mathrm{AI}$ and III with the putative elF4AI and eIF4AIII from selected organisms. (A) Sequences werealigned as described in Figure 1 and the various DEAD Figure 8 and from Ref. (46) are indicated numbered $\alpha 1-\alpha 13 / \eta 1-\eta$ (alpha-helices- $-\mathrm{H}$ ) and $\beta 1-\beta 14$ (beta-strands-S). Asterisk indicates amino acids which distinguish between the elF4AI and elF4AIII homologues. Further relevant GenBank accession numbers: human $(H s)$ elF4AI, AAX43035; human elf4AII (Hself4A3), P38919; S ponbe (Sp) elf 4A1, CAA56772; S.pambe elF4A-like protein (Sp4Alike), CAA92238; A.thaliana (At) elf4A1, NP_177417; A.thaliana

trypanosomatids but also in eukaryotes in general, we modeled the structures of both TbEIF4AI and III based on the solved structure of either the yeast S.cerevisae elF4A (12) or the related DEAD-box protein Dhhlp (46) The structure of yeast elF4A is in an domins positioned apan and non-interating. In col domip is in a facing each other. Most of the conserved motifs in Dhhlp are positioned in close spatial proximity facing the cleft between the two domains. Both sets of models were validated as described (33) and found to have self-consistency in terms of sequence-structure compatibility and to be of good overall quality. For our analysis we favored the closed conformation structure since the two domains need to interact in order to fully form the ATP- and RNA-binding sites $(12,46,47)$.

Figure $8 \mathrm{~A}$ shows the ribbon drawing for the predicted structures of $T b$ EIF4AI and TbEIF4AIII. Highlighted in the figure are several of the diagnostic amino acid substitutions identified in the eIF4A alignment (Figure 7). Of special interest is the $\mathrm{V} / \mathrm{L} 328 \mathrm{~W}$ substitution in motif $\mathrm{V}$, in the C-terminal domain. 
Table 1. Summary of the amino acid substitutions identified between the putative elF4AI/eIF4AIII homologues from the main lineages of eukaryotic evolutio

\begin{tabular}{|c|c|c|c|c|}
\hline Position: TbEIFAI & Substitution: $4 \mathrm{AI}>4 \mathrm{AIII}$ & Secondary structure & Domain & Overall position in predicted tertiary structure \\
\hline 93 & $\mathrm{~K} / \mathrm{N} / \mathrm{V}>\mathrm{R}$ & Loop & $\mathrm{N}$-terminal & Near $\alpha 5 /$ exposed \\
\hline 139 & $\mathrm{Q} / \mathrm{R}>\mathrm{E} / \mathrm{G}$ & $\alpha 5^{\circ}$ & $\mathrm{N}$-terminal & Exposed \\
\hline 146 & $\mathrm{Q} / \mathrm{A}>\mathrm{E} / \mathrm{D}$ & $\alpha 5$ & $\mathrm{~N}$-teminal & Exposed \\
\hline 153 & $\mathrm{~V}>\mathrm{S} / \mathrm{A}^{2}$ & $\beta 4$ & $\mathrm{~N}$-terminal & Buried \\
\hline 197 & $\mathrm{~F}>\mathrm{Y}$ & $\alpha 8$ & $\mathrm{~N}$-terminal & Partially exposed \\
\hline 213 & $M>L$ & Loop & $\mathrm{N}$-terminal & Interface/next to Motif III/partially buried \\
\hline 220 & $\mathrm{~L} / \mathrm{V} / \mathrm{I}>\mathrm{M}$ & $\alpha 9$ & $\mathrm{~N}$-terminal & Buried \\
\hline 226 & $\mathrm{R} / \mathrm{N}>\mathrm{T}$ & Loop & C-terminal & Exposed \\
\hline 256 & $\mathrm{~L}>\mathrm{F}^{a}$ & $\alpha 10$ & C-terminal & Partially buried \\
\hline 264 & $\mathrm{E}>\mathrm{D}^{a}$ & $\alpha 10$ & C-terminal & Exposed \\
\hline 303 & $\mathrm{~S} / \mathrm{D}>\mathrm{P}^{\mathrm{a}}$ & Loop & C-terminal & Exposed \\
\hline 328 & $\mathrm{~V} / \mathrm{L}>\mathrm{W}^{a}$ & Loop & C-terminal & Interface/Motif V/Buried \\
\hline 388 & $\mathrm{H} / \mathrm{N}>\mathrm{A} / \mathrm{S}^{\mathrm{a}}$ & Loop & C-terminal & Exposed \\
\hline
\end{tabular}

aThese substitutions but not the others are present in the S.cerevisae nucleolar protein Fal lp [may be related to the elf 4AIII proteins (45)]

Motif V lies in a loop positioned in the interface between the two domains and, in Dhhlp, several amino acids in this moti are seen to make direct interactions with specific amino acids in motifs I and Q, positioned in the N-terminal domain (46). In the models shown here both the $\mathrm{V}$ and $\mathrm{W}$ residues in $T b E I F 4 \mathrm{AI}$ and III, respectively, are protruding from the main polypeptide backbone in the direction of a cleft in the proteins' $N$-terminal domain. To investigate the likelihood of either amino acid interacting with neighboring chains, atoms in these chains were first identified which are positioned within a radius of $4 \AA$ from the two residues. These are the only ones capable of forming non-covalent interactions to atoms in either amino acid and the full set of potential interactions are shown in Figure 8B as dotted lines. The substantially larger $\mathrm{W}$ residue in TbEIF4AIII is capable of making a number of interactions with neighboring amino acids in both the $\mathrm{N}$ - and $\mathrm{C}$-termina 政 trast, the $\mathrm{V}$ residue in TbEIF4AI is very limited in the number of interactions it can establish. It is possible then that the presence of the W residue in TbEIF4AIII, and other eIF4AII homologues, can enhance the interaction between the helicase's two domains as compared to the $\mathrm{V} / \mathrm{L}$ residue in the $\mathrm{IF} 4 \mathrm{AI}$ and even Dhhlp proteins.

Other potentially interesting eIF4AIII-like substitutions map in helices $5(\mathrm{Q} / \mathrm{R} 139 \mathrm{E} / \mathrm{G}, \mathrm{Q} / \mathrm{A} 146 \mathrm{D} / \mathrm{E})$ and $10(\mathrm{~L} 256 \mathrm{~F}$, $\mathrm{E} 264 \mathrm{D}$ ), on the $\mathrm{N}$ - and C-terminal domains, respectively. These helices are largely exposed to the solvent on the external side of the proteins (Table 1) and thus the amino acids involved could mediate eIF4A binding to functional partners. Indeed, recent evidence strongly supports such a hypothesis. First, the binding surface for eIF4GII has been mapped to the C-terminal domain of eIF4AI (47). A double mutation in human eIF4AI which prevents binding to eIF4GII maps to helix 10 and targets the same glutamate residue (E264) found to be unique to the eIF4AI sequences. Likewise, the two substitutions in helix 5 are included within a proposed eIF4AIII specific mot if (motif $\mathrm{C}$ ) which has just been found to constitute part of the binding site for the EJC component MNL51 (30). Moreover, a further unique substitution identified in Figure 7, which lies in an exposed loop near the C-terminal end of the eIF4A proteins $(\mathrm{H} / \mathrm{N} 388 \mathrm{~A} / \mathrm{S}$-also shown in Figure 8), lies within another proposed motif (motif $\mathrm{H}$ ) found to be required for eIF4AIII to bind spliced mRNA and to rescue NMD in eIF4AIII depleted cells (30). In summary, we have identified several individual amino acids conserved in either eIF4AI or eIF4AIII sequences which may play significant roles in these proteins' functions not only in rypanosomatids but also in eukaryotes in general.

\section{DISCUSSION}

The results presented here provide strong support that only one of the two eIF4A homologues identified in trypanosomatids is involved in the initiation of translation. The abundance of the TbEIF4AI protein, its constitutive expression during the parasite life cycle as well as its cytoplasmic localization, the effect of RNAidepletion and the dominant negative phenotype of the $\mathrm{DEAD} \rightarrow$ DQAD mutation are all compatible with what is expected of this protein. In contrast, TbEIF4AII does not seem to play an obvious role in protein synthesis. The nuclear localization of TbEIF4AIII, its low abundance, longer response to the RNAi induced phenotype and lack of inhibition by the dominant negative mutant all indicate an essential role in RNA metabolism in the nucleus unrelated to eIF4A function in translation. These results are also compatible with what is known of the L.major orthologues; LmEIF4AI binds strongly to at least two eIF4G homologues whereas $L m E I F 4 A I I I$ has a reduced binding activity [(33) and C. R. S. Reis, unpublished datal. Mammalian eIF4AII localizes mainly to the nucleus (23), is present in levels $\sim 10$-fold lower than eIF4AI in HeLa cells and does not function in protein synthesis (22). An unusual feature of human eIF4AIII is that the DEAD $\rightarrow$ DQAD DQAD mutation has no effect on its activity in EJC formation and NMD (30). Thus, TbEIF4AIII behaves similarly to human eIF4AIII in several important aspects and, coupled with the sequence analysis data, our results are consistent with it being an eIF4AIII orthologue with functions possibly conserved along most major lines of eukaryotic organisms.

As part of the EJC, eIF4AIII binds directly to the core proteins Magoh, Y14 and MLN51 (25-30) and also to other proteins required for EJC function such as the TAP and Aly REF proteins involved in nuclear mRNA export (25). Magoh REF proteins involved in nuclear mRNA export (25). Magoh
homologues have been clearly identified in the three trypanosomatid genomes finished to date, Thuce (GenBan, AAZ12053), T.cruzi (EAN97132) and L.major (CAJ06870) and possible TAP homologues can also be found. We have also tried to identify candidate Y14, MLN51 or Aly/REF 
homologues but so far without success. However, both Y14 and Aly/REF are small RNA-binding proteins with sing RRMs, a category which includes many proteins with unassigned functions in those three genomes (48). It may

\section{A}
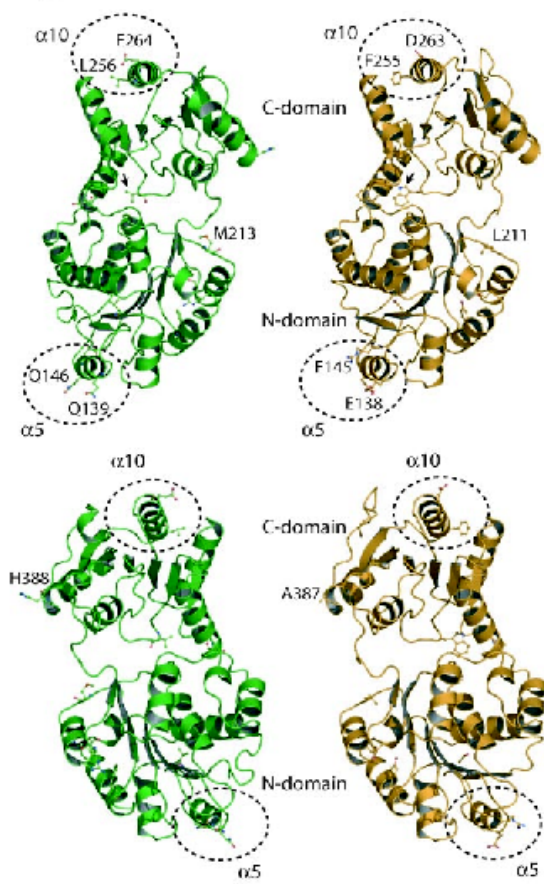

0.10

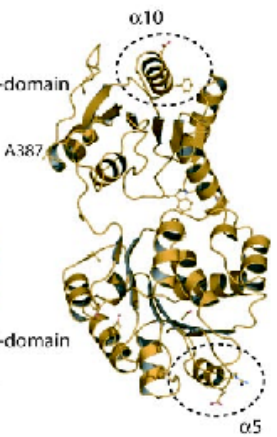

B

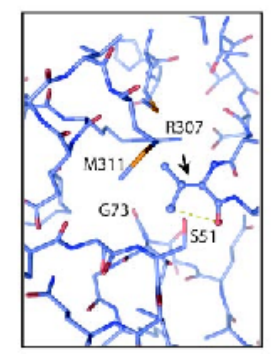

TbEIF4AI

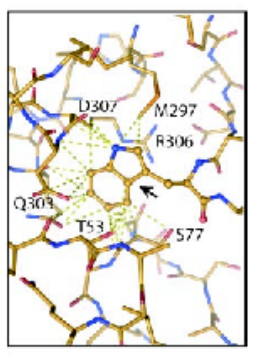

TbEIF4AIII be possible that, due to the degree of evolutionary distance between trypanosomatids and animals, homologues to these two proteins cannot be clearly identified by sequence analysis alone. As for MLN51 it is poorly conserved outside the metazoans so it is unlikely also for homologues to be identified in zoans so it is unlikely also for homologues to be identified in strong conservation of the Magoh sequences between the human and parasite homologues (over $50 \%$ identity) is an human and parasite homologues (over $50 \%$ identity) is an
indication that the EJC may be present throughout the major groups of eukaryotes and that eIF4AIII-like proteins may be active within this complex.

In a very recent study eight eIF4AIII specific motifs (named A to $\mathrm{H}$ ) were identified in an alignment comparing various eIF4AIII homologues with the human eIF4AI and II proteins. Selected amino acids in some of these motifs, as well as in the 作 recombinant or in wivo overexpressed elFAAll to investigate their requirement for eIF4AIII function (30). In the alignment provided here, which includes both T.brucei eIF4A homologues, as well as eIF4AI sequences from divergent organisms, no continuous set of amino acids were found to be typical of either eIF4AI or eIF4AIII proteins. However, unique amino acid substitutions were identified which distinguish eIF4AIIIlike proteins from eIF4AI homologues in all sequences investigated so far. Several of these substitutions not only coincide with some of the proposed eIF4AIII specific motifs (motifs C, W and $\mathrm{H}$ ), but also are included in two of those motifs found to be involved in specific eIF4AIII functions such as binding to be involved in specific elF4AII functions such as binding to the EJC partner MLN51 (motif C) and requirements for bind-
ing to spliced mRNA and for NMD (motif $\mathrm{H}$ ) (30). However ing to spliced mRNA and for NMD (motif $\mathrm{H}$ ) (30). However some of the unique eIF4AI/eIF4AIII substitutions identified here do not coincide with the remaining proposed motifs. These might be involved in mediating other aspects of eIF4A function and should be considered as targets for further investigation. Very few protein coding genes in trypanosomatids contains a cis-intron $(49,50)$. However, every cytoplasmic mRNA is trans-spliced to form the mature 5 end of the mRNA and this
splice site is possibly the location of EJC binding. The function of the EJC in these organisms remains obscure specially conof the EJC in these organisms remains obscure specially con-
sidering that the splice site is always to the $5^{\prime}$ side of the ORF. sidering that the splice site is always to the $5^{\prime}$ side of the ORF.
The EJC-mediated mechanism of NMD seems to be restricted The EJC-mediated mechanism of NMD seems to be restricted
to mammalian cells [reviewed in $(51,52)$ ] and indeed there is strong evidence that NMD does not occur in trypanosomatids (38). In mammals, both the EJC and the nuclear cap-binding complex (CBC, composed of two subunits CBP20 and CBP80)

Figure 8. Molecular modelling of TbEIF4AI and III highlighting the position of amino acids unique to the elF4AI or elf4AIII homologues. Diagrams were created with the program PyMol (ht tp://www.pymol.org). (A) Ribbon diagrams of the overall structure of both $T b$ EIF4AI and III viewed as in (46) (upper panel) or rotated $180^{\circ}$ about its long axis (lower panel). The structure is in a closed
conformation where the two, $\mathrm{N}$-andC-terminal, domains are facing each other. conformation where the two, $\mathrm{N}$-and $\mathrm{C}$-terminal, domains are facing each other.
The arrows indicate the position of the $\mathrm{L} .328 \mathrm{~W}$ substitution which lies in the loop The arrows indicate the position of the $\mathrm{L} 328 \mathrm{~W}$ substitution which lies in the loop
containing Motif $\mathrm{V}$ and is positioned in the interface between the two domains. The dotted circles delimit the two helices discussed in the text, $\alpha 5$ and $\alpha 10$. The $\mathrm{H} / \mathrm{N} 388 \mathrm{~A} / \mathrm{S}$ and $\mathrm{M} 213 \mathrm{~L}$ substitutions are also indicated (their numbering differ however from the elF4AV/eIF4AIII sequences-for instance, H388 in TbEIF4AI is equivalent to A387 in TbEIF4AIII and so on). (B) Balls andsticks representation showing the neighbourhood of the L328W substitution in both TbEIF4AI and III. The dotted lines indicate the atoms in the neighbouring amino acidchains which are positioned within a radius of $4 \hat{A}$ from the atoms in either 
bind to precursor mRNAs in the nucleus, prior to or during the splicing event, and remain bound to the mRNAs until they are transported to the cytoplasm and/or translated for the first time $(53,54)$. In $T$ brucei a novel $\mathrm{CBC}$ has been described which consists of a CBP20 subunit (also present in yeast and humans) plus four other polypeptides, one of which is importin- $\alpha$ (known to associate with CBC in other eukaryotes) and three novel proteins only present in trypanosomatids. The parasite $C B C$ has been implicated in the early steps of mRNA maturation, prior to the trans-splicing event whereas the polycistronic precursor mRNA is cleaved into mature monocistronic units (55). At this stage it still remains to be determined whether TbEIF4AIII and other components of the putative EJC are also necessary for mRNA processing, export from the nucleus or even translation in trypanosomatids.

\section{SUPPLEMENTARY DATA}

Supplementary Data are available at NAR Online.

\section{ACKNOWLEDGEMENTS}

We would like to thank M. Moore for sharing unpublished data and J. Bangs for the gift of the BiP antibody. O. Thiemann and D. Souza allowed us access to the computing facilities necessary for the modelling work. The work in Cambridge was funded by the Wellcome Trust and by a Nuffield Foundation summer studentship to $\mathrm{N}$. Marinsek. The Brazilian scientists were supported by grants/studentships from CNPq and CAPES. Funding for the laboratory in Recife came in part from a grant from $\mathrm{FACEPE} / \mathrm{CNPq} / \mathrm{CT}$ INFRA.

Conflict of interest statement. None declared.

\section{REFERENCES}

1. Campbell,D.A., Thomas,S. and Sturm,N.R. (2003) Transcription in kinetoplastid protozoa: why be normal? Microbes Infect., 5 , $1231-1240$

2. Liang,X.H., Haritan,A., Uliel,S. and Michaeli,S. (2003) trans and $c i s$ splicing in trypanosomatids: mechanism, factors, and regulation 3. Perry,K.L. Watkins,K.P. and Agabian,N. (1987) Trypanosome mRNAs
have unusual 'cap 4' structures acquired by addition of a spl iced leader. Proc. Natl Acad. Sci. USA, 84, 8190-8194.

4. Hershey,J.W.B. and Merrick,W.C. (2000) Patthway and mechanism of initiation of protein synthesis. In Sonenbery,N., Hershey,J.W.B. and Mathews,M.B. (eds), Translational Confrol Of Gene Expression. Cold Spring Harbor Laboratory Press, Cold Spring Harbor, NY, pp. 33-88. . Pestowa,T.V., Kolupaeva, V.G., Lomakin,I.B., Pilipenko,E.V., Shatsky,I.N., Agol, V.I. and Hellen,C.U. (2001) Molecular mechanisms of translatio

6. Preiss,T. and Hentze,M.W. (2003) Starting the protein synthesis

machine: eul.

7. Sonenberg,N. and Dever,T.E. (2003) Eukaryotic translation initiation

factors and regulators. Curr. Opin. Struct. Biol., 13, 56-63,

. Gingras,A.C., Raught,B. and Sonenberg,N. (1999) elf4 initiation

lactors: effectors of mRNA recruitment to nbosomes and regulators of translation. Ans. Ron Bhochem., 68, 913-963.

sequence comparisons and structure-function relationships. Curr. Opin.

10. Linder,P. (2003) Yeast RNA helicases of the DEAD-box family 11. Rocak,S. and Linder,P. (2004) DEAD-box proteins: the driving force
behind RNA metabolism. Nature Rev. Mol. Cell Bial., 5, 232-241. 2. Caruthers,J.M., Johnson,E.R. and McKay,D.B. (2000) Crystal structure of yeast initiation factor 4A, a DEAD-box RNA helicase. Proc. Narl Acad. Sci. USA, 97, 13080-13085.

3. Story,R.M., L,H. and Abelson,J.N. (2001) Crystal structure of a DEAD box protein from the hyperthemophile Me
Prac. Natl Acad. Sci. USA, 98, 1465-1470.

14. Carruther IM and McKay.DB. (2002) Helicase strocture and 4. Caruthers, J.M. and McKay, D.B. (2002) Helicase st
mechanism. Curr. Opin. Struct. Biol., 12, 123-133.

15. Marcotrigiano,J, Lomakin.I.B. Sonenberg, N., Pestova,TV. Hellen,C.U. and Burley,S.K. (2001) A conserved HEAT domain within elF4G directs assembly of the translation initiation machinery. Mol.

Cell, 7, 193-203.
16. Imataka,H. and Sonenbery,N. (1997) Human eukaryotic translation initiation factor $4 \mathrm{G}$ (elF4G) possesses two separate and independent

17. Yang,H.S., Cho,M.H., Zakowicz,H., Hegannyer,G., Sonenberg,N. and Colbum,N.H. (2004) A novel function of the MA-3 domains in binding to eukaryotic translation initiation factor 4A. Mol. Cell. Biol. 24, 3894-3906.

18. Svitkin,Y.V., Pause,A., Haghighat,A., Pyronnet,S., Witherell,G., Belsham, G.J. and Sonenberg,N. (2001) The requirement for eukaryotic initiation factor $4 \mathrm{~A}$ (elF4A) in translation is in direct proportion to the degree of mRNA $5^{\prime}$ secondary structure. RNA, 7, 382-394.

19. Pestova,T.V. and Kolupaeva,V.G. (2002) The roles of individual cukaryotic translation initiation factors in ribosomal sc

20. Nielsen,P.J. and Trachsel,H. (1988) The mouse protein synthesis initiation factor $4 \mathrm{~A}$ gene family includes two related functional genes which are differentially expressed. EMBO J., 7, 2097-2105.

21. Yoder-Hill.J., Pause,A., Sonenberg,N. and Merrick,W.C. (1993) The p46 subunit of eukaryotic initiation factor (elF)-4F exchanges with elf-4A. J. Biol. Chemi, 268, 5566-5573.

22. Li,Q., Imataka,H., Morino,S., Rogers,G.W.Jr, Richter-Cook,N.J., Merrick, W. C. and Sonenbery,N. (1999) Eukaryotic translation initiation Mol. Cell. Biol., 19, 7336-7346.

3. Holzmann,K., Gemer,C., Poltl,A., Schafer, R., Obrist,P., Ensinger,C., protein homologous to eukaryotic translation initiation factor $4 \mathrm{~A}$. Biochem. Biophys. Res. Commun., 267, 339-344.

24. Ferraiuolo,M.A., Lee,C.S., Ler,L.W., HsuJ L., Casta-Mattioli,M., Luo,M.J., Reed,R. and Sonenberg,N. (2004) A nuclear translation-like factor elf4AIII is rectuited to the mRNA during splicing and function in nonsense-mediated decay. Proc. Narl Acad. Sci. USA, 101,

25. Chan,C.C., Dostie,J., Diem,M.D., Feng,W., Mann,M., Rappsil ber,J. and Dreyfuss,G. (2004) elF4A3 is a novel component of the exon junction complex. RNA, 10, 200-209.

26. Palacios,I.M., Gatfield,D., St,J.D. and baurralde,E. (2004) An elf4AIII-containing complex required for mR NA localization and nonsense-mediated mRNA decay. Nature, 427, 753-757.

27. Shibuya,T., Tange,T.O., Sonenberg,N. and Moore,M.J. (2004) eIF4AIII binds spliced mRNA in the exon junction complex and is essential for 346-351.

28. Ballut,L, Marchadier,B., Baguet,A., Tomasetto,C., Seraphin,B. and Le,H.H. (2005) The exon junction core complex is locked onto RNA by $861-869$

29. Tange,T.O., Shibuya,T., Jurica,M.S. and Moare,M.J. (2005) Biochemical analysis of the EJC reveals two new factors and a stable tetrameric protein core. $R N A, 11,1869-1883$.

30. Shibuya,T., Tange,T.O., Stroupe,M.E. and Moore,M.J. (2006) Mutational analysis of human eIF4AIII identifies regions necessary for exon junctioncomplex formation and nonsense-mediated mRNA decay. SNA, 12, 360-374.

, Benson,D.R., Bacelar,O., Carvalho,E.M. Kubin,M., Badaro,R., Trinchieri,G. and Reed,S.G. (1995) A recombinant Leishmania antigen that stimulates human peripheral blood mononuclear cells to express a Th1-type cytokine profile and to produce interleukin 12. J. Exp. Med., 181, 1527-1537. 

32. Skeiky,Y.A., Kennedy,M., Kaufman,D., Boryes,M.M., Guderian,J.A.,
Scholler,J.K., Ovendale,PJ., Picha,K.S., Mornissey,P.J., Grabstein,K.H. et al. (1998) LelF: a recombinant Leishunania protein that induces an IL-12-mediated Th1 cytokine profile. J. Inmunal., 161 6171-6179

33. Dhalia,R., Reis,C.R., Freire,E.R., Rocha,P.O., Katz,R., Muniz,J.R. Standart,N. and de Melo Neto, O.P. (2005) Translation initiation i major: characterisation of multiple elF $4 \mathrm{~F}$ subunit

homologues. Mol. Biochem. Parasitol., 140, 23-41.

Wirtz,E. LealS., Ochatt, C, and Cross,G.A. (1999) A tightly regulated inducible expression system for conditional gene knock-outs and dominant-negative gen
Parasital., 99, 89-101.

35. Wickstead,B., Ersfeld,K. and Gull,K. (2002) Taryeting of a tracycline-inducible expression system to the transcriptionally silen minichromosomes of Trypanasoma brucei. Mal. Biachem. Parasitol.

36. Pause,A., Methot,N., Svitkin,Y., Merrick,W.C. and Sonenbery,N. (1994) Dominant negative mutants of mammalian translation initiation factor elF-4A define a critical role for elF-4F in cap-dependent and cap-independ $1205-121.5$

37. Hirumi,H. and Hirumi,K. (1989) Continuous cultivation of Trypanosama bricei blood stream forms in a medium cont ai ning a low concentration of serum protein without feeder cell layers. J. Parasitol.

8. Webb,H., Bums, R., Ellis,L., Kimblin,N. and Carrington,M. (2005 Develpe mR is dependent $1503-1512$.

39. Carrington,M., Roditi.I. and Williams,R.O. (1987) The structure and transcription of an element interspersed between tandem arrays of mini-exon donor RNA genes in Trypanosoma brucei. Nucleic Acids

Res., 15, 10179-10198.
. Minshall, N., Thom,G. and Standart,N. (2001) A conserved role of a DEAD box helicase in mRNA masking. RNA, 7, 1728-1742.

Tordin,O., Taner,N.K., Doce,M., Linder,P. and Banroques,J. (2004) The new discovered Q monif of DEAD-box RNA helicases regulate Tanner,N.K., Cordin,O., Banroques,J., Doere,M. and Linder,P. (2003) The Q motif: a newly identified motif in DEAD bax helicases may regulate ATP binding and hydrolysis. Mol. Cell, 11.
$127-138$.
43. Roditi,I., Carrington,M. and Turner,M. (1987) Expression of a polypeptide containing a dipeptide repeat is confined to the insect stage

of Trypanasoma brucei. Nature, 325, 272-274.
4. von der Haar,T. and McCarthy,J.E. (2002) Intracellular transl ation initiation factor levels in Saccharonyces cerevisiae and their role in cap-complex flantion. Mal. Microbiol, 46, 531-544.

5. Kressler.D. de la,C.J., Rojo,M. and Linder,P. (1997) Fallp is an essential DEAD-box protein involved is US-nbosomal-subun in biogenesis in

46. Cheng,Z., Coller,J., Parker,R. and Song,H. (2005) Crystal structure and

functional analysis of DEAD-box protein Dhhlp. RNA, 11, 1258-1270.

. Oberer,M., Marintchev,A. and Wagner,G. (2005) Structural basis for the enhancement of elF4A helicase activity by elF $4 \mathrm{G}$. Genes Dev., 19,

48. De Gaudenzi,J., Frasch,A.C. and Clayton,C. (2005) RNA-binding

Cell, 4, 2106-21 14 .
49. Mir,G., Shi, H, Li,H. Djikeng,A., Aviles,H.O., Bishop.J.R.

Falcone,F.H., Gavilescu, C Mantgomery J., Santori.M.I., et (2000) A new twist in trypanosome RNA metabolism: cis-splicing of pre-mRNA. RNA, 6, 163-169.

50. Ivens,A.C., Peacock,C.S., Worthey,E.A., Murphy,L, Aggarwal,G.. Berriman,M., Sisk,E, Rajandream,M.A., Adlem,E, Aert,R. et al. (2005) The genome of the kinetoplastid parasite, Leishmania major. Science.

1. Conti,E. and Izaurralde,E. (2005) Nonsense-mediated mRNA decay: molecular insights and mechanistic variations across species. $C u r$.

2. Lejeune,F. and Maquat L.E. (2005) Mechanistic links between nonsense-mediated mRNA decay and pre-mRNA splicing in
mammal ian cells. Curr. Opin. Cell Biol., 17, 309-315.

53. Lejeune,F., khigaki, Y., Li,X. and Maquat,L.E. (2002) The exon unction complex is detected on CBP80-bound but not elF4E-bound .

21, 3536-3545.
4. Ishigaki, Y., Li,X., Serin,G. and Maquat,L.E. (2001) Evidence for a pioneer round of mRNA translation: mRNAs subject to CBP20. Cell, 106, 607-617.

55. Li,H. and Tschudi,C. (2005) Novel and essential subunits in the 300-kilodalton nuclear cap binding complex of Trypanosoma bruces. Mol. Cell Biol., 25, 2216-2226. 